\author{
UNIVERSIDADE DE SÃO PAULO \\ FACULDADE DE FILOSOFIA, LETRAS E CIÊNCIAS HUMANAS \\ DEPARTAMENTO DE ANTROPOLOGIA \\ PROGRAMA DE PÓS-GRADUAÇÃO EM ANTROPOLOGIA SOCIAL
}

PAULO MENOTTI DEL PICCHIA

Por que eles ainda gravam?

Discos e artistas em ação

Versão Corrigida

São Paulo

2013 


\author{
UNIVERSIDADE DE SÃO PAULO \\ FACULDADE DE FILOSOFIA, LETRAS E CIÊNCIAS HUMANAS \\ DEPARTAMENTO DE ANTROPOLOGIA \\ PROGRAMA DE PÓS-GRADUAÇÃO EM ANTROPOLOGIA SOCIAL
}

\title{
Por que eles ainda gravam? \\ Discos e artistas em ação
}

\section{Versão Corrigida}

Paulo Menotti Del Picchia

De Acordo

Dissertação de Mestrado apresentada ao Programa de Pós-Graduação em Antropologia Social do Departamento de Antropologia da Faculdade de Filosofia, Letras e Ciências Humanas da Universidade de São Paulo, para a obtenção do título de Mestre em Antropologia

Orientador: Professora Doutora Rose Satiko Gitirana Hikiji

São Paulo

2013 
Aos meus filhos Maria Júlia Novaes Del Picchia e João Sanches Del Picchia 


\section{RESUMO}

Esta dissertação une antropologia e música para analisar processos contemporâneos de produção de discos e músicos na cidade de São Paulo. A questão central que permeia todo texto é a seguinte: por que ainda se grava discos na era da música digital compartilhada no ciberespaço através da internet? Em outras palavras, por que no mesmo período em que as vendas de discos físicos (CDs e discos de vinil) diminuíram, colocando as grandes companhias fonográficas numa crise sem precedentes, um grupo de compositores urbanos passou a produzir e lançar discos físicos de forma autônoma, contínua e intensa? Acompanhando processos criativos e produtivos de três compositores paulistas - Kiko Dinucci, Rodrigo Campos e Tatá Aeroplano -, o disco emergiu como agente fundamental realizando as mediações que possibilitam aos compositores se constituírem enquanto artistas, construindo uma imagem pública (e uma sonoridade), e conquistando reconhecimento coletivo. O mesmo processo de digitalização que desencadeou a pirataria musical na internet, desencadeou um curto-circuito entre arte e técnica no fazer musical, e um curto-circuito entre artista e público, reconfigurando o lugar social dos discos para esse grupo de compositores que ainda faz questão de gravar e lançar músicas próprias.

No primeiro capítulo, baseado numa etnografia dentro de estúdios, acompanhei a gravação dos discos - Bahia Fantástica (Rodrigo Campos), Tatá Aeroplano (Tatá Aeroplano) e Metal Metal (Kiko Dinucci). Identifiquei dinâmicas coletivas de arranjo das canções que caracterizam um processo criativo no qual as atividades de todos os envolvidos são permeáveis entre si, e em que arte e técnica se interpenetram.

No segundo capítulo, realizei uma experimentação musical com a teoria da agência de Alfred Gell, para analisar como os discos agem fora dos estúdios transformando a vida dos envolvidos em sua produção. Os discos, tratados aqui como indexes musicais, se mostraram sujeitos atuantes nos processos de construção dos artistas.

No terceiro e último capítulo, segui os três compositores na internet mapeando alguns usos e estratégias de ação no ciberespaço. Procurei descrever como os discos são disponibilizados no mundo digital, especialmente em redes sociais que possibilitam uma comunicação direta entre artistas e público. Os três capítulos juntos descrevem como os discos gravam os artistas, tanto quanto os artistas gravam os discos.

palavras-chave: música, disco, agência, curto-circuito, arte, técnica 


\begin{abstract}
This dissertation connect anthropology and music to analyze contemporary process of record production and musicians in São Paulo. The central question that permeates the entire text is the following one: why does it still record albuns in the age of digital music shared on cyberspace through internet? In other words, why at the same time when the physical record sales decreased (CDs and vinyl records), placing large companies in an unprecedented crisis, a group of urban composers is recording and releasing physical records with autonomy, intensity and continuity? Following creative and productive processes of three composers from São Paulo - Kiko Dinucci, Rodrigo Campos e Tatá Aeroplano -, the disc has emerged as a central agent performing the mediations that enable the composers to build themselves as artists, building a public image (and a sonority), and acquiring collective recognition. The same digitalization process that has triggered musical piracy on internet, has triggered a shortcircuit between art and technique in the music making, and a short-circuit between artist and public, reconfiguring the record's social position inside this group of composers that still record and release their songs.
\end{abstract}

In the first chapter, based on an ethnography inside the studios, I followed the recording process of - Bahia Fantástica (Rodrigo Campos), Tatá Aeroplano (Tatá Aeroplano) e Metal Metal (Kiko Dinucci). I have indentified song's collective dynamics of arrangements that characterize a creative process where the activities of all people involved are together permeable, and where art and technique intertwine.

In the second chapter, I have conducted a musical experiment with Alfred Gell's agency theory, to analyze how the records act outside the studios, transforming the social life from the people involved with its production. The records, treated here as musical indexes, have presented it selves as acting subjects in the process of an artist construction.

In the third and last chapter, I have followed the composers, while mapping their uses and strategies of action on cyberspace. I have tried to describe how the records are available in the digital world, especially in social networks enabling a straight communication between artists and public. All the three chapters together describe how the album record the artists, as much as the artists record the albums.

key words: music, record, agency, short-circuit, art, technique 


\section{SUMÁRIO}

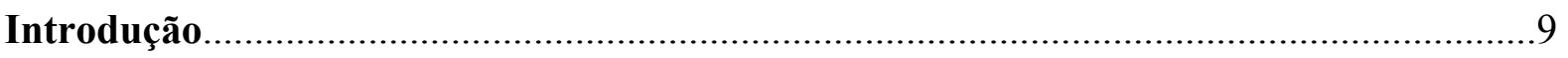

1. Sobre as possibilidades de uma antropologia musical urbana............................................13

2. São Paulo imã de músicos......................................................

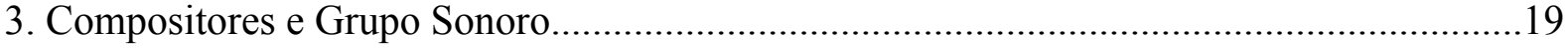

4. Cancionistas, compositores, intérpretes, instrumentistas ou artistas...................23

Capítulo 1 - Da Canção Bruta à Canção Produzida.................................... 32

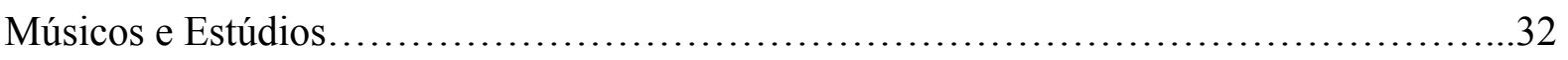

1a Parte - Seguindo os Discos em Construção - etnografia dentro de estúdios

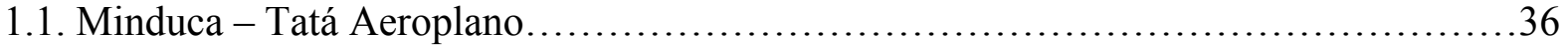

1.2. Intimidade com a tecnologia - produtor musical como mediador entre arte e técnica....42

1.3. Dinâmicas coletivas de arranjo................................................ 51

1.4. Cardeal 2100 - Passo Torto..............................................56

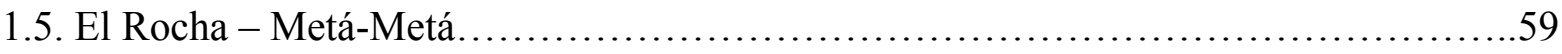

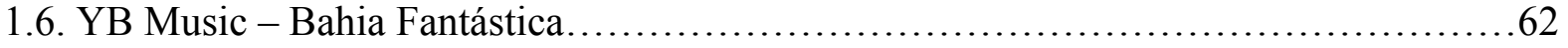

2a Parte - De Casa para o disco - da canção bruta à canção produzida.................66

1.7. Canção bruta................................................................... 67

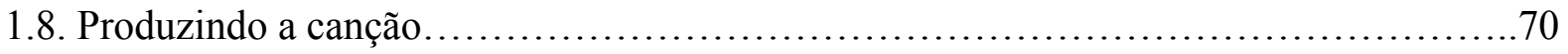

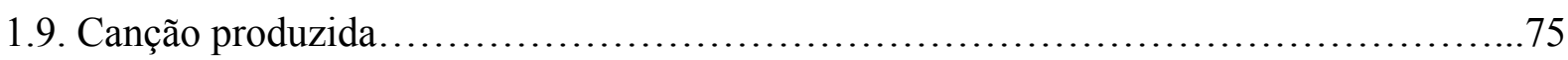

1.10. Curto-circuito entre técnica e arte........................................... 81

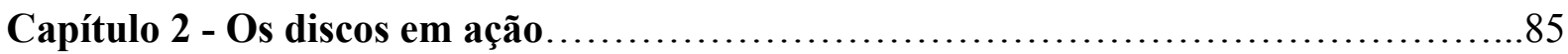

2.1. O fazer musical dos novos compositores....................................... 86

2.2. Discos reconfigurados....................................................... 90

2.3. Rodrigo Campos - São Mateus Não É Um Lugar Assim Tão Longe.....................99

2.4. Teoria da agência e música.................................................. 103

2.5. Indexe musical - sobre a ligação entre artistas e discos............................108

2.6. Tatá Aeroplano e a banda Cérebro Eletrônico - Onda Híbrida Ressonante..............112

2.7. O Segundo disco como indexe paciente.......................................115 
Capítulo 3 - Cibercultura e música: sobre discos virtuais e usos da internet...........130

3.1. Digitalização da música...................................................... 132

3.2. Sociedade em rede e comunicação............................................. 140

3.3. O uso do MySpace........................................................ 146

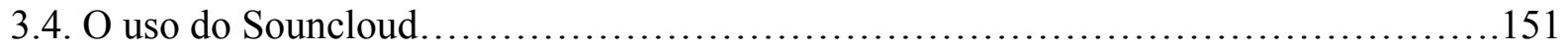

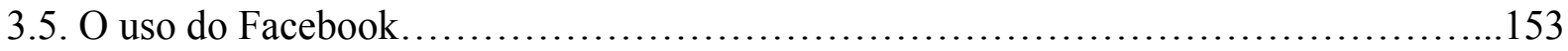

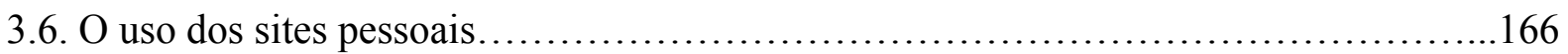

3.7. Curto-circuito comunicacional entre artistas e public.............................170

Considerações Finais............................................................ 174

Nota sobre a ideia de música independente....................................... 177

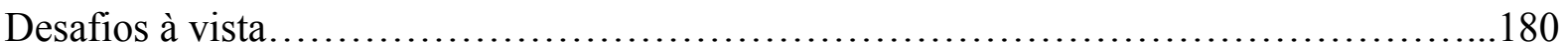

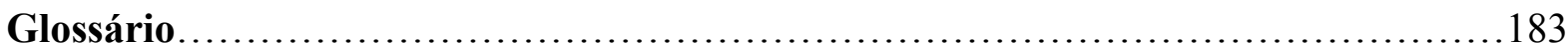

Referências Bibliográficas.................................................... 184

Referências Fonográficas................................................... 191 


\section{INTRODUÇÃO}

Esta dissertação é fruto do encontro de um músico apaixonado por antropologia com um antropólogo apaixonado por música. Meu interesse pela música vem de longe, desde os primórdios da adolescência quando comecei a tocar baixo elétrico e participar de bandas de MPB e de Rock. Nunca parei de tocar, mesmo quando entrei no curso de Ciências Sociais na USP continuei minha trajetória como instrumentista, me tornando aos poucos também um compositor. Ainda na graduação, comecei a ter contato com a área de estudos caracterizada pelo encontro da antropologia com a música - etnomusicologia para uns, antropologia da música para outros - através de dois cursos ministrados por dois professores visitantes na época, um por Kazadi wa Mukuna e o outro por Tiago de Oliveira Pinto. Esses cursos foram de extrema importância para despertar uma serie de questões, sendo que uma delas me acompanhou ao longo dos anos - a ideia de que para se compreender a música de forma mais abrangente é fundamental se falar das relações sociais que envolvem o fazer musical e não apenas de melodias, ritmos e harmonias. As formas, estilos e gêneros musicais variam imensamente pelo globo, entretanto, são sempre fenômenos produzidos através de relações sociais. O pensamento antropológico priorizou ou focalizou, durante muito tempo, as relações entre humanos. Porém, o fazer musical envolve também as relações sociais com não-humanos, sejam eles espíritos, tambores, vitrolas ou computadores.

Falando em não-humanos ligados ao universo musical, ainda tenho em casa uma antiga vitrola Gradiente que ganhei de meu pai aos 11 anos de idade, mais ou menos na mesma época em que comecei a querer tocar instrumentos musicais. Na verdade, ganhei a vitrola um pouco antes de ganhar o meu primeiro violão e ao escrever essas linhas, me ocorreu que talvez a vitrola tenha sido a responsável pelo violão, tenha causado o violão em minha vida. Mas o que causou a vitrola? Com certeza o primeiro disco do Pink Floyd que ouvi em 1989, The Wall, cujos acordes reverberaram anos a fio nos meus ouvidos. Tratava-se de um disco duplo, a capa era o desenho de um muro branco e remetia a muitas coisas, entre elas, ao próprio muro de Berlim que havia sido destruído há pouco tempo. O disco The Wall era tão grandioso que também deu origem a um filme onde a trilha sonora narrava a história. Meu aprendizado musical foi muito marcado pelos discos que chegavam à minha vitrola Gradiente. Quando se está a aprender um instrumento a gente tenta tirar de ouvido as músicas das quais gostamos. 
Em Maio de 2013 fiz uma lista de CDs estrangeiros que gostaria de comprar para uma amiga que viajaria a Miami nos Estados Unidos. Selecionei alguns artistas que admiro bastante e que não encontrava nas lojas de discos brasileiras, ou que quando encontrava o preço era exorbitante. Para minha surpresa e decepção ela retornou da viagem sem nenhum álbum na mala, me contando que todas as lojas de discos de Miami fecharam as portas e que a loja mais próxima do local onde ela se hospedara ficava há uma hora e meia de viagem.

Dia 9 de Junho de 2013, na Ilustrada da Folha de São Paulo, o jornalista Lucas Mobile, especializado em música, assinou a matéria "Músicos elegem CD como melhor formato." Ele entrevistou três músicos de gerações diferentes - o maestro João Carlos Martins, o vocalista de rock Nasi e o rapper Rael - sobre três formatos diferentes, Vinil, CD e MP3. "Aos 72 anos, o maestro foi apresentado pela primeira vez ao formato digital, dominante desde os anos 1990.” João Carlos Martins afirmara que aquela era a primeira vez que escutava a sigla MP3 ${ }^{1}$. Para Rael o MP3 “funcionou por ser fácil de ser compartilhado.” O Rapper seguia dizendo: "não consigo viver sem o MP3, não dá para ter tudo no formato físico, sem desmerecer o CD e o vinil, que têm bastante qualidade."

Estes dois pequenos parágrafos ilustram aspectos curiosos do momento que estamos vivendo na música: de um lado as vendas de discos físicos estão caindo acentuadamente a ponto das lojas de discos se tornarem raras, de outro, músicos de uma geração mais velha acostumados aos CDs e discos de vinil não acompanham os novos formatos e suportes que se multiplicam. Numa mesma época, pessoas que vivem da música, como o maestro João Carlos Martins, sequer haviam escutado falar em MP3, e outras como Rael, não vivem sem o MP3. Estamos diante de múltiplas temporalidades com várias formas de se escutar música gravada coexistindo. Essas temporalidades se expressam, por exemplo, na variedade de aparelhos, suportes e formatos encontrados na música. Mesmo os termos para denominar a música gravada se multiplicam. No primeiro parágrafo, propositalmente, escrevi CDs, discos e álbuns para designar, basicamente, um mesmo tipo de objeto que encomendara para minha amiga. $\mathrm{Na}$ matéria de jornal encontramos a expressão "formato" logo no título para expressar a

\footnotetext{
${ }^{1}$ No decorrer da matéria discute-se a qualidade do áudio nos três formatos a partir da opinião dos músicos submetidos a um "teste cego." Os três escutaram de costas a faixa "You Don't Know Me", do disco Transa, de Caetano Veloso, nos três formatos para tentarem advinhar de qual deles vinha o som.
} 
variedade de "suportes" da música gravada². Mas MP3 é um suporte ou um formato de arquivo? No discurso informal do dia a dia, e até mesmo em textos e publicações de jornal e de blogs encontramos essa proliferação de termos para expressar os objetos que contêm música gravada.

O texto apresentado aqui é resultado de uma etnografia de discos em construção realizada na cidade de São Paulo, entre 2011 e início de 2013, na qual acompanhei os processos de criação musical de três compositores - Rodrigo Campos, Tatá Aeroplano e Kiko Dinucci. Cada um deles produziu e lançou pelo menos um disco, ao longo deste período. Seu fazer musical é marcado por uma produção de discos intensa. Para fornecer uma base teórica para este trabalho de campo utilizei dois grupos de autores da antropologia - de um lado, um grupo que trata da música enquanto fenômeno humano presente nos mais variados povos e regiões do globo, música como objeto de estudo das ciências sociais; e de outro, autores contemporâneos que realizam uma análise crítica do próprio lugar da antropologia enquanto ciência, simetrizando as relações entre humanos e não-humanos, sujeitos e objetos, ocidentais e nãoocidentais. No primeiro grupo, o dos antropólogos que se debruçam sobre a música como chave de estudos, as principais referências são Alan Merriam, Anthony Seeger, Steven Feld e John Blacking. No segundo grupo, trago as contribuições de Alfred Gell e Bruno Latour, dois autores fundamentais para as análises sobre o disco enquanto objeto/sujeito musical.

A questão central que permeia todo texto e amarra os capítulos é a seguinte: por que no mesmo período em que as vendas de disco despencaram e a indústria fonográfica entrou em profunda crise financeira, um grupo de compositores urbanos passou a produzir e lançar discos de forma autônoma, contínua e intensa? Em outras palavras, por que ainda se grava discos na era da música digital compartilhada no ciberespaço através da internet? Diversos estudiosos - Chagas e Pereira de Sá (2011), Machado e Nolasco (2011), Dias (2010; 2012), Herschman (2010; 2011), Perpétuo e Silveira (2009), Lima (2008) - reconhecem a perda da centralidade do disco físico e o aumento do mercado digital de música. É ponto pacífíco que estamos vivendo um período de grandes transformações nos padrões de consumo de música.

\footnotetext{
${ }^{2}$ Para uma discussão inteligente e esclarecedora sobre as diferenças entre "formato" e "suporte" vale conferir o artigo de Márcia Tosta Dias (2012). Pelo que compreendi no artigo, o suporte está ligado às mídias físicas que podem ser $\mathrm{CDs}$, discos de vinil, fitas $\mathrm{K} 7$ etc. $\mathrm{O}$ formato estaria mais ligado à forma e/ou estrutura organizacional das obras musicais. O single, o LP (long play) e o EP (extended play) são exemplos de formato. O single como o próprio nome em inglês indica é o formato onde uma única música é apresentada. O LP se caracteriza pela reunião de 10 músicas em média e é identificado também pela palavra álbum.
} 
"Grandes cadeias de lojas de discos, como Tower Records, fecharam suas portas; lojas de aparelhos eletrônicos e megastores estão diminuindo o espaço de prateleira dos CDs; e distribuidores de música em todos os níveis reequiparam radicalmente suas cadeias de manufatura e fornecimento para distribuir para uma variedade crescente de serviços digitais. Enquanto isso, o modo de consumir mudou, amentando a demanda por singles e abandonando a posse de discos físicos (ou mesmo digitais) em favor de serviços de assinatura e radio via internet." ("The Berkman Center for Internet \& Society at Harvard University” In: Repensando Música. MACHADO; NOLASCO, 2011: 32-34)

Entretanto ele (o disco) persiste em existir, tanto como formato (ou forma musical) quanto como suporte físico. O disco é entendido aqui como as duas coisas juntas, isto é, ele é um formato caracterizado por um determinado número de músicas reunidas, nomeadas e que fazem sentido quando ouvidas juntas ${ }^{3}$. Ele é também um suporte físico onde esse formato de repertório é gravado, sendo que os tipos mais comuns são os CDs e os discos de vinil. Instigado pelas inteligentes provocações de inspiração latouriana do professor Stélio Marras, do Instituto de Estudos Brasileiros da USP, começamos a nos perguntar também: Por que os discos ainda gravam os artistas? Uma pista que essa antropologia simétrica nos forneceu a respeito da permanência do disco no mundo da música digital está ligada a sua capacidade de se comportar como sujeito que age em grandes redes sócio-técnicas, como agente imerso em cadeias de relações com outros inúmeros agentes. O método para responder essas questões, de cunho aparentemente musical e econômico, foi a etnografia dos processos sociais que desembocaram nos discos. Essa etnografia foi composta pela observação dos seguintes momentos: ensaios para shows, ensaios para pré-produção de discos, gravações dentro de estúdios, shows em lugares como as unidades do SESC em São Paulo, shows em casas pequenas como a Casa de Francisca, entrevistas individuais com cada artista, entrevistas com músicos que tocavam com esses artistas, entrevistas com donos de selos de música, entrevista com produtores musicais e convívio intenso com os diversos profissionais envolvidos na fazer musical desse grupo sonoro. Essa metodologia etnográfica forneceu dados que análises macrossociológicas e econômicas não puderam fornecer: a cosmovisão dos artistas a respeito de seu fazer musical revelando a importante agência dos discos em suas vidas.

\footnotetext{
${ }^{3} \mathrm{O}$ disco aqui será entendido como uma palavra similar a álbum quando estiver se referindo ao formato musical. Álbum é esse formato de 10 a 14 canções em média, reunidas juntas. É diferente de single e de EP (Extended Play), formatos com poucas músicas. Para mais detalhes cf. Dias (2012). A escolha pela palavra disco é fruto do discurso dos nossos interlocutores na pesquisa - artistas, músicos, donos de selo e técnicos de estúdio. Eles raramente mencionavam a palavra álbum, todos falavam sempre em discos.
} 
Ao longo dessa introdução, realizarei uma breve discussão sobre as possibilidades de lançar um olhar antropológico para manifestações musicais urbanas numa metrópole como São Paulo, localizando que tipo de música e que tipo de músico estamos investigando aqui. Essa discussão inicial é importante para situar o leitor que não está habituado a estudar música a partir da antropologia, ou que não está habituado a estudar antropologia a partir da música. Rodrigo Campos, Tatá Aeroplano e Kiko Dinucci serão inicialmente apresentados ao lado de uma discussão sobre a noção de "grupo sonoro" desenvolvida por John Blacking (2007). Outra noção importante que aparece nessa introdução para situarmos melhor quem são esses compositores é a de "cancionista", tal qual estabelecida por Luiz Tatit (2004). Em seguida, farei uma apresentação resumida dos três capítulos que constituem o corpo dessa dissertação. Os três capítulos juntos contam a trajetória dos discos desde os momentos de criação dentro de estúdios, passando pelo momento em que os discos já lançados começam a agir na vida dos compositores for a do estúdio, chegando até o momento em que os discos disponibilizados na internet atingem um público mais amplo. Os três capítulos juntos nos informam sobre discos construindo e sendo construídos, agindo e sofrendo agência.

\title{
Sobre as possibilidades de uma antropologia musical urbana ${ }^{4}$
}

\begin{abstract}
"O interesse derradeiro do homem é o próprio homem, e música é parte do que ele faz e parte do que ele estuda sobre si mesmo. Mas igualmente importante é o fato de que música é também comportamento humano, e o etnomusicólogos compartilha ambos com as ciências sociais e as humanidades na busca por um entendimento de porque os homens se comportam da forma como o fazem." (MERRIAM, 1964: 16, tradução minha).
\end{abstract}

De todas as discussões encontradas na intersecção entre antropologia e música, um ponto comum é a ideia de que uma perspectiva antropológica permite uma reflexão sobre música que não se limite aos aspectos sonoros e técnicos. Etnomusicologia, musicologia comparada, antropologia da música ou antropologia musical são expressões diferentes que buscam delimitar um amplo campo do conhecimento humano que estuda fenômenos musicais

\footnotetext{
${ }^{4}$ Me inspiro aqui em "Das Possibilidades de uma Audição da Vida Social, de Rose Satiko Gitirana Hikiji (2006). A autora discute, entre outras coisas, porque a antropologia privilegia tanto o visual deixando a audição de lado. Aqui discutimos um pouco como sair do estudo etnomusical das pequenas comunidades em direção à uma metrópole como São Paulo.
} 
encontrados em diversas culturas e sociedades. Para Alan Merriam (1964), a antropologia da música amplia o conhecimento do que é música ao confrontar as linguagens musicais ocidentais com as linguagens musicais do resto do mundo; esse é um dos principais objetivos e o grande mérito desse campo de estudos. Anthony Seeger (2008) apresenta a etnografia da música como uma abordagem descritiva que vai além do registro escrito dos sons, apontando para o registro escrito de como os sons são concebidos, criados e como influenciam outros processos musicais e sociais, indivíduos e grupos. Etnografia musical é a atividade de escrever sobre a maneira pela qual as pessoas fazem música; não deve se confundir com uma antropologia da música, pois não busca linhas teóricas mais gerais. A antropologia da música é a teorização feita a partir da base de dados coletada na etnografia ${ }^{5}$.

A música popular consumida em grande escala na nossa sociedade é considerada uma forma de arte e ao mesmo tempo um produto do mercado; é resultado de um processo técnico altamente especializado, é uma profissão pra milhões de pessoas no mundo e engloba uma grande cadeia de relações produtivas que movimenta uma grande indústria. Merriam diria que o papel do antropólogo interessado em música é olhar para a música na cultura e na música como cultura. Na cultura ocidental urbana, fazer música, no sentido mais restrito de criar e compor músicas novas, é uma atividade artística exclusiva de especialista ${ }^{6}$. Uma antropologia da música urbana contemporânea poderia investigar, entre outras coisas, o lugar social daqueles considerados especialistas no campo sonoro-musical estabelecendo conexões entre o mundo social e os fenômenos musicais. Steven Feld (1984) levanta seis áreas a serem investigadas para estabelecermos relações entre o que ele chama de campo sonoro-musical e o campo social: Competências (quem pode fazer música), Forma (quais os meios musicais materiais e como são organizados em códigos reconhecidos), Performance (relação entre os produtores de música e os materiais), Ambiente, Valor e Igualdade, e Teoria. Essas áreas são levantadas para a investigação em sociedades de pequena escala. Nosso desafio é tecer uma reflexão paralela, levando em conta as considerações levantadas por esses autores, tendo como campo os fazeres musicais na cidade de São Paulo ${ }^{7}$. O tipo de fazer musical que

\footnotetext{
${ }^{5}$ Lomax (2008) criou um método chamado Cantometria para utilizar dados de etnografias musicais coletados em diversas partes do mundo em estudos comparativos.

${ }^{6}$ Para uma rica descrição histórica de processos sociais e econômicos que levaram ao surgimento de especialistas em música nas grandes cidades cf Tinhorão (2011).

${ }^{7}$ Finnegam (2008) é um exemplo interessante de etnografia musical urbana. Ela argumenta, tendo como campo uma cidade inglesa mediana próxima a Londres, que as atividades musicais urbanas são caracterizadas por percursos que não são nem totalmente comunitários no sentido tradicional de comunidade coesa, e nem totalmente alienados no sentido de vida urbana impessoal e fragmentária.
} 
estamos analisando aqui é fortemente ligado à produção de discos. Seeger, Blacking e Merriam considerariam uma ilusão olhar para discos porque captam somente os aspectos acústicos da música. Entretanto, considero que nosso trabalho aqui é justamente captar o que os discos apresentam além dos aspectos acústicos. Concordo com Shouten e Cirino (2005) que apostam na importância do disco no fazer musical contemporâneo ${ }^{8}$.

"Indagamos se não seria possível tratar esta ilusão auditiva produzida pelos meios técnicos como constituinte do fazer musical contemporâneo, tentando trazer os discos para o foco central do empreendimento etnográfico." (SCHOUTEN; CIRINO, 2005: 102).

\section{São Paulo: ímã de músicos}

Numa grande metrópole, a música é um elemento tão comum em nosso cotidiano que é raro nos questionarmos a respeito de onde ela realmente vem num sentido mais profundo: como ela é feita e produzida, quem está por trás de sua veiculação, porque ela tem determinada duração, porque alguns instrumentos são preferidos em detrimento de outros, porque nem todas as músicas tocam no rádio ou na TV, e assim por diante. Ela está presente em bares, casas de show, festas, casamentos, academias de ginástica, escolas, eventos corporativos de grandes empresas, na nossa casa, nas trilhas de filmes, na TV, nas propagandas, nos aparelhos individuais de reprodução sonora (IPods, celulares e tocadores de MP3), até mesmo nos supermercados onde fazemos nossas compras diárias.

"Em público, normalmente é emitida, como parte do ar condicionado, em lojas, salas de espera e elevadores. Em trens e ônibus, frequentemente, passa através dos headphones de outras pessoas. É como se todos, inclusive analistas, 'soubessem' intuitivamente que música é socialmente significativa, embora tentativas de especificar como isso se dá permaneçam fragmentárias e especulativas.” (DEMORA, 2011: 298).

Os formatos dos botões de play se multiplicam, ou seja, os aparelhos reprodutores, suportes e formatos musicais também são encontrados em diversas opções. Essa realidade do mundo urbano contemporâneo é totalmente diversa do que Seeger apresenta sobre os Suyá, ou do que Feld apresenta sobre os Kaluli, povos em que a música emerge como uma atividade coletiva

\footnotetext{
${ }^{8}$ Shouten e Cirino (2005) tentam pensar o disco a partir da noção de inconsciente óptico de Walter Benjamin. Eles falam em inconsciente auditivo para analisar as diferenças entre o ouvido e os novos aparelhos de reprodução sonora. Apesar de ser uma análise bastante diferente da que buscamos aqui, para esses autores o disco é considerado também uma peça fundamental do fazer musical.
} 
diária realizada pela grande maioria das pessoas, sem especialistas e sem distinção entre quem é músico ou não-músico. Pelo menos foi dessa forma que essas duas clássicas etnografias musicais, realizadas na década de 70 do século passado, trataram a música. Mesmo sem falar especificamente da música, Antônio Cândido ([1965] 2006) é fundamental para refletirmos sobre o lugar social dos artistas em diferentes sociedades. Ele fala em sociedades primitivas ou grupos rústicos onde quase não há diferenciação entre quem é artista e quem não é.

"No que se refere às sociedades primitivas, ou aos grupos rústicos, ainda à margem da escrita e das modernas técnicas de comunicação, é menos nítida a separação entre o artista e os receptores, não se podendo falar muitas vezes num público propriamente dito, em sentido corrente. O pequeno número de componentes da comunidade e o entrosamento íntimo das manifestações artísticas com os demais aspectos da vida social dão lugar seja a uma participação de todos na execução de um canto ou dança, seja à intervenção dum número maior de artistas, seja a uma tal conformidade do artista aos padrões e expectativas, que mal chega a se distinguir." (CÂNDIDO, [1965] 2006: 44)

Numa grande metrópole, na maior parte das vezes, a música chega aos nossos ouvidos pela reprodução eletrônica de computadores, Após, aparelhos toca CDs, rádios, televisores etc. Vivemos num ambiente sonoro super estimulado em termos musicais, mas onde predominam as situações em que ouvimos música gravada, ao invés da música tocada ao vivo. Mas quem são e como vivem alguns dos responsáveis pelas emissões sonoras dos nossos aparelhos eletrônicos de reprodução musical?

São Paulo pode ser pensada como a expressão máxima, no Brasil, de uma sociedade altamente especializada onde a música, como tantas outras áreas artísticas, se tornou uma profissão, uma atividade rentável para milhares de indivíduos. As formas de se apropriar da música como uma atividade profissional podem variar muito, encontramos hoje diversos perfis de músico profissional. Temos os músicos de orquestra com formação erudita, temos os músicos de jazz e música instrumental popular brasileira, temos os músicos que atuam somente como professores e /ou docentes em escolas e universidades, temos os músicos que produzem trilhas e jingles para $\mathrm{TV}$, cinema e publicidade, temos os músicos de bailes de casamento, músicos gospel, entre outras inúmeras possibilidades de se trabalhar com música. Existem também músicos capazes de transitar entre diversas áreas, vão do popular ao erudito, do jazz ao pop, dos estúdios de gravação às salas de concerto. Sobre essa variedade de perfis, Campos (2007) nos traz um estudo sociológico onde tenta classificar diferentes modos de relação com a música por parte de músicos profissionais. Cirino (2009) detalha aspectos 
importantes do fazer musical de instrumentistas, compositores e arranjadores no universo da música popular instrumental brasileira.

As inovações tecnológicas na área do áudio amplificaram e, num certo sentido, democratizaram as possibilidades de produção musical para todo esse universo de profissionais. Os principais softwares de gravação, como o Pro-Tools e o Logic, são relativamente baratos, assim como as interfaces e computadores necessários num estúdio. Dentre os diversos tipos de músicos relacionados acima, a maioria já está familiarizada com os chamados home studios, estúdios caseiros espalhados por toda cidade. Se você possui um computador, uma placa de áudio e um microfone já pode se considerar proprietário de um home studio. O músico que não possui esses equipamentos básicos, provavelmente tem algum colega que possui. Esse universo variado de profissionais que vivem da música compartilha entre si essa nova realidade sócio-técnica caracterizada pela acentuada distribuição de estúdios de pequeno e médio porte.

"Hoje, é possível produzir gravações de nível profissional usando apenas um IPad e seu aplicativo GarageBand, em um custo total de 505 dólares. O advento de ferramentas de gravação baratas e canais de auto distribuição levou alguns artistas a evitar produtores, estúdios e selos. Talvez haja menos profissionais de gravação, mas qualquer um pode gravar. Ainda mais: podem remixar." ("The Berkman Center for Internet \& Society at Harvard University" In: Repensando Música. MACHADO; NOLASCO, 2011: 14).

Nesse contexto, existe um grupo de músicos familiarizados com as novas tecnologias de gravação e que se apropriam delas com um objetivo comum - produzir um conteúdo sonoro novo. Eles são os músicos que criam ${ }^{9}$, ou seja, os músicos que compõem obras originais para produzirem discos autorais. Discos autorais são discos de autor, ou seja, são discos nos quais o repertório gravado é constituído por músicas inéditas compostas pelo próprio intérprete. Dentre esses músicos-compositores-intérpretes, existe um grupo residente na cidade de São Paulo que produz um tipo específico de música; produz canções populares, ou como diria Luiz Tatit, encaixam melodia e letra. Poderíamos chamá-los de cancionistas contemporâneos? Veremos que a atividade desses jovens cancionistas é mais ampla e diversificada do que a dos cancionistas do século passado. O próprio Tatit apresenta um pista interessante que pode nos

\footnotetext{
${ }^{9}$ Faz sentido falar em músicos que criam porque encontramos muitos músicos que somente executam o que outros criaram. Os famosos músicos de baile, por exemplo, são especializados em animar festas de casamento tocando repertórios que outros criaram. Músicos de orquestra são outro exemplo de músicos especializados em executar a obra dos grandes compositores ocidentais, entre outras coisas.
} 
ajudar a compreender quem são essas pessoas que produzem música autoral, nesse início de século XXI. Ele afirma que, já no século XX, “ a canção brasileira converteu-se em território livre, muito frequentado por artistas híbridos que não se consideravam nem músicos, nem poetas, nem cantores, mas um pouco de tudo isso e mais alguma coisa." (TATIT, 2004:12).

Rodrigo Campos, Tatá Aeroplano e Kiko Dinucci são representantes contemporâneos desse tipo de artista híbrido que Tatit já encontrara no século XÁ. Seu fazer musical envolve múltiplas habilidades (muitas delas extramusicais) sendo que um objetivo fundamental e compartilhado por todos é a necessidade de se gravar discos com músicas próprias. Se no início do "século da canção" (TATIT, Ibidem) esse fazer musical urbano era dividido entre diversos tipos de atividade (composição, interpretação, gravação, veiculação etc.), vivemos um momento inédito em que muitos artistas híbridos centralizam todo processo de produção musical (eles compõem, interpretam, gravam, desenham as capas dos discos, fotografam, veiculam suas músicas, vendem seus discos etc.). Mesmo desenvolvendo um trabalho multifacetado que envolve outras linguagens artísticas e outros tipos de conhecimento, o objetivo fundamental dessas pessoas é poder produzir música. Como me disse Rodrigo Campos: "A gente acaba fazendo de tudo por necessidade, mas o ideal seria só tocar!"

A cidade de São Paulo, atrai uma enorme quantidade de músicos do Brasil inteiro. Todos os tipos de músicos encontram trabalho na cidade, especialmente esse tipo de músico que estamos investigando aqui, esse músico que é um "artista híbrido" com autonomia sobre todo seu processo criativo e cujo sentido do fazer musical se completa na gravação de discos. São Paulo é a cidade que mais oferece lugares para se tocar música autoral, oferece uma grande rede de pequenos e médios estúdios onde esses artistas podem ensaiar e gravar, oferece os instrumentistas necessários para a formação de bandas e oferece público. Nosso olhar neste trabalho está voltado para o fazer musical de compositores residentes em São Paulo que utilizam novas tecnologias de produção, de divulgação e de distribuição musical para estabelecerem carreiras artísticas nas quais buscam viver de suas criações musicais. Rodrigo Campos, Kiko Dinucci e Tatá Aeroplano são especialistas na arte de compor canções originais e de inscrevê-las em discos. 


\section{Compositores e Grupo Sonoro}

"Um "grupo sonoro" é um grupo de pessoas que compartilha uma linguagem musical comum, junto com ideias comuns sobre a música e seus usos. A pertença aos grupos sonoros pode coincidir com a distribuição das linguagens verbais e das culturas, ou pode transcendê-las, como em partes da Europa e nas Terras Altas de Papua Nova Guiné. Numa mesma sociedade, as diferentes classes sociais podem ser distinguidas como grupos sonoros distintos, ou podem pertencer ao mesmo grupo sonoro, embora estejam profundamente divididas em outras circunstâncias.” (BANKING, 2007:208).

Essa noção de grupo sonoro foi desenvolvida por John Blacking (2007), em "Música, Cultura e Experiência", tornando possível uma unidade básica de análise que não dependa das noções de cultura, sociedade ou comunidade. Ao invés de se debruçar sobre uma cultura, sobre grupos e/ou classes sociais, sobre compositores individuais, a análise cultural que Blacking nos propõe permite recortarmos grupos sonoros no complexo tecido social paulistano. Esses grupos sonoros não precisam coincidir com classes sociais, com etnias específicas, nem mesmo com uma língua comum. Um grupo sonoro é formado por pessoas que compartilham uma linguagem musical comum, lembrando que para Blacking a linguagem musical é formada por dois tipos de discurso, os verbais e os não-verbais. Neste trabalho, considero Rodrigo Campos, Tatá Aeroplano e Kiko Dinucci representantes de um grupo sonoro urbano formado por todos os jovens compositores de canção popular cujo fazer musical está calcado na gravação de discos autorais. Esse grupo sonoro está contido num grupo sonoro mais amplo formado por todos os compositores que gravam discos, incluindo aqui os compositores de música instrumental popular e erudita. Por sua vez, esse grupo sonoro de todos os compositores que gravam discos está contido no grupo mais amplo ainda, formado por todos os músicos compositores, incluindo os que nunca gravaram discos. Podemos diagramar esses grupos sonoros da seguinte forma:

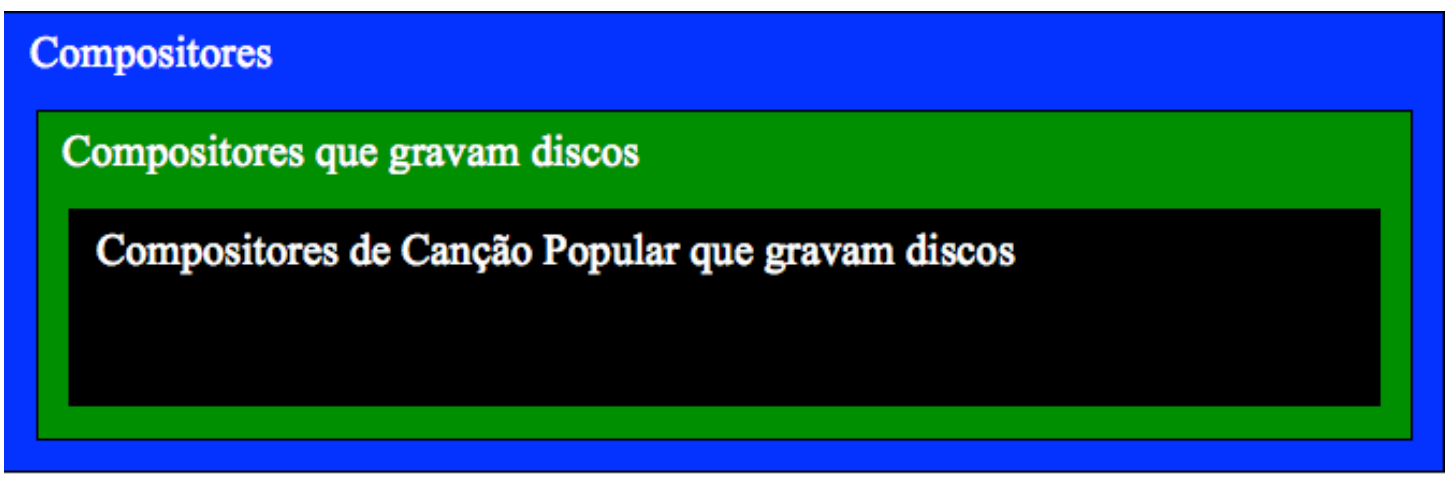

Vale ressaltar que a identificação desses compositores dentro de um grupo sonoro é um 
recurso analítico meu, não é um dado que eles me forneceram discursivamente durante a etnografia - é uma construção minha a partir de uma ideia desenvolvida por Blacking. A produção de discos com canções compostas pelos próprios intérpretes é um traço marcante desse grupo sonoro analisado aqui. O sentido do fazer musical de Rodrigo Campos, por exemplo, está intimamente ligado à composição de repertórios inéditos visando a gravação de discos. Para esclarecer possíveis dúvidas vale dizer que nem todo disco é autoral. Como já mencionei antes, autoral é o disco de autor, ou seja, é quando o repertório gravado é formado por composições inéditas feitas pelas pessoas que realizam o disco.

"Em 2009, Rodrigo Campos, 35, estreou com "São Mateus Não É Um Lugar Assim Tão Longe", um dos melhores álbuns daquele ano, em que se mostrava um cronista singular da periferia de São Paulo. As músicas contavam histórias cotidianas, desenhando personagens complexos para além do estereótipo "mundo cão" de violência, de malandragem e de crime. Esses conflitos ficavam nas entrelinhas enquanto a narrativa principal tratava de figuras humanas: Lúcia, que "vai lecionar na Vila Prudente buscando presente pra aliviar sua dor"; Neném, motorista da "lotação mágica que quase flutua no asfalto da av. Aricanduva"; Isac, que "não sabe se a dor que tem é sua ou de outro alguém".

"Bahia Fantástica", o novo álbum de Rodrigo, parte dos mesmos preceitos." (Trecho da entrevista assinada por Marcus Preto publicada na Folha online, extraído do site: http://m.folha.uol.com.br/ilustrada/1074187-rodrigo-campos-reinventa-a-bahia-emcd.html dia 18/06/2012 `as 15:50 horas. Grifos meus.)

Rodrigo Campos, nascido em Conchas e criado no bairro de São Mateus em São Paulo, chegou a cursar uma faculdade de direito, até resolver largar tudo para se dedicar somente à música. Ele conta que começou a tocar de brincadeira.

"Tem até uma música minha que chama "Cavaquinho" que fala um pouco disso... Que a gente brincava na construção que estava construindo uma escola na época, brincava na areia, ficava pulando na areia, jogava bola, peão e fazia samba, né! fazer samba nessa música é na conotação de brincadeira, brincar de fazer samba...” (Entrevista com Rodrigo Campos, dia 20/05/2011).

Depois desse início brincando, ele teve aulas particulares de cavaquinho quando era mais jovem, e estudou na Fundação das Artes de São Caetano. É um compositor identificado como representante da nova geração do samba paulistano apesar de não se considerar um compositor de samba. Até 2009, Rodrigo atuava como instrumentista, ou seja, o músico que acompanha outros artistas. A partir da gravação de seu primeiro disco, passou a se identificar 
como compositor, como intérprete e como artista. Podemos começar a caracterizar o artista como aquele que busca criar e divulgar algo original. Compor uma música é um outro aprendizado, diferente do aprendizado de um instrumento.

"Eu sempre compus, desde que eu comecei a tocar cavaquinho, eu passei por várias fases como compositor, assim aprendendo a compor né! Desde você copiar o que você gosta, aí no começo eu compunha só samba, aí eu comecei a descobrir outras coisas Chico Buarque, Tom Jobim, Ginga. Eu comecei a procurar esses caminhos também, até tenho uns sambas gravados pelo quinteto em branco e preto nessa época que eu compunha mais samba e tal..." (Entrevista com Rodrigo Campos, dia 20/05/2011).

O disco de estreia trouxe um repertório já amadurecido e obteve reconhecimento justamente por mostrar um trabalho original e de forte personalidade. Os recursos financeiros para este primeiro disco foram fruto de um projeto que o próprio Rodrigo Campos escreveu para captar patrocínio via Lei Rouanet. A produção do segundo disco foi resultado direto do sucesso alcançado pelo primeiro. O fazer musical de Rodrigo Campos passa por um processo múltiplo que envolve, entre outras coisas, estudo do instrumento, composição, letra (crônicas e poesias sobre sua vida na periferia), arranjos, a viabilização econômica das gravações (por exemplo, escrevendo um projeto para Lei Rouanet) e divulgação dos discos.

Lidar com um processo múltiplo como esse é algo compartilhado em grande parte pelo compositor Tatá Aeroplano, 37, líder da banda Cérebro Eletrônico. Ele é o principal compositor dessa banda formada no início dos anos dois mil e com três discos lançados. Ser o principal compositor de uma banda, nesse caso, implica também ser a força motriz que gera os novos projetos de discos e os recursos para esses projetos. Tatá, nasceu em São Paulo, mas foi criado na cidade de Bragança Paulista no interior do Estado. Se formou em comunicação pela FAAP, chegou a trabalhar em agências de publicidade e na SUF. (Universidade São Francisco), mas sempre foi um apaixonado por música. Seu aprendizado musical se deu ouvindo muitos discos; ele nunca teve um estudo formal de música. Já o ouvi dizer que não gosta de "racionalizar muito sobre música para não perder o instinto, a espontaneidade na hora de compor." Vale notar que Tatá, sendo um profundo conhecedor de discos, se tornou um dos DJs mais requisitados da noite paulistana. Ele tinha suas noites fixas no Studio SP, uma das principais casas de show da cidade que encerrou suas atividades em Maio de 2013. Em 2012, Tatá Aeroplano lançou seu primeiro disco solo, o primeiro disco sem a participação 
da banda Cérebro Eletrônico, obtendo uma boa recepção da crítica especializada em música.

“Tatá Aeroplano é ótimo compositor. Suas canções, crônicas cinematográficas de tipos e cenas urbanas, revelam um mundo doce, mas não ingênuo.

Com candura, mas acidez, suas composições buscam o casual, o momentâneo, retratos de figuras baratinadas, sem vergonhas, em momentos de desbunde, de entrega, de risco. Depois de dois discos com o Jumbo Elektro e três com o Cérebro Eletrônico -além de incontáveis bandas e projetos nos últimos anos - neste primeiro álbum assinado com seu nome, Tatá aponta o foco para as canções.

A levada rock com tons de folk e psicodelia segue a essência instintiva e pessoal das faixas, que se apresentam de modo simples e direto, visões afetivas da cidade, entre trânsitos e portas de cinema, poetas beatnik e artistas embalados a pó, tapas e beijos na rua Augusta." (Matéria assinada por Ronaldo Evangelista publicada na Ilustrada da Folha de São Paulo, dia 08/08/2012. Grifos meus.).

Vemos que Tatá Aeroplano já conta com uma boa experiência na produção de discos - além deste disco solo lançado em 2012 e dos três discos lançados com o Cérebro Eletrônico, ele lançou dois discos com a banda Jumbo Elektro. Nenhum destes discos foi feito com apoio de leis de incentivo à cultura. Tatá conta que a maior parte dos recursos financeiros vem de um "caixinha" das bandas, ou seja, economias geradas a partir dos cachês de shows. Chamamos a atenção do leitor para as palavras que grifamos em itálico na matéria revelando sujeitos nãohumanos nas frases. São as canções que revelam um mundo, são as faixas que apresentam visões afetivas da cidade, e não o compositor. Mesmo na matéria que fala de Rodrigo Campos, o jornalista escreve que as músicas contavam histórias cotidianas. Essa agência das obras de arte (GELL, 1998), e/ou essa ação dos não-humanos (LATOUR, 2001) será discutida ao longo dos três capítulos que formam essa dissertação.

Kiko Dinucci é outro representante dessa geração cujo fazer musical se baseia na gravação de discos e na composição de repertórios inéditos. Natural de Guarulhos, Kiko Dinucci, 36, transita por diversas linguagens artísticas. Ele é compositor, é instrumentista, é intérprete, é um artista plástico especializado em gravuras e já trabalhou com cinema dirigindo o documentário "Dança das Cabaças". Assim como Rodrigo Campos e Tatá Aeroplano, Kiko Dinucci domina todas as etapas da produção de sua música. Seja com recurso próprio ou com apoio de leis de incentivo à cultura, ele não para de gravar discos. Já lançou oito discos, sendo que quatro deles aconteceram no período em que eu realizava a etnografia, o Passo Torto, o Metá-Metá, o Passo Elétrico e o Metal Metal. Para vários destes seus oito discos Kiko Dinucci elaborou a arte da capa, normalmente feita com suas gravuras. Comentando em entrevista sobre o processo de produção do disco Passo Torto ele disse o seguinte: 
"Eu fiz a gravura num dia, a capa no outro e no outro a gente já mandou pra fábrica. Foi um negócio corrido assim... E pra mim, eu tenho muita coisa pra mostrar, eu sinto como se fosse um aborto você ter uma ideia e depois ficar "ah, meu disco vai ser assim!" e de repente daqui a 3 meses sua vida muda e você já esqueceu toda aquela ideia. Olha pra trás e fala "puxa se naquela época com a coisa fervendo eu tivesse botado tudo pra fora, pelo menos gravasse." Eu acho que tem que gravar! Por exemplo, eu tenho um disco com o Thiago França gravado. A gente nunca lançou, vamos lançar talvez mês que vem. Um disco de improviso livre, experimental ao extremo, mas é um disco. A gente entrou uma tarde num estúdio e gravou. É o mesmo tema tocado três vezes de formas diferentes. Gravou, entendeu? A gente gravou isso o ano passado ou dois anos atrás, sei lá! E vamos lançar só agora. Gravou e isso é o que importa, foi registrado isso, não se perdeu! Mesmo que você não lance um disco agora você tem que registrar suas ideias." (Entrevista com Kiko Dinucci, dia 22/04/2012. Grifos meus.).

Essa fala revela entre outras coisas a intensidade da energia criativa de Kiko Dinucci e como o processo de entrar em estúdio para gravar suas ideias musicais é extremamente valorizado. Uma curiosidade sobre Kiko Dinucci é que nenhum de seus discos é considerado um disco solo, são discos realizados com bandas, trios e duos, feitos e assinados sempre em parceria. Ele é considerado por muitos jornalistas e especialistas em música popular como um dos herdeiros de Adoniran Barbosa, Geraldo Filme e Paulo Vanzolini. Perguntei como se identificava profissionalmente, ele respondeu que gostaria muito de poder dizer "artista", mas que acaba se identificando como "músico" porque existe um estereótipo na sociedade de que o artista é uma figura "sonhadora, alienada, maluco na". Como identificar esses jovens músicos-compositores que acabam fazendo muito mais do que tocar e compor?

\section{Cancionistas, compositores, intérpretes, instrumentistas ou artistas?}

Luiz Tatit (2004) argumenta que a primeira leva de cancionistas brasileiros surgiu no início do século $\mathrm{XX}$, com os improvisadores de samba que cantavam nos fundos da casa de Tia Ciata. Esses sambistas retiravam suas letras da fala cotidiana e as encaixavam em melodias improvisadas, acompanhadas pelo batuque dos terreiros e pelo violão. Os improvisos rapidamente se perdiam, assim como a fala. "Portanto, o encontro dos sambistas com o gramofone mudou a história da música brasileira e deu início ao que hoje conhecemos como 
canção popular." (TATIT, 2004:35). Esse encontrou possibilitou o registro das melodias e letras de compositores sem formação musical erudita.

"Todos esses sambas já produzidos para gravação em disco nessa primeira fase que se estenderia de 1917 a 1927 - ano que marca o fim das gravações mecânicas e o advento do sistema elétrico - guardam entre eles a marca sonora do seu parentesco com os sambas do partido alto dos baianos, que soavam ainda como eco de suas origens rurais no Recôncavo.” (TINHORÃO, 1998: 291).

José Ramos Tinhorão (1998) fornece uma linha histórica que nos permite visualizar a indústria fonográfica no Brasil se iniciando com esses sambistas nos anos 1910-20, e se transformando ao longo do século. Segundo Tinhorão, o período logo após a 2a Guerramundial é marcado por uma valorização da música norte-americana e por um crescimento do mercado fonográfico reflexo, entre outras coisas, da euforia econômica pós-guerra. Os nossos cancionistas começam a metabolizar o jazz nos anos 50 forjando, no fim dessa década, a bossa-nova. A bossa-nova teve como seu grande representante um grande intérprete - João Gilberto - que ficou famoso por suas interpretações de músicas de outros compositores, tendo inclusive regravado muitos sambas antigos. Seu disco Chega de Saudade, lançado em 1959, é considerado por muitos o grande marco estético da bossa-nova.

Analisando canções urbanas, Santuza Cambraia Naves (2012) indica outro exemplo de como um disco pode ser agente na constituição de um estilo. No início dos anos 60, Nara Leão gravou Nara, um disco que mistura as influências da bossa-nova a canções de teor político. Segundo a autora, esse discos trouxe canções:

“[...] paradigmáticas para a caracterização da chamada música de protesto que se criou no Brasil à época. Há quem atribua a este disco, pelas novidades temáticas e musicais nele introduzidas, que o distinguem das músicas da bossa-nova, a preeminência na criação de um estilo que passaria, a partir de meados da década de 60 , a ser chamado de MPB.” (NAVES: 2012: 57)

Em seguida, o rock americano também é metabolizado culminando no tropicalismo e na jovem guarda ao longo da década de 60. Esse período é marcado pelo surgimento na cena musical de grandes cancionistas como Chico Buarque, Gilberto Gil e Caetano Veloso que se consolidaram como artistas nobres da MPB. Esses nomes são exemplos de cancionistas que são também grandes intérpretes de suas próprias canções. Nos anos 80 , vemos o surgimento de uma cena de rock nacional muito forte com nomes como Legião Urbana, Titãs e Paralamas 
do Sucesso alcançando sucesso de público e de venda de discos. Logicamente, estou fazendo um voo rasante na velocidade da luz sobre esses anos que foram intensos e riquíssimos em termos de produção musical, simplesmente para fornecer um panorama geral dos movimentos musicais dos cancionistas brasileiros que constituíram o casting nacional da indústria fonográfica ao longo do século XX.

No início do século XXI, com o barateamento das tecnologias de gravação e com a proliferação dos home studios entramos numa nova fase desse encontro centenário dos cancionistas com as gravações sonoras. Vimos que o gramofone tornou possível o registro dos sambistas que não sabiam escrever partitura. Tornou duradouro o que antes era frágil e se perdia no tempo. Agora, um século depois, observamos junto ao grupo sonoro analisado aqui que não é tão importante escrever partitura, já que gravar se tornou bem mais fácil. É muito mais valorizado, operar um software de gravação como o Logic ou o ProTools, do que escrever um arranjo na partitura. Os arranjos para os discos do Tatá Aeroplano, por exemplo, foram feitos coletivamente pelos músicos da banda e eram gravados na medida em que iam surgindo. Ninguém escrevia uma nota, Tatá começava a cantar e os outros começavam automaticamente a tocar seus instrumentos sugerindo ideias musicais no calor do momento. Situação similar ao que Rodrigo Campos e Kiko Dinucci experimentaram na produção de seus últimos discos, o que implica num jeito de compor e arranjar bem específico que merece ser detalhado.

O cancionista não é necessariamente um músico com formação técnica, não precisa ser um virtuose do instrumento. Segundo Kiko Dinucci, é até melhor que não o seja, pois em sua opinião os instrumentistas virtuoses normalmente são "alienados". Para ele, o que diferencia um artista de um músico, é que o artista seria menos alienado e mais conectado com as coisas que acontecem no mundo. O músico só fala de música e só pensa em música. $O$ artista deveria pensar no mundo e falar do mundo. Kiko, Rodrigo e Tatá falam do mundo através de canções, porém seu fazer musical não se resume a encaixar letra e melodia. Tatit identifica o cancionista brasileiro com a figura do malabarista, um malabarista que equilibra a flexibilidade da fala com a estabilização do canto ${ }^{10}$. Ao longo do século XX, esses

\footnotetext{
10 "O cancionista mais parece um malabarista. Tem um controle de atividade que permite equilibrar a melodia no texto e o texto na melodia, distraidamente, como se para isso não despendesse qualquer esforço. Só habilidade, manha e improviso. Apenas malabarismo. Cantar é uma gestualidade oral, ao mesmo tempo contínua, articulada, tensa e natural, que exige permanente equilíbrio entre os elementos melódicos, linguísticos, os parâmetros musicais e a entoação coloquial.” (TATIT, 2002:9).
} 
malabaristas da fala e do canto se tornavam artistas conhecidos na medida em que eram gravados, em que se tornavam compositores contratados de grandes Cias fonográficas e tinham seus discos lançados no mercado. Numa certa perspectiva, os discos criam os artistas na medida em que transformam um músico ou compositor ou cancionista desconhecido em figuras reconhecidas por um grande público. Essa ação dos discos será explorada com mais atenção no primeiro e no segundo capítulos.

Os três artistas em questão aqui poderiam também ser pensados como malabaristas do canto e da fala. Porém, esse malabarismo é muito mais amplo do que o malabarismo dos cancionistas que Tatit analisou. Os artistas de hoje são também malabaristas das técnicas de gravação, das técnicas de captação de recursos (sejam leis de incentivo à cultura ou os chamados crowdfunding $^{l 1}$ ), de execução dos instrumentos, da divulgação de suas obras na internet, das leis de direitos autorais etc. Eles se equilibram entre a necessidade pessoal que sentem de lançarem discos e a crise global na venda de discos, entre sua atuação como instrumentistas ao lado de outros artistas e sua atuação como compositores-intérpretes que se tornam artistas, entre a falta de recursos próprios para o lançamento de seus discos e os editais de incentivo à cultura, entre os arranjos escritos na partitura e as dinâmicas coletivas de criação musical.

Os cancionistas do início do século XX eram uma mistura de músicos, poetas, compositores e intérpretes. Porém, com o desenvolvimento do mercado fonográfico, essas funções se tornaram cada vez mais separadas e especializadas. Tatit (2004) já fornece indícios da separação, desde as primeiras gravações, entre compositor e intérprete. O samba "Pelo Telefone", um dos primeiros hits da música popular brasileira gravado em 1916, foi registrado por Donga, teve sua primeira interpretação feita por Bahiano e foi lançado pela gravadora Odeon. Rita Morelli ([1991] 2009) e Marcia Tosta Dias (2008) deixam claro como, entre os anos 1970-80, a indústria fonográfica era formada por profissionais altamente especializados reflexo da divisão social do trabalho nas economias capitalistas. O músico

${ }^{11}$ Crowdfunding corresponde a uma nova prática de financiamento coletivo de projetos dos mais variados tipos através da internet. São sites criados para apresentar projetos em busca de financiamento. Tatá Aeroplano fez um crowdfunding para o lançamento de seu mais recente disco e conseguiu captar o dinheiro que precisava. $\mathrm{Na}$ época em que ele estava captando esse financiamento, recebi o seguinte e-mail: "Amigos, Estou gravando meu primeiro trabalho solo, com produção de Dustan Gallas e Junior Boca, e para bancar todos os custos do disco, estou participando do embolacha.com, que é um sistema crowdfunding, onde as pessoas podem participar em troca de uma recompensa, eu bolei algumas delas pra quem participar. No site do embolacha está tudo explicadinho, esse trabalho pra mim é muito importante! Vamos juntos nessa, me ajudem a divulgar e contribuam!!” 
instrumentista não se confundia com o artista. $O$ intérprete não era necessariamente o compositor. O diretor artístico não fazia o trabalho do arranjador. A produção de um disco envolveria, segundo Morelli ([1991] 2009), duas grandes áreas: a material e a artísticomusical que expressavam a divisão entre fábrica e estúdio. Dias (2008) alerta para o fato de que os processos criativos dentro dos estúdios também são produção material, tanto quanto artística, criticando a divisão proposta por Morelli. Provavelmente, muitas das grandes Cias fonográficas que resistiram às crises financeiras desse início de século XXI ainda preservam essa estrutura interna com profissionais altamente especializados. Nas práticas dos compositores analisados aqui as coisas estão acontecendo de outra forma, especialmente no que diz respeito aos processos criativos dentro dos estúdios de gravação.

"A transformação começou no início dos anos 2000. As facilidades de gravar um disco "em casa" aumentavam na mesma velocidade em que o poder de fogo da indústria fonográfica caía. Na impossibilidade de construir uma carreira livre e autoral dentro do esquema das gravadoras, artistas saíram em busca de inventar os próprios métodos." (Trecho da reportagem "Neo mpb - Do camelô no Centrão à livraria da elite, como funciona a geração que faz hoje a nova música popular brasileira" assinada por Marcus Preto, publicada na revista Serafina, Folha de São Paulo, dia 29/04/2012).

Rodrigo Campos é ótimo instrumentista, ele toca extremamente bem percussão, cavaquinho e violão. Ele também compõem todas as músicas que grava. Ele interpreta. Ele procura recursos financeiros para realizar os ensaios e gravações do disco. Kiko Dinucci e Tatá Aeroplano também fazem de tudo um pouco, quando se trata da produção fonográfica de suas composições. Kiko ainda é capaz de fazer as capas do próprio disco. Em 2011, por exemplo, como já mencionamos anteriormente, ele criou a capa do disco Passo Torto, do grupo do qual faz parte ao lado de Rodrigo Campos, Rômulo Fróes e Marcelo Cabral. Em 2012 e 2013 Kiko seguiu criando capas para alguns dos discos que lançava, criando flyers para os shows desses discos e criando estampas para camisetas que passou a vender nos shows de seu outro grupo, o Metá-Metá. Como podemos descrever o que eles fazem de forma mais acurada? O que eles são realmente: músicos, intérpretes, compositores, instrumentistas, produtores musicais, artistas plásticos? Seria essa multiplicidade apenas uma característica do caráter independente desse meio musical? 


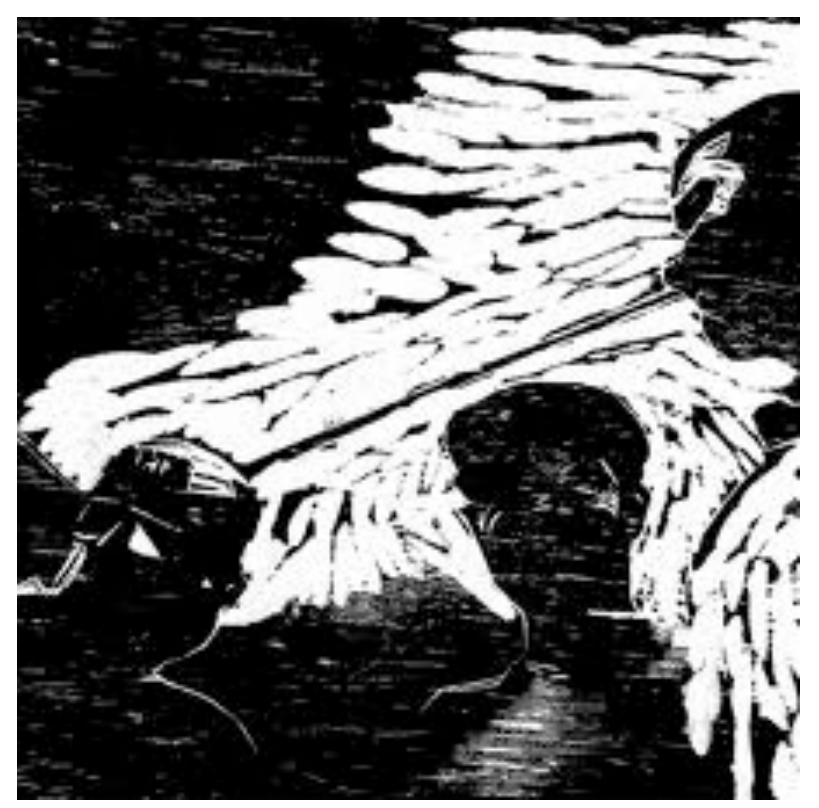

Capa do disco Passo Torto, gravura de Kiko Dinucci.

O fazer musical desse grupo sonoro é caracterizado por essa atuação multifacetada. Eles compartilham o fato de serem, ao mesmo tempo, produtores executivos de seus discos, compositores, intérpretes e instrumentistas. Eles se definem como músicos, mas são uma categoria específica de músicos. São músicos que criam composições inéditas e produzem autonomamente seus discos, artefatos físicos que tornam pública essa agência criativa. Veremos ao longo dos três capítulos dessa dissertação que os discos ao tornarem pública a obra dessas pessoas as transformam em artistas aos olhos do público. Como Antônio Cândido ([1965] 2006) nos ensinou, a tríade autor-obra-público é fundamental para compreendermos como as manifestações artísticas - sejam elas da literatura, da música ou das artes plásticas ganham contornos de realidade trocando propriedades entre si.

Tulipa Ruiz, Karina Buhr, Cidadão Instigado, Marcelo Jeneci, Bárbara Eugênia, Trupe Chá de Boldo, Andréia Dias, Iara Rennó, Lurdes da Luz, O Terno, Filarmônica de Pasárgada são alguns dos nomes que lançaram discos com repertório de canções autorais inéditas nos últimos três anos. Isso para citarmos somente nomes que residem em São Paulo e que trabalham com canção. Se estendermos pro universo da música instrumental, o número de discos lançados no mesmo período se multiplica. Discos instrumentais como os do Bixiga 70, Guizado e Marginalz, estão alcançando um bom reconhecimento de público e de mídia. Se considerarmos o Brasil, a vivacidade da produção fonográfica se mostrará incontestável, 
trazendo à tona uma infinidade de novos "artistas híbridos." Buscamos com esta dissertação apresentar as relações mutuamente generativas entre artistas, discos e público (sendo este último representado aqui fundamentalmente através das matérias de jornal e dos canais comunicacionais da internet), detalhando como esses três termos são sujeitos actantes que trocam propriedades entre si, um causando o outro, um trazendo o outro à tona. Não são apenas os artistas que gravam os discos; os discos também gravam os artistas.

Para dar corpo a essas questões dividimos o texto em três capítulos principais e uma última parte reservada às considerações finais. Os três capítulos buscam descrever os momentos e agências desse processo criativo musical de produção fonográfica, e apresentam três noções diferentes do que é um artista nesse universo musical. No primeiro momento, observamos os processos dentro de estúdios de ensaio e gravação acompanhando como os discos começam a ganhar contornos de realidade. O primeiro capítulo, "Da canção bruta à canção produzida", foi dividido em duas partes - na primeira parte trazemos a etnografia realizada num circuito de estúdios onde esses artistas circulam, e na segunda parte analisamos as transformações que uma canção - "Perigas Correr" - de Tatá Aeroplano sofreu no processo de produção para a gravação do disco. Todo o capítulo é fortemente inspirado nas etnografias musicais que detalham aspectos dos fazeres musicais e na perspectiva de Latour de seguir os cientistas dentro dos laboratórios. Veremos que os estúdios são recintos com vários traços comuns aos laboratórios, e os músicos - atuando junto aos computadores e demais equipamentos de áudio - apresentam traços paralelos aos dos cientistas tentando controlar e isolar pequenos trechos de realidade. Nesses recintos musicais, identificamos dinâmicas coletivas de arranjo, onde as fronteiras entre instrumentistas, compositores, técnicos de som se interpenetram. Todos trocam propriedades uns com os outros, não só humanos, mas também não-humanos (computadores, instrumentos, microfones, amplificadores). O domínio e o desenvolvimento dos equipamentos de gravação nos leva a reconhecer um curto-circuito entre arte e técnica no fazer musical desse grupo. A noção de artista que emerge nesse capítulo, é a noção dos próprios músicos: o artista é aquele que pensa o mundo através da música.

No segundo capítulo, "Os discos em ação", realizamos uma discussão das agências dos discos depois que eles estão prontos e já saíram dos limites dos recintos onde foram produzidos (os estúdios) a partir da teoria de Alfred Gell. Trata-se de uma experimentação com os conceitos de artista, indexe, recipiente e protótipo utilizados por Gell em Art and Agency (1998) na sua abordagem antropológica da arte. No nosso caso, os discos são os indexes que ora se 
comportam como agentes, ora como pacientes nas cadeias relacionais nas quais estão imersos. Refletir sobre a ação dos discos permite uma reconfiguração de seu lugar no universo musical contemporâneo fornecendo uma alternativa para as perspectivas que denunciam seu fim perante a predominância da música digitalizada. Logicamente, Latour também é um referência importante devido aos vários pontos em comum que sua antropologia simétrica apresenta com a perspectiva de Gell. Ao nosso ver, o que Gell chama de "coisa" ou "objeto" agente, Latour (2000, 2001, 2009) chama de "híbrido", misto de sujeito/objeto, natureza/cultura, discurso/realidade, humano/não-humano, entes que agem nas redes sóciotécnicas em que estão inseridos. Nesse capítulo, trabalhamos com a noção de artista formulada por Gell como o responsável causal da materialidade da obra de arte, ou seja, o artista é a força braçal que gera o um objeto como o disco (a mesmo tempo em que é gerado pelo disco).

No terceiro e último capítulo, "Cibercultura e música: sobre discos virtuais e usos da internet", veremos como esse disco reconfigurado que já saiu dos estúdios, já agiu na vida dos músicos, se comporta no ciberespaço, ou seja, como os discos agem na internet divulgando o nome dos nossos três interlocutores. O filósofo Pierre Lévy (1997) nos fornece os principais conceitos nessa etapa da dissertação - cibercultura, ciberespaço, digital e virtual. Acompanharemos os usos que os artistas fazem de sites e das redes sociais caracterizando um curto-circuito comunicacional com seu público. A internet se apresenta como uma revolução nas práticas comunicacionais que afeta diretamente o tripé autor-obra-público. Os discos digitais "vazam" pelas redes sociais atingindo rapidamente os ouvintes fãs de cada artista. As redes sociais da internet como facebook permitem uma interação direta entre público e autor, ambos estabelecem muitas vezes relações dialógicas online em que um influencia o outro, como veremos num curioso exemplo envolvendo Tom Zé, Kiko Dinucci e Tatá Aeroplano. Duas ideias do sociólogo Manuel Castells (2005) se adequam a aspectos importantes do fazer musical na era da sociedade conectada pelos computadores - a "comunicação de massa autodirigida" e o "trabalho auto-programável". Esses prefixos "auto" enfatizam a autonomia que diversas áreas profissionais estão alcançando com as novas tecnologias comunicacionais; os músicos não ficam de fora dessa autonomização do trabalho. O artista que emerge nesse terceiro capítulo é o artista com autonomia criativa que consegue divulgar sua obra no ciberespaço.

O leitor deve ter sempre em mente ao longo da dissertação esses três momentos descritos nos 
três capítulos: os discos e artistas em construção dentro dos estúdios, os discos acusticamente já prontos agindo e sofrendo agência na vida das pessoas que entram em contato com ele, e por fim, os discos disponibilizados gratuitamente no ciberespaço agindo através das redes sociais da internet. $\mathrm{O}$ curto circuito entre arte e técnica, a capacidade de ação do objetos e o curto circuito entre artistas e público são os elementos fundamentais que nos permitirão elaborar um resposta à nossa pergunta inicial: por que eles ainda gravam? 


\section{CAPÍTULO 1}

\section{Da canção bruta à canção produzida}

\section{Músicos e estúdios}

A antropologia da música procura descrever o universo sonoro humano falando de sons, de instrumentos, de melodias e harmonias (o que seria usual num estudo musicológico); mas também falando de parentesco, rituais, cosmologia, política, mitologia entre outras coisas (a parte propriamente antropológica da área). Uma boa pesquisa etnomusicológica conecta em sua narrativa dos fazeres musicais de um grupo elementos aparentemente não musicais. Para citar novamente duas grandes etnografias musicais lembremos que Anthony Seeger (2004), em Why Suyá Sing, analisa a Mouse Ceremony, as relações entre irmãos, a organização etária, entre outras coisas, para abordar a música desse grupo. Steven Feld (1982), em Sound and Sentiment: Birds, Weeping, Poetics, and Song in Kaluli Expression, fala de etnobotânica e da complexa classificação dos pássaros na sociedade Kaluli para analisar seus cantos. Tem que recorrer a um mito em que o irmão mais novo é abandonado pela irmã mais velha que se transforma em pássaro, para dar conta da complexidade musical de um determinado tipo de canto. Enfim, falar de música em antropologia implica numa narrativa que conecta outras áreas da vida social.

\footnotetext{
“A etnografia da música é o escrito sobre as maneiras que as pessoas fazem música. Ela deve estar ligada à transcrição analítica dos eventos, mais do que simplesmente à transcrição dos sons. Geralmente inclui tanto descrições detalhadas quanto declarações gerais sobre a música baseada em uma experiência pessoal ou um trabalho de campo." (SEEGER, 2008: 239).
}

Essa transcrição analítica dos eventos deve ser a mais detalhada possível. Detalhada num grau em que até um leigo em música seja capaz de compreender os aspectos extra-sonoros do fenômeno. John Blacking em Música, Cultura e Experiência (2007), afirma que as opiniões dos leigos na maioria das vezes são mais interessantes para uma compreensão mais abrangente da música do que as opiniões dos próprios músicos.

"Uma vez que tanto os ouvintes como os compositores e performers são parte do processo do fazer musical e desde que haja evidência de que todo ser humano tem 
capacidade de produzir sentido da música (cf. Blacking, 1973), a visão que um músico tem da música é uma fonte limitada de informação, até mesmo sobre os aspectos estritamente musicais de um sistema musical.” (BLACKING, 2007: 205).

$\mathrm{O}$ autor segue afirmando que a vida do músico exige muitas vezes tanta dedicação que o coloca numa situação de isolamento social. Suas (dos músicos) opiniões e visões não deveriam ser tomadas como fonte primária de informação. "E até que a importância das visões "leigas" na compreensão e na análise das músicas seja reconhecida, não progrediremos em direção à compreensão da "música" como uma capacidade humana." (BLACKING, Ibidem: 205).

Mais do que reconhecer as visões leigas, buscamos reconhecer também as agências nãohumanas do fazer musical. Reconhecer que a antropologia talvez seja o espaço privilegiado para conectar numa mesma narrativa seres humanos, instrumentos, estúdios, microfones, valores, relações familiares, discos, computadores, leis de incentivo à cultura, crise na indústria fonográfica, notícias de jornal etc. Estamos nos inspirando aqui em Jamais Fomos Modernos de Bruno Latour (2009), para quem a antropologia seria a forma de se conectar numa mesma descrição as natureza-culturas. Numa mesma análise fatos reais, sociais e discursivos aparecem juntos para explicar um povo, sejam os chineses ou os xavantes. Como afirma Latour:

"[...] o buraco de ozônio é por demais social e por demais narrado para ser realmente natural; as estratégias das firmas e dos chefes de Estado, demasiado cheias de reações químicas para serem reduzidas ao poder e ao interesse; o discurso da ecosfera, por demais real e social para ser reduzido a efeitos de sentido. Será nossa culpa se as redes são ao mesmo tempo reais como a natureza, narradas como o discurso, coletivas como a sociedade?" (LATOUR, 2009: 12).

A antropologia já faz esse tipo de descrição tradicionalmente quando aborda as sociedades não-ocidentais. Uma boa etnografia de um grupo indígena buscar conectar vida econômica, parentesco, arte, religião. Latour propõe uma simetrização radical da reflexão antropológica ao se debruçar sobre o mundo ocidental da mesma forma, criticando a separação que os modernos fazem entre natureza e cultura.

Este capítulo busca analisar fazeres musicais urbanos contemporâneos conectando numa mesma narrativa as agências humanas e não-humanas dos processos observados. É resultado de uma etnografia da gravação de discos na cidade de São Paulo que se estendeu de 2011 até 
início de 2013. Os músicos desse estudo são três compositores principais - Tatá Aeroplano, Kiko Dinucci e Rodrigo Campos - e suas respectivas bandas. Lembrando que nossa visão é de que esses três compositores são representantes de um grupo sonoro mais amplo formado por um grande número de pessoas que compartilham o fato de lançarem discos nos mais variados suportes e formatos, sem estarem necessariamente vinculadas a uma grande gravadora. Escrevemos sobre as maneiras através das quais um determinado grupo sonoro vem fazendo música na cidade de São Paulo, sendo que a gravação de discos se apresenta como o principal ponto comum que liga os membros desse grupo. A importância do disco como ferramenta criativa une artistas e bandas dos mais variados estilos e gêneros musicais. Os estúdios de gravação, os ensaios, a cidade de São Paulo, as fontes de financiamento de discos, os shows de lançamento são alguns dos elementos que irão contextualizar o fazer musical desse grupo ao longo do texto.

Os estúdios são elementos fundamentais no fazer musical urbano contemporâneo. Para Latour (2000) é na observação das práticas sociais dentro de laboratórios que está a possibilidade real de realizar uma etnografia da ciência, revelando a ciência em construção e não a ciência pronta e acabada, lacrada em caixas de pandora inacessíveis aos leigos. Nos deixando influenciar por essa antropologia da ciência, ouso afirmar que é dentro dos estúdios que podemos observar os discos em construção, não como dispositivos fechados e prontos, mas como processos, como interações associativas entre humanos e não-humanos, músicos e computadores, técnicos de mixagem e microfones, artistas e discos. O espaço físico do estúdio, onde pessoas se reúnem para gravar discos, foi o palco dos momentos mais significativos desta pesquisa de campo. O estúdio é um recinto dentro do qual os sons são manipulados. Ele cria um "dentro" e um "fora” a partir da manipulação sonora. O isolamento acústico é uma das principais características físicas dos estúdios, além de toda uma rede de complexos equipamentos de áudio. O trabalho de Stélio Marras (2009) é instigante para uma reflexão sobre recintos.

"Nos laboratórios, os recintos parecem simular o mundo sob controle. Como ambientes de alta domesticação científica, eles fazem passar do indeterminado para o determinado, do indiferenciado ao diferenciado. Podem reter o tempo ou acelerá-lo. No espaço dos envoltórios, containers, caixas, tubos, garrafas e mesmo salas ou equipamentos de acesso restrito, os recintos formam um ambiente que, como tal, cerca fronteiras entre o interior e o exterior, age diretamente no controle de variáveis, controle de permanências, engendram proibições e permissões, entradas e saídas de uma multiplicidade de agentes. 
A própria agência humana parece a de um maestro de uma orquestra rebelde, teimosa, vulnerável, custosa para domesticar." (MARRAS, Tese de Doutorado, 2009: 31).

Os estúdios são recintos onde humanos com a ajuda de diversos agentes não-humanos tentam manipular e controlar o universo dos sons. Tive oportunidade de passar por alguns dos principais estúdios de gravação da Zona Oeste de São Paulo: o Minduca no Jardim Bonfiglioli, o YB na Vila Madalena e o El Rocha em Pinheiros. Dentro desses três estúdios foram gravados alguns dos principais discos lançados em São Paulo entre 2011-2012. Alguns discos relevantes produzidos nesses estúdios durante o período da pesquisa, além dos discos de Tatá Aeroplano, Kiko Dinucci e Rodrigo Campos que serão analisados aqui, foram: Nó Na Orelha de Criolo gravado no El Rocha, Efêmera de Tulipa Ruiz gravado no YB, e Longe de Onde de Karina Buhr gravado no Minduca ${ }^{12}$. Esses três estúdios, ao lado do estúdio Traquitana (no bairro do Bixiga), formam um circuito ${ }^{13}$ de estúdios de gravação ocupados por uma série de artistas e bandas atuais que focam suas carreiras no lançamento de álbuns autorais. O objetivo principal não era mapear esse circuito, mas ele se delineou de forma indireta, na medida em que seguíamos os discos, os artistas e os shows.

Este capítulo está dividido em duas partes principais. Na primeira parte, apresentamos a etnografia de processos de produção de discos dentro desses três estúdios, descrevendo e discutindo as práticas observadas. Na segunda parte, me concentro na análise de uma única canção focando nas transformações que ela sofreu durante o processo de produção. A segunda está contida na primeira, é um recorte específico de um momento da etnografia dos discos descrita em detalhes na primeira parte. Nas considerações finais, procurei delimitar os aspectos mais significativos que caracterizam o fazer musical desse grupo sonoro fornecendo indícios fortes para uma reconfiguração do disco como objeto artístico no cenário musical contemporâneo.

\footnotetext{
${ }^{12}$ Para se ter uma ideia imediata da relevância destes discos, basta conferir as listas de melhores discos nacionais de 2011 e 2012 publicadas por várias mídias como a revista especializada em música Rolling Stone. Todos esses discos figuram nas listas dessa revista e de importantes mídias brasileiras.

${ }^{13}$ Utilizo aqui a noção de circuito formulada por José Guilherme C. Magnani. Uma noção que une "estabelecimentos, espaços e equipamentos caracterizados pelo exercício de determinada prática ou oferta de serviço, porém não contíguos na paisagem urbana..." (MAGNANI, 2008: 45). Neste caso, espaços equipados que oferecem a infraestrutura para produção de discos.
} 


\section{$1^{\text {a }}$ Parte - Seguindo discos e artistas em construção - etnografia dentro dos estúdios}

\subsection{Minduca - Tatá Aeroplano}

"Dustan - Bora menorizar esse Dó!

Boca - Ah, menorizar que tu diz é torná-lo menor!

Dustan - Imagina uma coisa assim: tã, tã, tá, tá, tá, tã... (cantarolando uma melodia para Bruno e Boca). Aí, depois a gente arma isso bem feitinho, as notas.

(Os três tocam um pouco juntos)

Dustan: (Para o Bruno) Talvez seja só na cabeça mesmo. (Para o Boca) Vamos picadinho juntos, qualquer nota por enquanto.

Boca: Vamos fazer o arpejo. (Ele e Dustan tocam juntos as notas nos seus instrumentos). Seguir a linha de baixo que tu diz?! Faz tu e Bruno pra eu ouvir.

(Boca para, escuta um pouco e continua a tocar junto) Meio roquinho... Essa intro vou fazer a guitarra mais doidinha (toca frases na guitarra) Toca aí tu e Bruno que aí eu... (Dustan começa a tocar com Bruno sendo seguido em questão de segundos pela guitarra de Boca)." (Diálogo no estúdio Minduca, dia 5/12/2011, durante as gravações do disco solo de Tatá Aeroplano).

O trecho reproduzido acima é a transcrição de um diálogo que aconteceu no primeiro dia das gravações do disco, Tatá Aeroplano, 5 de dezembro de 2011, no estúdio Minduca. Estávamos juntos dentro da sala de gravação: Tatá Aeroplano, Dustan Gallas, Bruno Buarque, Junior Boca e eu. Dustan Gallas tocava seu baixo Hofner de 1972, enquanto Junior Boca tocava sua guitarra Gretsh Corvette de 1967 e Bruno Buarque sua bateria Slingerland Radio King de 1956. Os instrumentos tem nome, tem data de nascimento, eles desenham linhas e tocam frases. Seriam eles também humanos como os músicos? Interessante notar como os músicos humanizam seus instrumentos, por exemplo, "guitarra mais doidinha".

Tatá ouvia atento as ideias dos músicos sobre a introdução da canção "Perigas Correr" que estavam começando a arranjar. Minutos antes, todos ouviram a gravação guia que Tatá havia feito com voz e violão, uma gravação caseira para auxiliar na gravação oficial. Uma gravação guia serve de ponto de partida para uma banda ou um grupo de músicos que começam a produzir uma canção. Normalmente, é uma gravação somente com voz e algum instrumento de acompanhamento harmônico. Nesse caso, temos o violão de Tatá como acompanhamento. 
Muitas guias feitas para este disco foram gravadas por mim na sala do apartamento em que Tatá mora há mais de quinze anos no bairro de Santa Cecília. Ele interpretou todas as canções ao vivo com seu violão e eu captei a performance com um microfone, uma placa de som e meu laptop. As estruturas das composições nessas versões mais cruas normalmente são bem simples. Estão apoiadas na letra da música sem partes instrumentais, sem preocupação com introduções ou finais. Os outros músicos ouviram a gravação de voz e violão juntos. Dustan, que também é produtor musical do disco, começou a tocar algumas notas no baixo logo depois que ouviu a canção. Bruno começou a marcar o ritmo na bateria e todos começaram a conversar e tocar sobre o que se transformaria na introdução instrumental da música.

Logo no início do diálogo, Dustan pede para Boca menorizar um acorde. Boca interpreta rapidamente o que seu colega quis dizer. Menorizar nesse caso significa transformar um acorde maior em menor ${ }^{14}$ modificando sutilmente a harmonia da introdução. Em seguida, Dustan pede para Bruno tocar só na cabeça. Ele quer dizer para o baterista entrar na cabeça do tempo (o tempo tem uma cabeça?), ou seja, marcar sua entrada no primeiro tempo do compasso. Para o guitarrista, ele diz "vamos tocar picadinho", tocar as notas bem separadas uma da outra, sem ligação, picadas nesse sentido. Boca diz que vai tocar meio roquinho uma guitarra mais doidinha. O que pude perceber que ele fez naquela hora foi tocar suas frases com um efeito de pedal (distorção ${ }^{15}$, no caso) e utilizando alguns bends ${ }^{16}$. Todo diálogo é intercalado por sons, frases de guitarra e baixo e bateria, os músicos verbalizam suas ideias, mas precisam completá-las utilizando seus instrumentos. $\mathrm{O}$ discurso verbal se mistura e se intercala com o discurso musical dos instrumentos. É como se as ideias de cada um não se completassem apenas com palavras. Ao final deste trecho, Boca diz "Toca aí tu e Bruno que aí eu..." e começa a tocar sua guitarra junto com os outros. Sua fala termina no ar e é completada segundos depois pelas frases de guitarra. Assim como os discursos verbais e nãoverbais se misturam, características humanas se misturam à coisas aparentemente não-

\footnotetext{
${ }^{14}$ Os acordes musicais básicos são formados pelas tríades: Tônica, Terça e Quinta. Por exemplo, um acorde de Dó é formado pelas notas dó (tônica), mi (terça) e sol (quinta). A diferença entre maiores e menores é determinada pela distância da terça em relação `a tônica. As terças maiores que formam os acordes maiores são mais distantes do que as terças menores.

${ }^{15}$ A Distorção é um efeito bastante utilizado, especialmente entre guitarristas. A distorção simula uma saturação do som de um instrumento elétrico.

${ }^{16}$ Um bend é uma técnica utilizada para mudar uma nota tocada em instrumentos cordofônicos como guitarra ou baixo. Nesse tipo de técnica, o músico muda a nota levantando a corda para cima ou puxando para baixo.
} 
humanas. Frases, cabeça, doidinha, picadinho são termos utilizados pelos músicos para organizar a música que estão começando a produzir que remetem a domínios extramusicais.

Esse tipo de diálogo revela uma linguagem musical comum compartilhada por todos, característica que demarca um grupo sonoro. A linguagem musical está dividida em dois tipos de discursos "contrastantes mas complementares, que são componentes necessários do fazer musical e que também podem revelar como as pessoas pensam sobre música" (BLACKING, 2007: 207) - o verbal e o não-verbal. Analisar o modo como as pessoas pensam e fazem música passa pela análise dos dois tipos de discurso. Nos diálogos dentro de estúdio, no calor da criação, muitas vezes os músicos interrompem uma fala para tocar notas no instrumento, como no caso descrito acima. Apesar de separarmos esses dois discursos ao descrever esses processos, na prática eles caminham juntos. Cirino (2009), na sua etnografia da Música Popular Instrumental Brasileira (MPIB), observa que existe uma tradição oral-aural e uma tradição escrita na música. A MPIB incorpora aspectos das duas tradições - ora mais popular, ora mais erudita - na visão de Cirino. No caso dessa gravação de disco, pode-se afirmar que predomina uma tradição oral-aural onde os discursos verbais e não-verbais se complementam no processo criativo. Essa tradição oral-aural é a tradição musical onde não existe partitura escrita, onde o aprendizado acontece com base na capacidade de ouvir, memorizar e imitar. Toda tradição da música clássica europeia é baseada na partitura escrita. Eu mesmo tive oportunidade de estudar piano quando criança, e desde as primeiras aulas o professor me ensinava como ler e escrever partitura. Aqui, não encontramos em nenhum momento a preocupação em escrever notas numa partitura.

Para chegar ao estúdio neste primeiro dia, ofereci uma carona para Tatá Aeroplano. Nos encontramos às 13:30 no bairro de Santa Cecília e seguimos sentido Butantã. Passei no LISA (Laboratório de Imagem e Som em Antropologia) na USP para pegar a câmera de filmagem. O LISA é a cede do Grupo de Antropologia Visual da USP - GRAVI - do qual faço parte desde 2011. Financiado pela FAPESP, o GRAVI está envolvido com um amplo projeto temático que abarca diversos pesquisadores que de alguma forma lidam com antropologia e imagem. Nesta etnografia, a filmadora em punho se mostrou um bom aliado num lugar estranho onde eu me sentia um intruso. Me refiro aqui, não ao lugar físico - o estúdio - mas ao lugar social de pesquisador onde eu me encontrava. Eu sou músico há quase vinte anos, os estúdios me são familiares, entretanto, entrar num estúdio como antropólogo me era totalmente novo. No meio daquela gravação de disco - em que eu não era músico, não era 
produtor, nem compositor - eu tinha um função prática; filmar ${ }^{17}$. A filmagem é um recurso poderoso para uma pesquisa antropológica. David MacDougall, importante teórico e pesquisador da antropologia visual, disse em entrevista cedida à Lilian Sagio Cezar: "Para mim, fazer filmes é parte da minha vida, é uma forma de me relacionar com o mundo, com outras pessoas. Sem a câmera eu nunca teria aprendido as coisas que aprendi." (in Cadernos de Campo, n 16, 2007: 181).

Rose Satiko Gitirana Hikiji (2006) utilizou oficinas de vídeo e a prática da filmagem como forma se comunicar com os atores de sua pesquisa, menores internos da Febem que estudavam música pelo Projeto Guri. “O vídeo foi também, inúmeras vezes, instrumento mediador de minha comunicação com os jovens, nem sempre fácil dada a situação de internação e as diferenças que nos separavam.” (HIKIJI, Ibidem:39).

Fazer uma filmagem foi a forma que encontrei de me relacionar com músicos dentro de um estúdio para registrar processos íntimos de criação artística. Prometi ao Tatá Aeroplano que daria cópias de todas as imagens captadas para ele guardar como registro e utilizar como quisesse; era uma espécie de contrapartida por ele me deixar participar de um momento tão íntimo e importante de sua vida. MacDougall também nos lembra que é “importante para o cineasta reconhecer quais são os interesses presentes, uma vez que as pessoas podem usar seu filme para demandas específicas." (CEZAR, 2007: 184). Na minha experiência etnográfica, algumas dessas demandas surgiram depois das minhas filmagens. Rômulo Fróes, compositor parceiro de Kiko Dinucci e Rodrigo Campos no grupo Passo Torto, me pediu as filmagens que realizei de seus ensaios, depois que o cineasta responsável pela produção de um filme do grupo ficou sabendo da minha pesquisa.

Por volta das 15 horas, chegamos na casa de Bruno Buarque, dono do estúdio Minduca. Na verdade, o estúdio Minduca fica no porão de sua casa. Se resume a uma grande sala repleta de instrumentos e equipamentos de gravação com as paredes forradas com pôsteres, adesivos e instrumentos pendurados. Nesta sala, existe um banheiro que também é utilizado como

\footnotetext{
${ }^{17}$ Rose Satiko Gitirana Hikiji (Ibidem) comenta um pouco do estranhamento que sentia enquanto pesquisadora na Febem e de como oficinas de vídeo amenizaram esse estranhamento. "A oficina, para nós, era também uma tentativa de romper com as dificuldades impostas pelo estranhamento que caracterizava nossa relação com o grupo... Percebemos na oficina... uma forma de ganhar um lugar no cotidiano dos jovens." (Ibidem: 27). Na minha experiência, não realizei oficinas de vídeo, mas a filmadora e/ou a intenção de produzir um filme me ajudou a ter um lugar dentro dos grupos.
} 
ambiente de gravação. As vozes do disco foram gravadas neste banheiro. Apesar de ser localizado dentro da casa de Bruno, este estúdio já não é um simples home studio (estúdio caseiro); os equipamentos são de altíssima performance e qualidade ${ }^{18}$. Ele já possui uma qualidade técnica elevada, o que permite gravar discos com um som considerado muito bom para os padrões do mercado.

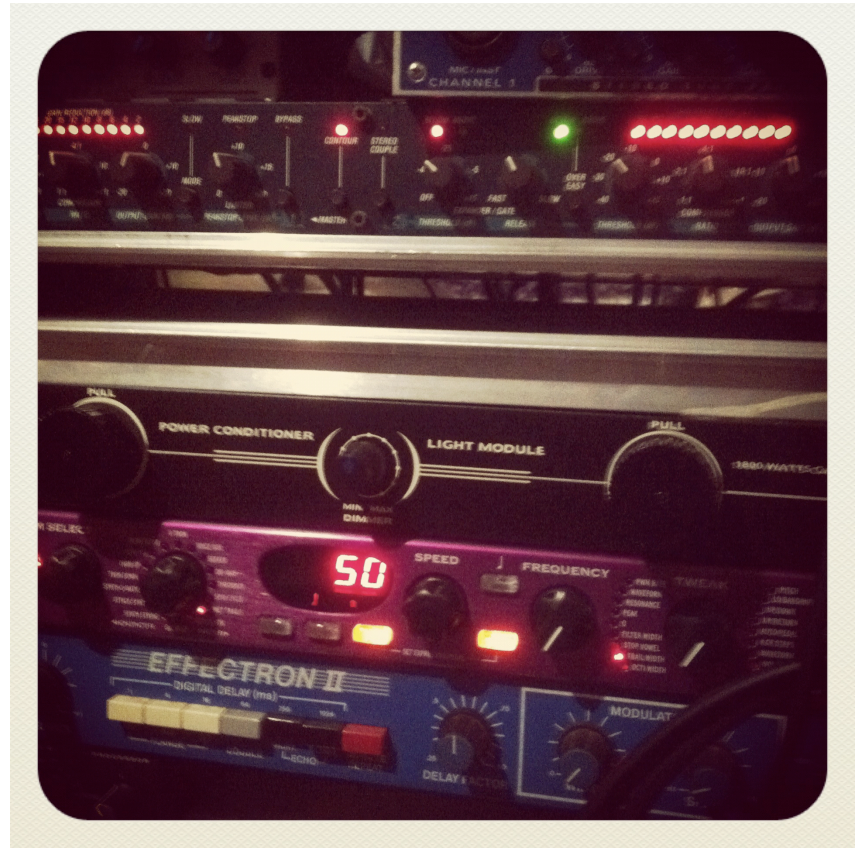

Parte da parede de pré-amplificadores do Minduca

Bruno Buarque é baterista das cantoras Céu, Karina Buhr e Anelis Assumpção. Gravou boa parte dos discos destas duas últimas cantoras dentro do Minduca. Ele ainda trabalhou anos com o Barbatuques, grupo famoso pelo desenvolvimento da percussão corporal. Eu já o conhecia como músico há mais de 14 anos, porém é a primeira vez que acompanho gravações no seu estúdio. Tatá Aeroplano não conhecia Bruno Buarque pessoalmente e a relação entre os dois começou a partir do disco. Tatá conheceu primeiramente Dustan Gallas e Junior Boca durante as gravações de outro disco, o primeiro álbum de Bárbara Eugênia, Journal de Bad. Tatá conta que gostou do jeito de Dustan trabalhar (Dustan também foi produtor de Journal de $\mathrm{Bad}$ ) e o convidou para produzir seu disco. "Nunca ninguém havia me respeitado tanto como músico quanto Dustan e Boca na gravação da Bárbara", conta Tatá. Dustan convidou Junior Boca e Bruno Buarque para gravarem juntos e recomendou o Minduca. Os encontros

\footnotetext{
${ }^{18}$ Os equipamentos mais caros dentro de um estúdio, normalmente, são os chamados préamplificadores, equalizadores, compressores e microfones. Os computadores já não são tão caros e específicos. Um home studio básico normalmente é formado por uma placa de som, um computador e alguns poucos microfones; não tem muitos pré-amplificadores e opções de microfonação.
} 
de todos esses músicos aconteceu por causa de discos, ou seja, discos agenciaram esses encontros.

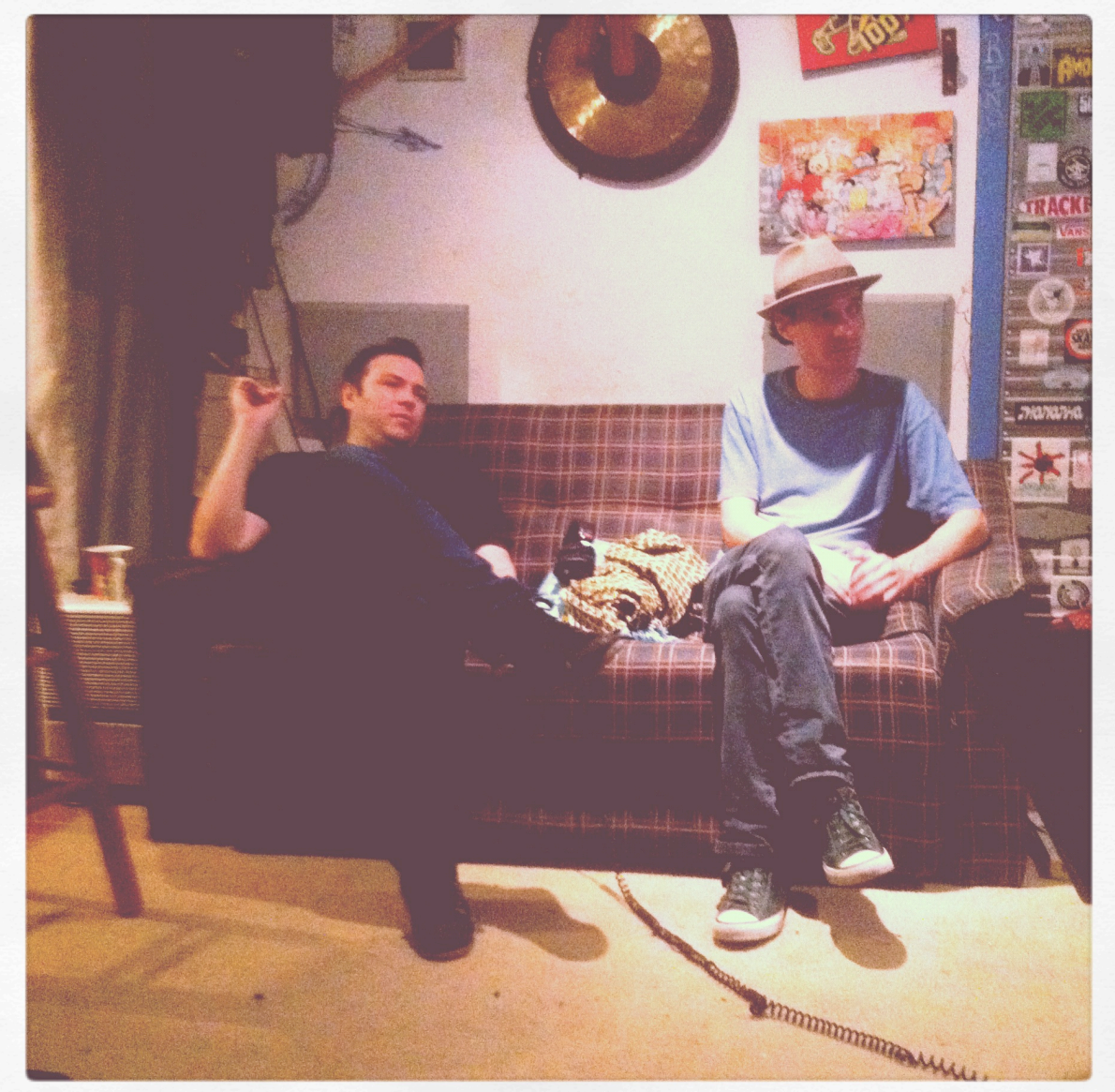

Dustan (à esquerda) e Tatá Aeroplano dentro da sala de gravação do Minduca

O Minduca, como o seu dono costuma dizer, é um estúdio com clima de casa e com qualidade técnica profissional. Casa versus profissional, lazer versus trabalho, arte versus mercado são dicotomias presentes no fazer musical urbano desse grupo. Os músicos ficam a vontade, sem a paranoia do tempo correndo que é uma característica dos grandes estúdios. Os contratos tradicionais com estúdios de gravação são feitos por hora; o contratante aluga a infraestrutura por hora ${ }^{19}$. No acordo entre Tatá e Bruno, eles fecharam um pacote por todo o processo. A expressão pacote é bastante comum nesse meio musical. Ensaiar, arranjar, gravar são atividades incluídas nesse pacote na maior parte das vezes. O que importa para todos é que ao final do pacote um belo disco tenha sido criado.

${ }^{19}$ O estúdio Nacena, famoso em São Paulo pela sua excelente infra-estrutura técnica, cobrava em média 140 reais por hora em 2012. Os valores variavam um pouco de acordo com o tipo de gravação, tamanho da sala, técnico de som contratado etc. 


\subsection{Intimidade com a tecnologia - $O$ produtor musical como mediador entre técnica e arte}

No segundo dia de gravação, 6 de Dezembro de 2011, Bruno Buarque resolveu chamar um assistente de gravação para apoiá-lo na operação dos equipamentos. Ele percebeu que seria muita coisa atuar como técnico de som, engenheiro de gravação, baterista e arranjador num único disco. Ele acabou fazendo de tudo um pouco durante o processo, mas agora tinha uma ajuda a mais no apoio técnico, o assistente de gravação Delão Calvente.

"Bruno conversando com o assistente Delão: Curso rápido para você começar a fazer essa operação aqui. A gente vai gravar guitarra, baixo e bateria junto, e voz. Já tá tudo recado, ó! Ela tá na ordem do input, 1, 2, 3, 4, 5, 6, 7 e 8. Aqui, ó! Tô trigando o bumbo e a caixa. Aqui os inputs. A guitarra tá no talo, ó! Se isso estourar é preocupante (aponta para algum marcador no equipamento). Se estourar a gente vai no pré correspondente e abaixa...

Aqui você dá um maçã tab e ele vai pro apogi. Aqui você controla o volume do seu fone se ele estourar, dá um clear meters. Aqui reseta, sacou?! Para gravar aperta R de recordare, parar a gravação barra de espaço e maçã S para salvar, quem ama salva!"

Esse curso rápido que Bruno Buarque ministrou em menos de 3 minutos no segundo dia de gravação revela a familiaridade que os músicos contemporâneos têm com a tecnologia. Esse diálogo seria difícil de imaginar numa gravação de disco nos anos 80; um baterista atuando ao mesmo tempo como técnico de som, ensinando um jovem assistente a operar o equipamento no meio de uma gravação de disco. No esquema das grandes gravadoras, onde cada um tem uma função bem definida, o dono do estúdio, o técnico de som, o baterista, o assistente e o produtor musical normalmente são pessoas diferentes. Dias (2008) apresenta uma rica descrição analítica do processo técnico e social da produção de discos dentro de grandes companhias fonográficas brasileiras, que se aprofunda na análise das relações sociais de produção vigentes entre os diferentes tipos de trabalhadores artísticos e as gravadoras. Existe (ou existia) uma divisão do trabalho mais rígida dentro das grandes companhias fonográficas. 


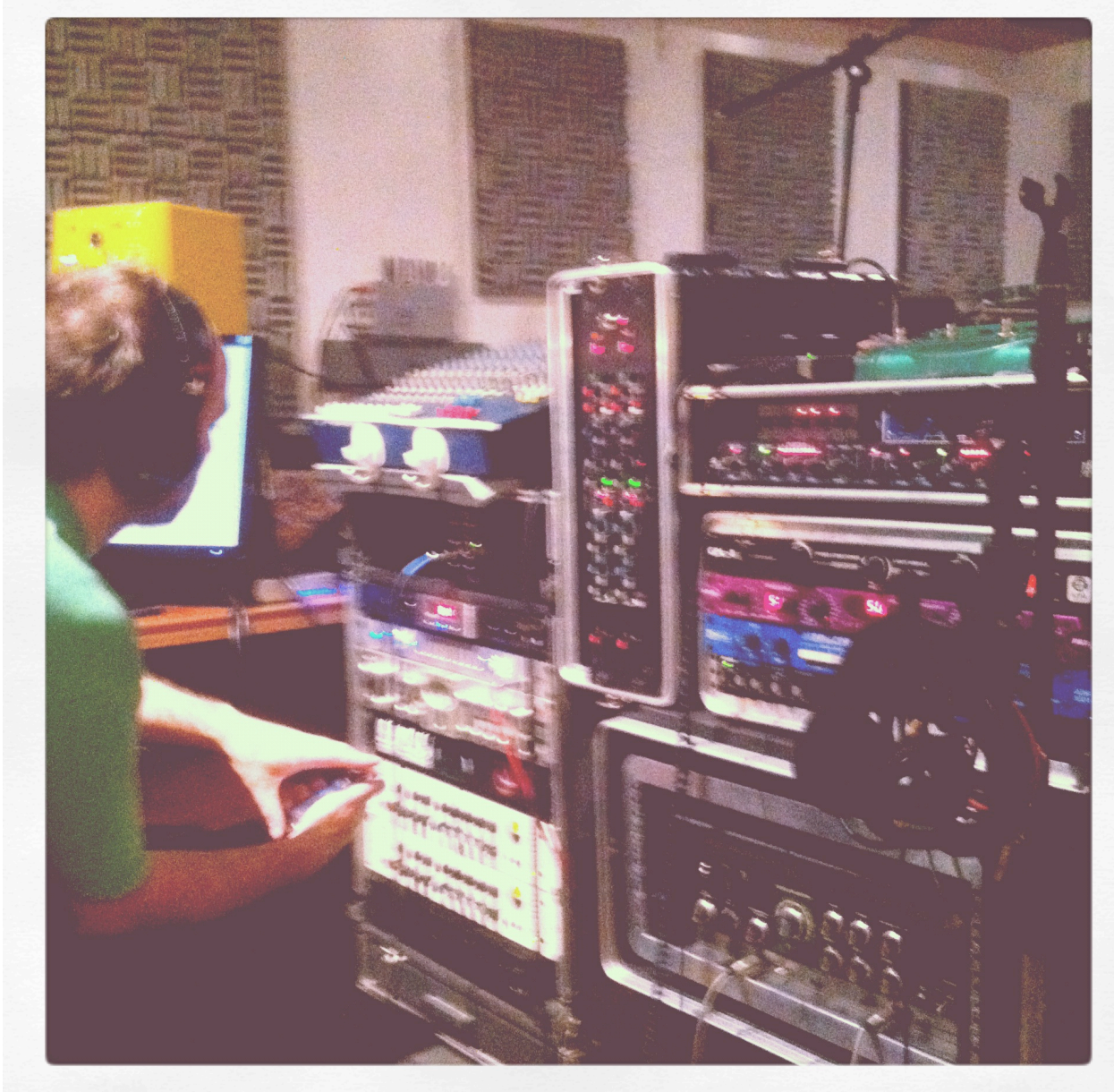

\section{Bruno Buarque e seus equipamentos}

No fazer musical desses músicos e artistas contemporâneos que observo, todo mundo acaba fazendo de tudo um pouco. Bruno Buarque não é simplesmente um baterista; é dono de um estúdio, é técnico de gravação, domina seu equipamento, dá ideias nos arranjos das canções, ajuda a equalizar e timbrar a guitarra e o baixo. Timbrar é o verbo utilizado para designar a atividade de trabalhar o timbre dos instrumentos e dos sons captados dentro do estúdio. É um termo bastante utilizado pelos artistas, porém é bastante controverso. Dustan definiu timbre da seguinte forma:

“Timbre é uma palavra bonita que só... é um conceito, mas é sobre sensação... ou seja subjetiva. São várias coisas ao mesmo tempo...a definição é simples, é tipo o resultado da variação da articulação aplicada numa nota musical qualquer (todas!)... difícil é fazer isso por mais de 5 segundos... ahhaaa.

É o rg (com foto!) de cada nota, o conceito é confundido (e generalizado mas acaba sendo mais útil assim), como um efeito numa guitarra por exemplo... nem é isso. Você 
timbra cada nota... é massa... timbre é dessas palavras tipo "estirpe"... quando usada metaforicamente... quase virando índole...

Pronto!! Timbre é a índole da nota musical..." (Entrevista com Dustan Gallas, dia 18/12/2011).

Em entrevista como o guitarrista Boca perguntei o que significa "timbrar um instrumento". Ele me explicou o seguinte:

"Cara, acho que você não timbra o instrumento, você timbra o som, né? O instrumento já vem com o timbre definido. Uma guitarra ou violão de determinada marca, tem seu timbre característico... você liga ele no amplificador e vai timbrar o som mexendo no equalizador ou no que mais for... mas o timbre do instrumento já é dele próprio, a guitarra e o baixo.

Cara, o timbre é um dos 4 parâmetros do som: altura, timbre, duração e intensidade. Altura, nesse caso, não é volume... é grave e agudo! O timbre é como o som da guitarra soa... como se fosse a cor, a cor do som. Você tem uma guitarra, ela já tem o timbre característico dela, mas você pode timbrar o som dela de várias maneiras diferentes, mais grave, mais agudo ou mais médio" (Entrevista com Junior Boca, dia 23/03/2012).

Dustan, Bruno e Boca se preocupam bastante com o timbre dos instrumentos. Fazer música passa pela responsabilidade com a "índole" e a "cor" das notas. É como se a nota tivesse um aspecto moral (índole) e um visual (cor) - de novo o discurso humaniza entes não-humanos e mistura termos de outras esferas da vida à esfera musical. Essa elaboração verbal de timbre caminha lado a lado com noções técnicas de áudio (altura, intensidade, duração). Eles tem que tocar bem seus instrumentos, fazer as notas soarem bem, saber gravar, equalizar e criar arranjos. Se por um lado ficam sobrecarregados de funções, por outro ganham uma autonomia criativa sem precedentes no mundo fonográfico. Ao mesmo tempo em que os músicos timbram o instrumento, os instrumentos possuem um timbre definido, ou seja, o instrumento também cria o timbre, o instrumento também age nesse sentido e muitas vezes determina o jeito que o músico toca ${ }^{20}$. Os instrumentos tocam os músicos, tanto quanto os músicos tocam os instrumentos.

\footnotetext{
${ }^{20}$ Quem toca um instrumento acústico sabe que mesmo dois instrumentos aparentemente iguais, feitos no mesmo ano pelo mesmo luthier, podem soar diferente. Especialmente instrumentos de madeira como violão, violino, piano, são vivos, possuem um som próprio e um som que pode variar ao longo
} 
A fala de Bruno para Delão fica difícil de acompanhar quando começa a utilizar os jargões técnicos de sua prática musical multifacetada dentro do estúdio. Quando diz "Já tá tudo recado”, por exemplo, está afirmando que os canais dos instrumentos estão ativados no software de gravação, isto é, estão prontos para gravar o áudio. Input é a entrada, é um lugar por onde o sinal de áudio dos instrumentos entra no equipamento. Trigando é um termo que vem de trigger, gatilho em inglês, para quando o sinal de áudio de uma parte da bateria está sendo duplicado por um sample. Sample também vem do inglês e pode ser traduzido como amostragem. Normalmente, uma amostragem de outra música que foi recortada e reutilizada. Nesse diálogo, Bruno afirma que bumbo e caixa, duas partes da bateria, estão trigadas, ou seja, quando tocadas acionam um gatilho que dispara um sample (provavelmente outro som de bumbo e caixa que Bruno recortou de outra música para dobrar ao som natural de seu instrumento). Os comandos do software de gravação acabam se transformando em novos verbos revelados nas falas dentro do estúdio. O discurso humano absorve elementos das máquinas. Essa intimidade com as máquinas só se tornou mais ampla com o desenvolvimento de interfaces entre humano e computador que fossem mais amigáveis para o leigo em programação. Joon Ho Kim (2005) analisa esse processo de desenvolvimento das chamadas interfaces gráficas que facilitaram muito a operação de softwares sem comandos textuais complexos.

Talo significa que o volume está no limite mais alto possível. Maçã Tab são as teclas do computador Apple que executam determinado comando no software. Enfim, existe uma língua paralela neste mundo tecnológico dos estúdios de gravação. Os músicos e artistas que gravam discos acabam aprendendo na prática os termos e jargões técnicos desse fazer musical. Esse fazer musical é caracterizado pelo domínio do instrumento musical propriamente dito (uma bateria no caso do Bruno Buarque) e pelo domínio dos processos técnicos de gravação (que envolvem os conhecimentos necessários para operação de softwares, dos equalizadores, pré-amplificadores, compressores e microfones). Esse domínio de múltiplas tarefas e conhecimentos caracteriza esse grupo sonoro do qual fazem parte diversos músicos de São Paulo. Devido à proliferação desse tipo de domínio técnico entre músicos, a gravação de discos se proliferou e ganhou força ao longo dessa primeira década do madeira eles são bastante vivos, e uma simples variação na temperatura e na umidade do ambiente transforma aspectos timbrísticos do som. 
século XXI. Muitas vezes a escolha de um estúdio é determinada pelos equipamentos que ele disponibiliza. Bons pré-amplificadores são aliados fortes nessas escolhas. "O pré serve pra esquentar o som" conta Bruno Buarque. As falas humanizam os equipamentos, misturam o corpo humano dos músicos aos hardwares e softwares, e maquinizam a criação humana.

Assim como Bruno Buarque, Dustan Gallas também não pode ser considerado somente um instrumentista, ou seja, um músico capaz de executar com exatidão e competência o baixo, a guitarra ou os teclados. Ele fez muitas outras coisas em seu home studio nesse disco de Tatá Aeroplano. Ele gravou camadas de teclados e mixou boa parte do material sonoro do disco num momento posterior aos dias que passaram no Minduca. Vale ressaltar que mixar um disco é uma das etapas mais complexas e importantes de todo processo. A mixagem também exige bastante conhecimento técnico e normalmente é uma tarefa para especialistas. Resumidamente, é o momento de regular os volumes e frequências de todos os instrumentos. O responsável pela mixagem, deve ouvir separadamente cada instrumento gravado, cada canal de áudio existente numa sessão, realizando essa regulagem de frequências e volumes para depois juntar tudo na massa sonora completa do disco. No caso deste disco do Tatá Aeroplano, Bruno Buarque e Dustan Gallas fizeram um trabalho tão bom na captação e na mixagem, que quando o material foi enviado a um especialista em mixagem ele disse que não precisaria mexer em nada. Dustan Gallas também está habituado a operar softwares de gravação, e parte de seu processo de produção musical está ligada ao tempo sozinho que passa em seu estúdio caseiro gravando com calma camadas de melodias e harmonias nas canções que ajuda a produzir.

A produção musical de uma canção está ligada à sobreposição de camadas melódicas, rítmicas e harmônicas. Ouvi Tatá Aeroplano dizer algumas vezes, que o bom produtor musical deve respeitar ao máximo a canção, em sua forma mais pura, para não "assassinar a canção". Uma definição mais formal do que é um produtor musical me foi fornecida por Guilherme Kastrup, baterista e produtor musical que já realizou trabalhos com Kiko Dinucci e Rodrigo Campos. Segundo Kastrup, o produtor musical "é aquele responsável por aliar a parte técnica com a parte artística, fica no meio do caminho entre o artista e os equipamentos do estúdio, tem que tentar traduzir o que o artista quer dizer através dos meios técnicos disponíveis." O produtor musical aparece aqui como um mediador de dois universos - o técnico e o artístico. Ora, acabamos de ver que uma característica que marca esse grupo é que todos possuem um bom conhecimento técnico aliado ao artístico. Isto significa que todos 
envolvidos são em alguma medida produtores musicais - o baterista Bruno, o guitarrista Boca, o baixista e tecladista Dustan e o cancionista Tatá ${ }^{21}$. Dias (2008), discute o produtor musical dentro da grande indústria fonográfica mostrando que ele deve conciliar interesses diversos na execução de um projeto, em especial, conectando uma preocupação comercial ao universo artístico. Essa é a grande diferença que o produtor musical de uma grande indústria apresenta em relação à ideia de produtor musical desse grupo, a necessidade de se responsabilizar pelo lado comercial do disco:

"Se o disco é um produto cuja característica primordial é a de encerrar a contradição entre produção material e produção artística, o produtor musical concentra, ele mesmo, contradição similar, que se expressa na esfera da execução do planejamento efetuado para o produto. Nesse sentido, a partir de um trabalho altamente técnico e especializado, o produtor musical concilia interesses diversos, tornando o produto musicalmente atrativo e economicamente eficiente; como parte do quadro funcional da companhia, realiza, no estúdio, a proposta de atuação desta." (DIAS, 2008:95).

Mas mesmo com essa importante diferença, o produtor musical de uma grande indústria é também um mediador; ele pode ser pensado como o responsável pela mediação entre arte e mercado $^{22}$. Todo artista desse grupo sonoro é em alguma medida um mediador de universos diversos. No discurso do produtor Guilherme Kastrup esses universos são identificados como a arte e a técnica. Aproveitando outras dicotomias que aparecem, por exemplo, nos trabalhos sobre xamanismo poderíamos pensar na arte como o domínio do invisível, do extracorpóreo, do imaterial. A técnica como o domínio do visível, do corpóreo e do material ${ }^{23}$. Tatá Aeroplano costuma dizer que algumas músicas ele "recebe prontas". Recebe de um plano

${ }^{21}$ Tatá inclusive já assinou a produção musical do disco da cantora e atriz Mayana Moura, assina também a produção do disco solo de Juliano Gauche previsto para o $2^{\circ}$ semestre de 2013 , e foi convidado por Gustavo Galo, compositor da Trupe Chá de Boldo, para produzir seu próximo disco.

${ }^{22} \mathrm{O}$ universo do mercado faz toda diferença. Pelo que emerge da análise de Dias (Ibidem), o produtor musical numa grande indústria tem, muitas vezes, a responsabilidade de fabricar ou encontrar grandes estrelas da música. Essa árdua tarefa não é uma preocupação do produtor musical nesse grupo sonoro.

${ }^{23}$ Pedro Peixoto Ferreira (2006), na tese "Música Eletrônica e Xamanismo Técnicas contemporâneas do êxtase" traz uma discussão sobre DJs como mediadores musicais. Ele trabalha com discursos de DJs que falam de xamanismo. Segundo um dos de seus interlocutores, o DJ Mantrix, "o dj nada mais é do que um ente que tem por função transmitir o que há no mundo extracorpóreo ao mundo corpóreo." (FERREIRA, 2006: 40). Essa transmissão de um mundo para outro é algo que o aproximaria do xamã, e trata-se de uma transmissão que também envolve técnicas. O DJ emerge como o xamã que domina técnicas musicais que conectam mundos distintos. O DJ cria o som e o som cria estados alterados de consciência onde o mundo corpóreo (externo, material) se conecta ao não-corpóreo (interno, espiritual). O autor se apoia bastante na obra de Viveiros de Castro para traçar sua análise do DJ como mediador de mundos distintos. 
invisível e extracorpóreo. Por outro lado, para realizar seu disco, o artista capta recursos financeiros e materiais, monta uma equipe (uma banda, um produtor musical), define qual melhor estúdio, quais equipamentos que precisa, define a imagem da capa e elabora uma estratégia de lançamento e de vendas. Ele cuida de todas essas etapas que seriam o lado mais técnico e/ou material de seu fazer musical. Importante lembrar aqui uma discussão de Latour sobre técnica onde o autor critica a técnica como um algo descolado da realidade, como uma entidade flutuando no vazio, como um "vil substantivo" (LATOUR, 2001: 219). Ele prefere pensar na técnica como um adjetivo que pode ser empregado em diversas situações. No nosso caso, o termo "técnica" emergiu do discurso nativo e pode ser pensado aqui como um adjetivo acoplado ao fazer musical desses músicos. O fazer musical é técnico e artístico ao mesmo tempo; existem aspectos mais e menos técnicos, mais e menos artísticos.

Kiko Dinucci é um dos artistas que lançou mais discos nestes últimos anos. Ele está muito bem resolvido tanto na parte artística quanto na parte técnica de seu processo criativo. Ele é um mediador competente de universos diversos e se conecta a outros mediadores competentes para viabilizar sua altíssima produtividade fonográfica. Apesar de não ter um home studio, ele afirma que tem seu esquema para lançar os discos.

“Gravar um disco é sempre um negócio difícil, não vou falar que é um negócio fácil. Na hora que você manda um disco pra fábrica e já arrumou a capa, aí a capa dá problema no arquivo, e autorização, e não sei quê, não sei quê... aí você fala: "Meu, que vendaval, vou ficar 5 anos sem gravar disco agora pra não passar por tudo isso de novo."

Mas, por exemplo, com o Metá-Metá também deu muito trabalho. A gente lançou no virtual, mas a gente lançou naquele esquema dentro do Bagagem de ter um vídeo pra cada música, daí a gente tinha que ficar cobrando vídeo dos artistas, os artistas fazendo vídeo em cima da hora, com data pra lançar, e coisa e tal. Foi uma coisa que deu muito trabalho, o virtual também dá muito trabalho. O disco sempre dá muito trabalho.

Por outro lado, pra mim tá muito mais fácil gravar. Se eu tiver 1.500 reais no bolso eu gravo um disco; o meu preço de estúdio é esse. Entro lá ensaiado, 1234, dois takes pra cada música, depois vou gastar mais um pouco com a mixagem e a masterização e a capa vai estar pronta, a capa pode ser algum amigo que faça e eu dou a grana depois." (Entrevista com Kiko Dinucci, dia 23/04/2012) 
Mesmo sem dominar a parte técnica como Bruno Buarque ou Dustan Gallas, artistas como Kiko Dinucci e Tatá Aeroplano transitam entre técnica e arte, entre os aspectos materiais e imateriais de seu fazer musical, habitam uma região onde os limites entre técnica e arte são indiscerníveis ${ }^{24}$. Eles criam seus esquemas de produção. Esquemas calcados em relações interpessoais de amizade e confiança com pessoas como Bruno Buarque e Dustan Gallas (capazes de mediar com competência a arte e a técnica), calcados em recursos financeiros e materiais próprios (Kiko gravou os discos do Metá-Metá com cachês de shows, Tatá gravou os discos do Cérebro Eletrônico e seu disco solo com recursos próprios e ajuda de sites de crowdfounding como o Catarse), possibilitando uma autonomia criativa quase absoluta. Tatá utiliza a expressão "alforria artística" para falar dessa situação. Esses esquemas autônomos de produção ganharam força nesses últimos anos, justamente pela expansão das tecnologias na área do áudio e pelo aumento do número de donos de pequenos estúdios onde os pacotes de gravação de discos são mais viáveis economicamente. A noção de "grupo sonoro" (BLACKING, 2007) é boa pra pensar essa realidade - essas pessoas compõem ao meu ver um novo grupo sonoro formado por músicos que compartilham alguns elementos importantes: 1 referências musicais, 2 - tecnologias de produção musical, 3 -tecnologias de divulgação e distribuição da música gravada via redes sociais na internet, 4 -a noção de que é fundamental gravar discos autorais, 5- um fazer musical multifacetado onde cada um se comporta como produtor musical em alguma etapa do processo (produtor no sentido de mediador quase xamânico da arte e da técnica). Ao gravarem discos autorais, essas pessoas se realizam enquanto artistas, ou talvez possamos dizer, elas se constituem como artistas.

Os discos podem ser interpretados como obras de arte musicais que tornam pública a agência dos músicos-artistas. Eles são objetos que expõe uma agência, mas que também

\footnotetext{
${ }^{24}$ Eduardo Viveiros de Castro (2006) afirma que o xamã pode ser um estado, uma região de indiscernibilidade entre humano e não-humano, pode ser um substantivo, mas também um adjetivo qualificando uma potencialidade de qualquer individuo. Qualquer um que sonha ou interage com espíritos pode ter essa qualidade de xamã, nem que seja uma vez na vida. Da mesma forma, no caso desses músicos a capacidade de mediação entre arte e técnica é acionada conforme a situação, ora se comportam com músicos-artistas, ora como técnicos em áudio e gravação. O xamanismo é uma boa chave de leitura para uma reflexão a respeito das mediações envolvidas nesse fazer musical. Estamos tratando de dois universos distintos conectados no fazer musical da produção desses discos. Quando Bruno Buarque, por exemplo, discute a forma da música ou os ritmos de bateria está acionando, ou está mais próximo do pólo artístico. Quando ele está operando o software de gravação ou quando está posicionando os microfones para gravar está acionando o polo técnico. $\mathrm{O}$ acesso aos recursos técnicos de gravação de disco pelos músicos, os coloca numa região de indiscernibilidade entre arte e técnica.
} 
agem, transformando a vida dos seus criadores. Alfred Gell (1998), em Art and Agency, traça uma complexa teoria da agência dos objetos de arte que será explorada com profundidade no segundo capítulo. Por enquanto, vale notar que ele é um dos antropólogos que, assim como Latour, presta atenção na conexão entre humanos e não-humanos em suas narrativas de modo mais simétrico indicando a possibilidade dos objetos agirem sobre as pessoas, das obras de arte ocuparem posição de agentes e os artistas a posição de pacientes. Latour (2001; 2002; 2009) nos fornece arcabouço teórico para analisarmos os discos como objetos/sujeitos actantes nas "rede sócio-técnicas" onde estão inseridos. Criticando as divisões constitucionais modernas entre sujeito/objeto, sociedade/natureza, humanos/não-humanos ele afirma:

"Possuímos centenas de mitos contando como o sujeito (ou o coletivo, ou a intersubjetividade, ou as epistemes) construiu o objeto - a revolução copernicana de Kant sendo apenas um exemplo de uma longa linhagem. Não temos, entretanto, nada para nos contar outro aspecto da história: como o objeto faz o sujeito." (LATOUR, 2009: 81)

Os discos fazem os artistas tanto quanto os artistas fazem os discos. As posições não são estáveis, mas sim dinâmicas. Podemos pensar diversas situações e formas de agência do disco sobre o artista. O disco faz o artista ao promover encontros com outros músicos que enriquecem os arranjos de uma canção, ao fazer o nome do artista circular de forma mais ampla (seja na internet, nas mídias tradicionais ou entre os próprios músicos e ouvintes apreciadores), ao dar forma a uma obra musical e apresentá-la ao público, ao servir de impulso para um show ao vivo etc. André Midani (2008), empresário musical mitológico da indústria fonográfica brasileira, tem uma fala reveladora sobre como o disco se torna pessoa e a pessoa se torna o disco no seu livro autobiográfico. Falando sobre quando conheceu João Gilberto e passou a trabalhar na divulgação de seu primeiro disco no final dos anos 50 ele conta o seguinte:

“Assumi pessoalmente a responsabilidade da divulgação de João Gilberto perante as estações de rádio e de TV, e, por assim dizer, fui bater de porta em porta "com o João debaixo do braço" em cada uma delas, falando com seus diretores de programação." (MIDANI, 2008: 80-81).

Ele mesmo colocou aspas no texto original quando escreveu "com o João debaixo do braço", ou seja, com o disco Chega de Saudade debaixo do braço. Quem é o objeto nessa situação, João Gilberto ou o disco? Latour fala em "quase-objetos" e "quase-sujeitos" lançando uma reflexão provocante à posições absolutas das entidades no "acordo moderno." O esforço 
intelectual de sua antropologia é fugir das posições absolutas ${ }^{25}$. Lançando este tipo de olhar aos discos e aos processos criativos envolvidos na sua constituição fica claro sua importância dentre os membros do grupo sonoro analisado aqui.

Vale notar que nem todos gravam discos autorais. Dentro de uma visão mais tradicional, pode-se dizer que disco autoral é o disco onde o artista é também autor do repertório, ou seja, o intérprete é também compositor. Na Ilustrada, da Folha de São Paulo do dia 03/04/2013, por exemplo, uma matéria assinada por Thales de Menezes informava que o astro Rod Stewart estava lançando quatro disco em homenagem aos clássicos da música americana dos anos 20 aos anos 50. Nesse tipo de disco o artista interpreta composições de outros; não é autoral no sentido que estou empregando aqui. Rodrigo Campos grava músicas de sua própria autoria, Kiko e Tatá também. Quando gravam músicas de outros autores, são músicas de amigos próximos, mas isso é raro nos discos lançados entre 2011-2012. Tulipa Ruiz, Criolo, Karina Buhr, Gui Amabis, Rômulo Fróes, Pélico, Rafael Castro, Andréia Dias, Bárbara Eugênia, somente para citar alguns nomes, são exemplos de artistas desse grupo que só estão lançando discos autorais; discos onde o artista é o compositor e intérprete. Essa junção entre compositor e intérprete não é novidade, encontramos ao longo da história da música popular brasileira inúmeros exemplos de artistas que compunham e interpretavam suas obras - desde Noel Rosa a Chico Buarque. O que identifico é, simplesmente, essa junção entre compositor e intérprete como uma característica marcante desse grupo específico. Outra característica marcante são as dinâmicas coletivas de arranjo das canções que representam a possibilidade de ampliarmos a noção de autoral tradicional.

\subsection{Dinâmicas coletivas de arranjo}

Marcelo Cabral é um baixista e produtor musical respeitado na cena musical atual. Ele produziu o disco Nó Na Orelha do rapper Criolo, considerado pela crítica especializada uma das novas revelações da música ${ }^{26}$ e um artista com um público em expansão pelo Brasil.

\footnotetext{
${ }^{25}$ Latour localiza nas controvérsias dos mais variados tipos o grande campo a ser estudado. Ele busca a região quente das grandes discussões contemporâneas onde os fatos não se fecharam em caixas de pandora estáveis. Ele estuda, em diversos textos $(1983 ; 2000 ; 2001 ; 2002 ; 2009)$, as instabilidades das verdades e fatos da ciência como grande mitologia dos modernos. Mostra que os fatos são fabricados e reais ao mesmo tempo abrindo caminho para um realismo construtivista, ou se preferirmos, um construtivismo realista, tanto faz.

26 “Autor do disco mais elogiado do ano, incensado pela crítica e por uma devota massa de fãs, indicado a cinco prêmios no VMB, shows abarrotados. Criolo está por cima, não se discute. Mas o seu
} 
Cabral é um dos interlocutores dessa etnografia porque trabalha com Rodrigo Campos e com Kiko Dinucci em várias situações. Ele gravou o disco Bahia Fantástica, faz parte do MetáMetá ( grupo liderado por Kiko Dinucci, Juçara Marçal e Thiago França), e é membro do Passo Torto (grupo formado por Cabral, Kiko Dinucci, Rodrigo Campos e por Rômulo Fróes). Durante um ensaio preparatório para a gravação do segundo disco do Passo Torto, ouvi Cabral dizer uma das frases mais interessantes sobre produção musical.

"Quanto menos pronta a canção chega, mais legal é de produzir. Quanto mais pronta, com melodia, harmonia, refrão, mais difícil é!"

Essa fala revela um característica importante dos processos de produção musical que pude observar durante a pesquisa - o caráter coletivo dessa produção. Essa geração de músicos estabeleceu uma dinâmica coletiva de produção musical bastante peculiar. Quanto menos pronta a canção de um indivíduo chega, mais os outros podem criar e acrescentar. Os arranjos dos discos são criados coletivamente, todos dão ideias, todos se comportam como se não fossem apenas responsáveis pelo seu instrumento, a figura do instrumentista é suplantada pela figura do produtor musical e do artista. Cada envolvido é também artista e autor, mesmo quando o disco leva o nome de um só, ele é de vários. Rodrigo Campos em seu Bahia Fantástica deixa claro no encarte do disco que a produção musical e os arranjos são de todos. Estamos falando aqui de uma noção de autoria ampliada. Em uma entrevista na sua casa no bairro de Pinheiros em São Paulo ele comentou:

"Então agora, eu estou fazendo de um jeito diferente, um jeito mais coletivo, eu estou dirigindo a parada, mas de uma maneira sutil, chamei o Rômulo Fróes para dirigir junto comigo e montei uma banda. A banda são os produtores - então cada um dos músicos vai dar a contribuição, a gente vai gravar ao vivo... É um jeito que eu ainda não vi ser feito dos músicos assinarem a produção mesmo." (Entrevista com Rodrigo Campos, dia 25/05/2011).

Tatá Aeroplano também reconhece que seu disco é de todos e promete revolucionar a questão dos direitos autorais de suas canções, passando um percentual de autor para todos os músicos.

o sucesso é tudo, menos repentino. Está apenas colhendo os frutos de mais de 20 anos de rap -e 35 de uma dedicada e improvável história de educação em família." (Trecho inicial de material publicada pela revista Trip, no 203, Setembro de 2011). 
Ele se mostra bastante satisfeito e feliz com o resultado sonoro do disco. Em sua opinião, Dustan Gallas, Junior Boca e Bruno Buarque souberam respeitar suas canções, eles "ouviram as canções, entenderam as histórias que elas contavam.” Boa parte do que pude observar nos dois dias que passei com esses músicos se resumiu à audição das canções e à adição de camadas a partir da compreensão coletiva da estrutura dessas canções. Antes de gravar cada canção, eles ouviam juntos as guias que Tatá gravara somente com voz e violão para então iniciarem o trabalho de produção. Ficou claro durante esses momentos que o músico antes de começar a gravar tem que se comportar como audiência. Quanto menos músico e quanto mais audiência ele for, mais se aproximará do artista; seu trabalho de produção da canção, propriamente dito, terá mais resultado. Os discos gravam os artistas e transformam músicos em audiências. Essa audiência também se comporta como um artista quando passa a construir coletivamente a canção refletindo sobre os conteúdos poéticos-sonoros junto com o compositor original.

A dinâmica deste trabalho, apesar de dirigida por Dustan Gallas e o próprio Tatá, foi bastante coletiva na medida em que todos davam ideias e sugestões de arranjo musical. Esses arranjos não eram escritos em partituras, as ideias eram experimentadas e gravadas em novas versões guias conforme iam surgindo. Não existe separação clara entre arranjador, intérprete, compositor, instrumentista. As fronteiras entre essas categorias são permeáveis entre si, elas se interpenetram mesmo mantendo zonas de heterogeneidade; talvez a que permaneça mais intacta e "pura" seja a figura do compositor, mas Tatá Aeroplano insiste que seu disco é de todos, ele inclui os músicos como coautores das canções ${ }^{27}$. Essa noção de arranjo que emerge na observação do fazer musical desse grupo é bastante particular se comparada a uma visão mais acadêmica e tradicional.

"O estudo do arranjo muito tem a ver com o da composição: ambos dependem de matérias teóricas fundamentais: a harmonia, o contraponto, a morfologia e a instrumentação (sem falar do permanente objetivo, que todo músico deve ter, de aprimorar seu ouvido até níveis cada vez mais avançados de percepção).” (ALMADA, 2010: 17).

\footnotetext{
${ }^{27}$ Morelli ([1991] 2009) mostrou como os músicos eram um dos grupos de trabalhadores da indústria fonográfica mais desvalorizados. Aos músicos sempre cabia a menor parte de todo montante, sendo que nos primórdios da indústria eles recebiam pagamentos por serviços prestados como "trabalhadores comuns". Historicamente, os músicos foram os últimos a serem incluídos nas receitas obtidas com direitos autorais (recebendo a menor parte, os chamados "direitos conexos") e a serem reconhecidos como "trabalhadores artísticos".
} 
Este trecho retirado da introdução de um livro formal de arranjo, do professor da UFRJ Carlos Almada, indica uma necessidade de conhecimentos teóricos que nem sempre estão presentes entre os membros desse grupo. Quando alguém vai estudar arranjo na universidade, está implícito que estará lidando com grandes massas instrumentais que exigem amplo conhecimento teórico, e "o arranjador deve desenvolver, por meio da experiência pessoal e de muitas análises" (ALMADA, Ibidem: 343) uma noção de forma, de equilíbrio e de como empregar bem cada instrumento. $\mathrm{O}$ arranjador tradicional é um expert em instrumentações volumosas. Os arranjos devem ser escritos numa partitura e normalmente são uma criação individual. Cirino (2009) apresenta uma discussão etnomusicológica interessante sobre a questão dos arranjos na música instrumental popular brasileira, mostrando como os arranjadores desse universo se equilibram entre o erudito e o popular, entre a partitura escrita e os espaços para improvisação (marca distintiva desse universo instrumental popular). Mesmo com espaço para improvisação, a noção de arranjo que Cirino apresenta está ligada ao indivíduo e à partitura escrita, ou seja, quem assina os arranjos na maioria das vezes é uma pessoa só e não um grupo, e essa pessoa escreve suas ideias em partituras que serão lidas e executadas por instrumentistas com grande competência técnica. Quando os músicos analisados aqui falam em arranjo, estão tratando de um outro tipo de arranjo. Um arranjo que é coletivo, não exige domínio teórico profundo, não opera com instrumentações volumosas, não opera com partitura escrita. A única característica desse grupo próxima da concepção de Almada é a percepção auditiva avançada, uma característica forte em músicos que não trabalham com partitura.

Essa dinâmica de arranjos coletivos predominou no processo de criação do disco Bahia Fantástica $^{28}$, do disco Metal Metal, do disco Tatá Aeroplano e do Passo Elétrico entre outros. Eu mesmo pude experimentar, como músico, participar de uma gravação de disco ${ }^{29}$ junto de Kiko e Rodrigo, em Julho de 2012, onde a dinâmica de criação de arranjos das canções ocorreu dessa forma. É um modo de produção que esse grupo sonoro encontrou para trabalhar as canções inéditas de cada compositor. Um modo de produção que funciona sem arranjos pré-concebidos individualmente por um arranjador de fora, funciona com base na amizade e

\footnotetext{
${ }^{28}$ Com a exceção de pequenos trechos de arranjos escritos para cordas elaborados individualmente por Marcelo Cabral em algumas canções, todo resto do processo foi baseado em dinâmicas coletivas de arranjo.

${ }^{29}$ Disco Eslavosamba de Cacá Machado. Esse disco mesmo contando com uma dinâmica bastante coletiva de arranjos teve a produção musical assinada por Guilherme Kastrup, diferentemente de Bahia Fantástica, onde todos músicos da banda assinam a produção.
} 
confiança que cada músico estabelece com o outro. Um modo de produção que se estabeleceu em parte por uma questão de necessidade, como afirma o compositor Rômulo Fróes, que participou do $2^{\circ}$ disco de Rodrigo Campos, Bahia Fantástica, num vídeo divulgado no youtube:

“O convívio com os outros artistas foi necessário. Você até pode fazer seu disco inteiro lá na sua casa, mas enfim qual a graça que tem isso , né?! Compartilhar a sua música e mostrar a sua música pro outro artista e querer que esse outro artista contribua pro seu trabalho, além da coisa óbvia de admiração por esse outro artista, tem a coisa da necessidade mesmo! Olha, eu toco violão no seu disco, você toca bateria no meu, eu faço uma letra pra você, pra sua canção e você canta no meu disco. É isso, vamos aí, vamos fazer essa coisa juntos, porque eu tô precisando de um baterista e eu não tenho dinheiro pra pagar um baterista, mas eu toco violão pra você! Então, tem uma necessidade de sobrevivência em cima de tudo isso que acabou gerando mais tarde amizades e identidades artísticas." (trecho da fala de Rômulo Fróes no documentário sobre a produção do disco Bahia Fantástica disponível no endereço eletrônico: http://www.youtube.com/watch?v=65MWP qDcx0)

$\mathrm{Na}$ própria fala reproduzida acima percebe-se como as categorias se borram no discurso nativo. Rômulo começa falando na necessidade dos artistas se ajudarem e termina falando do baterista que ele precisa para gravar. Os instrumentistas aparecem como artistas e vice-versa. Entretanto, vale colocar que esse modo de produção musical que estou chamando de coletivo não é grande novidade nas gravações de disco. Não é que esse grupo de artistas está inventando um jeito coletivo de fazer música. Se pensarmos no surgimento do Jazz, grandes discos foram gravados de forma improvisada e coletiva sem arranjos pré-concebidos. Ou mesmo na história do Rock veremos que várias bandas surgiram de grupos de amigos que compunham e criavam coletivamente. Essa dinâmica coletiva de criação é uma característica desse grupo, apesar de não ser uma invenção dele ou uma marca única que o distingue de outros grupos sonoros. O que pode distinguir esse grupo é essa dinâmica coletiva aliada a um domínio tecnológico inédito dos meios de gravação de áudio - um curto circuito entre a parte artística e a parte técnica ${ }^{30}$. Não existem mais intermediários entre uma ponta e outra, esses

\footnotetext{
${ }^{30}$ Devo essa ideia/insight de "curto-circuito" entre arte e técnica ao antropólogo Pedro Augusto Lolli que em vários momentos me auxiliou com suas leituras das primeiras versões deste texto. Stélio Marras me alertou para o caráter destrutivo que a noção de curto-circuito carrega. Realmente, estamos
} 
jovens artistas dominam as principais etapas e se localizam numa região ambígua e indiscernível no meio dos processos criativos e produtivos.

A necessidade de gravar um disco promove encontros musicais que podem virar grandes amizades e parcerias. Os membros da banda Passo Torto são grandes amigos que, segundo Cabral, se encontram quase todos os dias. Essa intimidade na vida transborda para a música gravada em seus discos. Essa amizade transparece na facilidade com que criam arranjos novos para canções inéditas. Gravar um disco é um encontro, é um ritual, é o momento de buscar estéticas novas e ultrapassar o que já foi feito antes. No caso desse novo disco do Passo Torto, esse encontro tem o respaldo financeiro dos recursos arrecadados via projeto aprovado pelo ProAC ${ }^{31}$. A banda conseguiu aval institucional do governo estadual para realizar esse ritual de experimentação e criação musical que o disco representa. Esse apoio garante uma dinâmica de trabalho autônoma, onde os artistas criam livremente sem a interferência de uma gravadora, sem a preocupação de produzir um material repleto de hits.

Um aspecto importante que essa fala de Rômulo Fróes revela, é que cada pessoa envolvida no projeto de um disco se sente como artista. Cada instrumentista tem uma postura criativa com seu instrumento que busca transcender o aspecto técnico da execução. Para ser artista não basta ser um bom instrumentista, para ser artista é necessário "pensar a música" segundo Rodrigo Campos, é necessário "pensar o mundo" segundo Kiko Dinucci. Pode-se dizer que o discurso desse grupo concebe o artista como aquele que pensa o mundo através da música. Kiko entende que o instrumentista pensa somente em música, e "as vezes tem uma visão muito limitada”. Essa ideia vai ao encontro ao que o próprio Blacking (2007) fala sobre leigos e músicos citada logo no início do capitulo.

\subsection{Cardeal 2.100 - Passo Torto}

tratando da lenta sdestruição de um sistema de produção fonográfica implantado pelas grandes gravadoras marcado pelo monopólio dos meios técnicos de gravação.

${ }^{31}$ ProAC é a sigla para Programa de Acão Cultural, uma iniciativa do governo do Estado de São Paulo instituída pela Lei 12.268 de 20/02/1996. Dentre os objetivos do ProAC estão: Apoiar e patrocinar a renovação, o intercâmbio, a divulgação e a produção artística e cultural no Estado; Preservar e difundir o patrimônio cultural material e imaterial do Estado; Apoiar pesquisas e projetos de formação cultural, bem como a diversidade cultural; Apoiar e patrocinar a preservação e a expansão dos espaços de circulação da produção cultural. 
Outro exemplo dessa dinâmica coletiva de arranjos pude observar junto ao grupo Passo Torto. Entre Janeiro e Fevereiro de 2013, eles começaram a ensaiar as composições do novo disco num pequeno estúdio em Pinheiros, na rua Cardeal Arcoverde, 2.100. No início de cada ensaio, eles partiam da canção original tal qual o compositor (ou compositores) criara isoladamente; seria o equivalente da versão guia que Tatá Aeroplano gravara em casa antes de gravar seu disco. Rômulo Fróes estava cantando uma canção sua com violão, quando foi interrompido por Marcelo Cabral.

"Cabral: Isso tá soando muito bossa-nova. Esses acordes...

Rômulo: Bossa-nova?

Cabral: É, bossa-nova. Só de por esse acorde já soa bossa-nova. Experimenta cantar sem tocar e deixa só a gente tocar.“

A composição original de Rômulo Fróes foi feita apoiada em acordes que na opinião de Cabral soavam como acordes característicos da bossa-nova. $\mathrm{O}$ acorde é um sujeito importante aqui, ele determina o estilo da canção que Rômulo apresenta. A bossa-nova foi influenciada pelo jazz, possui uma harmonia sofisticada, os acordes são carregados como sétimas e nonas; trata-se de uma característica estética desse movimento. Segundo a musicóloga Martha Tupinambá de Ulhôa, a bossa nova "permite variações de uma melodia, onde a harmonia é refinamento; o jazz permite a criação de novas melodias, desdobramentos de uma estrutura harmônica básica. Os esquemas harmônicos do jazz, exatamente para possibilitar improvisação são bem mais simples que os da bossa nova.” (ULHÔA, 1997:94)

O Passo Torto em busca de uma estética própria quer fugir dessa harmonia extremamente refinada que marcou a bossa-nova, por isso a preocupação de Cabral (o disco é o momento da definição estética). Kiko e Rodrigo concordam com Cabral e todos partem para uma releitura coletiva da canção original. Nessa releitura, eles falam pouco e tocam muito, o discurso nãoverbal claramente se sobrepõe ao discurso verbal no momento da criação. Todos começam a experimentar riffs e frases melódicas sem uma preocupação rígida com a harmonia inicial. Eles conversam através de melodias. Kiko e Rodrigo ficam experimentando riffs nas suas guitarras até conseguirem "encaixar" bem um no outro. Esse encaixe de riffs forma uma base particular para a canção que fora tocada inicialmente no violão com acordes típicos da bossanova. 
Vale reforçar essa característica desse fazer musical - nos momentos de criação dos arranjos os membros do Passo Torto verbalizam pouco suas ideias, eles simplesmente tocam as ideias em seus instrumentos. Rodrigo Campos e Kiko Dinucci tocam suas ideias melódicas em suas guitarras, Marcelo Cabral no baixo acústico e Rômulo Fróes no violão. Sem conversar muito, eles experimentam melodias tentando encaixar uma na outra. É quase uma improvisação coletiva; uma improvisação com um objetivo comum - arranjar uma canção para um disco. Quando alguém sente que surgiu algo legal ou, ao contrário, que algo não está legal, fala a respeito. Depois de tocar trechos de uma nova canção por alguns minutos e encontrar uma base comum, Cabral verbaliza uma ideia.

“Cabral: Porque a gente não faz algo meio atonal aqui pra chamar a transição pra parte $\mathrm{B} ?$ ?

Kiko: Legal, tipo isso (toca na guitarra uma frase atonal)

Cabral: É, qualquer coisa, daí a gente breca e volta pro tom.

Rodrigo: Como é?

Kiko: Toca qualquer coisa e breca junto! (risos)

Cabral: A gente pode fazer a intro assim também, vai ficar legal!"

A ideia de Cabral representa uma fuga da tonalidade da música. Ele propõe uma transição instrumental onde convida os outros a tocarem qualquer nota sem preocupação com a harmonia original. Esse tipo de recurso causa um choque, traz um ruído para a composição. $\mathrm{O}$ choque atonal valoriza a volta ao tom num momento posterior. $\mathrm{O}$ processo de arranjar a canção passa pela criação desses ruídos, pela criação de transições instrumentais que o compositor originalmente não imaginava. Os outros músicos vão se apropriando da autoria da canção, tanto quanto o compositor original que trouxe o esboço inicial para o ensaio.

Pude acompanhar a banda arranjando três canções durante duas tardes de ensaios. No primeiro dia, eles arranjaram duas canções que Rômulo Fróes estava cantando. No segundo dia, arranjaram uma nova música de Cabral com letra de Kiko Dinucci. As canções de Rômulo possibilitaram uma desconstrução maior, ou seja, possibilitaram mais experimentação nas melodias das guitarras e do baixo acústico. A canção nova de Cabral e Kiko estava com as partes mais fechadas, estava mais pronta. 
De modo geral, todas as canções são estruturadas em parte A e parte B. O ensaio girou em torno de desconstruir as bases harmônicas originais do compositor, de criar transições de uma parte para a outra, criar introduções e finais para as canções. Kiko e Rodrigo dialogam com facilidade com suas guitarras. Eles possuem uma intimidade muito grande. Criaram um estilo próprio de arranjo que se manifesta em outros trabalhos que realizam juntos.

\subsection{El Rocha - Metá-Metá}

Em Junho de 2012, a banda Metá-Metá se reuniu no estúdio El Rocha - que por coincidência também fica localizado no bairro de Pinheiros, Zona Oeste de São Paulo - para gravar seu segundo disco, Metal Metal. O projeto iniciado pelo trio Kiko Dinucci, Juçara Marçal e Thiago França se tornou uma banda maior com a entrada oficial de Marcelo Cabral, Sérgio Machado e Samba Sam. A importância das relações interpessoais de amizade que já foram citadas acima se repete nesse disco. Todos da banda convivem bastante fora dos palcos e dos estúdios. Os arranjos foram feitos nessa dinâmica coletiva com predominância de discursos não-verbais sobre os discursos verbais. Porém, diversamente do que observei no disco de Tatá Aeroplano, onde os arranjos foram feitos durante a gravação, no Metal Metal os arranjos musicais estavam prontos quando iniciaram as gravações. O grupo ensaiou e tocou junto em situações de show e ensaio, antes de entrarem para o primeiro dia de gravação dentro do El Rocha. Vale notar que essa dinâmica de produção é possível também devido à grande qualidade técnica de cada músico. Cada um dos membros da banda toca muito bem seu instrumento e improvisa muito bem. Além disso, essa postura criativa de artista que cada um manifesta ao tocar seu instrumento torna o trabalho coletivo dentro do estúdio muito forte e profícuo. Amizade, confiança, qualidade técnica, postura artística, estética definida são características marcantes desse segundo trabalho do Metá-Metá.

Cheguei no El Rocha de manhã, por volta das 11 horas. Como nas outras situações etnográficas desta pesquisa, justifiquei minha intromissão com a filmadora em punho prometendo compartilhar esse registro com os membros do grupo. Normalmente, os estúdios de gravação são espaços repletos de equipamentos dando uma sensação claustrofóbica, uma sensação de que o espaço físico é pequeno e apertado. Isso fazia com que em diversos momentos eu me sentisse um intruso atrapalhando um momento íntimo da vida daqueles artistas. Eu tentava sempre me acomodar num canto e começava a filmar em silêncio tentando não afetar os processos que ali ocorriam. O fato de conhecer a maioria dos envolvidos de 
antemão amenizava um pouco esse desconforto. Na primeira hora de gravação que presenciei, eles ouviram uma música que haviam gravado no dia anterior. Montaram os microfones para Rodrigo Campos e Thiago França gravarem overdubs $s^{32}$ de cavaquinho e saxofone sobre os outros instrumentos gravados ao vivo. Por coincidência, nesse dia que acompanhei o MetáMetá, Rodrigo Campos, que não é membro oficial do grupo, estava fazendo uma participação especial tocando cavaquinho em algumas músicas do disco.

Depois de uma pausa para o almoço de aproximadamente 1 hora, voltamos todos para o estúdio para continuar gravando. Eles começaram a gravar a música "Logun”. Fiquei filmando na técnica ${ }^{33}$, onde Juçara Marçal gravaria sua voz isolada do resto da banda. Como o próprio título prenuncia, "Logun", nome de um orixá masculino "filho de Oxóssi com Oxum... príncipe do encanto e da magia." (PRANDI, 2001: 137), é uma música bastante influenciada pela sonoridade afro-brasileira. Poderia ser considerada como do gênero "afrobeat", um gênero caracterizado pela repetição de um groove central e pelos ricos arranjos com instrumentos de sopro, mundialmente conhecido devido à obra do artista nigeriano Fela Kuti. "Logun" começa com um violão bastante complexo de Kiko Dinucci fornecendo o cerne do groove, o centro rítmico e tonal da composição. Baixo e bateria entram na sequência dialogando com a levada do violão. Cavaquinho entra fraseando, sendo sucedido por um tema forte de sax. Juçara aguarda, dançando, seu momento de entrar. Após a entrada dos sopros, tudo some novamente restando violão, baixo e bateria. A gravação acontece, dura cerca de oito minutos. Os instrumentos conversam sem parar, os músicos estão todos concentradíssimos para fazer valer esse take da música. Ao término todos deixam seus postos e entram na técnica onde estávamos eu, Juçara e Fernando Sanches, o técnico de gravação e filho do dono do El Rocha ${ }^{34}$.

Ao fim da audição coletiva da gravação que acabaram de fazer, todos comentam que o "erro no final ficou legal". A performance ao vivo de todos está tão boa que eles resolvem que o erro vai se tornar acerto; eles incorporam o erro sem problemas. O erro em questão é uma sobra de bateria e percussão, ou seja, depois que todos pararam de tocar o baterista e o

\footnotetext{
32 Overdub é a gravação de um ou mais instrumentos que é feita separadamente sobre uma base gravada anteriormente. Normalmente se fala em overdub para o que não foi gravado ao vivo.

${ }^{33}$ Técnica é a sala onde fica o técnico de som de uma gravação. Normalmente é onde fica a mesa de som, os pré-amplificadores e os compressores.

${ }^{34}$ Fernando é técnico nessa situação, em outras situações é baixista de bandas de rock. Ele foi baixista da banda CPM22, por exemplo. Isso reforça a ideia de que as posições que essas pessoas ocupam são dinâmicas.
} 
percussionista continuaram tocando algumas notas. Não é raro isso acontecer numa gravação, o erro e o ruído serem incorporados, especialmente em performances ao vivo com vários instrumentos ao mesmo tempo. Isso também é comum em músicas com espaço para improvisação que é o caso de "Logun". No caso da MPIB, Cirino afirma que:

"O erro é sempre lembrado pelos entrevistados como algo relativo, porque abre perspectivas de novas ideias e a partir dele "pode surgir uma outra atitude." Esta nova atitude que incorpora o erro, por um lado, acaba incentivando o instrumentista a se arriscar mais e, por outro, cria o impacto, o susto e o suspense." (CIRINO, 2009: 65).

Tem um momento em que Kiko Dinucci e Rodrigo Campos improvisam variações rítmicas em seus instrumentos que dificilmente poderiam ser reproduzidas da mesma forma novamente. Se eles optassem por não utilizar esse take, perderiam esse diálogo.

“Kiko Dinucci: Sempre dá certo, eu faço qualquer coisa que dá certo (falando sobre as levadas rítmicas que tocou).

Rodrigo Campos: Parece briga de galo! (risos)

Fernando Sanches: Fazer overdub ia ficar estranho!

Kiko Dinucci: Tem que ser os dois juntos."

Vale notar aqui como o vocabulário musical fornece agência aos instrumentos e às notas tocadas. Neste trecho, Rodrigo Campos brinca que as melodias do cavaquinho e do violão parecem galos brigando. Em outros momentos, os músicos falam das frases da guitarra, dos instrumentos dialogando, conversando. Na minha experiência como músico é comum falar dessa forma quando nos referimos aos instrumentos e às melodias que tocamos neles. Por exemplo, se você criou uma melodia no baixo e quer que o guitarrista toque a mesma melodia com você, é muito mais comum dizer "toca essa frase comigo", ao invés de dizer, "toca essa sequência de notas comigo", ou algo do tipo.

O El Rocha é um estúdio bastante requisitado na cena musical de São Paulo. Uma prova disso é sua agenda lotada, para se marcar uma gravação nesse estúdio deve-se esperar de um a dois meses para conseguir horário. É bem maior e mais antigo que o Minduca de Bruno Buarque, e conta com uma infraestrutura mais complexa. Possui pelo menos quatro salas separadas de gravação o que torna possível grupos como o Metá-Metá gravarem suas performances ao vivo. Nesse dia, na sala maior estavam Sérgio Machado na bateria, Samba Sam na percussão 
e Marcelo Cabral no baixo elétrico. Em pequenas salas isoladas acusticamente estavam Rodrigo Campos tocando cavaquinho, Thiago França no saxofone e Kiko Dinucci com violão acústico de nylon. O estúdio permite que todos toquem juntos, mas para isso tem que isolar o som de cada instrumento, o que no caso dos instrumentos acústicos representa uma necessidade de isolamento fisico. Eles tocam juntos, porém separados. O estúdio carrega essa contradição; separar o que está junto e isolar acusticamente o que deve soar coletivamente ao final do processo. Para que Kiko e Rodrigo possam conversar com seus instrumentos, eles estão conectados pelo que escutam em fones de ouvido; fisicamente, estão separados em pequenas salas. Se Kiko e Rodrigo se escutam "sempre dá certo"; tudo que um toca, o outro responde e vice-versa.

Essa característica de isolamento acústico que um estúdio possui é fundamental para a manipulação sonora que uma gravação de disco exige. O som para ser manipulado deve ser capturado de forma isolada, dito de outra forma, de forma pura. Cada instrumento é "purificado" para depois ter seu som manipulado com todos recursos tecnológicos disponíveis. Esse tipo de operação calcado na purificação e isolamento de agentes lembra muito o que ocorre dentro de laboratórios científicos como nos lembra o trabalho de Marras (2009).

\subsection{YB Music - Bahia Fantástica}

De todos os estúdios que frequentei durante a etnografia, nenhum é tão grande quanto os estúdios da YB, onde Rodrigo Campos gravou seu $2^{\circ}$ disco, Bahia Fantástica. Além de estúdio, a YB é um dos selos paulistanos que mais se aproxima de uma gravadora; eles possuem uma infraestrutura física e técnica de alta qualidade. Possuem excelentes profissionais e costumam lançar artistas desconhecidos em troca da edição das músicas ${ }^{35}$; eles fornecem o estúdio e os profissionais de gravação, e o artista cede uma porcentagem das edições das músicas gravadas. É um pacote apreciado por muitos músicos e não tão apreciado por outros. Aqui não nos cabe detalhar esse acordo entre a YB e os artistas. Por enquanto, vamos descrever em detalhes os dois dias de gravação do Bahia Fantástica que pudemos presenciar e filmar.

\footnotetext{
${ }^{35}$ Entre novos artistas que lançaram discos pela YB, estão nomes como Tulipa Ruiz e Rômulo Fróes (já não tão desconhecidos assim), Passo Torto, Dudu Tsuda, Bruno Morais, Pélico, Pipo Pegoraro entre outros.
} 
Dia 4 de Outubro de 2011, saí de uma aula de antropologia da pós-graduação na USP por volta das 15 horas, rumando para os estúdios da YB, na rua Purpurina, 434, na Vila Madalena. Quando cheguei fui muito bem recebido pelo próprio Rodrigo Campos. Todo equipamento estava montado e todos membros da banda posicionados - Maurício Fleury nos teclados, Marcelo Cabral no baixo elétrico, Kiko Dinucci na guitarra, Maurício Takara na bateria e Thiago França no saxofone. Todos chegaram bastante ensaiados, as músicas fluíam com rapidez. Gravavam duas ou três versões no máximo de cada música; Thiago França e Maurício Fleury faziam alguns overdubs e finalizavam as bases. Rodrigo colocava sua voz num momento posterior, quando a banda já havia escolhido seus melhores takes. Meses antes, Rodrigo me contara um pouco da pré-produção desse disco.

"A gente fez 6 ou 7 ensaios até agora e levantou 5 músicas. As músicas estão boas para gravar, a gente vai fazer mais 2 ensaios e vai gravar. Então serão 9 ensaios para 5 músicas. Só que o disco não vai se encerrar nesse ao vivo, né?! Esse ao vivo vai ser a base pro Lenza, o Lenza está também, o Lenza vai editar, a gente vai ter ideias juntos..." (Entrevista com Rodrigo Campos, dia 25/05/2011).

Lenza foi o técnico de som operando os equipamentos da YB durante toda gravação. Considerado um excelente profissional nesse meio musical, Lenza trabalha com diversos artistas. Ele possui um estúdio próprio que utiliza somente para mixagens. Os estúdios da YB são propriedade de três sócios, é um ambiente menos caseiro que o Minduca de Bruno Buarque. Entretanto, existe uma constante na produção de todos esses discos que citei ao longo do capitulo: a liberdade que cada um tem de manifestar suas ideias a respeito do trabalho. Essa liberdade está ligada ao que chamei de dinâmicas coletivas de produção musical numa situação de curto circuito entre técnica e arte. Todos manifestam ideias, todos pensam a canção juntos, todos assumem uma responsabilidade artística maior do que a de um instrumentista e de um técnico de som profissional. Observamos o tempo todo instrumentistas e técnicos de som profissionais que transcendem a prática meramente instrumental no sentido técnico de seu trabalho ao pensarem a música como um todo. 


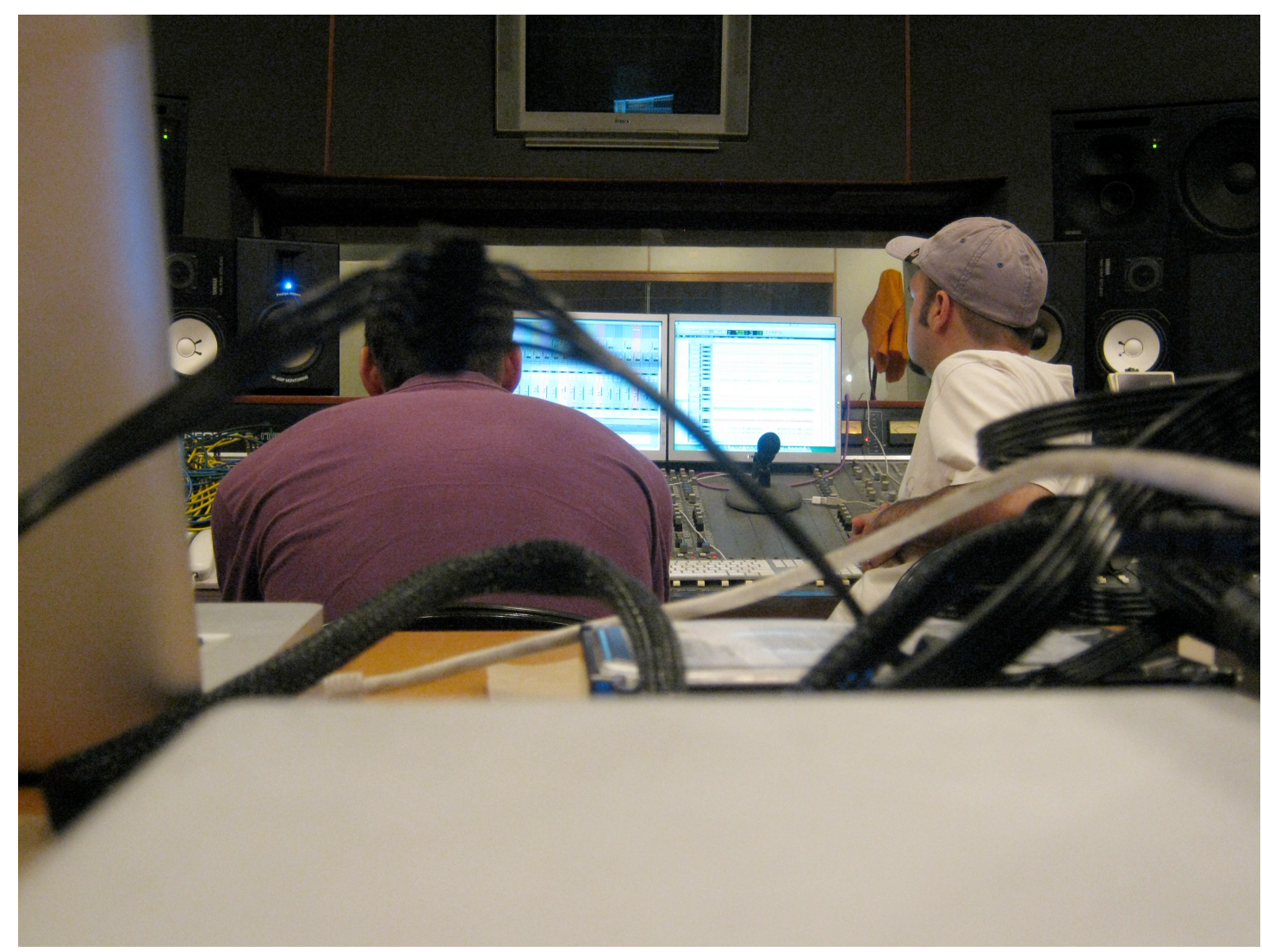

Gustavo Lenza (de boné) na YB durante as gravações do Bahia Fantástica

Passando o som para gravar a música "Sou de Salvador", Maurício Fleury pergunta se alguém tem uma sugestão de timbre. Maurício Takara sugere uma mudança de andamento. Eles gravam um take e vão para a sala técnica ouvir.

"Takara: Quanto tempo tá?

Lenza: Tá com três minutos.

Takara: E o andamento, que você achou?

Lenza: Eu gostei desse. A única coisa que achei é que a música vai direto, não tem respiro.

Takara: Até por isso eu achei que esse andamento fica um pouco menos TchacaTuku TchacaTuku TchacaTuku, o tempo inteiro!

França: Na verdade, essa música pode ter 3 minutos ou 20, você escolhe!

Takara para o Lenza: Mas você acha que a gente devia dar uma saída, tirar a mão um pouco. Eu fiquei com essa dúvida nos ensaios.

Cabral: Podia dar uma picotada não mão depois!

Takara: Tem o lance hipnótico disso que é legal também. 
Lenza: Mas aí você segura, se você e o baixo segurarem, o teclado e o baixo podem dar essa dinâmica.

Fleury: A gente tinha pensado também de fazer uns barulhinhos, a gente tinha conversado de fazer uns climas... uma guitarra a mais ou uns efeitos...

Rodrigo: Vamos dar uma tocada. Se a gente achar que tem que pós-produzir, depois pensa alguma coisa a mais!”

Pós-produzir nesse caso tem um significado próximo de overdub, é gravar ou editar trechos depois que a banda base gravar sua parte ao vivo. Nos dois dias que fiquei dentro do estúdio, as bases de baixo, bateria e quase todas as guitarras foram gravadas ao vivo. Os instrumentos que mais realizaram overdubs foram o sax e o teclado, até porque eles mexem com mais timbres diferentes, sobrepõem camadas e vozes com timbres diversos. Trouxe esse diálogo entre os músicos, por servir como mais um exemplo de como as ideias de arranjo são discutidas coletivamente por todos da banda, inclusive pelo técnico de som Lenza, que acaba falando mais do que alguns músicos nesse momento ${ }^{36}$. Também vemos como termos de outras esferas da vida contaminam as falas humanizando a música que não têm respiro, que pode ser picotada, que desperta um lance hipnótico. Fleury fala em trazer para a música uns barulhinhos que ao serem incorporados deixam de ser barulhinhos e se tornam efeitos que constroem o clima da música.

Esse foi um dos diálogos mais extensos que presenciei sobre dúvidas de arranjos no Bahia Fantástica. A banda estava bem ensaiada e bastante segura sobre o que iria executar na hora da gravação final. Restaram poucas coisas para serem discutidas dentro do YB, mas mesmo tendo realizado vários ensaios, algumas dúvidas surgem na hora de gravar o disco. Aqui, a dúvida principal é qual o andamento ideal para a canção. $\mathrm{O}$ andamento é a velocidade da música, por isso se costuma dizer que tal música tem um andamento rápido ou lento.

"A terminologia tradicional associa o ritmo à categoria do andamento, que tem sua medida média no andante, sua forma mais lenta no largo, e as indicações mais rápidas associadas já à corrida afetiva do allegro e do vivace (os andamentos se incluem num gradiente de disposições físicas e psicológicas).” (WISNIK, 2005:19) ${ }^{37}$.

\footnotetext{
${ }^{36}$ Sugerindo novamente a região de indiscernibilidade que os membros desse grupo sonoro habitam.

${ }^{37}$ Wisnik associa o pulso musical aos pulsos corporais, o ritmo aos andamentos do caminhar humano. Para um discussão mais detalhada ver o tópico Periodicidade e Pulso, Wisnik (2005).
} 
Ao gravar uma canção é necessário definir o andamento; é uma escolha importante e que influi no ritmo da música. Podemos perceber que quem fica mais preocupado com essa questão é o baterista Maurício Takara. Cada andamento implica numa maneira diferente de tocar a bateria. Interessante notar a fala de Maurício Takara quando ele tenta imitar o som da levada de bateria com a boca. É um discurso verbalizado, porém em forma de onomatopeia ao lado das falas normais; os dois juntos expressam ideias do músico sobre o arranjo. Ele utilizou a onomatopeia porque estava sem a bateria na hora ${ }^{38}$. Provavelmente teria tocado o TchacaTuku TchacaTuku TchacaTuku que cantou com a boca se estivesse sentado na frente da bateria.

A forma como Lenza se coloca no diálogo não o diferencia tanto do próprio Rodrigo Campos e vai de encontro ao curto circuito que tem se caracterizado como fundamental no fazer musical desse grupo sonoro. Mesmo sendo o responsável técnico da captação do áudio do disco, ele opina sobre a parte musical do arranjo quando fala que "a música não respira", talvez a frase menos técnica de todo esse diálogo, a frase que mais humaniza a música. Ele pende mais para o lado técnico mas não se restringe a ele. Apesar de não tocar nenhum instrumento nessa gravação, ele atua como produtor musical do disco tanto quanto os músicos; é também um grande mediador. Nos créditos da contracapa do disco, seu nome é o primeiro da lista de produtores onde também aparecem todos os músicos da banda.

\section{$2^{\mathrm{a}}$ Parte - De casa para o disco - Da canção bruta à canção produzida}

Vamos analisar agora, a canção "Perigas Correr", 2a faixa do disco Tatá Aeroplano, e acompanhar as transformações que ela sofreu da casa do artista até ser inscrita no disco dentro do estúdio Minduca pelos músicos que participaram da gravação. Para realizar a análise temos em mãos os seguintes dados: versão bruta da canção (executada por Tatá somente com violão semanas antes da gravação do disco), etnografia dos processos de produção musical da canção (filmagens e diário de campo dos dias de ensaio e gravação dessa canção no estúdio Minduca), versão produzida da canção (a versão final selecionada para o disco).

\footnotetext{
${ }^{38}$ Para uma refexão sobre a onomatopeia e a linguagem ver "A Capacidade Mimética" de Walter Benjamin (1970). A onomatopeia é uma forma de manifestação do que para Benjamin é uma característica filo-genética dos seres humanos, a capacidade mimética. Aqui, o baterista Maurício Takara tenta mimetizar o som das peças de sua própria bateria; uma mimese de si mesmo.
} 


\subsection{Canção bruta}

\section{PERIGAS CORRER}

(Tatá Aeroplano)

Corro o risco de correr

Corro o risco de correr

Corro o risco de correr o risco

Corro o risco de amar

Corro o risco de correr

Corro o risco de correr o risco de amar

Corro o risco de sofrer

Corro o risco de correr

Corro o risco de correr o risco de amar e sofrer

Corro o risco outra vez

Corro o risco de correr

Corro o risco de correr o risco de amar e sofrer outra vez

Corro o risco por você

Corro o risco de correr

Corro o risco de correr o risco de amar e sofrer outra vez por você

\section{Mas mesmo assim vou correr o risco}

Correr, correr, correr, correr

Acompanhando a trajetória de Tatá Aeroplano de modo mais sistemático desde meados de 2010, minha intenção inicial era escrever sobre sua banda principal na época, o Cérebro Eletrônico. No decorrer dos primeiros meses de pesquisa, Tatá e eu fomos nos tornando amigos cada vez mais próximos. Ele me confidenciou empolgado que iria gravar em breve seu primeiro disco solo. O Cérebro Eletrônico ficaria em segundo plano durante um tempo. Como meu foco era registrar processos criativos que resultavam em discos, 
consequentemente, passei a me concentrar nesse novo disco de Tatá Aeroplano. Numa de nossas conversas, ele me perguntou se eu poderia realizar um registro simples com meu microfone e meu laptop do repertório de seu disco novo. Ele precisava mandar as canções para o produtor musical Dustan Gallas. Dia 5 de outubro de 2011, gravei uma performance ao vivo, na sala de seu apartamento, de Tatá tocando violão e cantando seis músicas de seu ainda inédito disco solo.

Nessa performance ao vivo, ele executou "Perigas Correr", cuja letra transcrevi acima, fornecendo o que estamos chamando aqui de uma versão bruta da canção. Utilizamos bruta no sentido de que não havia sido lapidada ao lado de uma banda, ao lado de um produtor, não havia sido ainda objeto de arranjos e de transformações melódicas e harmônicas. Bruta também no sentido de ter sido gravada com um equipamento bem básico, sem grande qualidade técnica, num ambiente repleto de ruídos e reverberações. No artigo "Modos de Relação com a Música", Luís Melo Campos (2007) trabalha com a noção de música "autêntica" como o som sem mediações tecnológicas, quase uma ideia de som natural.

"Em qualquer caso, ao vivo como em estúdio, os meios técnicos de mediação e manipulação sonora podem ser majorados ou minorados. Em síntese, nos termos em que este estudo utiliza o conceito de autenticidade musical enquanto dimensão analítica, importa sublinhar que a sua valorização significa valorizar as prestações musicais em tempo real reduzindo as mediações tecnológicas ao mínimo indispensável. No limite, o concerto ao vivo seria estritamente acústico e uma gravação em estúdio seria o registro de um concerto sem público. No polo oposto, tem-se a ausência deste tipo de valorização ou mesmo a valorização da manipulação sonora que a tecnologia disponível permite, quer ao nível dos próprios instrumentos musicais, quer ao nível das gravações em estúdio e das atuações em palco. Em termos práticos, significa que uma atuação em palco não é concebível sem a mediação de um sistema de amplificação sonora, e que o trabalho em estúdio se centra mais na manipulação do som do que propriamente no seu registro." (CAMPOS 2007: 95).

No caso dessa versão bruta, a gravação não implicou uma manipulação do som e procurou simplesmente registrar a performance ao vivo do compositor com seu violão. Houve mediação tecnológica, porém a mínima possível. Essa ideia de Campos de que uma performance acústica não possuiria mediação tecnológica pode ser relativizada se tomarmos os instrumentos musicais como instrumentos tecnológicos ${ }^{39}$. Nessa performance registrada no

\footnotetext{
${ }^{39}$ No limite, a única situação musical sem mediação tecnológica seria o canto, a performance vocal onde o único instrumento é o corpo do intérprete. Teríamos então uma técnica envolvida no canto, mas não tecnologia como aquilo que realiza algum tipo de mediação. Campos na verdade está
} 
apartamento de Tatá Aeroplano, estamos próximos do que Campos chama de "autêntico", ou seja, com o mínimo de interferência possível. Essa versão, provavelmente, é a mais próxima possível da primeira versão que o compositor deve ter executado no(s) momento(s) da criação; momento praticamente impossível de etnografar, por acontecer nas situações mais improváveis e íntimas da vida do compositor. O que chamo de versão bruta, está bem próximo do que os músicos costumam chamar de versão guia. Como o próprio nome diz, essa versão guia a banda na hora da gravação oficial. Porém, a versão guia já deve fornecer um mapa, ou uma estrutura final da música, coisa que não acontece nessa versão mais bruta. Quando Tatá cantou em casa, não tinha ainda uma estrutura formal definida.

O que podemos observar nessa performance ao vivo é que cada estrofe da letra se encaixa num ciclo harmônico de quatro compassos formado pelos acordes de Sol Maior (G), Mi Menor (Em), Dó Maior (C) retornando para o Sol Maior (G). Cada acorde dura um compasso quaternário. O tempo de duração total da gravação foi de 2 minutos e 58 segundos. Tatá repete duas vezes a letra inteira, faz um ciclo de violão no meio entre uma repetição e outra. Termina a performance com um vocalize, um solo de voz sem letra sobre 3 ciclos harmônicos completos (12 compassos).

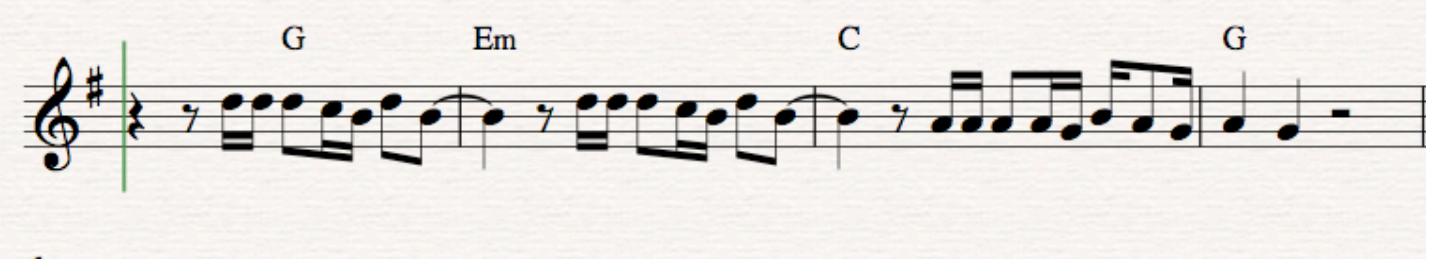

Ciclo melódico e harmônico básico da canção.

Vale notar que mesmo no caso da canção em seu estado mais bruto as novas tecnologias estão presentes. Tatá Aeroplano registra muitas ideias em seu IPhone. Os celulares são capazes de realizar gravações de áudio com qualidade razoável permitindo que compositores registrem seus momentos criativos imediatamente, ampliando a capacidade de memorização. Muitas vezes as canções nem passam pelo papel, elas simplesmente migram de aparelho para aparelho. O guardanapo de papel, amigo íntimo onde os compositores de botequim do século

preocupado em seu estudo em criar instrumentos analíticos para os modos de relação com a música. Ele cria tipos ideais "purificados", como todo bom cientista moderno, para analisar essas relações. Sua noção de mediação é bastante diferente do que Latour compreende por mediação. Entretanto, se levarmos em consideração "As Técnicas do Corpo" de Mauss (2005) e sua ideia de que o corpo humano é o primeiro instrumento técnico que aprendemos a utilizar, não existiria de fato nem canto solo sem técnica. 
passado anotavam seus ímpetos criativos, virou o celular. Do celular para um computador, do computador para um estúdio profissional (Minduca, por exemplo), do estúdio profissional para os discos, e, finalmente, dos discos para computadores pessoais do público do artista. Diana Domingues (1997) fala sobre a simbiose entre homem e máquina na arte do século XXI. "Com as tecnologias, o corpo não mudou em sua configuração biológica. O que se altera é a capacidade da mente de processar informações." (DOMINGUES, 1997: 26). As tecnologias de gravação alteram a capacidade criativa de compositores. Domingues fala num "biológico ampliado", que seria um humano híbrido onde as máquinas estão presentes cotidianamente. "Nós nos fazemos fora de nós mesmos em memórias de máquinas e em propagações do Eu. As tecnologias ampliaram o campo de percepção por novas formas de existir antes não permitidas por um corpo somente biológico.” (DOMINGUES, Ibidem: 26). Os compositores do século XXI existem também em suas ideias musicais digitalizadas em memórias de celulares e computadores.

\subsection{Produzindo a canção}

$\mathrm{Na}$ parte inicial deste capítulo apresentei um diálogo dentro do estúdio Minduca que exemplificou o que venho chamando de dinâmicas coletivas de arranjo. Vimos que uma sugestão de Dustan para Boca era tornar um acorde menor, o que ele chamou de menorizar. Esta foi uma das primeiras alterações sugeridas em relação à versão bruta da canção. A partir daí, várias outras ideias foram surgindo através de discursos verbais (as falas dos músicos) e não-verbais (notas e ritmos tocados nos respectivos instrumentos). Esse momento do processo de produção é muito baseado na improvisação, nada está fechado e definido ainda. Os músicos ouviram a canção bruta e começam a tocá-la pela primeira vez, começam a experimentar levadas rítmicas, ideias melódicas, mudanças harmônicas. Bruno ainda não começou a gravar nada, é o momento de levantar a música, ensaiar, ousar.

Assim que eles terminam de escutar a versão bruta, Dustan propõe para Boca: "E se a gente começar picadinho!?” e toca no baixo arpejos com as notas bem abafadas. Boca e Tatá gostam da ideia, Tatá automaticamente começa a cantarolar uma melodia parecida com a que Dustan acabou de tocar. Bruno, na bateria, começa a tocar junto. Dustan propõe uma variação do Dó Maior para um Dó Menor explicando que é só para mudar um pouco em relação ao original. Tatá propõe que eles façam duas vezes inteiras essa melodia que está se formando como introdução. Dustan dirige um pouco Boca, pedindo que ele toque picadinho junto com a 
linha do baixo, sugere também um efeito de $f u z z^{40}$ para o timbre da guitarra. Boca vai experimentando, encontra um efeito que Bruno comenta com aprovação.

Observando de fora, a criação dessa melodia de introdução é como uma improvisação guiada pela ideia central de Dustan de arpejos picadinhos. Boca e Bruno começam a improvisar em cima da ideia; não é uma improvisação livre, é uma improvisação em busca de uma melodia que se tornará arranjo, que se fixará na canção tornando-se uma parte da própria canção.

"Pode ser dito como um artigo de fé que os improvisadores sempre tem um ponto de partida, algo que eles usam para improvisar em cima. Existem muitos tipos, estendendo de temas, canções, e sequências de acordes até formas, de um vocabulário de técnicas a um vocabulário de motivos e materiais maiores, do que é fácil ou "natural" para as mãos até o que é intelectualmente complexo." (NETTL, 1998: 15-16).

A canção "Perigas Correr" é o ponto de partida para uma prática de improvisação em busca de uma forma final para ser gravada no disco. A ideia de improvisação está ligada à música que não foi pré-concebida, a uma tradição musical aural e não escrita em partitura. $\mathrm{Na}$ musicologia tradicional os estudos da improvisação sempre ficaram em segundo plano segundo Nettl (1998). Entretanto, este mesmo autor indica como é importante iniciarmos estudos mais sistemáticos das práticas de improvisação. Inclusive existe a possibilidade de se pensar a composição musical como algo gerado por práticas de improvisação. Nettl citando H.C. Colles no Dicionário de Música Grove indica essa possibilidade. "Colles insiste, significativamente, que toda composição sem notação surge da improvisação.” (NETTL, 1998: 12). No caso de "Perigas Correr" a composição já estava pronta, mas nossa observação da gravação do disco indica que o arranjo surge de uma postura de improvisar sobre o material sonoro bruto. Essa postura é marcada por um diálogo intenso e ininterrupto entre todos os envolvidos. Todos os músicos tocam e conversam ao mesmo tempo, sugerindo ideias uns aos outros. Quando Dustan começa a explicar muita coisa com palavras é interrompido por Boca que diz: “Toca tu e Bruno, é importante eu ouvir vocês para me encaixar!” Eles tocam a introdução recém criada de um jeito provisório e Tatá começa a cantar a letra. $\mathrm{Na}$ primeira vez, Boca só escuta a levada de baixo e bateria acompanhando a voz. Eles tocam um trecho dessa forma, sem guitarra. Param e fazem algumas observações. Começam de novo, dessa vez com Boca tocando junto, já mais “encaixado" (para usar uma expressão do próprio). O acompanhamento de Boca começa a marcar o tempo 2 e 4 de um compasso quaternário,

${ }^{40}$ Fuzz é um tipo de pedal de efeito utilizado para alterar o timbre dos instrumentos. 
junto com a caixa da bateria. Tudo isso acontece rápido, em 15 ou 20 minutos. Após 30 minutos de trabalho coletivo, a banda já tem um esboço do que virá a ser a versão produzida da canção. As variações melódicas dessa introdução em processo criativo podem ser exemplificadas como segue:

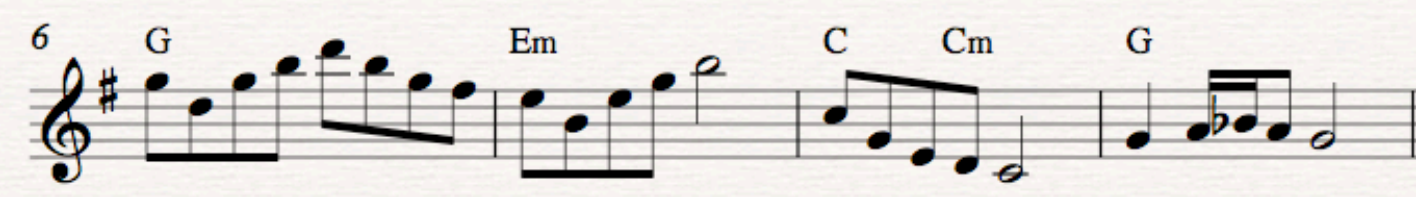

Variação 1

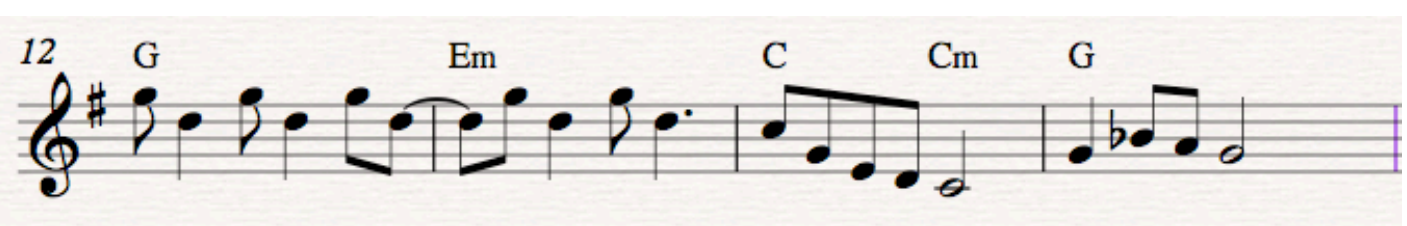

\section{Variação 2}

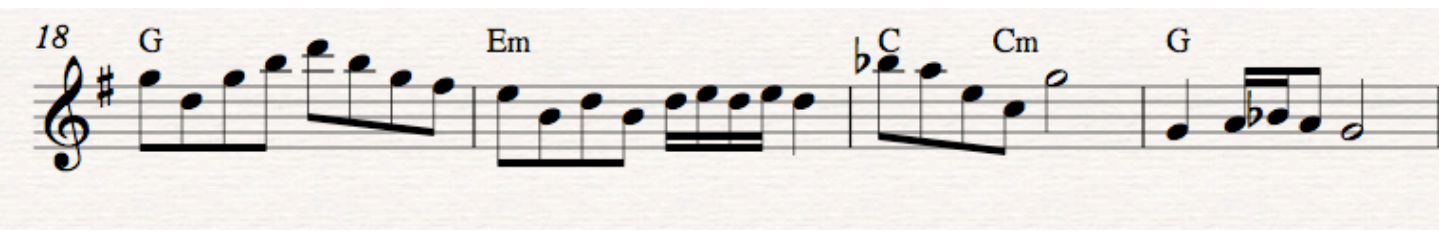

\section{Variação 3}

Essas variações eram tocadas inicialmente de forma livre e improvisada. Junior Boca tocou diversas variações desse tipo até chegar numa versão mais estável. A variação que acabou se estabilizando como tema introdutório da canção foi a terceira transcrita acima. Os músicos passam a chamar esse trecho de melodia de "intro" uma abreviação para a palavra introdução.

"Boca: Podia ficar usando esses dois momentos, canta o primeiro "Corro o Risco" aí voltar para a intro.

Tatá: Seria legal fazer a intro mas o Bruno podia manter a bateria, vocês fazem o tema, mas o Bruno mantém."

Alguns minutos após definirem o tema de introdução, os músicos começam a conversar sobre a estrutura da música, também chamada de mapa. O mapa da versão bruta começa a ser alterado. Antes não havia introdução, nem tema melódico. Agora, a canção passa a contar 
com um tema melódico de introdução que se repetirá no meio, após o primeiro canto da letra. Tatá não está mais tocando violão, está somente cantando. Nesse sentido, ele perde a responsabilidade instrumental da canção transferindo-a para a banda. A banda assume essa responsabilidade, cada músico tem que pensar a música e criar sua contribuição individual. $\mathrm{O}$ artista passa a dividir a criação com os músicos que passam a se comportar como artistas, como criadores de algo tão novo e original quanto a própria canção de Tatá. Essa noção de músico-artista está ligada a esses momentos criativos em que cada um precisa parar e pensar no que irá tocar. $\mathrm{O}$ músico instrumentista normalmente executa ideias que outros criaram e escreveram. O compositor é aquele que pensa essas ideias, cria o que outros no futuro poderão executar. $\mathrm{O}$ artista dentro desse grupo sonoro pode ser visto como o compositor que além de criar, interpreta e executa. Logicamente, todo músico pensa quando toca, mas muitas vezes é um pensamento estritamente musical. O que está em jogo aqui é um pensamento criativo que dialoga com a letra, com a estrutura formal da canção e que tem como pano de fundo a gravação do disco.

"Tatá falando para Dustan: Sabe como é que a gente pode matar essa música? Depois dessa segunda vez, que a gente fez esse refrão, o Boca pode continuar nessa linha de guitarra e só você com o Bruno aceleram e termina.

Boca para todos: Sabe o que é que eu acho, pegando a ideia do Tatá a gente faz do solo essa transposição para essa parte aberta (toca um sol maior na guitarra quando diz aberta).

Dustan: Tipo uma mix das ideias, tipo essa parte que o baixo fica parado... Pegar o baixo parado e botar em outro lugar, né? Senão fica muita coisa.

Bruno: A gente faz o baixo dobrado, não tira ele.

Dustan: Mas aí vai dobrar como?

Bruno: Sei lá, de repente só bota mais notas, a gente começa com um desenho menor ou o baixo já começa dobrado... sei lá! Mas aliar o baixo dobrado com o baixo parado.”

Esclarecendo possíveis sustos, quando Tatá diz matar a música, está falando sobre como finalizar o arranjo. Todos criaram juntos uma introdução instrumental que não existia na canção original e também encaixaram essa introdução no meio da música. Nesta conversa, eles buscavam definir como seria o final da música. Este final foi se constituindo como uma mix de ideias, uma mistura e um equilíbrio das ideias de todos. Dustan propôs um baixo pedal sobre a harmonia da guitarra que continuava girando no ciclo principal (Sol Maior, Mi Menor, 
Dó Maior voltando ao fim para o Sol Maior). Baixo pedal significa uma nota no baixo que se repete enquanto os acordes mudam, cria um efeito de arranjo diferente no final da canção. Quando Bruno fala do baixo parado, é justamente esse baixo pedal. Quando fala no baixo dobrado está se referindo ao ritmo, outro elemento do arranjo. Sobre uma versão inicial da música tocada no violão por Tatá Aeroplano, Dustan, Boca e Bruno inserem uma melodia de introdução (que vira o tema no meio da canção), inserem variações rítmicas, timbres e uma variação harmônica como parte final (onde o baixo fica pedal).

Esse processo observado dentro do Minduca pode ser interpretado como a apropriação coletiva de uma canção por um grupo de músicos que passam a se comportar como artistas ao lado do compositor original. A canção passa a ganhar camadas e partes que o compositor originalmente não podia sequer imaginar. Muitas dessas camadas surgem de improvisos feitos na hora que vão se fixando na medida em que todos aprovam. O trecho final da música surgiu de uma ideia aparentemente simples de Dustan, ele segurou uma mesma nota no baixo, a nota sol, enquanto Boca continuava variando os acordes.

"Bruno: Legal esse final também

Dustan: É porque os acordes podem voltar e eu seguro o Sol. Quer ver? Faz aí Boca os acordes pra ouvir com o baixo parado. (Boca toca a sequência e Dustan mantém o baixo na nota Sol).

Boca: Pô é legal essa ideia! É legal essa ideia em algum momento!"

A partir dessa variação para o baixo pedal, uma série de ideias são colocadas em prática em busca de um trecho final para a canção. Quanto mais eles tocam a canção, mais as partes improvisadas vão se fixando e deixando de ser improvisos, reiterando a ideia de Colles citada por Nettl de que sem notação, é o improviso que gera a composição. O que era experimentação se transforma em arranjo, cada nota passa a ser tocada com mais consciência. Eles repetem o mapa da canção algumas vezes, ao final de uma delas Dustan sugere uma nova parte para finalizar o arranjo.

"Dustan: E esses acordes aqui, eu tô ouvindo isso aqui... (toca uma sequência cromática de notas). Pra fazer só com voz e alguma coisa... Bem "melowzão", bem "umbroso", seria mais uma parte para a música.

Boca: Meio Queen, o Queen agora abriu a ideia. 
Bruno: Vamos passar uma vez essa forma pra ver se faz sentido!"

Ainda como uma última parte do arranjo, Dustan propõe uma sequência cromática de acordes finalizando num Lá Bemol ${ }^{41}$. O Lá Bemol é uma nota estranha nessa harmonia que ficou o tempo todo repousando na tônica de Sol Maior provocando uma leve tensão no final do arranjo. "Perigas Correr" é uma canção que possui uma harmonia circular onde cada movimento começa e termina em Sol Maior. O Sol nesse caso é considerado a tônica. "A circularidade da escala gira em torno de uma nota fundamental, que funciona como via de entrada e saída das melodias, ou, em uma palavra, como tônica, ponto de referência fundante para as demais notas." (WISNIK, 1999: 79). A sugestão de Dustan muda essa via de saída da canção. Nesse estágio dos arranjos - após definirem a introdução, o meio, o final da canção Bruno sugere que já podem gravar a base. O processo todo durou aproximadamente três horas e meia. A partir daqui, a estrutura da versão se consolidou, a banda parte para uma gravação "valendo", isto é, uma gravação que já pode entrar no disco. A base de acompanhamento harmônico, melódico e rítmico se fixou. Cada um já tem uma noção de que notas vai tocar, como vai tocar e onde vai tocar. Dustan e Boca já imaginam os overdubs que farão de guitarra e teclados.

\subsection{Canção produzida}

Acompanhamos o processo de arranjo coletivo da canção "Perigas Correr" até o momento em que se decide que a base está boa para gravar. Todos aprovam a forma, a estrutura, o andamento, a duração e as ideias criadas. Bruno Buarque grava a base de bateria, baixo e guitarra ao vivo, passando todos os sinais de áudio dos instrumentos por uma série de préamplificadores, compressores e conversores. Utilizando um software chamado Logic, Bruno registra o áudio dentro de seu computador. A massa sonora criada pela banda ao vivo é agora convertida num arquivo de informação digitalizada que poderá ser transportado e

\footnotetext{
${ }^{41}$ Uma sequência cromática é caracterizada pela escala formada com todos os semi-tons da música ocidental. Dustan propõe um cormatismo que "é a utilização das melonotas da escala cromática (composta de 12 semitons e uma melonota enarmônica, por exemplo, um 0A (Láb-Mib-Sib-Fá-DóSol-Ré-Lá-Mi-Si-Fá\#-Dó\#-Sol\#)) no contexto de uma composição tonal. Os cromatismos são geralmente estruturados como frases musicais compostas de notas cromáticas, com a intenção de gerar tensão melódica ou harmônica, prolongando o desenvolvimento tonal e adiando a resolução melódica." Extraido dia 21/01/2013 às 13:46 da página: http://www.dicionarioinformal.com.br/cromatismo/
} 
transformado, até chegar no resultado final do disco. Após a captação dessa base ao vivo, os músicos acrescentam os chamados overdubs que são as camadas sobrepostas à base ao vivo num momento posterior. Boca colocou mais uma ou duas guitarras, Dustan colocou camadas de teclados (Farfisa, Fast 4, Mellotron, e Cravo), Bruno acrescentou uma percussão leve e todos cantam no coro final. Este é o momento em que essa geração de músicos se diferencia da geração que viveu o auge da grande indústria fonográfica. Até então, todo processo de criação coletivo de arranjos poderia se assemelhar a uma banda de rock dos anos 80 , ou a um conjunto de jazz dos anos 50. Mas somente com a popularização das tecnologias digitais de áudio, a partir do final dos anos 90 e início dos anos 2000, que esses processos criativos, que já ocorriam, desembocam sem intermediários em discos produzidos de forma autônoma. Esse é o curto circuito entre arte e técnica; os artistas dominando técnicas produtivas que antes eram monopólio da grande indústria, ou no mínimo, eram intermediadas por essa grande indústria. O papel central do disco deixa de ser o de mercadoria.

Para Appadurai (2008) a mercadoria é só um estágio da vida de um objeto; no caso dos discos, um estágio cada vez menos significativo posto que os artistas continuam gravando mesmo com a queda nas vendas e com a proliferação do compartilhamento digital. Appadurai nos convida a pensarmos em mercantilização das coisas e das sociedades. Determinados contextos são mais mercantis que outros, e um objeto experimenta em sua vida social diferentes graus de mercantilização. Ele fala nas "carreiras" dos objetos, e nas fases dessas “carreiras." Fala em "candidatura ao estado de mercadoria." Esse estado de mercadoria dependeria fundamentalmente do potencial de troca do objeto e da resistência que o objeto impõe aos nossos desejos de possui-lo. Ora, num mundo onde a música é digitalizada e circula livremente pelo ciberespaço, onde estaria o potencial de troca de um objeto como um disco? Onde estaria a resistência ao nosso desejo? A canção produzida seria um estágio privilegiado para a obra de um compositor se lançar no mundo das mercadorias, mas o sentido que os artistas deste grupo atribuem hoje a ela transcende essa mercantilização. No caso dos discos pode-se falar em desmercantilização. Os discos não estão acabando, estão se "desmercantilizando", ou (como observou Stélio Marras em sua leitura deste trabalho) se tornando muito mais meios para outros fins mercantis como os shows.

Após a etapa de captação, todos os instrumentos tocados, ao vivo ou não, são mixados. Os volumes, as frequências e os timbres são equilibrados. O passo seguinte é masterizar e prensar o disco. A masterização é um último processamento no material sonoro que chega após a 
mixagem. Está ligada a uma regulagem final de volumes, intensidades e timbres. Esta regulagem final é transferida a um dispositivo chamado master. Normalmente, a mixagem e a masterização são processos realizados por técnicos especializados. Nesse disco, a mixagem foi feita por Bruno e Dustan. Tatá chegou a mandar o material para um técnico de mixagem chamado Kalil. Quando Kalil escutou todo material disse que não tinha mais nada a acrescentar porque tudo já estava soando bem. A masterização foi feita por Fernando Sanches no estúdio El Rocha gerando a master final do disco que é encaminhada para a prensagem industrial $^{42}$. Uma vez prensado o disco, a canção termina seu ciclo de produção. Comparando a canção produzida com a canção bruta podemos formar uma tabela de transformações (Tabela 1).

A Ficha técnica da canção no disco:

Tatá: voz

Junior Boca: Guitarras e Coro final

Dustan Gallas: Baixo, Farfisa, Fast 4, Mellotron, Cravo e Coro final

Bruno Buarque: Bateria, Percussão e Coro final

Mixagem: Dustan Gallas

Masterização: Fernando Sanches

A canção produzida que nos chega pelo disco finalizado fecha uma etapa do ciclo criativo desses músicos lançando-os na etapa dos shows. O lançamento do disco cria um ciclo temporal de atividades profissionais para esses artistas que pode ser resumidamente dividido em três etapas principais: gravação - lançamento - turnê de shows. A cada novo disco o ciclo se repete. Durante a turnê, normalmente já começam a pensar no próximo disco que dará início a um novo ciclo. Tatá Aeroplano, por exemplo, já tem a ideia clara na sua cabeça de como será seu próximo disco, antes mesmo de terminar a turnê do disco atual. Já tem aprovado um projeto do ProAC, compôs algumas novas canções, já sabe quem será a banda

\footnotetext{
${ }^{42}$ A etapa do ciclo produtivo da canção que passa por uma lógica predominantemente industrial é a prensagem. É a única etapa que os músicos ainda não dominam e nem demonstram interesse em dominar. Eles preferem contratar uma empresa especializada e normalmente prensam tiragens pequenas de 1000 a 2000 cópias. Porém, vale notar que mesmo essa etapa industrial encontra atualmente alternativas diversas, um pouco mais próximas do que seria uma produção artesanal. Kiko Dinucci costuma realizar prensagens pequenas de alguns discos em copiadoras de CDs menores. Peri Pane é um compositor paulistano que fabrica uma a uma as capas de seu disco, "Canções Velhas Para Embrulhar Peixes". O industrial e o artesanal estão ambos presentes nesses processos observados, um não exclui o outro.
} 
da gravação etc. O lançamento de discos demarca um ciclo temporal da vida desse grupo de artistas. Seeger (2004) demonstra como entre os Suyá, existe uma criação do tempo socialmente estabelecida através das cerimônias e da música.

"O tempo como uma experiência social relevante é criado por sociedades e indivíduos agindo dentro dele. Embora os Suyá possam usar o sol, estrelas, lua e constelações para calcular o tempo, seus marcadores sociais importantes são impostos pelas canções." (SEEGER, 2004: 70).

Nas sociedades ocidentais o tempo é calculado em horas, dias, meses, anos etc. Porém, nesse grupo de artistas, a percepção da passagem do tempo é fortemente influenciada pelo ciclo útil do disco ${ }^{43}$. Os artistas organizam suas vidas e carreiras em função desse ciclo que pode durar entre um a cinco anos. Nos casos específicos de Tatá Aeroplano, Kiko Dinucci e Rodrigo Campos eles têm lançado discos a cada dois anos no máximo. Juliano Polimeno, que foi dono do selo de música PHONOBASE responsável pelo lançamento dos dois últimos discos do Cérebro Eletrônico, disse o seguinte:

"Tem o período de dois anos entre um disco e outro de um artista, dois anos parece um período normal para que um artista componha obras novas e consiga ter um conjunto de canções que lhe pareça interessante juntar, nominar e lançar como um conjunto..." (Entrevista com Juliano Polimeno, dia 12/05/2011).

No dia 16 de Fevereiro de 2012, o Cérebro Eletrônico realizou um show comemorativo de 10 anos da banda. Tatá lembrava em qual disco estava cada canção que a banda tocava. Os três discos lançados pelo Cérebro Eletrônico construíram a história da banda, a comemoração dos 10 anos era também uma celebração dos discos lançados durante o período. Todo show girou em torno desses discos, o repertório, os convidados especiais (André Abujamra, por exemplo, que foi convidado por ter participado do $2^{\circ}$ disco, Pareço Moderno), os arranjos das músicas. Enfim, cada disco produzido coloca o artista num ciclo temporal de atividades que se inicia com a gravação e termina no dia do último show da turnê. É uma relação com o tempo que lembra a dos grupos que vivem do cultivo da terra, a gravação seria equivalente ao momento de plantar e a turnê seria o equivalente da colheita. Depois de colher os frutos, deve-se plantar

\footnotetext{
${ }^{43}$ Para lembrar um trabalho clássico sobre o tempo como construção social vale lembrar EvansPritchard (1978). Um outro trabalho mais recente que aborda como as atividades musicais locais demarcam ciclos temporais é Finnegam (2008).
} 
novamente. A canção produzida representa o fim do plantio; com ela em mãos o artista inicia sua colheita, seja ela representada pela venda de discos ou pelos shows ao vivo. 


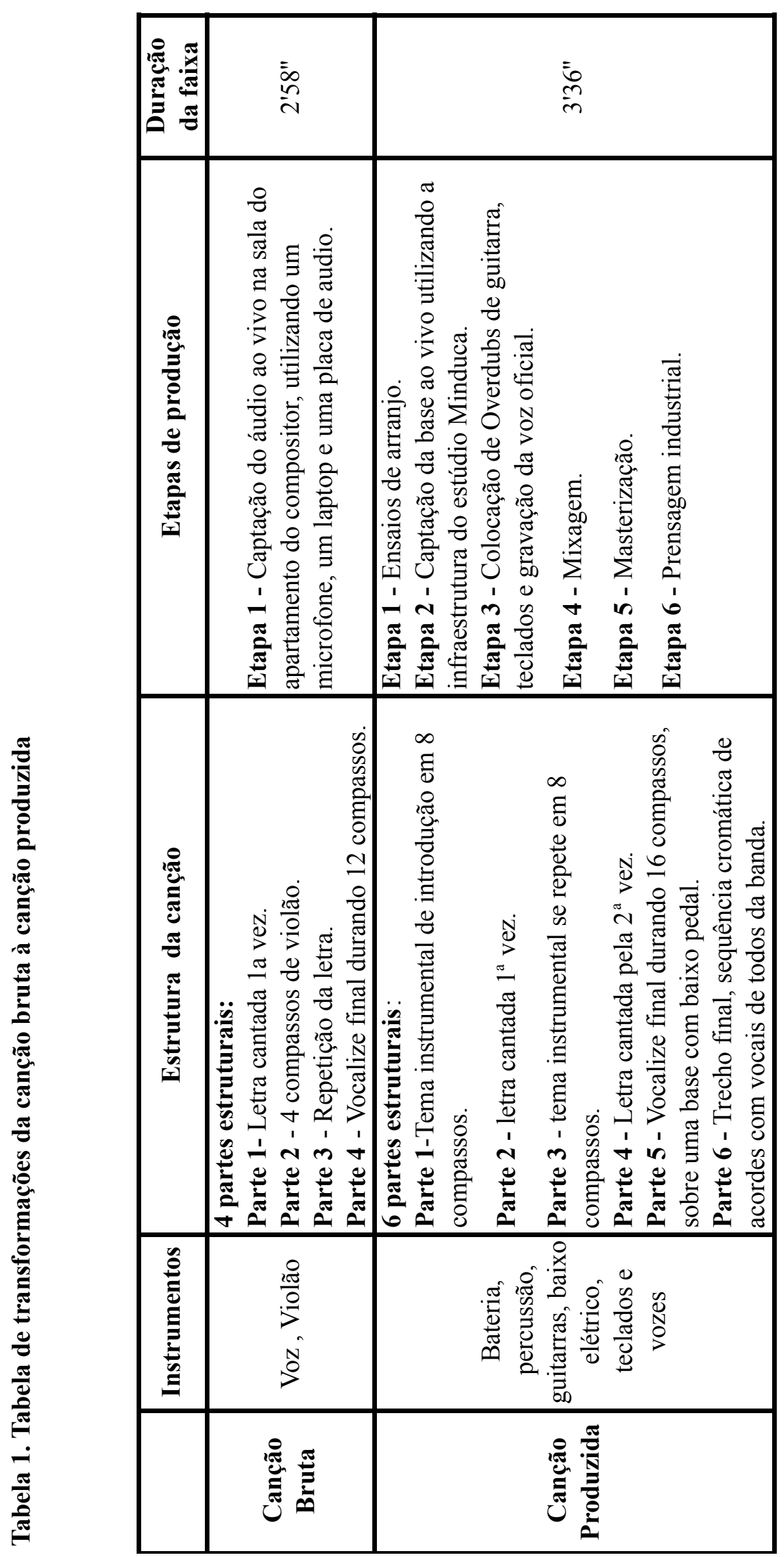




\subsection{Curto-circuito entre arte e técnica}

A partir de uma perspectiva etnográfica busquei descrever fazeres musicais contemporâneos onde a produção de discos autorais é central, ou seja, realizei uma etnografia musical dos discos em construção. Esses discos em construção podem ser entendidos também como os próprios artistas em construção. Como diria Gabriel Tarde "toda coisa é uma sociedade... todo fenômeno é um fato social" (TARDE, 2006: 81). O disco é uma sociedade; é um objeto artístico que encerra uma série de associações, é um artefato constituído por, e que constitui diversas relações sociais. Social aqui no sentido de Tarde, entendido como associação, desde a associação de músicos entre si, quanto a associação de músicos com instrumentos e computadores. Descrever as relações sociais por trás da música, produzida por um grupo de compositores em São Paulo, passa necessariamente pelas relações sociais envolvidas na produção de seus discos. O disco, aparentemente obsoleto por ter perdido valor enquanto mercadoria, emerge como uma mônada sonora que revela as associações humanas e nãohumanas constituintes de fazeres musicais contemporâneos. Sua observação revelou características importantes sobre as maneiras pelas quais um grupo sonoro urbano faz música e sobre como essa música faz o grupo. Dentre as principais características observadas destacamos as seguintes:

- Dinâmicas coletivas de arranjo e um autoral ampliado: Cada canção, que um ou mais compositores traz para uma gravação, passa e receber camadas melódicas, rítmicas e harmônicas de todos os músicos envolvidos no processo. Todos possuem liberdade para sugerir ideias e opinar na hora de produzir a canção tendo como pano de fundo os limites técnicos de cada situação. O domínio das tecnologias pelos músicos - e ser também dominado pelos encantamentos dessas novas tecnologias de produção musical - ampliam a autoria das canções que se transformam tanto dentro dos estúdios que se tornam outras obras; obras mais coletivas e cuja criação é agora mais compartilhada.

- Multiplicidade de competências (musicais, técnicas e artísticas): Músicos, intérpretes, arranjadores, compositores, técnicos de som, produtores musicais são categorias que emergem nesse tipo de produção mais autoral. Existe um sentimento comum de que a gravação é de todos, mesmo quando se trata de um disco solo. Existem os profissionais especialistas, mas predominam os profissionais que englobam diversas competências no seu fazer musical. 
- Músicos se colocando como audiência e como artistas: Isto está ligado à noção de que a visão do instrumentista virtuose é limitada - a visão dos leigos e dos artistas é mais ampla no que diz respeito a canções. Nesse grupo sonoro, o virtuosismo do instrumentista como aquele que é grande solista ou é capaz de tocar com velocidade não é valorizado; é valorizado o instrumentista que se comporta como o artista, pensando a canção de forma mais ampla, colocando a canção em primeiro plano e suas competências instrumentais em segundo plano.

- O que é produção musical: Produção musical aqui é entendida como essa capacidade de unir arte e técnica. Capacidade compartilhada por muitas pessoas nesse grupo. Todo artista se comporta, em alguma medida, como produtor musical em relação à sua obra. No caso de canções, a produção tem a ver com a melhor tradução possível do que o compositor quer dizer com os meios técnicos adequados. Isso passa pela escolha do melhor estúdio, escolha dos músicos e dos instrumentos, escolha da pessoa que fará a mixagem e a masterização.

- Espaço físico dos estúdios : O espaço físico dos estúdios é bastante variável em relação a tamanho. No geral, existe uma valorização dos estúdios cujo ambiente faz o artista se sentir em casa. O estúdio é um híbrido de casa e ambiente de trabalho. É um ambiente de trabalho que não deve parecer um ambiente de trabalho. Deve oferecer estrutura técnica adequada, mas deve ser minimamente confortável para os envolvidos numa gravação conseguirem passar horas a fio criando e tocando. O estúdio emerge como um espaço intermediário entre o formal e o informal, entre o público e o privado, entre o trabalho e o lazer. Um espaço onde os artistas querem se sentir a vontade. Ao mesmo tempo pensamos estúdios como recintos, como ambientes que criam um dentro e um fora, um dentro onde a natureza (sonora nesse caso) é manipulada e controlada.

- Etapas de produção de uma canção : Pudemos observar as principais etapas da produção de "Perigas Correr" que resumidamente podem ser organizadas em Composição (canção bruta) - arranjos - gravação - mixagem - masterização - canção produzida.

- A gravação do disco como o momento de "gravação de artistas" : O disco grava o artista porque transforma a atitude criativa de instrumentistas, compositores e intérpretes. Estes passam a pensar o mundo e os sons no momento de gravar, este é o salto de um indivíduo para categoria de artista. Grava o artista também porque torna pública sua obra que passará a circular fora de sua casa, fora dos estúdios; os discos caem no mundo. 
Todas essas características reunidas compõem um quadro interpretado aqui como um curto circuito entre arte e técnica. A grande novidade presente neste grupo sonoro, e talvez em toda uma geração de músicos, é que nesse início do século XXI os artistas dominam as tecnologias criativas do setor fonográfico que antes eram monopólio de grandes corporações industriais. Isso transforma profundamente o modo como se pensa e se faz música. Transforma também o disco enquanto artefato artístico. Podemos colocar o disco no meio do caminho entre a arte e a técnica. Ele é o híbrido que conecta esses dois adjetivos do fazer musical a partir do momento em que os artistas têm acesso aos recursos tecnológicos. É um dos mediadores fundamentais, no sentido latouriano do termo, no mundo da música contemporânea. Esta etnografia busca reconfigurar o lugar do disco que tem sido subestimado pelos estudiosos que o analisam como produto a ser vendido no mercado fonográfico. Autores como Herschmann (2010; 2011), Perpétuo e Silveira (2009) falam na perda da centralidade do disco, falam no aumento da importância dos shows ao vivo, no aumento do mercado digital de música. Concordo em parte com eles, o disco perdeu centralidade enquanto mercadoria, mas ganhou uma centralidade sem precedentes enquanto mediador do fazer musical contemporâneo. Creio que uma grande contribuição deste capítulo é trazer esse olhar para a discussão a respeito do lugar social dos discos.

O discurso nativo dos artistas e músicos indica, entre outras coisas, que quando pensam em criar suas próprias músicas ainda pensam em discos. A hipótese que se configura aqui é que isso ocorre por conta deste curto-circuito entre arte e técnica. A região em curto revela uma proliferação de mediadores - os próprios discos, os estúdios, os computadores, as interfaces amigáveis de softwares, as redes sociais na internet, as leis de incentivo, mas também os artistas que não são mais apenas artistas, são microempresários fonográficos, produtores musicais, arranjadores, instrumentistas. Humanos e não-humanos envolvidos nesse fazer musical conectam arte e técnica que no auge da grande indústria fonográfica, pelo menos oficialmente, estavam separados de forma mais clara no que diz respeito à produção de $\operatorname{discos}{ }^{44}$.

\footnotetext{
${ }^{44}$ Importante deixar claro que não afirmo que nos grandes estúdios não podem ocorrer processos similares. Se pensarmos nos Beatles temos um exemplo claro de grandes estrelas da música que se envolveram em todos os aspectos de sua produção. Não se trata de uma divisão rígida de mundos. Podemos simplesmente afirmar que, oficialmente, os grandes estúdios operam com uma divisão mais clara entre arte e técnica que pode ou não ser verificada nas práticas cotidianas.
} 
Os discos de Tatá Aeroplano de um lado, e os discos de Rodrigo Campos e Kiko Dinucci de outro são bastante diferentes entre si em termos musicais, mas vimos que existem traços repetidos nos três (e talvez em vários outros discos produzidos no período em questão). Dentre os traços comuns, o curto-circuito que o domínio tecnológico pelos artistas gerou é o mais distintivo. Um curto-circuito elétrico acontece quando uma carga elétrica maior passa entre dois pontos com impedâncias diferentes. Isso ocorre quando a resistência elétrica dentro do circuito diminui por algum motivo. No caso da produção fonográfica, a resistência era o alto custo de um disco, tecnologias de difícil manuseio por profissionais não especializados e o monopólio dos meios de divulgação e circulação. As tecnologias digitais e a internet derrubaram essas duas barreiras causando esse curto-circuito no antigo esquema do universo fonográfico. Uma avalanche de artistas solos e bandas que sempre desejaram gravar suas obras se viu numa posição inédita com os meios e ferramentas técnicos à disposição. Isso está gerando uma revolução nos fazeres musicais e uma profunda reconfiguração do disco enquanto obra de arte. Os discos são objetos/sujeitos que influenciam profundamente os processos criativos musicais contemporâneos. Os discos são actantes, isto é, são agentes. Essa agência dos discos é o tema do nosso próximo capítulo. 


\title{
CAPÍTULO 2
}

\section{Os Discos em Ação}

Neste capítulo, procurarei demonstrar como discos, artistas e público são mutuamente generativos entre si. Veremos como estes termos, ora agentes ora pacientes nas cadeias de relações em que estão imersos, se criam ou se produzem mutuamente, cada um fornecendo contornos de realidade um ao outro ${ }^{45}$. Essa demonstração passa pela análise do lugar dos discos no fazer musical de compositores em São Paulo a partir do conceito de agência. Isso implica reconhecer que os discos e as músicas que eles tornam públicas agem, ou seja, afetam de alguma forma as relações das pessoas envolvidas em sua produção. Utilizo aqui o conceito de agente formulado por Gell (1998).

\begin{abstract}
"Agência é atribuída àquelas pessoas (e coisas, veja adiante) que são vistas como iniciando sequências causais de um tipo particular, ou seja, eventos causados por atos da mente ou vontade ou intenção, ao invés de mera concatenação de eventos físicos. Um agente é aquele que "causa o acontecimento de eventos" em sua cercania. Como resultado deste exercício de agência, certos eventos acontecem (não necessariamente os eventos específicos que foram 'planejados' pelo agente). Considerando que cadeias físicas/materiais de causa-efeito consistem em 'acontecimentos' que podem ser explicados por leis físicas que governam o universo como um todo, agentes iniciam 'ações' que são 'causadas' por eles mesmos, por suas intenções, não pelas leis físicas do cosmos. Um agente é a fonte, a origem, de eventos causais, independentemente do estado do universo físico." (GELL, 1998: 16).
\end{abstract}

Já mencionamos que em São Paulo, grande parte dos artistas ligados à música está produzindo suas próprias composições e lançando discos de forma autônoma. O barateamento das tecnologias de produção musical tornou o músico capaz de gravar em casa, nos chamados home studios. Paralelamente, a internet permite que essa produção musical (muitas vezes caseira) circule rapidamente atingindo um número cada vez maior de pessoas. Isso não significa, automaticamente, que todos terão sucesso financeiro com suas composições. Com

\footnotetext{
${ }^{45}$ Quero agradecer e dar crédito aqui às ideias formuladas com clareza pelo professor Stélio Marras ao ler a primeira versão deste capítulo elaborada para o exame de qualificação. É dele o brilhante insight de que o material etnográfico que eu apresentara na ocasião permitia considerar como compositores, discos e público estão sempre envolvidos em "relações mutuamente generativas". (MARRAS, comunicação pessoal). Buscamos ao longo do texto explorar ao máximo essa perspectiva de slowsociolgy na qual a realidade nunca está pronta de antemão.
} 
tantas pessoas produzindo música, podemos dizer que vivemos uma fase de democratização dos discos. Porém, não é tarefa fácil se destacar com tantas pessoas gravando e compondo. Nesse oceano contemporâneo de gravações musicais, a originalidade emerge como uma meta estética, um valor, um conceito perseguido pela maioria dos compositores. Essa originalidade ganha expressão nos artefatos musicais analisados neste capítulo, os discos. Como os discos agem? Como os músicos se ligam a esses objetos? Qual a natureza dessa ligação? Em que medida os discos podem ser pensados como agentes nas relações onde se inserem? Estas questões podem trazer contribuições à antropologia contemporânea interessada em pensar a relação entre pessoas e coisas. Questões que serão exploradas a partir da etnografia do fazer musical de Rodrigo Campos, Tatá Aeroplano e Kiko Dinucci.

\subsection{O fazer musical de novos compositores}

Já coloquei anteriormente que realizar uma análise antropológica de qualquer manifestação musical implica transcender seus aspectos meramente musicológicos - melodia, harmonia, ritmo, formas de notação e de instrumentação, entre outras coisas - buscando um entendimento mais geral, isto é, um entendimento da música enquanto sistema cultural ${ }^{46}$, enquanto relação social, e enquanto parte essencial da vida das pessoas envolvidas na sua produção e na sua apreciação. Talvez essa ideia aparentemente simples que norteia a maioria dos antropólogos que lidam com música possa ser ampliada para pensarmos as relações entre antropologia e arte. O próprio Geertz (1983), lembra que a arte pode ser vista como expressão de um sentimento do artista pela vida. Esse sentimento pela vida se forma na conjunção de vários domínios interdependentes: religião, política, parentesco, tecnologia, comércio, economia, moralidade. Geertz argumenta que a bagagem intelectual com que um homem ordena sua experiência artística é variável e culturalmente relativa. Nosso olhar aqui tenta traçar as relações mutuamente generativas entre os agentes, considerando que os artistas produzem e são produzidos pelos discos e pelo público que tem acesso a esses discos. Lembremos que o artista é visto por Antônio Cândido ([1964] 2006) como um agente individual que comunica através da obra algo que tenha repercussão coletiva. Se o público

\footnotetext{
${ }^{46}$ A idéia de música como sistema cultural foi bem formulada por John Blacking. "Para entender tanto uma tradição musical quanto as contribuições que compositores individuais dão a ela, um sistema musical deve ser compreendido como um dos diferentes quadros de símbolos pelos quais as pessoas aprendem a produzir um sentido público de seus sentimentos e da vida social." (BLACKING, 2007: 204).
} 
não reconhecer a validade ou importância do comunicante individual, nada acontece, artistas e obras perdem seus contornos de realidade.

"Os elementos individuais adquirem significado social na medida em que as pessoas correspondem a necessidades coletivas; e estas, agindo, permitem por sua vez que os indivíduos possam exprimir-se, encontrando repercussão no grupo. As relações entre o artista e o grupo se pautam por esta circunstância e podem ser esquematizadas do seguinte modo: em primeiro lugar, há necessidade de um agente individual que tome a si a tarefa de criar ou apresentar a obra; em segundo lugar, ele é ou não reconhecido como criador ou intérprete pela sociedade, e o destino da obra está ligado a esta circunstância; em terceiro lugar, ele utiliza a obra, assim marcada pela sociedade, como veículo das suas aspirações individuais mais profundas." (CÂNDIDO, [1964] 2006: $35)$.

Se um músico grava um disco que não repercute coletivamente ele dificilmente será reconhecido como um artista, no máximo será tido como um artista menor. A música tem que reverberar junto ao público ouvinte para atuar na construção do artista no caso do mundo urbano ocidental. Em sociedades indígenas sabemos que a música opera de outras formas sendo que na maioria delas não existe uma separação clara entre artista-obra-público. $\mathrm{Na}$ perspectiva de Seeger, por exemplo, música não é somente som; “é todo o processo de conceitualização, realização, e valorização da música (SEEGER, 2004:65).” Em sua etnografia musical entre os Suyá, ele mostra como o ato de cantar reforça laços sociais, estabelece a passagem do tempo, demarca o território e expressa o status do indivíduo na comunidade. Os diversos estilos vocais Suyá criam, junto com todas outras esferas da vida, o que poderíamos chamar de cultura Suyá. Seeger argumenta que a música não é apenas parte da cultura, ela cria cultura, ela é cultura. Os Suyá cantam menos porque a música é bela ou prazerosa (não que ela não o seja), mas cantam para recriar sua sociedade, mantendo e reforçando os laços sociais como acontece, por exemplo, entre irmãos e irmãs na Mouse Ceremony ${ }^{47}$. Aqui não cabem juízos estéticos musicais a respeito da música Suyá, cabe entender como o canto cerimonial cria "um contexto social que influencia outros contextos." (SEEGER, Ibidem: 83).

Porém, apesar de todas as diferenças de perspectiva, mesmo para pensar um contexto urbano onde o músico pode se constituir como um artista-especialista, Seeger é uma referência

\footnotetext{
${ }^{47}$ Ritual de iniciação dos meninos Suyá que Seeger descreve com detalhes no livro "Why Suyá Sing?" Este ritual se inicia quando Hwinkradi pede para sua irmã que o deixe cantar seu shout song para o "recebedor de seu nome", seu sobrinho.
} 
fundamental. Ele propõe que uma boa etnografia da música deve abordá-la enquanto processo, ou seja, deve dar conta de descrever seu contexto social. O contexto poderia começar a ser descrito, segundo sua metodologia, ao levantarmos uma série de perguntas: $\mathrm{O}$ que se toca? Quem toca? Como se toca? Onde se toca? Quando se toca? Para quem se toca? E por que se toca música? Essas perguntas básicas, além de possibilitarem uma contextualização inicial do fenômeno, permitem ao pesquisador construir um estranhamento mínimo, necessário para qualquer etnografia. Ao analisar um grupo fazendo música nada deve ser considerado óbvio de antemão, por isso, a importância dessas perguntas aparentemente simples.

O trabalho apresentado aqui é uma etnografia de um tipo particular de música popular, a canção popular autoral produzida por novos compositores na cidade de São Paulo, o que torna o estranhamento antropológico algo que precisa ser, em parte, construído no decorrer da análise. Não estou analisando uma música distante de um grupo indígena isolado, estou analisando a música produzida em contexto urbano, um contexto onde sou 'nativo'. Sou nativo porque - além de viver na mesma sociedade, compartilhar valores, comportamentos, visões de mundo, língua materna - compartilho uma série de fazeres musicais com esses compositores. Como lançar um olhar distante a uma realidade tão próxima? Um fato que me causou certo estranhamento, ao me debruçar sobre esse universo musical urbano com o qual pensava estar totalmente familiarizado, foi a vivacidade da produção fonográfica num momento em que artistas, mídias, intelectuais e plateias testemunham a queda nas vendas de discos.

O fazer musical desses compositores está intimamente relacionado à produção de discos; um compositor sem um disco é uma espécie de compositor 'fantasma', invisível e inaudível. Hoje em dia, quem faz música popular de cunho autoral, ao menos em São Paulo, costuma gravar discos. Num contexto onde as novas tecnologias de gravação de áudio baratearam muito a produção musical, gravar seu próprio trabalho se tornou um tipo de pré-requisito para alguém desenvolver uma carreira artística musical. As perguntas de Seeger podem nos trazer uma noção inicial da importância da gravação de discos para se compreender esse tipo de fazer musical. Para exemplificar esse percurso etnográfico em contexto urbano, proponho que imaginemos juntos a seguinte situação: um jovem compositor deseja tocar suas canções; ele precisa de um espaço com as condições técnicas mínimas onde sua banda possa se apresentar. 
Uma unidade do $\mathrm{SESC}^{48}$, Serviço Social do Comércio, (um dos principais espaços para se ouvir música em São Paulo) seria um dos locais ideais para nosso proto-artista hipotético. Sobre a importância do SESC para os artistas em São Paulo o duo Moviola, formado por Kiko Dinucci e Douglas Germano, fez uma música emblemática e esclarecedora. "O Retrato do Artista Quando Pede" cuja letra diz:

"Pra sobreviver de arte em São Paulo, tenta o Sesc, tenta o Sesc. Mas se o programador não for com a tua cara esquece, esquece!"

Quase todas as perguntas formuladas por Seeger, quando aplicadas a um artista no contexto imaginado aqui - na cidade de São Paulo, num espaço de shows reconhecido como é o caso dos diversos SESCs - podem ser respondidas a partir do disco. O que está sendo tocado? Quase sempre o repertório de um disco. Quem está tocando? Quem já lançou o disco em questão. Como está tocando? Normalmente num palco bem equipado que responda às necessidades técnicas que a instrumentação presente no disco exige. Onde está tocando? No SESC, um espaço reconhecido socialmente pela qualidade de sua programação e que normalmente seleciona aqueles que disputam um lugar nessa programação através de seus discos. Quando? No caso dos SESCs, existe uma programação semanal fixa com várias atrações musicais. No SESC Pompéia, por exemplo, existe o projeto "Prata da Casa" que acontece todas as terças-feiras as 21 horas onde artistas que estão lançando seu primeiro disco se apresentam. Para quem? Para o público que frequenta o SESC ou que admira o artista que se apresentará naquela noite. Por que? No caso dos artistas que costumam se apresentar no SESC um dos motivos é a necessidade profissional, eles tocam porque recebem um cachê e dependem disso para continuarem atuando na música, já que sua renda vem predominantemente de shows ao vivo.

Esse exemplo hipotético poderia ser encarnado pelo show que o compositor Rodrigo Campos realizou no SESC Vila Mariana no dia 31 de maio de 2012. Nessa apresentação, Rodrigo Campos lançou seu $2^{\circ}$ disco, Bahia Fantástica, o repertório tocado foi formado com as

\footnotetext{
${ }^{48}$ Para nossos propósitos interessa informar que o SESC é formado por uma ampla rede de prédios e instalações, financiadas pelo Serviço Social do Comércio, cujo objetivo é promover as mais diversas ações sociais (culturais, educativas, esportivas e artísticas) junto aos associados e à população em geral que costuma frequentar seus espaços. O SESC é reconhecido pelos artistas como um dos poucos locais com infra-estrutura técnica adequada para realização de shows musicais. É uma piada comum entre músicos dizer que o SESC é o ministério da cultura em São Paulo.
} 
músicas do disco, os músicos que tocaram foram os mesmos que participaram do disco, os arranjos e instrumentação buscaram reproduzir o que fora gravado no disco, os convidados especiais foram os mesmos que participaram como convidados no disco, ou seja, todo evento girou em torno do disco. Esse exercício de imaginar um show no SESC é apenas uma provocação inicial para começarmos a questionar como se faz um tipo de música autoral em São Paulo, e como vivem as pessoas envolvidas com esse fazer musical autoral. Para Tiago de Oliveira Pinto (2001), “o fazer musical é um comportamento aprendido, através do qual sons são organizados, possibilitando uma forma simbólica de comunicação na interrelação entre indivíduo e grupo (PINTO, 2001: 224)." O fazer musical de compositores urbanos preocupados em criar uma música original está relacionado à importância da produção fonográfica, ou seja, da gravação de discos. Fazem parte de uma geração que aprendeu a compor gravando em casa, eles organizam o som com o auxílio de softwares de gravação, eles criam tendo como um dos objetivos principais o lançamento de discos. Para se compreender melhor o lugar e a importância da gravação de discos nesse fazer musical é necessário esboçarmos uma nova configuração desse objeto que transcenda seus aspectos mercadológicos que são normalmente o foco das análises sociológicas e econômicas que vislumbram sua perda de centralidade na indústria da música. A perspectiva antropológica que desenvolvemos busca uma superação da visão "purificadora" do objeto disco, isto é, a visão que coloca o disco numa redoma purificada em que toda uma rede de agentes é excluída - novas tecnologias, internet, público, jornalistas, prêmios, contratantes de shows e os próprios artistas. $\mathrm{O}$ disco ainda é central para artistas se constituírem enquanto tais, ainda é central para locais de show como o SESC, ainda é central para jornalistas especializados conhecerem a obra de um compositor, ainda é central para alimentar as pautas jornalísticas do mundo musical que ajudam a construir uma imagem pública de jovens compositores.

\subsection{Discos reconfigurados}

Como já afirmei no início desta dissertação, vivemos uma fase de intensa produção fonográfica em São Paulo, ao longo destes últimos anos ${ }^{49}$. Jovens artistas, compositores,

\footnotetext{
${ }^{49}$ Entre 2010-2011, somente falando dos que vivem em São Paulo, tivemos o lançamento dos discos dos seguintes artistas: Céu, Tulipa Ruiz, Rodrigo Campos, Rômulo Fróes, Lurdez da Luz, Passo Torto, $3 \mathrm{Na}$ Massa, Cris Aflalo, Fábio Góes, Metá-Metá, Mariana Aydar, Criolo, Bixiga 70, Cérebro Eletrônico, Karina Buhr, Bluebell, Rebobina, Pélico, Danilo Moraes, Gui Amabis, Guizado, Peixoto e Maxado, Seychelles, Axial, Andréia Dias, Mauro Motoki, Marginals, Anelis Assumpção, Lu Horta, Gafieira São Paulo etc. Enfim, a lista é imensa e a tendência é que não pare de aumentar.
} 
intérpretes, bandas (de canção ou instrumentais) estão gravando discos avidamente, nos mais variados tipos de estúdios, e os lançando nas mais variadas formas. Disco aqui deve ser pensado em suas múltiplas configurações contemporâneas: de um lado, os suportes físicos (disco de vinil e Compact Discs) e de outro, os formatos digitais (downloads gratuitos ou pagos feitos em Wave e MP3 de álbuns e/ou singles). Um destes novos compositores, chamado Mauro Motoki, lançou seu trabalho solo, “Bom Retiro”, em 2011, num suporte até então incomum no Mercado brasileiro, o pendrive ${ }^{50}$. O ouvinte compra um pendrive onde está escrito "Mauro Motoki - Bom Retiro", pluga no computador ou em algum tocador que tenha entrada USB, e pode ouvir seu disco. Como bônus, o ouvinte pode ficar com um pendrive novo para ser utilizado como quiser. Ele optou por não prensar CDs, escolheu esse suporte pendrive e ainda prensou alguns poucos discos de vinil. Esse exemplo particular de Mauro Motoki reforça o fato de que os artistas estão gravando suas músicas e lançando em suportes variados, utilizando novas e velhas tecnologias ao mesmo tempo, e de alguma forma mantendo um padrão de tempo e tamanho de repertório (entre 10 a 15 músicas reunidas totalizando de 45 minutos a uma hora de música em média por disco) que nos acompanha desde o surgimento dos primeiros discos de vinil ${ }^{51}$. A palavra disco, tal qual utilizada por esses artistas, abarca esses múltiplos suportes e representa mais do que um objeto físico pode ser entendida aqui como uma forma específica de criação artística que caracteriza um fazer musical contemporâneo.

O disco é um suporte para músicas. Esse suporte, normalmente, vem embalado em capas que apresentam fotos dos artistas, desenhos, pinturas, gravuras ou outros tipos de imagens artísticas. A primeira coisa que atrai nossa atenção num disco é a capa. Antes de ouvir um disco o ouvinte se depara com sua embalagem. Trata-se quase de uma experiência tátil admirar uma capa de disco, já que os raios de luz das imagens tocam nossas retinas, antes de

\footnotetext{
50 “Mauro Motoki possui um vasto currículo no mundo dos acordes, riffs e beats. São 15 anos como músico profissional, dez deles com o Ludov - banda de pop rock que o país inteiro conhece e que roda o Brasil com shows lotados. Ele ainda atua como produtor e músico da dupla de ska Peixoto \& Maxado e de Miranda Kassin. E agora lança seu primeiro trabalho solo,"Bom Retiro".

O título é uma homenagem ao bairro paulistano que abriga seu estúdio, em parceria com Fabio Pinczowski, o 12 Dólares, onde o disco foi concebido. "Bom Retiro" está sendo lançado em dois formatos: pendrive e vinil de 12 polegadas." (Extraído do site: http://screamyell.com.br/blog/2011/12/04/mauro-motoki-do-ludov-estreia-solo-ouca/ em 13/04/2012 as 10:47 horas).

${ }^{51}$ Os vinis surgiram em 1948 substituindo os discos de goma laca de 78 RPM (rotações por minuto). O disco de vinil possibilitou um tempo maior de registro sonoro em cada lado.
} 
chegarem ao nosso cérebro ${ }^{52}$. Pegamos nas mãos e abrimos a capa para acessar o disco em si. No caso do LP em vinil, um disco tem em média $30 \mathrm{~cm}$ de diâmetro. No caso do $\mathrm{CD}$, o Compact Disc, um disco tem em média $11,8 \mathrm{~cm}$. As embalagens dos discos de vinil apresentam um padrão que varia pouco, são feitas numa espécie de cartolina, um papel mais grosso. O disco vem protegido por um plástico dentro dessas embalagens de papel duro. No caso dos CDs, as capas e contra-capas são feitas de papel e tradicionalmente ficam dentro de caixas de plástico transparente. Me lembro que os primeiros $\mathrm{CDs}$, tinham plástico transparente na capa e nas costas, onde ficaria a contra capa de um vinil, o plástico era preto. Me lembro também, que achei muito bonitos os primeiros CDs com as costas das caixas toda transparente. Cada detalhe, cada mudança nas capas e embalagens eram percebidos e discutidos pelos apreciadores de música, tanto quanto os sons. As capas e contracapas são acompanhadas por livretos e juntos compõem o chamado encarte do disco. Os encartes são fontes de informações artísticas e técnicas ${ }^{53}$. O encarte do disco Padê de Juçara Marçal e Kiko Dincci, para se ter um exemplo, traz várias gravuras feitas por Kiko Dinucci. Na folha da frente, uma gravura representando a cara de Juçara Marçal com o nome do disco. Na última folha, uma gravura representando a cara de Kiko Dinucci com o nome e a duração das 14 músicas. A décima música, "Velha Morena", é a mais curta com duração de 1;37 minutos. A sétima música, "Mar de Lágrimas", é a mais longa com 4:28. O padrão de 3 minutos em média por canção predomina no disco inteiro. O livreto de Padê tem oito páginas onde estão escritas todas as letras e ficha técnica de cada canção. A maioria das composições é de Kiko Dinucci. Juçara Marçal canta todas, Kiko Dinucci toca violão em quase todas e canta em algumas junto com Juçara Marçal. Na segunda página, um pequeno texto explica o significado do termo Padê.

"Em língua iorubana, a palavra Padê (Padé) significa encontrar. Na tradição afroreligiosa (predominantemente no candomblé) Padê costuma ser a cerimônia inicial dedicada ao Orixá Exu, em que lhe são oferecidas cantigas e feitas homenagens basicamente com farofa de dendê e quartinha de água, despejados da entrada do terreiro para a rua."

\footnotetext{
${ }^{52}$ Para uma discussão detalhada sobre a mundo visual como uma experiência tátil cf. Taussig (1993), em especial o segundo capítulo.

${ }^{53}$ Mesmo nos discos virtuais lançados através da internet ou no pendrive as capas estão presentes, seja através de links que direcionam o internauta, seja através de imagens anexadas ao arquivo que contém o material sonoro.
} 
Na última página do livreto, encontramos as datas e locais de gravação, os responsáveis técnicos (mixagem e masterização), fotógrafo e agradecimentos. Nesse disco não há informação sobre quem foi o produtor musical. Juçara Marçal e Kiko Dinucci aparecem como diretores musicais do trabalho. A última informação do livreto é de que o disco foi feito com o Prêmio Ney Mesquita de 2007, criado pela Cooperativa de Música. O repertório do disco não contradiz o título. As músicas, os nomes e as letras com várias palavras de origem africana deixam claro que existe uma matriz Africana. $O$ universo poético-musical é do candomblé. A letra da canção "Padê", que abre o disco, abre também os caminhos "pro mensageiro passar" ao som de atabaques, violão e baixo elétrico. As quatro primeiras faixas do disco apresentam exatamente a mesma instrumentação, atabaques na base rítmica, violão e baixo harmonizando e a voz cantando melodias com letras inspiradas pelo candomblé. A religião afro-brasileira é o conceito que permeia todo disco, tanto os aspectos poéticos e sonoros, quanto os aspectos visuais da capa.

No início de Julho de 2012, o disco solo de Tatá Aeroplano, que leva o nome do artista, chegou da fábrica de prensagem. Chegaram mil cópias em CD com um tipo de embalagem um pouco diferente da embalagem plástica de Padê. No caso de Tatá Aeroplano, a embalagem é um híbrido de cartolina com um suporte de plástico colado dentro onde se encaixa do CD. Esse tipo de capa é chamado digipak (ou digipack) feito normalmente para versões especiais de lançamentos em DVD ou CD. A capa é um foto de Tatá Aeroplano com um lindo entardecer ao fundo. Uma moldura preta envolve a foto e traz o nome do artista em laranja. A contracapa apresenta outra foto do artista, dessa vez sem moldura, e o nome das dez canções do disco, assim como no caso de Padê (só que dessa vez sem o tempo de duração). O livreto dentro do encarte tem 16 páginas, onde encontramos todas as letras e ficha técnica de cada faixa, intercalados com diversas fotos do artista. Na última página, uma foto de Tatá pulando de braços abertos como se o Aeroplano fosse decolar. As informações técnicas e agradecimentos aparecem na penúltima página. A primeira informação dessa página é: "Produzido por Dustan Gallas e Junior Boca - Canções arranjadas coletivamente e gravadas em Dezembro de 2011." O compositor interpreta todas as canções do disco sendo que quase todas elas tratam de relações amorosas, casos passionais, brigas, sexo e noitadas. A instrumentação básica de um disco de rock permeia a maioria das faixas. Bateria, guitarra, teclados e baixo elétrico resolvem os arranjos. Os timbres remetem de alguma forma aos anos 60 . 
Mesmo com todas as diferenças poéticas, estilísticas, sonoras e visuais que esses discos apresentam entre si, observamos a permanência de uma forma comum. Ambos mantêm um formato estrutural do século passado, o formato 'álbum" - um determinado número de faixas musicais que duram em média 3 minutos cada, totalizando um tempo de 45 minutos em média por disco. Esses artistas perpetuam o disco enquanto forma artística ${ }^{54}$. Seu processo criativo respeita essa forma básica, um conjunto de faixas separadas reunidas num repertório, embaladas por encartes que trazem nomes, letras e informações técnicas. O que causa um certo estranhamento é que a forma pela qual os consumidores escutam música está mudando. O consumo de álbuns e faixas de MP3 isoladas via internet aumentou, enquanto a venda de discos físicos caiu (MACHADO; NOLASCO, 2011), (HERSCHMAN, 2010; 2011). Por que a forma de criação musical permanece a mesma - pela via da produção no formato de disco tradicional - enquanto o a forma de consumo se transforma? Por que o disco se mantém com a mesma estrutura formal básica - tempo de duração, tamanho das músicas, instrumentações, capas e contracapas - com tantas transformações acontecendo? Por que ainda é importante lançar o suporte físico, mesmo com a proliferação dos discos virtuais? Buscaremos analisar a perspectiva dos artistas que mantêm vivo o disco enquanto formato (álbum com 10 a 15 faixas cuja duração média é de três minutos) e enquanto suporte físico (basicamente CDs e discos de vinil).

"Acho fundamental lançar o físico, ainda existem lojas que trabalham muito bem o físico, como a Livraria Cultura, Livraria da Vila, lojas tradicionais de São Paulo como Baratos \& Afins, Pop's Discos, Compact Blue! CDs e Vinis são vendidos pelo site e em shows também! Se você lança um disco e faz uma média de 30 shows de discos, é fundamental ter o álbum, porque de uma maneira ou de outra você acaba vendendo discos. O Vinil foi um acerto ter feito, vendi bem e também consegui ter uma boa margem de lucro em cada cópia de vinil vendida, mesmo assim vendi bem mais em conta para as lojas, pro Vinil não ser vendido por mais de 60 reais.” (Entrevista com Tatá Aeroplano, dia 24/05/2012).

"Lanço CD físico porque creio que uma mídia não substitui outra, por mim lançaria tudo em CD, vinil, EP, single, cassete e por aí vai. O vinil é o formato que mais gosto do som,

\footnotetext{
${ }^{54}$ Importante enfatizar aqui que essa geração de artistas tem acesso à tecnologias de produção musical novas, mas as utilizam perpetuando um formato. $\mathrm{O}$ curto-circuito entre arte e técnica mencionado no capítulo 1 ainda não transformou o formato dos discos, ou seja, tempo de duração, número de faixas, forma de nomear o trabalho etc.
} 
a parte gráfica também ganha destaque nesse formato." (Entrevista com Kiko Dinucci, dia 20/05/2012).

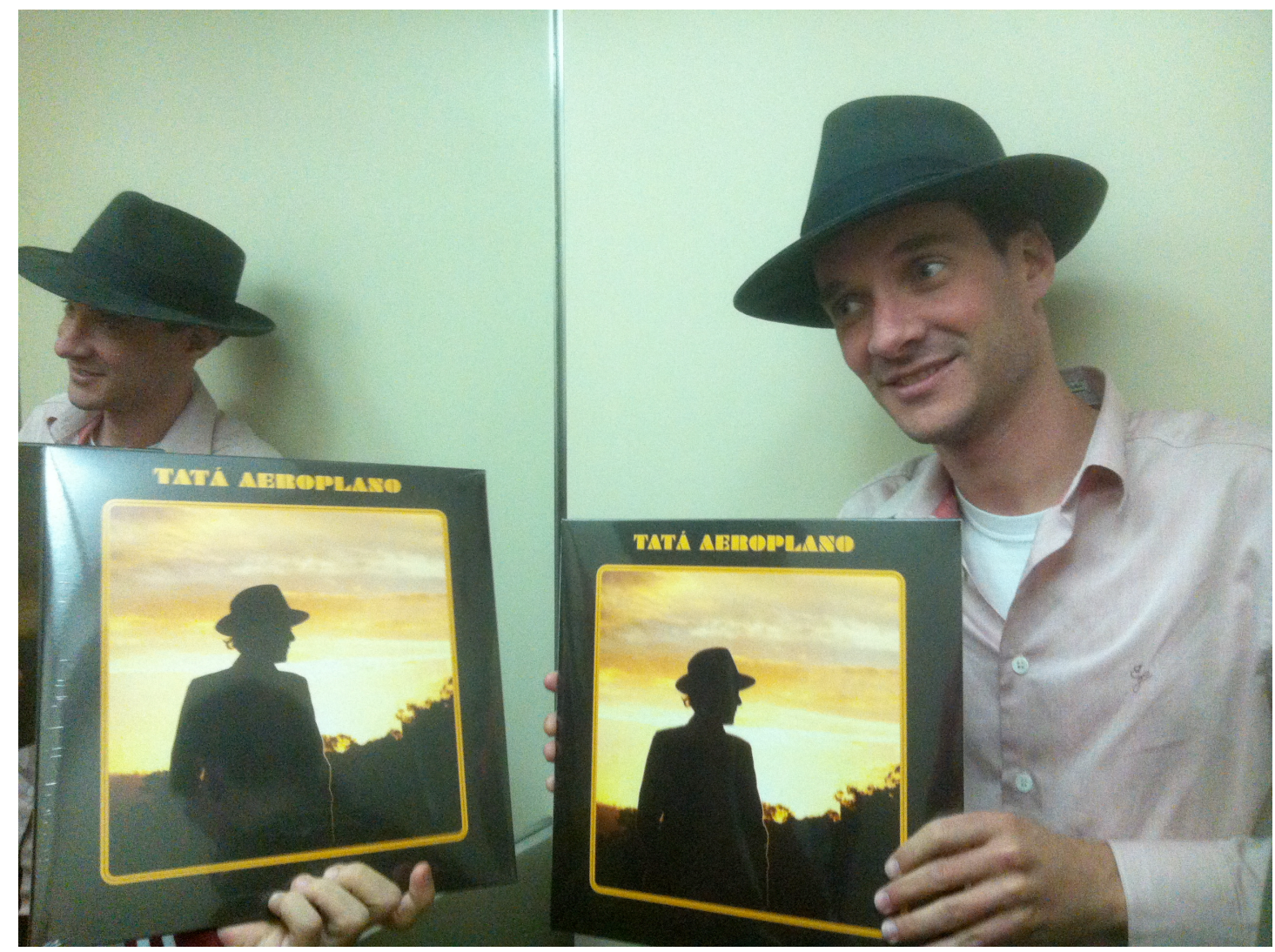

Tatá Aeroplano no dia em que recebeu seus discos de vinil da fábrica

Nesse início de século XXI, gravar um disco, tornando-se algo mais simples através de novas tecnologias de áudio, se tornou uma prática compartilhada por diversos músicos; é a forma encontrada por muitos compositores para criarem suas obras de arte musicais. Essas obras de arte musicais, basicamente, são formadas pela reunião de um conjunto de músicas que fazem sentido quando colocadas juntas, comunicam algo, dão expressão a um sentimento pelo mundo e, como disse Oliveira Pinto (2001) sobre o que caracteriza um fazer musical, possibilitam uma comunicação simbólica na inter-relação do indivíduo com o grupo. Além disso, ao reverberarem coletivamente constroem o artista enquanto tal a partir da tríade fundamental que Cândido ([1965] 2006) enfatiza - autor, obra e público. O disco físico emerge como um dos agentes causais que intercambia propriedades com músicos, jornalistas, ouvintes e contratantes de shows, que são outros agentes causais envolvidos na rede generativa dos artistas. Nas matérias de jornais, nos releases, nas entrevistas de sites, nos blogs e nas biografias online que tratam dessa produção musical encontramos diversas 
palavras como - "álbum”, "trabalho", "obra”, "arte” - para expressarem o conteúdo que cada um está produzindo. Porém, ao iniciar o trabalho de campo, nas entrevistas e conversas informais, a maioria das pessoas envolvidas utiliza a palavra "disco", mesmo quando o lançamento é feito somente online, sem a mídia física. Disco é o principal termo nativo para designar esse formato musical encontrado em diversos suportes.

Um aspecto importante a ser notado aqui é que todos os discos possuem um "nome." Na verdade, eles possuem um nome principal (o nome mais significativo que é o nome do artista), mas tornam público uma série de outros nomes (os nomes das músicas, o nome dos músicos, o nome do estúdio, o nome dos técnicos de mixagem e masterização, agradecimentos finais). Algumas vezes, um disco recebe um nome que não coincide nem com o nome do compositor, nem com o nome das músicas, como é o caso do disco Bahia Fantástica. Segundo Rodrigo Campos, o título desse disco remete a uma Bahia que não é o estado da Bahia real, mas sim uma Bahia imaginária criada a partir do seu contato com a Bahia real. Essa Bahia imaginária é habitada por personagens fantásticos que expressam reflexões metafísicas do artista sobre os limiares da vida e da morte. Nesse caso específico, o nome do disco expressa um conceito permeando todas as composições. Dessa perspectiva, os discos também podem ser interpretados como um sistema de nomes do universo musical. Esse sistema de nomes pode ser dividido em dois grupos: os nomes das músicas e do disco que são criações do artista, e os nomes dos profissionais envolvidos na produção que identificam as competências de cada um. Os primeiros nomes são aqueles que realmente vão delimitar a contribuição artística do compositor identificando e individualizando sua obra. $\mathrm{O}$ segundo grupo de nomes é importante para o currículo profissional de cada um que trabalhou na gravação de um disco, seja um músico instrumentista ou um engenheiro de som.

A ideia de que o disco pode ser entendido como um objeto que expressa um sistema de nomes é fortemente inspirada por discussões provenientes de nossa disciplina. Muitos autores já trataram da importância de se compreender os sistemas de nomeação nas sociedades humanas. Mauss (2003) começa seu clássico ensaio sobre a noção de pessoa abordando os nomes clânicos entre os índios Pueblo de Zuni descritos por Frank Hamilton Cushing. Cushing encontrou um número determinado de prenomes por clã, sendo que cada prenome expressa o papel exato que cada pessoa desempenha na figuração do clã. O prenome é componente fundamental na formação de uma consciência de si mesmo dentro do grupo. $\mathrm{O}$ nome estaria então relacionado a um senso de individualidade. "Direi apenas: é evidente, 
sobretudo para nós, que nunca houve ser humano que não tenha tido o senso, não apenas de seu corpo, mas também de sua individualidade espiritual e corporal ao mesmo tempo." (MAUSS, 2003: 371). Esse senso de individualidade é constitutivo da noção ocidental de pessoa que Mauss formula. Os discos representam a possibilidade dos artistas do mundo musical expressarem sua individualidade, sua originalidade e nomearem sua obra, aspectos essenciais da pessoa maussiana. $\mathrm{O}$ fato de um disco ter um nome faz dele também uma pessoa.

Se para Mauss, nunca houve ser humano que não tenha tido o senso de seu corpo e de sua individualidade, no campo da música não é tão evidente que todo músico tenha tido sempre um senso de sua musicalidade individual. Em diversas sociedades, a música é muito mais um fenômeno coletivo, ritualístico ${ }^{55}$ e cerimonial do que algo individualizado. Os discos podem ser vistos como a expressão máxima de uma individualidade artística no mundo musical ocidental; estão associados a pessoas específicas (seja essa pessoa uma banda, uma orquestra ou um único artista). Entretanto, eles não são meras expressões de uma individualidade pronta e acabada de artistas prontos e pré-existentes. Os discos são sujeitos actantes que constroem esses indivíduos-artistas, inclusive, são agentes causais fundamentais para que um músico se veja como indivíduo que se torna artista. Entretanto, ao mesmo tempo em que constroem e individualizam, os discos tornam o artista divisível na medida em que possibilitam que sua agência criativa se destaque do seu corpo individual. Quando um artista lança mil cópias de um disco físico, ou lança seu disco virtual na internet, ele está multiplicando a presença de sua pessoa musical. O disco é uma pessoa em si mesmo; ele duplica e presentifica a pessoa do artista; onde seu disco chegar, seu nome, sua arte, e uma parte de sua pessoalidade chegam. Ele individualiza num certo sentido, e coletiviza na medida em que torna público e multiplica uma presença. A frase de Midani (2008), citada anteriormente, de que "botou João Gilberto debaixo do braço" é um ótimo exemplo de como os discos também são pessoas.

\footnotetext{
${ }^{55}$ Para Benjamin (1980), um dos efeitos das técnicas de reprodução é subverter o caráter ritualístico dos objetos de arte reinserindo-os numa nova práxis que seria política. De fato, as tecnologias de reprodução sonora reconfiguraram a música enquanto arte, por exemplo, ao tornar possível a reprodução de uma sinfonia na sala de casa. Na medida em que essas tecnologias de reprodução se tornam mais utilizadas pelos próprios músicos elas reconfiguram também os discos. Ao meu ver, os processos descritos no primeiro capítulo e os casos que analisaremos nesse segundo capítulo estão ligados a uma valorização da produção autônoma de discos como algo carregado de aura, para utilizar um termo benjaminiano. A aura dos discos está ligada ao caráter único dos encontros que acontecem dentro dos estúdios e que são expressos nos discos. Cada disco nesse universo de músicos é uma associação única e singular de eventos. O disco reconfigurado não ilude os ouvintes, não aliena os músicos, ele é a expressão autêntica de um fazer musical contemporâneo onde as fronteiras entre técnica e arte se interpenetram.
} 
Em Gênero da Dádiva, por exemplo, Marilyn Strathern trabalha o tempo todo com uma oposição analítica entre Ocidente e Melanésia como dois sistemas de pensamento diferentes. No Ocidente, os objetos são pensados como coisas separadas das pessoas. Na Melanésia, seria exatamente o oposto; pessoas e coisas são inseparáveis. As relações de troca cerimonial entre povos melanésios revelam pessoas por trás das coisas, cada dádiva trocada revela quem são as pessoas envolvidas. Na economia mercantil, segundo a metáfora analítica de Strathern, é como se as coisas encobrissem as pessoas preservando o indivíduo anônimo que compõe as massas consumidoras urbanas. Latour diria que essa visão da mercadoria como alienada e alienadora é apenas sua versão moderna purificada, ou seja, sua versão oficial. No caso dos discos, talvez eles nunca tenham sido somente essa mercadoria purificada, eles sempre foram mais do que isso, nunca estiveram totalmente desencantados mesmo no auge da grande indústria fonográfica.

Entre esse grupo de artistas o disco não é visto somente como mercadoria ${ }^{56}$. Assumindo que etnografar é produzir um texto carregado de metáforas analíticas, pode-se argumentar que os discos produzidos por esses artistas autônomos da canção se equilibram entre uma lógica de troca de dádivas e uma lógica de trocas mercantis. Para Strathern, a troca de dádivas é uma lógica pela qual os melanésios descrevem o mundo. Dentro dessa lógica, cada dádiva trocada conecta pessoas, produz laços sociais e ativa identidades de gênero. Será que poderíamos pensar nos discos como obras de arte que oscilam entre essas duas lógicas que Strathern coloca? O que emerge nessa nova configuração é a construção e manutenção das relações mutuamente generativas entre disco-artista-público.

No dia 23 de Março de 2012, num debate sobre música independente promovido na FUNARTE, o compositor Kiko Dinucci afirmou: "O disco ainda é uma vitrine, mas você têm que fazer algo novo. O trabalho é o que mais divulga. Se o disco for alguma repetição do que já foi feito é difícil se sobressair, mesmo com a internet." Além do "disco" como "algo novo" temos que estar atentos para a rede de outros agentes causais que trocam propriedades com discos e artistas para darmos conta de compreender como esses entes ganham contornos de realidade. O próprio Kiko Dinucci é uma propriedade emergente dos discos que produziu, das

\footnotetext{
${ }^{56}$ Mesmo Tatá afirmando que vendeu bem, vale notar que ele não depende financeiramente das receitas obtidas com os discos. Vender bem aqui significa no máximo se capitalizar para o próximo disco.
} 
músicas que compôs. Reconfigurar o objeto disco começa por analisá-lo não como uma mera mercadoria, como uma coisa inanimada e passiva, mas entender sua importância nas relações sociais que envolvem os artistas, entender como ele desempenha um papel ativo na formação de uma pessoa artístico-musical (a autoconsciência do artista músico em relação a sua obra). Ao mesmo tempo em que se democratizou por se tornar mais fácil de gravar, um disco se tornou uma "vitrine" fundamental para um compositor. Os discos tornam pública sua criatividade, aquilo que o torna diferente e que pode fazer com que ele se sobressaia em relação aos demais, ou seja, expor ao mundo sua pessoa artístico-musical. A seguir veremos como a gravação de um disco agenciou transformações fundamentais na vida do compositor Rodrigo Campos.

\subsection{Rodrigo Campos - São Mateus Não é um Lugar Assim Tão Longe}

Dia 22 de Maio de 2009, fui à Livraria da Esquina, uma pequena casa de shows na Barra Funda, para assistir a uma das apresentações de lançamento do $1^{\circ}$ disco de Rodrigo Campos. Apesar do nome, Livraria da Esquina, não se trata de uma livraria tradicional e sim de um espaço para pequenos shows onde cabem cerca de 200 pessoas. Trata-se de um dos poucos espaços que se arriscam em receber compositores ainda desconhecidos, que ainda não tenham público formado. Rodrigo Campos estava realizando a primeira série de shows das músicas de seu disco, ele ainda era um compositor desconhecido na época. Até então, era mais conhecido como instrumentista, tocando cavaquinho com grupos e artistas de samba como Fabiana Cozza. O show foi ótimo, as músicas delicadas e intimistas falando da infância e juventude do compositor em São Mateus. Sai de lá satisfeito, mas sem o CD na mão, porque só tinha levado dinheiro para o ingresso.

Como já informado anteriormente, Rodrigo Campos, natural de Conchas e criado no bairro paulistano de São Mateus, lançou seu primeiro disco, São Mateus Não é um Lugar Assim Tão Longe, em 2009 com o apoio da Petrobrás, via Lei Rouanet. Esse trabalho de estreia foi muito bem recebido pela crítica especializada em música ${ }^{57}$. Segundo ele, foi um ponto muito

\footnotetext{
57 “São Mateus Não é Um Lugar Assim Tão Longe (2009), primeiro disco solo de Rodrigo Campos, foi selecionado no Programa Petrobras Cultural. Ganhou, também, o Troféu Cata-Vento, prêmio da Rádio Cultura, na categoria melhor disco de 2009, além de ser eleito pelos jornais O Estado de São Paulo, Folha de São Paulo, O Globo e Jornal ABC (Porto Alegre) um dos dez melhores discos de 2009." (Extraído da página do Facebook do compositor : http://www.facebook.com/pages/RodrigoCampos/147936145298226?sk=info dia 20/13/2012 `as 10:17 horas).
} 
importante da sua vida e que transformou toda sua carreira, tanto como instrumentista quanto como artista. Um objeto de plástico metalizado, guardado numa capa de papelão, com uma série de músicas inéditas agenciou transformações que nem o próprio compositor poderia imaginar. Essas transformações todas são operadas na medida em que o disco troca propriedades com outros agentes como a crítica especializada, as casas de shows, as rádios, o público.

"Esse disco também fez com que eu me reconciliasse com minha familia porque foi bem recebido pela crítica, saiu em todos os jornais, ganhou prêmio de melhor disco, e tem uma música dedicada à minha mãe, outra dedicada ao meu pai com o nome verdadeiro deles, então foi uma coisa que eles ficaram super emocionados... olha poxa no quê que virou... eles entenderam a diferença que é você ser um músico da categoria que eu queria ser, da espécie de músico que eu queria ser." (Entrevista com Rodrigo Campos, dia 20/05/2011).

Rodrigo Campos morou toda sua juventude no bairro de São Mateus, um bairro periférico conhecido pelo seu samba, mas também pela violência e descaso público característicos de diversos bairros periféricos da grande São Paulo. Seu pai, Isac sempre admirou o talento musical do filho, porém quando este decidiu largar a faculdade de direito para ganhar a vida como músico houve uma ruptura não só com o pai, mas com o bairro de São Mateus.

"E então eu cheguei a estudar dois anos (de direito) e aí um dia eu cheguei e falei pra ele (o pai Isac).... Eu quero ser músico! Porque até então era uma brincadeira, quando eu era menininho pequenininho ele gostava, levava mostrar pros amigos, tinha uma brincadeira que eu fazia assim.... tocava um pedaço do brasileirinho e punha o cavaquinho aqui nas costas... tosco pra caramba, mas ele gostava e mandava eu fazer pra todo mundo isso... "Toca o brasileirinho nas costas" aí eu lá no boteco tocava o brasileirinho nas costas. Enquanto era uma brincadeira ele curtia, quando começou a ficar sério o negócio começou a pesar, aí quando teve essa ruptura mesmo com ele foi quando eu abandonei a faculdade de direito e fui estudar música na Fundação das Artes de São Caetano do Sul.” (Entrevista com Rodrigo Campos, 20/05/2011).

Rodrigo ficou durante anos sem voltar ao bairro de São Mateus depois que veio para a região central tentar a vida como profissional da música. Tocou com diversos artistas, deu aulas, 
tocou em boteco e foi professor de música na Febem. Porém, somente com a gravação de seu primeiro disco pôde reconquistar a admiração paterna. Um músico que grava um disco e sai no jornal vira uma outra categoria de músico. Eu salientei em itálico o trecho da entrevista em que o próprio Rodrigo coloca o disco como sujeito da frase. Foi São Mateus Não é um Lugar Assim Tão Longe que fez com ele se reconciliasse com Isac. O disco trouxe aos ouvidos de Isac a homenagem do filho distante. No samba, Isac, Rodrigo Campos cantou e encantou seu pai como vemos a seguir na letra.

Isac de Campos é o cara das multidões.

Não sabe se a dor que tem é sua ou de outro alguém.

Não sabe se amanhã, não sabe se depois,

Não sabe quanto tempo vai durar!

Isac de Campos é um cara fenomenal,

Conhece de futebol e não é nenhum Mané.

Não é nenhum Pelé, não é nenhum João,

Não é nenhum Mané Garrincha não!

Isac de Campos tem a ginga de menestrel,

Trabalha no Santander, tocava trompete em dó,

Menino da canção, da comemoração,

Menino que quer se aposentar.

Isac de Campos vai 'as quartas na Universal,

Ou será que é na Cristã do Brasil?

Em alguma sei que ele vai, é!

É o homem da mulher, o homem da Cristã

O homem em busca do seu lar!

Steven Feld (1982), ao estudar os cantos e lamentos Kaluli em Sound and Sentiment, mostrou como as palavras quando cantadas ganham outra expressividade. A simples indagação "Pai aonde vai você?" poderia remeter a uma situação cotidiana do pai indo caçar e deixando o filho em casa. Porém, a mesma frase, quando cantada, deixa claro para um Kaluli que o pai em questão morreu ou abandonou o filho, gerando um sentimento de profunda tristeza. Essa letra do samba Isac, escrita numa folha de papel não teria o mesmo impacto emocional senão tivesse sido transformada em canção. A música agenciou uma profunda transformação no relacionamento entre pai e filho. Mas vale notar, que não foi apenas a música que fez isso, foi 
a música gravada no disco, essa música também é outra categoria de música - está ao alcance dos ouvidos, dos olhos e das mãos, registrada num artefato palpável e manipulável. Isac pode carregá-la, mostrá-la aos amigos, escutá-la onde e quando quiser. Seu filho, que antes brincava com o cavaquinho tocando brasileirinho, agora é um compositor respeitado e conhecido na cena musical paulistana.

A música gravada pode viver mais que o próprio artista, pode dar a volta ao mundo sem que o artista saia de casa, pode agenciar eventos que transcendam tudo que o compositor originalmente possa ter imaginado. Um importante produtor musical paulistano, Daniel Ganjaman (produziu, entre outros, o disco Nó Na Orelha do artista Criolo), afirmou que "antigamente você tinha um objetivo bem determinado ao lançar um disco, era fechar com uma gravadora que ia te bancar. Hoje, não dá pra imaginar onde você vai chegar.” (Palestra sobre música independente na FUNARTE, dia 23/03/2012). A trajetória até o primeiro disco normalmente é longa, Rodrigo começou na música ainda criança, "brincando de fazer samba em São Mateus." A brincadeira foi ficando mais séria, e só deixou de ser considerada uma brincadeira por sua família com a gravação do disco.

"Tinha uma roda de samba na rua de casa, os caras mais velhos tinham uma roda e eu devia ter 7 ou 8 anos e comecei a chegar nessa roda ficava ali na rua jogando bola na rua, me chamava a atenção eu ficava ali assistindo os caras tocando... e comecei a conhecer os meninos que também ficavam ali assistindo... eles eram primos dos caras que tocavam, eram primos mais novos da minha idade, comecei a fazer amizade e tal... e toda a vez que acabava o samba, eles pegavam umas latinhas e tal, uns baldes e iam batucar numa pracinha ali perto, brincar de fazer samba e eu comecei a entrar nessa brincadeira com eles, levava o meu balde e queria batucar também... e começou assim essa brincadeira de fazer samba, durou vários anos...." (Entrevista com Rodrigo Campos, 20/05/2011).

Além do reconhecimento dos familiares, a vida profissional de Rodrigo Campos se transformou. De maneira geral, a vida de um músico profissional gira em torno de shows acompanhando artistas (atuação como sideman ${ }^{58}$ ), de aulas (atuação como professor),

\footnotetext{
${ }^{58}$ Sideman literalmente é o músico que fica do lado do artista, é o músico instrumentista que acompanha um artista ou uma banda. Normalmente, ele é um profissional freelancer que trabalha com qualquer um que o contratar.
} 
instrumentista em gravações de outros artistas (atuação dentro de estúdios), e como produtor musical para o mercado de jingles e trilhas de cinema. O disco abre novas possibilidades: no caso de Rodrigo, ele deixou de simplesmente acompanhar outros artistas para ser acompanhado; ele passou a ser valorizado como instrumentista pelo fato de ter gravado diversos instrumentos no seu disco (cavaquinho, violão e percussões) e foi convidado a gravar no disco de outros artistas de renome (em 2010, por exemplo, Rodrigo participou de uma gravação do disco Imagine Project do pianista norte-americano Herbie Hancock com a cantora brasileira Céu); ele passou a ser visto e a se ver como artista e como compositor, ou seja, aquele grava as próprias músicas. Com esse exemplo, temos uma noção de como a gravação de um disco é um processo socialmente rico na medida em que transforma as relações sociais do compositor com seu grupo. Essas transformações são eventos cuja causalidade pode ser expressa na ideia de que os discos são objetos que agenciam relações, ou seja, fazem com que determinados arranjos de interações sociais aconteçam, lembrando, porém, que não são os únicos agentes causais. Conforme vamos descrevendo as situações encontradas na etnografia, outros agentes causais (sujeitos da ação) vão emergindo: o pai de Rodrigo, os jornais e as matérias elogiando o disco, as casas de show, a rádio que premiou o disco.

\subsection{Teoria da Agência e Música}

O disco é um artefato que torna pública a agência criativa de artistas. Essa agência criativa "faz fazer"; no caso de Rodrigo Campos fez ele voltar para a família, fez ele ser reconhecido como outra categoria de músico não só pelo pai, mas pelos jornalistas, pelos músicos que passaram a admirar suas composições, pelos contratantes de shows, pelo público em geral, e por si mesmo ${ }^{59}$. Para dar conta de descrever o lugar do disco na vida de nossos interlocutores, a teoria da agência formulada por Alfred Gell (1998) se mostra bastante profícua, na medida em que nos permite pensar coisas e/ou artefatos como pessoas que agem e/ou sofrem agência. $\mathrm{O}$ autor argumenta que as coisas são agentes, ou seja, fazem eventos acontecerem. Humanos e

\footnotetext{
${ }^{59}$ Latour aborda em diversos textos os fenômenos do "faz fazer." Na sua "Reflexão Sobre o Culto Moderno dos Deuses Fe(i)tiches" (2002), por exemplo, ele mostra que esses objetos mágicos chamados fetiches são um "fazer-falar." Os discos, em especial os suportes físicos, podem ser pensados como fe(i)tiches no sentido latouriano - objetos fabricados, feitos e ao mesmo tempo cultuados e encantados. Os compositores gravam discos porque têm músicas, e fazem músicas para gravarem em discos - realismo e construtivismo juntos.
} 
não-humanos agem uns sobre os outros através de processos contínuos e de mão dupla. Ambos podem ocupar a posição de Agentes e/ou Pacientes numa cadeia de relações. Agentes e pacientes se relacionam nos contextos fugazes e contraditórios da vida social, onde podemos atribuir agência a carros, obras de arte, brinquedos, roupas, imagens e muitas outras coisas. Essas posições são dinâmicas, existe uma transitividade entre agentes e pacientes. Nessa perspectiva teórica o objeto principal da antropologia são as relações sociais, sendo que estas relações podem se dar entre humanos ou entre humanos e não-humanos. Alguém só descobre no que a cultura das pessoas consiste observando e registrando como elas se relacionam com os outros em interações sociais. Refletindo sobre como a antropologia deveria se debruçar sobre a arte, Gell trata as obras de arte como pessoas e estuda as interações entre elas e humanos.

Tratar os objetos como pessoas implica a ideia de que eles não são seres inanimados, eles participam da vida social e podem ajudar a explicá-la. "The immediate 'other' in a social relationship does not have to be another human being" (Gell, 1998:17). Isso, na verdade, já se enunciara de certa forma no pensamento antropológico com Mauss. Mauss (2003), importante referência de Gell, já nos mostrou que as dádivas (na maioria das vezes objetos como braceletes, saias, colares, máscaras etc.) trocadas num sistema de prestações totais não são inertes, elas carregam algo de quem as possuiu, de quem as produziu e trocou num 'potlatch', elas tem uma 'força', um Hau, carregam o Mana, os espíritos de origem. Apesar de não utilizar o termo agência, Mauss é um autor fundamental para refletirmos sobre a natureza da ligação entre objetos e pessoas. No "Ensaio Sobre a Dádiva" um dos argumentos fundamentais é que os sistemas de trocas das sociedades ditas arcaicas são "fenômenos sociais totais" e que:

“[...] exprimem de uma só vez as mais diversas instituições: religiosas, jurídicas e morais - estas sendo políticas e familiares ao mesmo tempo - econômicas - estas supondo formas particulares de produção e do consumo, ou melhor, do fornecimento e da distribuição - ; sem contar os fenômenos estéticos em que resultam esses fatos e os fenômenos morfológicos em que essas instituições resultam.” (Mauss, 2003:187).

Esses "fenômenos sociais totais" colocam os sujeitos em questão numa relação de reciprocidade onde é obrigatório dar, receber e retribuir; os objetos trocados assumem uma força que obriga o recebedor a dar algo em troca. As coisas trocadas assumem uma força que mantêm vivos os laços sociais. Somando a perspectiva de novos teóricos sociais como Gell e 
Latour ao que Mauss nos ensinou, damos um passo além, desconstruindo os sujeitos prontos de antemão. Mesmo humanos precisam ser construídos através das relações onde se inserem. Rodrigo Campos não nasceu artista, ele foi se constituindo e sendo constituído enquanto artista na medida em que sua obra, suas músicas, seus discos trocaram uma serie de propriedades com jornais, jornalistas, ouvintes, familiares, contratantes de show, curadores de arte, sites, computadores e músicos.

Gell trabalha com uma perspectiva nova na qual os objetos não apenas 'carregam', mas produzem, constroem, fazem; os objetos são sujeitos da ação. A força das coisas ganha o nome de agência, e a ênfase nas transações de 'troca' é substituída por uma ênfase na capacidade de 'ação' dos objetos (em especial dos objetos de arte). Ação é o que faz eventos acontecerem, sejam guerras, trocas, casamentos, rituais ou shows de música. Um exemplo que ele traz sobre a agência de um objeto são as pinturas Asmat no escudo de um guerreiro que servem para amedrontar seu inimigo. Uma análise artística tradicional trataria da pintura no escudo em termos estéticos; a abordagem antropológica proposta por Gell trata da pintura em termos de agência ${ }^{60}$. No caso dos discos, uma análise puramente estética observaria suas características musicais e artísticas. A ideia que estamos desenvolvendo aqui é que a antropologia pode (e deve) olhar para os discos como obras de arte que agem. Isso não significa que devemos recusar totalmente o discurso estético, simplesmente, estou analisando os discos numa perspectiva nova, tratando de seu potencial enquanto agente e/ou sujeito actante. Podemos falar sobre o que os críticos musicais falam, mas não devemos nos limitar a falar o que eles falam.

Diversas coisas - obras de arte, carros, brinquedos, armas e roupas - podem exercer agência. Um músico de casamentos me contou uma história interessante que pode exemplificar a agência dos carros em nossa sociedade: ele trocou de carro, trocou um Fiat Idea por uma Mercedes, e quando chegou no casamento onde costumava tocar foi melhor tratado pelos profissionais na entrada do evento (seguranças e manobristas). Antes, quando chegava de Fiat Idea ele tinha que entrar pela porta dos funcionários do buffet onde acontecia o casamento, no

\footnotetext{
${ }^{60}$ Essa recusa do discurso estético é polêmica em Gell. Caleb Faria Alves (2008) considera essa recusa em utilizar o discurso estético uma grande perda para se pensar a arte ocidental. Citando Mauss, Alves propõe que se trabalhe com a nomeclatura nativa, entendendo quem fala e o que fala sobre um objeto ou sobre o que quer que seja. Como analisar a arte ocidental se recusamos os discursos das pessoas envolvidas com elas, inclusive e especialmente os críticos de arte?
} 
dia em que chegou de Mercedes entrou pela porta dos convidados. Nesse exemplo, o carro agenciou uma transformação no modo como o músico era visto. Gell fala nesses objetos agentes em termos de "distributed personhood" (pessoalidade distribuída, tradução minha), ou seja, nós somos nosso corpo e também as coisas que usamos, que vestimos, que produzimos. Somos ainda, as partes destacadas de nosso corpo e que nos presentificam; desde unhas e cabelos, até fotografias e esculturas que nos 'imitam', e, porque não; os carros que dirigimos. Os artistas são os discos que produzem e que tornam públicas suas músicas. A recíproca também é verdadeira, os discos são os artistas, são pessoas. Para explorarmos sua teoria com propriedade, vale a pena passarmos pelo seguinte resumo de seus principais conceitos extraído do final do segundo capitulo The Theory of the Art Nexus do livro Art and Agency.

“A 'teoria antropológica da arte' é uma teoria das relações sociais que se obtém na vizinhança das obras de arte, ou indexes. Estas relações sociais formam parte da textura relacional da vida social dentro de um quadro de referência biográfico (antropológico). As relações sociais só existem enquanto são tornadas manifestas em ações. 'Performers' de ações sociais são agentes e eles agem em pacientes (que são agentes sociais na posição de pacientes vis-à-vis an agent-in-action) Relações entre agentes sociais e pacientes, para os propósitos de uma teoria antropológica de arte, se obtém entre quatro 'termos' (entidades que podem estar em relação):

1. Indexe: Entidades materiais que motivam inferências abdutivas, interpretações cognitivas etc.

2. Artistas (ou outros 'originadores'): para quem é inscrita, por abdução, a responsabilidade causal para e existência e característica do indexe.

3. Recipientes: aqueles em relação com quem, por abdução, os indexes são considerados exercerem agência, ou quem exerce agência via indexe.

4. Protótipos: entidades tomadas, por abdução, para serem representadas no indexe, frequentemente por causa de semelhança na aparência mas não necessariamente." (GELL, 1998:26-27, tradução minha).

Estes são os quatro conceitos principais. Sua noção de objeto artístico (ou obra de arte) é de algo que indexa a agência criativa de artistas. Objeto aparece como indexe: artefato, entidade material, obra de arte. Ao observarmos uma obra de arte, nós por abdução chegamos ao artista, o termo através do qual a entidade material observada se exteriorizou. A noção de recipiente dá conta de todos que entram em contato com determinada obra na posição de espectadores, o público ou a plateia, ou os ouvintes. O protótipo nem sempre está presente numa obra de arte, as vezes ele não existe. Quando um pintor faz um retrato a pessoa retratada é o protótipo da obra. Nas pinturas representativas, quase sempre há um modelo real, este é o protótipo. $\mathrm{Na}$ arte abstrata não existe necessariamente uma entidade no mundo real que serve 
de modelo a ser representado. Gell exemplifica diversas situações possíveis no mundo das artes visuais e analisa cada uma delas utilizando esses conceitos e estabelecendo nexos de relações onde cada conceito ou termo assume uma posição de agente ou paciente. Ele é um autor bastante diagramático, portanto, nessa experimentação prática de sua teoria formularemos diagramas utilizando o símbolo $(\rightarrow)$ para representar o sentido da agência. $\mathrm{O}$ termo $\mathrm{X}$ agindo sobre o termo $\mathrm{Y}$ será expresso a partir daqui como: $\mathrm{X} \rightarrow \mathrm{Y}$. A seguir três exemplos básicos de como ele utiliza seus conceitos numa série de combinações diferentes:

Indexe Agente $\rightarrow$ Recipiente Paciente: "Essa é a formula elementar para espectador passivo" (GELL, 1998:31). Qualquer um que se vê atraído por um indexe e se submete ao seu poder, apelo ou fascinação, é considerado por Gell um paciente respondendo a uma agência inerente ao indexe. Ele cita o exemplo do escudo Asmat que exerce uma agência sobre o inimigo. Escudo (indexe) aterroriza o inimigo (recipiente) numa batalha. A figura terrível do escudo seria um falso espelho que mostra o terror do desenho como o próprio terror da vítima.

Artista Agente $\rightarrow$ Indexe Paciente: $\mathrm{O}$ indexe aparece aqui como um traço congelado da performance criativa de um artista. Esta seria a fórmula elementar da agência artística, onde o indexe motiva a abdução de agência da pessoa que o criou. É a situação de quando olhamos para um quadro e conseguimos afirmar, “Ah, Esse traço é de um Van Gogh!” No campo musical, é quando a marca de um compositor é tão forte que ao ouvir os primeiros acordes já conseguimos descobrir o autor. Trata-se uma perspectiva assumidamente antropocêntrica de Gell, considerando nesse tipo de situação que o único agente é o humano. Porém, o autor fornece outros exemplos, em que o não-humano é agente, invertendo a direção da seta.

Recipiente Agente $\rightarrow$ Indexe Paciente: São os casos em que o espectador aparece como agente. Aqui o recipiente é o patrono que paga por uma obra, uma pintura, uma escultura, um concerto de música, é o agente responsável pela social causation (causalidade social, tradução minha) das obras de arte. Gell fala do público contemporâneo das galerias de arte como espectadores ativos que criam e transbordam sentidos para as obras que apreciam. Eles são espectadores numa posição ativa, reflexo, entre outras coisas, de sua origem socioeconômica, de sua cultura e de seus valores de classe média urbana (liberdade, autonomia individual, responsabilidade pessoal). O público das galerias de arte sente que os objetos ali expostos foram feitos para eles. Uma obra de arte como mercadoria, mercadorias como indexes produzidos a partir da demanda dos consumidores. Um bom exemplo dessa situação no 
campo musical são as trilhas musicais de cinema, o diretor do filme contrata o músico para produzir um material sonoro específico, esse material pode até virar um disco, um indexe na posição de paciente. Walter Garcia (1999), deixa a entender, sem utilizar o conceito de agência, que todo cancionista se vê na delicada posição de tentar agradar sua plateia. Nem mesmo João Gilberto teria escapado dessa interferência da esfera do consumo na gravação do disco Chega de Saudade, considerado o marco inicial da bossa-nova.

"O processo de realização da canção popular-comercial envolve três etapas: composição/produção da obra; veiculação/ divulgação; e consumo. A interferência do consumo, ponto de chegada, já na fase de composição, ponto de partida, não é fato desconhecido, mas talvez cause estranheza quando identificada na bossa-nova de João Gilberto.

Entretanto, "Bim Bom" veste nosso compositor-intérprete no duplo papel de quem atende ao seu coração e seduz a plateia para que aprove seu gesto. Em outras palavras, João Gilberto vive ali o conflito de quem exerce o seu desejo solicitando, para tanto, a concordância do outro. Como resolver esse dilema - a conjunção de arte e consumo que é, enfim, a situação de todo cancionista na indústria cultural?" (GARCIA, 1999: 149).

Garcia não menciona Gell, porém considero bastante próximo neste trecho o que ele chama de "ponto de chegada" do conceito de recipiente. Quando Garcia fala em interferência podemos substituir, sem perda de sentindo, por agência. As plateias agem sobre o compositor e sobre sua obra. Para Garcia é como se João Gilberto assumisse ao mesmo tempo a posição de agente e de paciente em relação à sua obra. A teoria da agência permite diagramar essas relações existentes entre artista - obra de arte - público, lembrando que são relações sociais. O processo criativo que Garcia menciona, no trecho acima, é um processo eminentemente social. O compositor (ou pintor) nunca está criando isolado do mundo, sua arte sempre terá influência de seu meio social, de sua época, de seus costumes, e - lembrando o que já citamos a partir de Geertz - de outras esferas da vida extra-artísticas.

\subsection{Indexe musical - Sobre a natureza da ligação entre artistas e discos}

Indexe é o resultado físico observável da agência de um artista, ao mesmo tempo em que o artista é o resultado observável da agência do indexe. As posições são intercambiáveis. Se os objetos também são sujeitos da ação, e se considerarmos o social como a possessão de tudo por todos (TARDE, [1880] 2006), a troca de propriedades entre humanos e não-humanos; o artista faz um disco e o disco faz o artista. O exemplo de Rodrigo Campos "virando outra 
categoria de músico" nos mostra esse mecanismo de mão dupla. No universo musical, os discos são os objetos físicos onde o artista registra/grava sua agência criativa, ou seja, os discos podem ser vistos como indexes musicais ${ }^{61}$. Eles são o resultado físico observável, mas também audível de um processo de agência artística ${ }^{62}$. Ao tornarem pública a obra de um compositor, esses indexes musicais transformam esse compositor em artista na medida em que estabelecem associações virtuosas com outros mediadores - jornalistas, sites, rádios, blogs etc.

A característica distintiva dos discos é que eles são objetos que apresentam algo para ser ouvido e não apenas observado. Seja como disco de vinil, $\mathrm{CD}$, pendrive, ou de arquivos digitais circulando no ciberespaço, o disco indexa um material sonoro. Esse material sonoro tornado público passa a interferir na vida das pessoas, passa a criar interações sociais transitando entre as posições de agente e de paciente. Ao mesmo tempo em que os artistas compositores agem musicalmente sobre o indexe, tocando e gravando suas músicas nos estúdios, o que poderia ser expresso no diagrama - Artista Agente $\rightarrow$ Indexe (disco) Paciente - o indexe desse fazer musical autoral vai se multiplicar em outros nexos de relações sociais, onde poderá assumir a posição de agente. Vimos acima, um pouco do que aconteceu com Rodrigo Campos depois que ele gravou seu $1^{\circ}$ disco. Num primeiro momento, o próprio compositor agiu, gravando suas composições. O disco São Mateus Não é Um Lugar Assim Tão Longe foi o resultado da criatividade musical do compositor. Mas após esse estágio de produção propriamente dito, o disco passa a agir com uma certa autonomia em relação ao compositor. O indexe se torna agente em nexos de relações sociais que transbordam o que o próprio Rodrigo Campos tinha imaginado. O nexo de relações se complexifica quando observamos o que aconteceu entre Rodrigo Campos, o disco e seu pai:

\footnotetext{
${ }^{61}$ Esse ato de registrar/gravar suas músicas num objeto nunca foi tão compartilhado e acentuado entre os músicos quanto hoje em dia. Isso é resultado, principalmente, de todas as inovações tecnológicas que possibilitaram o barateamento da produção de discos. Gell, assim como a maioria dos antropólogos que estudam arte, não examinou o caso da música, suas análises são direcionadas especialmente para as artes visuais (pintura, escultura e fotografia). No caso dos discos físicos, por serem objetos físicos, palpáveis, imagéticos (carregam fotos, desenhos, pinturas em suas capas e contra-capas) é possível tratá-los como obras de arte visuais e musicais ao mesmo tempo.

${ }^{62}$ Mesmo os discos virtuais, são dotados de materialidade, na medida em que precisam ser 'baixados' na internet, precisam ser 'carregados' em computadores ou tocadores de MP3. Os arquivos digitais ocupam espaço na memória dos computadores, além de que as capas e fotos dos artistas muitas vezes circulam em blogs e sites ao lado dos arquivos digitais musicais. Discutiremos melhor as características dos arquivos digitais no terceiro capítulo.
} 
Artista Agente $\rightarrow$ [[Indexe Paciente] $\rightarrow$ Recipiente Paciente] - Rodrigo Campos produz um disco, artista agindo sobre o indexe. $\mathrm{O}$ disco quando apresentado a seu pai faz com que a escolha do artista de viver da música seja vista de outra forma promovendo uma reconciliação. Indexe exercendo agência sobre o recipiente. Porém, ainda existem outros termos dessa cadeia de relações que são importantes. Os jornais que divulgaram o nome de Rodrigo Campos também agiram sobre o pai nessa reconciliação e nessa verdadeira ascensão do artista a um novo patamar. Ao incluir os jornais que noticiaram o disco, temos o seguinte diagrama:

Artista Agente $\rightarrow$ [[[Indexe Paciente $] \rightarrow 1^{\circ}$ Recipiente Paciente $] \rightarrow 2^{\circ}$ Recipiente Paciente $]$ onde o $1^{\circ}$ Recipiente são os jornais e o $2^{\circ}$ Recipiente o pai de Rodrigo.

Esse encadeamento de termos em relação pode ser interpretado como um novo termo que age sobre o próprio artista num segundo momento. Rodrigo se vê promovido a uma nova categoria de músico aos olhos da mídia e da família. Esse reconhecimento público se estendeu, nos anos posteriores ao lançamento do disco, ao grupo de músicos com os quais Rodrigo passou a trabalhar, e se estendeu ao público crescente de seus shows. O compositor passa então a ser o paciente das transformações que o indexe gerou em sua vida e que ele mesmo não havia imaginado, o que pode ser diagramado de forma resumida como:

Indexe Agente $\rightarrow$ Artista Paciente.

Todos aqueles que conheceram o trabalho do artista através do seu disco, tanto o público nãomúsico quanto os profissionais ligados a música, e que passaram a convidá-lo para trabalhos cada vez mais importantes, podem ser entendidos como recipientes que sofrem a agência do indexe e que depois agem sobre o artista. No caso da gravação de Rodrigo Campos com Herbie Hancock, por exemplo, a agência do disco foi fundamental. Beto Villares, produtor musical renomado e que produziu, entre outras coisas, os discos da cantora Céu, conheceu Rodrigo produzindo São Mateus Não é Um Lugar Assim Tão Longe. A partir desse primeiro contato, reconheceu em Rodrigo um grande artista e um grande instrumentista passando a convidá-lo para outras gravações que culminaram na gravação com Herbie Hancock, considerado um dos maiores pianistas de Jazz do mundo. Interessante que neste encontro com Herbie Hancock Rodrigo gravou percussões e cavaquinho, os mesmos instrumentos que havia gravado em seu disco. Podemos diagramar esse caso da seguinte maneira: 
[Indexe Agente $\rightarrow$ Recipiente Agente] $\rightarrow$ Artista Paciente - onde o Recipiente Agente é o produtor musical Beto Villares que acabou convidando Rodrigo para outras gravações.

Família e profissão foram esferas da vida de Rodrigo Campos diretamente afetados a partir da produção de seu disco de estreia. Ao mesmo tempo que o compositor foi o agente - ele aprendeu como escrever um projeto de lei, ele compôs e reuniu as músicas, tocou vários instrumentos, marcou reunião com produtores, enfim, ele trabalhou muito para conseguir viabilizar a gravação do disco - ele é paciente das músicas e dos instrumentos que o tocaram e o levaram a desejar gravar esse disco. Uma vez que o objeto disco ficou pronto, esse objeto passa a exercer agências em contextos muito mais amplos. O compositor é objeto de sua obra quando ela se destaca de seu corpo assumindo a posição de sujeito em interações sociais, sejam elas com humanos ou não-humanos. Quando digo que o $1^{\circ}$ disco de Rodrigo agiu sobre seu pai, quero dizer que todo processo que resultou no pequeno objeto chamado São Mateus Não é Um Lugar Assim Tão Longe agenciou transformações fundamentais no seu relacionamento com o pai; transformações que somente esse objeto específico poderia engendrar. Discos são, entre outras coisas, registros biográficos dos artistas, retratam momentos específicos de suas vidas, transportam esses momentos para fora do corpo, para fora da performance ao vivo, para fora da rede de contatos interpessoais do compositor.

Os discos também são importantes documentos históricos. Walter Garcia (1999), por exemplo, utilizou inúmeras gravações para construir seu argumento sobre a importância de João Gilberto e de sua batida de violão. Ele teceu uma pequena história musical dos aspectos rítmicos do violão brasileiro, a partir do samba-canção tradicional até chegar à batida da bossa-nova imortalizada no LP Chega de Saudade. Os discos indexam estilos musicais, indexam ritmos e maneiras de tocar, indexam a música de uma época determinada e nos permitem tecer uma história musical. Podemos pensar também no agenciamento propriamente musical dos discos. Quando um disco apresenta uma maneira de tocar inovadora ele pode influenciar uma geração inteira de músicos e compositores. Garcia demonstra que esse foi o caso de Chega de Saudade. Foi nesse disco que João Gilberto apresentou ao Brasil sua síntese rítmica do samba que caracteriza a batida de bossa-nova. Garcia, por meio do depoimento do baterista Milton Banana, nota como a gravação do disco foi polêmica e difícil. Ninguém entendia direito onde João Gilberto queria chegar. Ele brigou muito com Tom Jobim por causa dos arranjos, brigou com os profissionais do estúdio para gravar com um microfone só 
para o violão. Enfim, foi através da gravação desse disco que João Gilberto demonstrou sua forte personalidade artística, Garcia fala no caráter personalista da bossa-nova do artista.

"Voltando à gravação do LP Chega de Saudade, creio que os fatos relembrados, e que já fazem parte da história do mito João Gilberto, podem ser reavaliados segundo uma certeza, firmada para além de qualquer superlativação: a obra bossa-nova de João Gilberto se caracteriza por seu caráter personalista. É o individualismo de um solista que se dá a conhecer, por meio de sua voz e do seu violão."(GARCIA, 1999:152).

Luiz Tatit também ressalta a importância de Chega de Saudade como o instaurador do movimento 'bossa nova' - "a primeira reviravolta musical operada totalmente no domínio da canção popular. (TATIT, 2004:49) Tatit coloca João Gilberto no grau dez da sonoridade brasileira afirmando, em concordância com Garcia, que sua batida de violão sintetizou a harmonia do jazz com a sincopa do tamborim de samba. Vale colocar que da mesma forma que João Gilberto criou essa batida, a própria batida criou João Gilberto. O jazz, o samba, o violão criaram a batida. Quem criou o jazz e o samba? Nesse ponto, recortamos a rede de mediadores e agentes causais. Vai da escolha de nós pesquisadores recortar essa rede que no limite é infinita. Meu ponto aqui é valorizar o papel do disco como sujeito que indexa os fazeres musicais de instrumentistas, intérpretes e compositores tornando-os pessoas públicas, artistas. João Gilberto talvez não teria se tornado esse mito sem a gravação de Chega de Saudade; Rodrigo Campos talvez não teria se tornado o compositor reconhecido que é hoje sem São Mateus Não é Um Lugar Assim Tão Longe.

\subsection{Tatá Aeroplano e a banda Cérebro Eletrônico - Onda Híbrida Ressonante}

Onda Híbrida Ressonante ${ }^{63}$, lançado em 2003 pelo pequeno selo Reco Head records, revela mais aspectos sobre a capacidade de agenciamento do disco enquanto indexe musical. Este primeiro trabalho d banda Cérebro Eletrônico foi produzido de modo caseiro pelo líder da

\footnotetext{
${ }^{63}$ Onda Hibrida Ressonante - "Ano: 2003 Produzido por: Tatá Aeroplano e Fernando Maranho Gênero: Híbrido / Eletrônico

O projeto musical Cérebro Eletrônico, uma homenagem confessa aos discos tropicalistas, foi produzido pelo compositor Tatá Aeroplano e por Fernando Maranho, compositor, produtor e músico multi-instrumentista. "Onda híbrida ressonante" é um trabalho antenado às principais vertentes da música moderna, misturando drum'n'bass com bossa nova, mpb com dance soft, música pop com som indie, hip hop com rock, neurônios com sonoridades criativas, tropicália com marginália e cinema novo com estética digital." (Extraído do site http://www.recohead.com.br/novo/art_cerebro onda.htm dia 24/04/2012 `as 11:32 horas).
} 
banda, Tatá Aeroplano, e pelo guitarrista, Fernando Maranho. Tatá Aeroplano tinha algumas composições e um computador, enquanto Fernando Maranho tinha as guitarras, melodias e outro computador; juntos começaram a produzir as músicas em casa, chamando participações de amigos quando necessário. Ambos, na época, possuíam outros trabalhos, o que garantia certa independência financeira ao projeto de produzir um disco sem apoio de gravadoras. Apesar disso, Tatá conta que Arthur Joly da Reco Head entrou no processo e ajudou no lançamento do disco após ter ouvido as músicas produzidas pela dupla de modo caseiro. Arthur Joly (junto com seu parceiro de selo Marcelo Ozório) viabilizou o surgimento do Reco Head como um selo independente porque também tinha outras fontes de renda ${ }^{64}$. A banda Cérebro Eletrônico só foi montada e realizou os primeiros shows a partir da gravação desse primeiro disco. Pelo que Tatá conta, foi durante o processo de gravação do disco que ele foi arregimentando os músicos e parceiros da primeira formação da banda. Pode-se afirmar, que Onda Híbrida Ressonante agenciou o surgimento da banda Cérebro Eletrônico, isto é, fe ${ }^{65}$ a banda acontecer e entrar num circuito de shows.

“Tatá Aeroplano: O Cérebro Eletrônico (CE) começou em Bragança Paulista, eu e o Fernandão (Maranho) tínhamos uma banda lá, o Gorpiava, e tocávamos com um grupo de amigos de outra banda, o Macacos Sem Pelo, e a gente criou um público, a gente fez uma cena lá... A gente começou o CE em 2001. A primeira formação do CE já contava com o Gustavo Souza na bateria, Fernando Maranho na guitarra que é meu parceiro de Bragança, o Dudu Tsuda, a Helena Rosenthal e Isidoro Cobra. Era um sexteto e nós lançamos o $1^{\mathrm{o}}$ disco Onda Hibrida Ressonante em 2004, e esse é um disco totalmente caseiro, a banda ainda não participou efetivamente desse disco. A banda participou da concepção desse disco passado dum processo todo feito em casa com sample pra realidade. Foi um processo legal até. E nesse meio tempo a gente criou essa dinâmica que toda banda tem! De ensaiar, de fazer, de começar músicas novas, de viajar, e nesse período que a gente começou a trabalhar as músicas do nosso segundo disco Pareço Moderno." (Entrevista com a Banda Cérebro Eletrônico nos bastidores do programa “Ronca Ronca" da Rádio OI FM, dia 18/01/2011).

\footnotetext{
${ }^{64}$ Essa é uma das características desses artistas e dos profissionais envolvidos na gravação de seus discos, grande parte deles possui outros trabalhos e fontes de renda; o disco se torna um projeto artístico independente da lógica da mercadoria que rege as grandes empresas do mercado fonográfico. ${ }^{65}$ Novamente, sobre fenômenos do "faz-fazer" cf, por ex., Latour (2001), especialmente quando este analisa a relação mutuamente generativa entre Pasteur e os micróbios.
} 
Quais as implicações que nos interessam quando Tatá Aeroplano diz que "esse é um disco totalmente caseiro, que a banda ainda não participou efetivamente desse disco"? A implicação fundamental é que a formação efetiva da banda Cérebro Eletrônico, ou seja, uma banda com músicos tocando vários instrumentos ao vivo, é posterior a gravação caseira do disco. As composições reunidas naquele momento por Tatá Aeroplano e por Fernando Maranho, gravadas com amigos, e que deram origem ao $1^{\circ}$ disco, catalisaram a reunião dos músicos: Gustavo Souza, Isidoro Cobra, Dudu Tsuda e Helena Rosenthal. Logicamente, eles já se conheciam, já tocavam juntos em outras bandas e já sabiam que existia uma afinidade tanto em termos musicais quanto de amizade. Porém, o disco possibilitou que essas relações anteriores se desdobrassem numa banda nova, em outras palavras, ele (o disco) exerceu agência sobre os músicos convidados a participar da banda. Da mesma forma que vimos com Rodrigo Campos, que um compositor com disco gravado pode se tornar outra "categoria" de compositor; ser convidado para formar uma banda que já tem um disco pronto, é ser convidado para uma outra "categoria" de banda. Nesse caso, podemos esboçar o seguinte diagrama:

Indexe (disco) Agente $\rightarrow$ Recipiente (banda) Paciente - na medida em que a produção de Onda Hibrida Ressonante no mínimo influenciou positivamente os músicos a aceitarem o convite de Tatá Aeroplano para montarem efetivamente a banda.

Pode-se argumentar que o disco aqui, é um agente secundário. De fato, o agente primário é a dupla formada por Tatá Aeroplano e Fernando Maranho. A banda seria o recipiente primário, que pode ser visto como alvo de agência num primeiro momento.

[[Artista (Tatá e Fernando) Agente $\left.1^{\mathrm{a}}\right] \rightarrow$ Indexe Agente $\left.2^{\mathrm{a}}\right] \rightarrow$ Recipiente $1^{\mathrm{a}}$ (banda) Paciente.

Mas num segundo momento, quando a banda já formada passa a realizar shows para divulgação de Onda Hibrida Ressonante, as plateias dos shows são o alvo final da cadeia de relações que começou na produção caseira do disco. Agora, podemos pensar a banda como um recipiente primário do disco na posição de agente. Como o próprio Gell afirma em seus textos, essas posições nunca são estáveis e fixas. Os conceitos devem ser utilizados e experimentados de acordo com cada situação. O Cérebro Eletrônico vivenciou um longo percurso - a gravação do disco, a entrada dos músicos, os ensaios para transformar o 
repertório do disco num show, o lançamento do disco - até a realização dos primeiros shows. A partir do primeiro show, já com o disco lançado, o diagrama que representa as relações observadas é o seguinte:

$\left[\left[\left[\right.\right.\right.$ Artista Agente] $\rightarrow$ [Indexe Agente] $\rightarrow$ [Recipiente $1^{\text {a }}$ Agente $] \rightarrow$ Recipiente $2^{\mathrm{a}}$ Paciente Onde o recipiente secundário é formado pelas plateias e público consumidor da música do Cérebro Eletrônico que, até então, era constituída pelo repertório gravado em Onda Hibrida Ressonante.

Observando com atenção as folhas do encarte do disco, essa cadeia de relações descrita acima pode ser inferida. As informações relevantes são: a ficha técnica do disco (onde aparecem diversos músicos que eram os amigos da dupla Tatá e Fernando, sendo que nem todos foram convidados a entrar na banda posteriormente), as duas únicas imagens do disco que eram de duas pessoas (Tatá e Fernandão) e uma informação adicional pouco usual em discos "Cérebro Eletrônico ao vivo é: Fernando Maranho, Tatá Aeroplano, Dudu Tsuda, Gustavo Souza, Helena Rosenthal e Isidoro Cobra." Essas informações mostram que a banda não existia ao vivo antes desse primeiro disco e mostram que os músicos que participaram das gravações não eram exatamente os mesmos que formariam a futura banda.

\subsection{Segundo disco como Indexe Paciente}

O segundo disco da banda Cérebro Eletrônico, Pareço Moderno, lançado em 2008 pelo selo PHONOBASE, já contou com uma dinâmica de produção totalmente diferente. A banda já existia, já estava na estrada, e o repertório novo foi sendo tocado ao vivo nos shows antes de ser registrado num estúdio. A produção musical ficou nas mãos de Alfredo Bello, e os arranjos foram feitos coletivamente por todos os integrantes, algo similar aos processos que analisamos em detalhes no primeiro capítulo: Tatá Aeroplano nos vocais e brinquedos, Fernando Maranho nas guitarras, Isidoro Cobra no baixo, Gustavo Souza na bateria, Dudu Tsuda nos teclados. A informação adicional presente em Onda Hibrida Ressonante, de que a banda ao vivo é diferente da banda que gravou o disco, não se faz mais necessária no caso do Pareço Moderno; neste disco a banda ao vivo virou o próprio Cérebro Eletrônico. A foto da capa deixa claro que a banda cresceu incorporando os outros integrantes que não foram retratados no primeiro disco. 
“Tatá Aeroplano: Pareço Moderno foi muito bacana de ser realizado e feito porque foi quando a banda começou realmente a se conectar como uma banda! E esse processo de conexão é uma coisa que é fundamental, porque quando você consegue isso entre os integrantes, primeiro que já tem uma intimidade, uma amizade entre todos integrantes, a sonoridade fica muito mais fácil... então a gente conseguiu ver que com cada canção a gente conseguia dar uma dimensão para ela muito real no show... no palco. E você via que no estúdio a gente conseguia trabalhar legal esses elementos, mas ainda precisava de mais... Mais entrosamento e tudo que veio com a turnê do Pareço Moderno.... E aí, o Rodolfo é importante nisso aí porque o Rodolfo está com a gente desde o começo...

Rodolfo: Não no palco...

GERAL (Todos da banda falando juntos): O Rodolfo é o sexto integrante....

Rodolfo: Não é um (integrante) que o público enxerga assim direto, mas o CE teve essa preocupação de ter um técnico na equipe desde cedo. Eu acho que isso é uma coisa muito legal pra uma banda independente que tem lá todas as suas dificuldades de gerenciar o seu dinheiro... toda sua carreira, não é uma coisa fácil de fazer." (Entrevista com a Banda Cérebro Eletrônico nos bastidores do programa "Ronca Ronca" da Rádio OI FM, dia $18 / 01 / 2011)$.

Um dos fatos centrais que aparece nesse trecho da fala de Tatá Aeroplano é que o entrosamento da banda é fundamental para o processo criativo. Esse entrosamento só se consolidou através de shows ao vivo, e os shows ao vivo só tiveram um começo por causa do primeiro disco gravado em casa, ainda sem uma banda definida. Outra noção importante nesse trecho é a de "sonoridade". As bandas e artistas buscam uma "sonoridade" própria, ou seja, uma identidade sonora, algo que os identifique na cena musical da qual fazem parte. Esta sonoridade se consolida nos shows ao vivo, nos ensaios e na gravação dos discos. É como se fosse uma marca registrada em forma de som. O lançamento dos discos é importante na consolidação de uma sonoridade própria. O terceiro e último disco da banda, Deus e o Diabo no Liquidificador, lançado em 2011, foi feito de modo similar ao segundo, com dois novos integrantes, Renato Cortez no baixo e Fernando TRZ nos teclados. Rodolfo, o sexto integrante da banda que aparece no trecho da entrevista acima, era o técnico de som que acompanhava os shows ${ }^{66}$. A pesquisa de campo contou com a observação de alguns ensaios da banda, onde

\footnotetext{
${ }^{66}$ Importante notar a semelhança da postura de Rodox, técnico de som da banda Cérebro Eletrônico, nessa entrevista com a postura que Lenza, técnico de som do disco Bahia Fantástica, manifestou no
} 
se pode perceber a dinâmica coletiva de criação nos arranjos e ideias musicais. Trata-se do mesmo tipo de criação musical coletiva descrita em detalhes no primeiro capítulo, em especial na parte que tratamos da produção da canção "Perigas Correr" do primeiro disco solo de Tatá Aeroplano. O ponto que vale ressaltar agora é que a música criada e produzida pelo Cérebro Eletrônico hoje, é resultado direto da gravação do primeiro disco. Sem Onda Híbrida Ressonante os outros discos não existiriam e a banda não existiria, pelo menos com o reconhecimento que possui hoje. A rede de causações poderia incluir muitos outros agentes, porém, neste momento em particular, enfatizamos propositalmente as relações causais entre os indexes. Pareço Moderno pode ser visto como um indexe na posição de paciente em relação ao primeiro disco.

Bahia Fantástica, segundo disco de Rodrigo Campos também pode ser visto dessa forma. A banda que gravou esse segundo trabalho de Rodrigo Campos foi formada com músicos que passaram a admirar e respeitar o trabalho do compositor realizado no primeiro disco. Todos são admiradores de São Mateus Não é Um Lugar Assim Tão Longe. Participar do segundo disco de um compositor que se mostrou tão talentoso num primeiro disco é visto como uma grande alegria por todos os músicos que participaram de Bahia Fantástica ${ }^{67}$. Rodrigo Campos, em matéria publicada pela Folha de São Paulo sobre o novo disco, diz: "Pela falta de recursos os amigos entram pra tocar, acaba dando nisso ai ${ }^{68 \%}$. O que não aparece na matéria é que esses amigos são músicos que conheceram Rodrigo a partir do primeiro disco. Ouso afirmar que o primeiro disco sempre exercerá algum tipo de agência na futura obra de um artista; o primeiro disco sempre agirá sobre o segundo e assim sucessivamente, tanto em termos artísticos, quanto em termos sociais. Essa hipótese pode ser expressa no seguinte diagrama:

Indexe $1^{\text {a }}$ Agente $\rightarrow\left[\left[\left[\left[\right.\right.\right.\right.$ Indexe $2^{\text {a }}$ Paciente $] \rightarrow\left[\right.$ Indexe $3^{\text {a }}$ Paciente $] \rightarrow\left[\right.$ Indexe $4^{\text {a }}$ Paciente $] \ldots$ e assim sucessivamente.

diálogo transcrito no primeiro capítulo. Eles dialogam com os músicos como se fossem também artistas.

${ }^{67}$ No site "YouTube", existe um vídeo sobre o processo de produção de Bahia Fantástico que ilustra um pouco da relação dos músicos convidados com a obra do Rodrigo Campos. O vídeo pode ser visto no seguinte endereço eletrônico http://www.youtube.com/watch?v=65MWP qDcx0.

${ }^{68}$ Matéria publicada pelo jornal, Folha de São Paulo, na Ilustrada, em 11 de Abril de 2012, assinada pelo jornalista Marcus Preto. 
Artisticamente, um disco exercerá agência sobre o próximo na medida em que o artista sempre busca se renovar e se superar. Tatá Aeroplano considera seu disco mais recente, seu primeiro disco solo e o primeiro sem o Cérebro Eletrônico, como seu trabalho mais maduro. Ele buscou se renovar chamando outras pessoas para participarem da produção. Como vimos no primeiro capítulo, Tatá Aeroplano convidou o produtor musical e multi-instrumentista Dustan Gallas, e o guitarrista Junior Boca para gravarem suas novas composições.

As canções do disco Tatá Aeroplano possuem um tom confessional muito intenso; o compositor narra cenas e histórias reais que retratam seus relacionamentos, como na canção "Par de Tapas". Nessa canção, por exemplo, encontramos vários pontos que podem ser considerados inovadores em relação ao disco anterior do Cérebro Eletrônico. O primeiro ponto digno de nota nessa música é sua longa duração quando comparada às composições anteriores do artista. Ela tem mais de dez minutos de duração e descreve em detalhes uma briga entre um casal que começa na rua Augusta e termina em sexo. Outros pontos a se notar são que a composição não possui um refrão e nem repetição melódica, ao passo que a base rítmica e harmônica permanece contínua e regular durante quase toda música.

Bahia Fantástica de Rodrigo Campos também foi influenciado por São Mateus Não é Um Lugar Assim Tão Longe. Os títulos desses dois discos já denunciam uma influência do primeiro sobre o segundo, ambos falam de lugares. Rodrigo foi bem sucedido falando de um lugar familiar, seu bairro de infância. No segundo disco, o compositor permanece compondo sobre um lugar, porém dessa vez um lugar distante que o compositor visitou pela primeira vez recentemente. Musicalmente, a dinâmica coletiva de arranjos predominou gerando uma massa sonora bastante diversa do que Rodrigo produzira com Beto Villares no primeiro disco. O primeiro disco é mais acústico, com o uso acentuado de violão, cavaquinho e instrumentos percussivos utilizados no samba. O segundo disco, como o próprio compositor avalia, é mais "psicodélico", com menos percussão, mais "guitarras e sonoridades elétricas" (especialmente os órgãos e teclados tocados por Mauricio Fleury). Lugares, bairro de infância, violão, cavaquinho, instrumentos percussivos, samba, psicodélico, guitarras e sonoridades elétricas são outros agentes não-humanos envolvidos na enorme rede de relações que caracteriza esses fazeres musicais.

Quando dizemos que um objeto exerceu agência sobre alguma coisa, no fundo estamos afirmando que sem aquele objeto determinado, os eventos subsequentes não aconteceriam 
daquela determinada forma. Esses eventos podem ser trocas cerimoniais numa sociedade melanésia, podem ser rituais xamânicos entre populações indígenas sul-americanas, podem ser shows de música em São Paulo. Mas qual a vantagem desse tipo de abordagem? Que tipo de conhecimento podemos obter refletindo sobre a agência social de humanos e nãohumanos? Uma das vantagens é que ela permite uma reflexão antropológica inovadora dos mais variados eventos sociais. Inovadora porque nos permite uma análise rica da vida social sem sobrecarregar noções tradicionais de 'cultura', 'sociedade', 'símbolo' e 'significado'. Não estou afirmando que essas noções devem ser evitadas, apenas coloco que a centralidade da noção de agência nessa análise nos permite uma perspectiva inédita. Inovadora também porque nos permite sair do antropocentrismo científico onde as análises se configuram via de mão única onde humanos são sempre os grandes sujeitos dos fenômenos e os não-humanos os entes passivos objetos da ação. Outro ponto vantajoso é que a noção de agência permite reconfigurar os discos, caracterizando um fazer musical urbano contemporâneo, num momento de crise na indústria fonográfica e de barateamento das tecnologias de produção musical.

Kiko Dinucci é um dos jovens compositores paulistanos que começou a lançar discos dentro desse contexto. Ele conta que depois que percebeu como é fácil lançar um disco, hoje em dia, deseja lançar dois por ano. Ele compõe pensando no formato e no suporte disco, e assim que termina um, já pensa no próximo. A gravação de um disco está se tornando um fenômeno musical tão comum, que fica difícil imaginar alguém compondo uma canção nova sem a intenção de gravá-la.

\subsection{Kiko Dinucci - "Pau pra toda obra"}

Kiko Dinucci é um dos jovens compositores paulistanos mais ativos quando se trata de gravar suas próprias composições. Nascido em São Paulo, em 1977, o compositor se considera ligado "diretamente com a musicalidade paulista e paulistana, influenciado por compositores como Adoniran Barbosa, Paulo Vanzolini, Geraldo Filme, Raul Torres e compositores contemporâneos como Itamar Assumpção, Luiz Tatit, Wandi Doratioto, entre outros ${ }^{69}$." Ele já lançou os seguintes discos autorais: Padê com a cantora Juçara Marçal em 2007, Kiko

\footnotetext{
${ }^{69}$ (Extraído do site: http://kikodinucci.multiply.com/?\&show interstitial=1\&u dia 30/04/2012 as 14:53 horas.)
} 
Dinucci e Bando Afromacarrônico em 2008, O retrato do artista quando pede DUO MOVIOLA (Kiko Dinucci e Douglas Germano) em 2008, Na boca dos outros em 2010, Metá-Metá (Kiko Dinucci, Juçara Marçal e Thiago França) em 2011, esses quatro últimos lançados pelo selo Desmonta. No final de 2011, Kiko lançou o Passo Torto um trabalho realizado junto com Rômulo Fróes, Rodrigo Campos e Marcelo Cabral, lançado através de uma parceria entre os selos Phonobase e YB music. Em 2012, lançou o Metal Metal, segundo disco do grupo Metá-Metá. Em 2013, lançou o Passo Elétrico, Segundo disco do grupo Passo Torto.

Foram oito discos lançados em aproximadamente 7 anos. Uma produtividade muito alta, aliada a uma grande capacidade de estabelecer parcerias, visto que nenhum dos trabalhos é totalmente solo. Como já mencionamos no início do texto, Kiko Dinucci também produziu um documentário chamado Dança das Cabaças, onde explora Exu na religiosidade afrobrasileira, e ainda encontra tempo para se dedicar às suas gravuras (algumas das quais já viraram capas de discos). Toda sua arte traz muitos elementos afro-brasileiros, em especial do Candomblé. "A minha experiência na religião é de vivência mesmo... Eu sou o que chamam de Abian... lá no meu terreiro eu já sou um Alaian, um cara que toca tambor." (Entrevista com Kiko Dinucci, dia 06/06/2012). Ele é do Candomblé, ele pratica a religião. Suas gravuras e algumas composições celebram o panteão de orixás do Candomblé. Um exemplo etnográfico dessa religiosidade encontrei assistindo a um show no Centro de Cultura Judaica, em São Paulo, dia 15 de Maio de 2011. O show fazia parte de um projeto sob curadoria de Benjamin Taubkin, renomado músico paulistano, cuja ideia central era reunir músicos de diferentes culturas e países. Nesse dia, Kiko Dinucci e o saxofonista Thiago França dividiram o palco com o baixista israelense Omer Avital. A primeira música do show foi uma espécie de improvisação em tom menor, num compasso de 6/8 típico de levadas rítmicas africanas. Kiko cantou um tema em cima da improvisação coletiva, e ao final da música contou para a plateia que se tratava de um canto para Exu que servia para "abrir os caminhos" - abrir os caminhos para que eles tivessem um bom show juntos. Numa visita a sua casa no bairro do Cambuci, Kiko tocou vários ritmos do Candomblé no atabaque. Ele toca atabaque nas cerimônias da casa de Candomblé que frequenta, o que explica, em parte, sua fluência rítmica ao violão. As influências religiosas no disco do Bando Afromacarrônico são claras, tanto nos ritmos e melodias, quanto nas letras como por exemplo na $2^{\mathrm{a}}$ faixa do disco, música Padê Onã de Douglas Germano, grande parceiro de Kiko Dinucci. A música já começa com uma saudação para Exu, Laroiê: 


\section{Laroiê Bará}

Abra o caminho dos passos

Abra o caminho do olhar

Abra o caminho tranquilo pra eu passar

Laroiê Eleguá

Dobra o mal de joelhos

Só levantando o ogó

Dobra a força dos braços que eu vou só

Laroiê Legba

Guarda ilê, onã, orum

Cobá xirê dsse funfun

Cuida de mim que eu vou pra te saudar

Kiko Dinucci se deixa influenciar bastante pelo Candomblé esteticamente. É quase como se o candomblé e suas matrizes estéticas servissem como protótipo de uma parte considerável de sua arte. Porém, suas fontes inspiradoras são as mais variadas possíveis. Ele tem música que fala de bairro, música que fala de morte, música que fala da vida de um artista em São Paulo. A temática religiosa é forte, mas não é a única. Fazendo um paralelo com as artes visuais, diria que Kiko Dinucci é um compositor altamente representativo, ele compõem canções representativas, ou seja, canções inspiradas em imagens e histórias reais que o compositor viveu. Se suas músicas fossem pinturas, seriam pinturas mais realistas e representativas do que abstratas. O paralelo com artes visuais não é gratuito nesse caso específico, na medida em que o compositor é também um grande artista plástico. Kiko Dinucci me contou que sempre parte de uma imagem, até mesmo para compor canções; sua música é imagética, cinematográfica. Apesar deste capítulo falar essencialmente da agência dos discos, Kiko Dinucci é o compositor, dentre os três analisados aqui, que atribui menor importância aos discos quando fala sobre sua carreira na música. Para ele, o fundamental é a originalidade do trabalho.

“Originalidade é você criar a partir de outras referências a sua assinatura artística, um resultado que só você consegue alcançar, essa assinatura pode mudar com o tempo, como uma assinatura comum. É a busca pelo diferente, pela surpresa, fruto da inquietude. Uma 
obra original deve surpreender até o próprio autor. O disco é importante na medida em que divulga seu trabalho." (Entrevista com Kiko Dinucci, dia 20/05/2013. Grifos meus.).

Na última frase do artista nos deparamos novamente com uma das coisas mais interessantes que essa etnografia traz para discussão: o disco como sujeito da ação. Kiko Dinucci elabora uma frase onde reconhece que é o próprio disco quem divulga trabalho e não o artista. Ele também valoriza bastante as possibilidades de divulgação através das redes sociais, apontando que o surgimento das redes sociais precede a internet.

“As redes sociais são o grande divisor. A internet é legal, tudo bem! Mas no punk já rolava rede social. Todo show já tinha barraquinha de merchandising. No Napster a gente baixava MP3, tudo bem, do Metálica, das bandas grandes... Mas as redes sociais que propiciam os independentes ficarem conhecidos." (Kiko Dinucci na Palestra sobre música independente na FUNARTE, dia 23/03/2012).

Ele mencionou, nessa mesma palestra, a importância dos blogs na divulgação de seus discos no ciberespaço, afirmando que montou uma lista de blogs para os quais manda sempre seus lançamentos. Cada blog que comenta seu trabalho e disponibiliza seu disco para download é um multiplicador de seu público ${ }^{70}$. Essa cadeia formada junto aos blogs pode ser expressa no seguinte diagrama:

$\left[\left[\left[\right.\right.\right.$ Artista Agente $\left.1^{\mathrm{a}}\right] \rightarrow\left[\right.$ Indexe (disco) Agente $\left.2^{\mathrm{a}}\right] \rightarrow\left[\right.$ Recipiente $1^{\mathrm{a}}$ (Blogs) Agente $\left.3^{\mathrm{a}}\right] \rightarrow$ Recipiente $2^{\mathrm{a}}$ (Internautas no ciberespaço) Paciente.

Por mais que Kiko, quando fala sobre seu trabalho, reforce a importância da originalidade do trabalho e da qualidade artística, os discos ocupam um lugar central no seu fazer musical. A prova mais óbvia dessa importância é a quantidade de discos lançados ao longo dos últimos cinco anos. Enquanto escrevo essas palavras, Kiko provavelmente está pensando nos

\footnotetext{
${ }^{70}$ Um exemplo de blog que já divulgou discos de Kiko Dinucci é o “Já Ouviu?" Vale a pena conferir a análises do disco Metá-Metá presente no blog. Pela falta de espaço reproduzo aqui somente o parágrafo inicial sobre a idéia geral do blog."O "Já Ouviu?" é uma iniciativa de duas amigas pesquisadoras e apaixonadas por música brasileira. A ideia é fazer do blog um lugar para falarmos da produção musical nacional contemporânea sem a pretensão de dar conta de toda sua complexidade, e sim de apontar aquilo que gostamos, achamos relevante ou simplesmente tratar de um artista sobre o qual tivemos vontade de escrever." Extraído do site: http://jaouviu.com/about/ dia 09/06/2012 as 19:36 hrs.
} 
próximos discos que vai gravar. Outro exemplo que vale a pena trazer neste momento, é uma entrevista concedida no programa Metrópolis da TV Cultura ${ }^{71}$ que é totalmente pautada pelos discos lançados. O entrevistador comenta os discos, um a um, enquanto pede para Kiko Dinucci tocar uma música de cada. A carreira, as composições, as histórias de vida, a religião são temas que vão surgindo na entrevista orbitando ao redor da apresentação dos discos. Cada disco mostra um Kiko diferente, o entrevistador brinca quando Kiko canta uma música do Duo Moviola depois de ter tocado uma música do Afromacarrônico, dizendo que são "dois Kikos diferentes". Os discos se confundem com a própria pessoa, a pessoa Kiko Dinucci se multiplica (ou se divide?) em seus discos. Estes, são pauta constante para as mídias tradicionais - como TV, Rádio e Jornais - e agenciam essas interrelações artista-mídia.

"Kiko Dinucci: Eu acredito que eu sou o cara que mais lança disco da minha geração, não tenho muita dúvida... eu vou lançar o sétimo e o oitavo disco esse ano. Eu lancei seis discos em quatro anos, nesse ano vão ser mais dois, então é mais que um por ano né?

Disco sempre dá muito trabalho, mas por outro lado, pra mim tá cada vez mais fácil gravar. Se eu tiver 1.500 reais no bolso eu gravo um disco, pra mim o meu preço de estúdio é esse. Entro lá ensaiado, 123 4, dois takes pra cada música e depois vou gastar mais um pouco com a mixagem e com a masterização. A capa posso dar para algum amigo fazer e a grana eu dou depois.

Eu: A do Passo Torto foi você quem fez, né?

Kiko Dinucci: Fui eu quem fiz. Eu fiz a gravura num dia, a capa no outro, no outro a gente já mandou pra fábrica." (Entrevista com Kiko Dinucci, dia 06/06/2012).

Como já mencionamos no primeiro capítulo, Kiko Dinucci domina quase todas as etapas de produção dos seus discos. O que ele não domina em termos técnicos (mixagem e masterização) tem um custo relativamente barato hoje em dia. Ele me afirmou, nesse mesmo dia, que a maioria dos músicos é alienada, só pensa em música e partitura. $O$ artista, diferentemente do músico, é aquele que está conectado com o mundo de forma mais ampla. $O$ artista tem uma obrigação intelectual, ele tem que dialogar com outras formas de arte como cinema, literatura, artes plásticas. Kiko Dinucci é um exemplo claro desse diálogo. A parte

\footnotetext{
${ }^{71}$ Entrevista dividida em duas partes de aproximadamente 7 minutos, que pode ser conferida no site: http://mais.uol.com.br/view/xiddtuwnvlqs/metropolis--kiko-dinucci-04021A3860C8A18307?types=A publicada 16/12/2010 as 12:05 hrs.
} 
técnica se resolve com 1.500 reais. A parte criativa transborda no seu fazer musical marcado pela originalidade. Suas músicas comunicam muita coisa por si mesmas, os arranjos e o estúdio de gravação não precisam ser os melhores do mundo. Isso está ligado também à sua atitude punk do "faça você mesmo" com o que estiver ao seu alcance. Kiko já tocou em banda de punk e já foi bastante ligado ao movimento punk. Seu samba, é um samba punk, é um samba que incorpora "os ruídos, as sujeiras" de uma gravação de disco às pressas e com pouco dinheiro, é um samba que precisa de pressa porque comunica aquilo que o compositor presenciou ao atravessar a rua. Sua música reflete o presente e as imagens do momento.

"Eu tenho muita coisa pra mostrar... sinto como se fosse um aborto você ter uma ideia e depois você ficar, ah eu quero fazer esse disco assim... e de repente daqui há três meses sua vida muda e você já esqueceu toda aquela ideia... Eu acho que tem que gravar! Por exemplo, eu tenho um disco com o Thiago França gravado, a gente nunca lançou, a gente vai lançar talvez mês que vem, é um disco de improviso livre, experimental ao extremo, mas é um disco! A gente entrou uma tarde no estúdio e gravou. Gravou! Isso é o que importa, é que foi registrado isso, entendeu?! Não se perdeu. Mesmo que você não lance um disco agora, você tem que registrar suas ideias. Eu tô afim de fazer um EP agora que vai ter duas músicas com temas atuais, uma falando de juros de banco e a outra que fala do facebook. Eu não posso demorar para gravar isso porque não sei se vai ter facebook daqui a meio ano. Eu vou fazer um esquema de entrar gravar e já por na internet no dia seguinte sabe?! O nome do EP vai se chamar Antes Que O Mundo Mude." (Entrevista com Kiko Dinucci 23/03/2012. Grifos meus.).

Um EP é uma gravação, em Vinil ou CD, com duração media entre 15 a 30 minutos, e com 4 a 7 músicas. É um disco de menor duração que um disco normal e de maior duração que um Single (que normalmente tem uma única música). Chama atenção, nesse depoimento de Kiko, o caráter emergencial da gravação e do título do EP. Ele precisa gravar e lançar rápido antes que os assuntos que trata nas canções se transformem. Essa rapidez em gravar e lançar um disco é um fenômeno relativamente novo no mundo musical, uma decorrência do domínio das tecnologias de gravação pelos músicos e das possibilidades de divulgação através das redes sociais na internet. Essa etnografia vem apontando que esses dois fatores associados, domínio da tecnologia e redes sociais na internet, tornam a gravação de discos um aspecto central no fazer musical dos compositores. Kiko acentua esse fato na sua prática musical cotidiana como poucos. Por isso, ele afirma com tanta ênfase: "Gravou! Isso é o que 
importa..." Um músico tem que gravar! Trata-se de uma espécie de imperativo artístico para que seu fazer musical entre num novo patamar, para que ele passe a ser reconhecido e se reconheça como artista.

Ao longo da pesquisa de campo, em entrevistas, conversas informais, ensaios, gravações, shows, nenhum dos artistas e dos músicos das respectivas bandas colocou a importância da vendagem dos discos como motivação principal para gravarem. Mesmo que não vendam seus discos, eles vão continuar produzindo, compondo e gravando. $\mathrm{Na}$ entrevista supracitada do programa Metrópolis, Kiko brincou que literalmente lança seus discos; ele lança para o alto e “o disco é de quem pegar!” De modo geral, esses artistas deram muitos discos. Lógico que eles não dão para qualquer um, mas pelo menos metade das unidades prensadas de cada disco acaba sendo oferecida gratuitamente para jornalistas, $b \log s$, amigos, familiares, músicos etc. Pensar nos discos como produtos para serem vendidos e cuja receita sustenta a vida do músico não faz sentido nesse contexto de pesquisa. O disco é muito mais do que um produto para ser vendido na prateleira de uma loja.

A experimentação com a teoria de Alfred Gell buscou justamente uma perspectiva que reconfigurasse os discos valorizando sua capacidade de agenciamento, valorizando seu papel de mediação na rede de sujeitos envolvidos nesse fazer musical. Mediação aqui entendida na sua versão latouriana como algo que atua, que produz, que age e não como algo que simplesmente conecta polos opostos. O disco enquanto mediador está no meio de processos sociais de produção musical. Observamos as relações sociais que se estabelecem ao redor desses artefatos e identificamos múltiplos agenciamentos que transcendem os aspectos mercadológicos, musicológicos e até mesmo as motivações individuais de cada compositor. Um disco nos conta histórias; histórias de vida, histórias de família, nos conta como uma banda foi montada, nos conta como um compositor conheceu o outro e influenciou sua musicalidade, nos conta como é importante a amizade para se obter uma boa sonoridade de banda, nos conta como uma batida de violão pode revolucionar a música de uma época. Os casos dos artistas analisados aqui, nos mostraram essa variedade de histórias por trás da produção de discos. 
Rodrigo Campos, Tatá Aeroplano e Kiko Dinucci buscam formas alternativas de viabilizarem seus discos e afirmam que com isso possuem uma autonomia criativa. Tosta Dias (2000) mostrou como as grandes gravadoras controlavam todas as etapas da produção fonográfica e da circulação de música até o final dos anos noventa do século passado; as grandes Cias musicais eram as "donas da voz" que tocaria nas rádios e televisões de todo país, "donas da voz" que estaria na prateleira das lojas de discos, "donas da voz" que tocaria nas pistas de dança de boates e boates, "donas da voz" que seria ouvida nos shows ao vivo da maioria das casas de show do pais. Mesmo reconhecendo, já no início dos anos dois mil, a fragmentação e terceirização das etapas produtivas da indústria fonográfica, a autora enfatiza o monopólio que as grandes Cias fonográficas possuem sobre os principais canais de divulgação e circulação da música. Esse monopólio ainda existe, porém ele convive com uma cena autônoma de música cada vez mais forte que se apropria das redes sociais na internet de uma forma inteligente e eficaz para divulgarem sua produção. $\mathrm{O}$ artista Curumin, por exemplo, em sua página de artista no facebook, postou, dia 11 de Junho de 2012, o comentário: "80 mil plays no Arrocha! Valeu Galera! Logo mais tem clipe novo!" Ele comemorava 80 mil acessos online no seu mais novo disco, Arrocha, via soundcloud, um site para compartilhamento digital de música. Kiko Dinucci, em entrevista para o site "Scream \& Yeall", falou sobre o sucesso do lançamento digital do disco Metá-Metá através da plataforma Bagagem.

"Pra gente foi legal porque é um diferencial lançar o disco no meio digital. A ideia é também dar preferência aos blogs, ao mundo virtual. Nós só mandamos fazer o CD [do "Metá Metá"] agora, cinco meses depois, no show de lançamento. Isso mostra que você não precisa mais mandar um CD para a fábrica para existir. Pros blogs é um prato cheio. Nós mandamos o material para eles: release, músicas, encarte... É muito mais honesto porque o cara do blog escreve porque está muito a fim. Eles começam a fazer barulho pela blogosfera e acaba chegando na mídia tradicional. Antigamente, o álbum mais conhecido era o do AfroMacarrônico ("Pastiche Nagô", 2010), mas o "Meta Metá" foi o que teve mais repercussão. Foram mais de 30 mil downloads desde maio. Se eu fosse fabricar, não ia conseguir vender. Eu ia ficar com um monte de caixas aqui em casa, não ia conseguir me livrar deles nem se eu saísse distribuindo pelas ruas." (Extraído do site: http://screamyell.com.br/site/2011/10/26/entrevista-kiko-dinucci/, dia 12/06/2012 às $14: 38$ hrs.) 
Importante reconhecer a diferença de proporção entre o poder econômico que as grandes corporações da indústria fonográfica ainda possuem e o poder econômico desse grupo de artistas que atuam de forma autônoma se apropriando das novas tecnologias de produção e de divulgação via internet. Se analisarmos alguns números básicos teremos dimensão dessas diferenças. Tatá Aeroplano prensou 2.000 cópias de seu disco desde o lançamento em 2012 e ainda não vendeu todas até a redação dessa dissertação em meados de 2013. Roberto Carlos, com o disco Esse Cara Sou Eu, lançado em 2012, alcançou a melhor marca entre artistas nacionais do mainstream com 1.500 .000 cópias vendidas ${ }^{72}$. Citei esse exemplo extremo de Roberto Carlos para deixar claro que estamos falando de pesos e medidas completamente diferentes. O mainstream apesar de todas as crises continua existindo, continua perpetuando um modelo produtivo baseado numa enorme divisão social do trabalho, baseado no disco como produto a ser comercializado, baseado nas leis de direitos autorais tradicionais. $\mathrm{O}$ universo estético sertanejo, para citar outro exemplo extremo, vem se renovando e produzindo artistas de grande sucesso comercial, especialmente entre o público jovem. A artista de sertanejo universitário Paula Fernandes foi a segunda melhor colocada em vendas de disco em 2012, alcançando 400.000 cópias com o disco Meus Encantos ${ }^{73}$.

O que esta etnografia permite identificar não é o fim do mainstream e nem o fim do disco enquanto produto comercial, estamos identificando que paralelamente ao mainstream, existe um amplo grupo de artistas que não são absorvidos pelas grandes gravadoras que estão controlando de forma autônoma suas carreiras e estão conseguindo produzir discos com mais qualidade técnica e maior circulação via redes sociais. É como se os "donos da voz" finalmente fossem também os artistas, reconhecendo que essa voz ainda tem um peso pequeno comparado ao peso da voz das grandes gravadoras, a voz do mainstream. Os discos virtuais se propagam de modo viral no ciberespaço via blogs, sites de compartilhamento, facebook etc. Nesse contexto, a padronização e repetição de formas musicais que marcou a indústria fonográfica de massa convive com uma produção musical marcada pela singularidade criativa de cada compositor. Um compositor que financia seus próprios discos, gerencia sua própria carreira e grava o tipo de música que quiser. Teríamos chegado, finalmente, na era da "arte pela arte, a música pela música?"

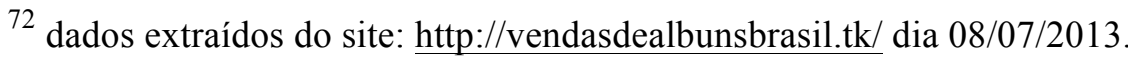

${ }^{73}$ Ibidem.
} 
Este é o discurso desses três jovens compositores. Eles afirmam que gravam discos pela arte, porque têm algo a ser comunicado, eles precisam comunicar, "botar para fora", senão "é como se fosse um aborto" criativo. Tatá Aeroplano me disse em várias ocasiões: "Eu estou tranquilo, porque hoje se você tem uma boa canção você tem tudo..." Você tem tudo justamente porque as principais ferramentas produtivas do mundo musical estão ao alcance de todos. Só não estaria tranquilo quem não têm uma boa canção, quem não tem uma arte de qualidade. É impressionante que, mesmo sem se conhecerem com intimidade, Kiko Dinucci e Tatá Aeroplano manifestem algumas ideias e valores similares. Kiko Dinucci e Rodrigo Campos são amigos próximos e também estão tranquilos com seus caminhos artísticos, com suas carreiras. Seus shows estão cada vez mais lotados; cada vez mais blogs divulgam suas músicas, cada vez mais gente os admira. Os três conseguiram uma projeção nos grandes jornais de São Paulo sem estarem vinculados a uma grande gravadora, conseguiram entrar na disputada programação das diversas unidades paulistas dos SESCs.

Esse discurso da arte pela arte está ligado a um fazer musical que valoriza o autor de composições originais. Originais no sentido de inéditas, mas também no sentido de inovadoras. A gravação de um disco é o processo através do qual essa originalidade ganha vida. O disco garante que as músicas e o nome do compositor se propaguem. Por trás do discurso da arte pela arte, está em jogo também a necessidade de alimentar um mercado musical com produtos novos. Esses jovens compositores sabem que é importante continuar gravando para manterem seus nomes no mercado e para alimentarem o circuito de shows com performances que se renovam a cada lançamento. Apesar de não declarada, existe uma preocupação mercadológica por trás de cada disco. O que a etnografia mostrou é que essa preocupação mercadológica convive com uma lógica distinta onde a originalidade artística também é valorizada. O que observamos no caso da produção musical analisada aqui, é um equilíbrio maior entre duas lógicas de produção fonográfica: uma lógica mercantil e uma lógica artística. $\mathrm{O}$ disco ganhou uma relevância maior na vida desses artistas justamente porque agora é mais fácil gravá-los e divulgá-los. O quadro a seguir busca representar a centralidade do disco e sua ligação com os principais termos utilizados ao longo deste capítulo: artistas, fazer musical, novas tecnologias, redes sociais na internet, shows e público. 


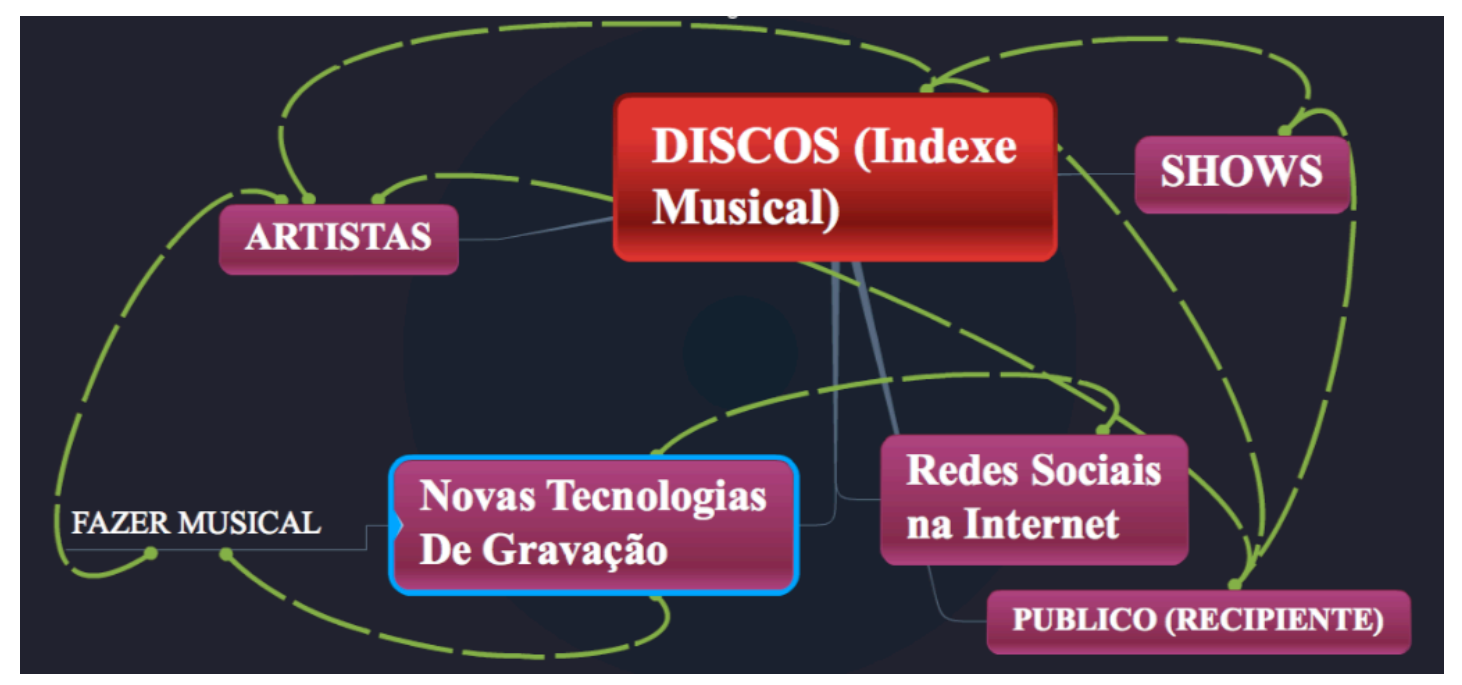

Rodrigo Campos, Tatá Aeroplano e Kiko Dinucci representam um grupo muito maior de compositores para os quais o disco é elemento fundamental da criação artística. O disco é o objeto que engendra as relações sociais desse fazer musical; um fazer musical urbano contemporâneo gerativo de canções originais. Tornou-se um pré-requisito para cancionistas da cena musical paulistana circularem nos principais espaços de show de música. Ao mesmo tempo em que é alvo da agência dos compositores e músicos, ele agencia transformações profundas nas cadeias de relações sociais nas quais estão envolvidos. Ao mesmo tempo em que permanece mercadoria, conquistou autonomia enquanto obra de arte. A seguir, veremos como esses discos agem no ciberespaço quando são compartilhados principalmente em forma de arquivos de MP3. 


\section{CAPÍTULO 3}

\section{Cibercultura e música: sobre discos virtuais e usos da internet}

“Gosto de trabalhar com minhas máquinas porque é uma maneira de estar sozinho sem estar sozinho. As máquinas fazem parte e uma ecologia da natureza humana. Quando somos um com uma máquina, estamos conectados com todas as máquinas e com todas as outras pessoas que tocam numa máquina. Somos um com a natureza humana, e é uma sensação reconfortante ser parte de uma ecologia de pessoas conectadas por máquinas e máquinas conectadas por pessoas. O que eu gosto nas máquinas é a intimidade distanciada que posso estabelecer e manter entre os outros e eu. Posso estar sozinho com mais alguém. Posso sair

de meu corpo e estar bem próximo sem tocar a carne. Carne-a-carne é uma coisa, estar sozinho com outra pessoa sem se tocar é outra. A natureza humana está ligada a máquinas de todos os tipos. É um mundo que envolve um mundo de outras espécies e outros tempos. É um ponto de vista que depende de uma solidão compartilhada, um prazer que vem de estar sozinho com outras pessoas."

(Tom Sherman “MACHINE R US...” In: A Arte no Século XXI: A Humanização das Tecnologias.)

Este capítulo discute - a partir da etnografia dos discos em construção e das análises precedentes sobre a agência dos discos - o processo de digitalização dos conteúdos musicais, como os discos agem na internet e como as novas práticas comunicacionais no ciberespaço influenciam os fazeres musicais contemporâneos. As questões principais que envolvem essa análise são: De que forma o ciberespaço é ocupado pelos artistas? Qual a importância de se compartilhar sua música num formato digital e como isso é feito na maioria dos casos? Como se expressam as diferenças entre discos virtuais e discos físicos?

Qualquer discussão sobre processos de digitalização deve passar necessariamente por Pierre Lévy e seu livro "Cibercultura", publicado pela primeira vez em 1997. Nesse texto, o autor analisa conceitos importantes como: "Virtual”, "Digitalização da Informação", "Hipertexto", "Cibercultura" e "Ciberespaço". Ele já escrevia sobre algumas coisas que hoje invadem nosso cotidiano, como o compartilhamento de música digitalizada e a proliferação das redes sociais 
na internet. Para Lévy, "o crescimento do ciberespaço resulta de um movimento internacional de jovens ávidos para experimentar coletivamente formas de comunicação diferentes daquelas que as mídias clássicas nos propõem.” (LÉVY, 1999:11). Ele argumenta que estaríamos diante de um novo "universal" indeterminado, formado pela massa de informação proveniente dos mais diversos cantos do mundo, diferente de todas as formas culturais precedentes. A cibercultura é esse novo 'universal', virtual e indeterminado, que une as sociedades e grupos. Representa uma possibilidade de compartilhamento de informações e comunicação jamais vista na história da humanidade.

"O Ciberespaço (que também chamarei de "rede") é o novo meio de comunicação que surge da interconexão mundial de computadores. O termo especifica não apenas a infraestrutura material da comunicação digital, mas também o universo oceânico de informações que ela abriga, assim como os seres-humanos que navegam e alimentam esse universo. Quanto ao neologismo "cibercultura", especifica o conjunto de técnicas (materiais e intelectuais), de práticas, de atitudes, de modos de pensamento e de valores que se desenvolvem juntamente com o crescimento do ciberespaço." (LÉVY, Ibidem:17).

Os artistas com os quais trabalhamos nesta pesquisa fazem parte dessa geração de "jovens ávidos" para experimentação de novas práticas comunicacionais que o ciberespaço possibilita. São artistas que ocupam o ciberespaço de modo intenso, seja através de sites pessoais, de páginas no Myspace ou na atuação em redes sociais como Twitter e Facebook. Ao acompanhar sua atuação na internet podemos delinear importantes aspectos dessa cibercultura que Lévy menciona. Entretanto, a noção de cibercultura é mais antiga do que se imagina. Joon Ho Kim $(2004 ; 2005)$ nos lembra que a cibercultura está ligada à teoria cibernética que veio à tona nos anos 40 do século XX com os estudos do matemático Norbert Wierner. Segundo Kim, a cibernética foi deixada de lado pelos pensadores modernos ao longo da segunda metade do século XX, mas deixou resíduos que influenciam a ciência e a tecnologia até os dias atuais. Esses resíduos seriam constituídos por "noções e valores oriundos do discurso técnico científico" (KIM, 2004:205). Ainda segundo Kim, "um dos resíduos mais importantes que a cibernética legou à cibercultura foi a visão de que os seres vivos e as máquinas não são essencialmente diferentes." (KIM, Ibidem:206) A cibercultura é o espaço cibernético; a cibernética é a visão de que não existem descontinuidades entre humano e máquina, ambos engendram processamento de informações e controle semelhantes e sujeitos 
às mesmas leis matemáticas. Quem nunca ouviu a expressão ou ideia de que o corpo humano é uma máquina ${ }^{74}$ ?

\subsection{Digitalização da música}

A música gravada passou por diversos suportes e tecnologias ${ }^{75}$. O primeiro aparelho de gravação sonora foi o fonógrafo inventado por Thomas Edison em 1877. Os sons captados pelo fonógrafo eram armazenados de forma analógica ${ }^{76}$ num cilindro de cera que foi o primeiro tipo de suporte de arquivos sonoros. Em 1935, a empresa alemã I.G. Farben produziu uma fita magnética que seria precursora das gravações em fitas cassete. Em 1948, surgiram os discos de vinil, também chamados LPs (Long Plays) por possibilitarem o armazenamento de arquivos sonoros de duração mais longa. Esse suporte de vinil gerou um novo formato musical caracterizado pela possibilidade de reunir um número maior de músicas; formato chamado de álbum e que já explicamos em detalhes ao longo dos capítulos precedentes.

"De 1948 em diante, assistimos a uma sequência de inovações tecnológicas. O aparecimento do microssulco, além de promover um depuramento do processo de gravação e reprodução agora já elétrico, permitiu que o tempo de duração do disco fosse dilatado de quatro para trinta minutos, possibilitando ainda, no universo da música popular, a instituição da canção de três minutos como padrão.” (DIAS, 2008:41).

Até os vinis, os mecanismos de gravação e de armazenamento de sons eram totalmente analógicos. No ano de 1979, numa conferência para a imprensa, a Philips anunciou ao mundo o primeiro Compact Disc, primeiro dispositivo para armazenamento digital de música ${ }^{77}$. A cada novo suporte, há de se lembrar que uma nova série de aparelhos reprodutores é criada ou

\footnotetext{
${ }^{74}$ Interessante colocar que Kim $(2004 ; 2005)$ cita o autor Bruce Sterling para quem o ciberespaço começou com os humanos se comunicando por telefone e, portanto, teria mais de um século. Até ler este artigo de Kim eu pensava no ciberespaço como uma coisa totalmente contemporânea, uma novidade do final do século XX. Se concordarmos com os argumentos apresentados por Kim devemos reconhecer que a novidade é a intensificação do ciberespaço na vida cotidiana das sociedades cada vez mais interconectadas via internet. O termo ciberespaço teria aparecido pela primeira vez em 1982 na literatura cyberpunk no livro Neuromancer de Willian Gibson.

${ }^{75}$ Para uma apresentação mais detalhada dessas mudanças cf. Dias (2008).

${ }^{76} \mathrm{Na}$ tecnologia analógica de gravação, as ondas sonoras são captadas por membranas de microfones e são convertidas em vibrações físicas que passam diretamente para o suporte final que no caso do fonógrafo eram cilindros de cêra.

77 Extraído do site da BBC News: http://news.bbc.co.uk/2/hi/technology/6950933.stm, dia 02/04/2013, às 18:13 hrs.
} 
transformada para fornecer os produtos necessários para o usufruto musical dos consumidores. Assim vieram ao mundo os tocadores de fitas $\mathrm{K} 7$, as vitrolas, os walkmans, os $C D$ players, e finalmente os computadores pessoais e toda geração de aparelhos da era do MP3.

"Em 1987 o Institut Integrierte Schaltungen (ISS), na Alemanha, começou a trabalhar em uma codificação perceptual (um método que consiste em somente utilizar as frequências sonoras que são captadas pelo ouvido humano) para Transmissão Digital de Áudio (Digital Audio Broadcasting). O resultado do trabalho foi um algoritmo de compressão de áudio sem perda de qualidade, o MPEG Audio Layer-3, que ficou mundialmente conhecido como MP3." (Extraído do site: http://www.tecmundo.com.br/musica/214-o-que-e-mp3-.htm, dia 02/04/2013, às 19 hrs.)

A partir dos anos 90, já com a existência do MP3 e com o desenvolvimento da computação pessoal e da internet, os dados estavam lançados para as profundas transformações que abalariam os alicerces das grandes companhias fonográficas nos anos subsequentes. Um acontecimento marcante foi o surgimento do Napster, um programa de compartilhamento de arquivos em MP3, criado em 1999 por Shawn Fanning, um jovem americano com apenas 19 anos na época (que futuramente viria a ser uma das mentes responsáveis pela expansão do Facebook, rede social na internet criada por outro jovem americano, Mark Zuckerberg). O Napster foi o primeiro programa de compartilhamento que tomou proporções que incomodaram as grandes indústrias fonográficas ${ }^{78}$. Não é de se estranhar que o período em que mais se vendeu CDs físicos tenha sido em fins de 2000, próximo do surgimento do Napster. A partir de então, a venda de CDs físicos vem caindo acentuadamente e a indústria fonográfica vêm tentando se adequar ao compartilhamento digital de música. É o que se pode observar, por exemplo, segundo dados divulgados pela Associação Brasileira de Produtores de Disco (ABPD). No trecho abaixo, relata-se em 2003 uma queda nas vendas desde 2000, período em que a chamada pirataria digital começa a crescer.

"Segundo dados divulgados pela IFPI (Federação Internacional da Indústria Fonográfica), o mercado mundial de música no varejo indicou em 2003, pelo quarto ano consecutivo, queda nas vendas. No ano passado, registrou-se uma queda de 7,6\% em valores (U\$) e 6,5\% em unidades vendidas. Esse resultado é atribuído aos efeitos

\footnotetext{
${ }^{78}$ Em 2001, o Napster foi fechado devido a uma serie de ações legais de companhias da indústria fonográfica. Interessante que bandas e artistas se dividiram na época, a banda Metallica, por exemplo, se posicionou contra o site enquanto a banda Rage Against The Machine se posicionou a favor. Esse momento é importante para tudo que vem sendo discutido sobre direitos autorais, internet e pirataria durante esta primeira década do século XXI.
} 
combinados da pirataria digital e física e à concorrência proveniente de outros produtos para o entretenimento." (Trecho do Relatório do Mercado Brasileiro de Música 2003/2004, produzido pela Associação Brasileira de Produtores de Disco (ABPD), disponível

em: http://www.abpd.org.br/downloads/Mercado_Brasileiro_de_Musica_2003.pdf).

\begin{tabular}{|c|c|c|}
\hline ANO & Vendas Totais (R\$) & Unidades Totais \\
\hline 1999 & 814 milhöes & 88 milhöes \\
\hline 2000 & 890 milhões & 94 milhões \\
\hline 2001 & 677 milhões & 72 milhöes \\
\hline 2002 & 726 milhões & 74 milhões \\
\hline 2003 & 601 milhōes & 56 milhões \\
\hline Variaçäo (2002/2003) & $(-17 \%)$ & $(-25 \%)$ \\
\hline
\end{tabular}

Vendas de CDs, DVDs e VHSs musicais no Brasil. Fonte: Associação Brasileira de Produtores de Disco (ABPD).

A tabela acima extraída do mesmo relatório "Mercado Brasileiro de Música 2003", produzido pela Associação Brasileira de Produtores de Disco (ABPD), mostra a queda acentuada das vendas em valores monetários e em unidades vendidas somente para o Brasil. Notamos a virada negativa do mercado de 2000 para 2001, quando os números começam a cair. Ao longo do relatório nota-se uma queda geral em todo mundo ${ }^{79}$. Pesquisando os relatórios subsequentes publicados pela ABPD, do relatório de 2003 citado acima onde encontramos dados desde 1999, podemos observar queda contínua nas vendas físicas ${ }^{80}$, especialmente de CDs, até o ano de 2011 quando inesperadamente as vendas de unidades físicas no Brasil têm um leve aumento. Segundo a ABPD, esse aumento se deve ao bom desempenho da economia nesse período. As vendas digitais de música vêm aumentando no mundo todo de forma lenta, porém contínua. A tabela abaixo, extraída do relatório "Mercado Brasileiro de Música 2010", indica o aumento das vendas digitais no Brasil.

\footnotetext{
${ }^{79}$ Para maiores detalhes e informações sobre outros anos e sobre outros países, vale conferir o site da ABPD com vários relatórios e dados disponíveis para download: http://www.abpd.org.br/downloads.asp

${ }^{80}$ Com exceção dos anos de 2008 e 2009 que tiveram resultados positivos, toda primeira década do século XXI foi marcada pela queda na venda de CDs físicos.
} 


\section{TOTAL DAS VENDAS DIGITAIS NO BRASIL - ÚLTIMOS 5 ANOS}

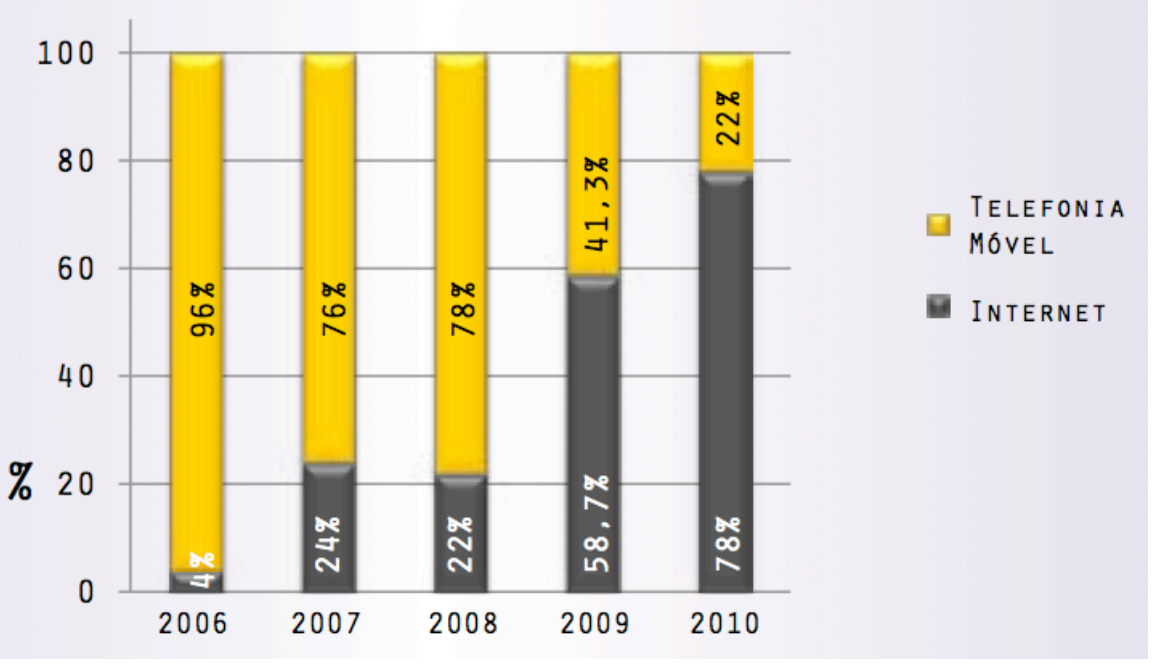

Vendas digitais no Brasil. Fonte: Associação Brasileira de Produtores de Disco (ABPD).

Com a internet e o surgimento de softwares que possibilitam o compartilhamento de arquivos de MP3, algumas bandas e artistas passaram a lançar discos puramente virtuais. A primeira a inovar nesse sentido foi a famosa banda de rock inglesa Radiohead, que lançou o álbum In Rainbows na internet em 2007 sendo que o preço cabia ao internauta determinar. No Brasil, Kiko Dinucci lançou o disco Metá-Metá somente pela internet e gratuitamente, no início de 2011. O disco físico só foi lançado no final do ano, num show na choperia do Sesc Pompéia, seis meses após o lançamento do disco virtual. Diversos sites da internet, como Facebook, Soundcloud e MySpace, permitem que qualquer um divulgue sua música. O Facebook se tornou tão importante para o mundo musical e artístico que existe uma configuração especial no site chamada "página de artista". Qualquer usuário pode criar sua página de artista, onde normalmente disponibiliza seus discos, fotos, agenda de shows etc. Hoje em dia, pode se afirmar que é prática rotineira disponibilizar os discos para download na internet.

Lévy (1999) e Kim (2005), entre outros, notam que o desenvolvimento dos computadores pessoais nasceu na Califórnia, na efervescência da contracultura dos anos 70. O aumento da performance desses computadores pessoais e a ampliação de seu uso foram pré-requisitos para o surgimento de uma cibercultura onde o compartilhamento de informações digitais se tornou comum. A digitalização está ligada ao que Lévy chama de virtualização. O virtual seria aquilo que existe em potência e não em ato. $\mathrm{O}$ virtual é o que ainda não se atualizou ${ }^{81}$.

\footnotetext{
${ }^{81}$ Vale notar aqui um comentário importante do colega Pedro Lolli em sua leitura prévia do texto. Ele me lembrou que o virtual foi analisado com profundidade por diversos filósofos e mereceria uma
} 
Um exemplo é a árvore que uma semente potencialmente contém. Essa árvore é virtual no sentido de que é uma possibilidade, não é atualizada enquanto a semente não for plantada e nutrida. A informação digital é uma tradução numérica, digitalizar significa traduzir em números. Toda informação digitalizada está virtualmente presente em todos os pontos do ciberespaço. Outro exemplo que Lévy menciona é o de uma foto de papel que quando digitalizada se torna uma série de números no disco rígido de um computador. Essa série numérica não é a "foto física", se torna uma descrição numérica que pode se materializar de inúmeras formas e em vários pontos da rede de computadores interconectados.

"Um som também pode ser digitalizado se for feita uma amostragem, ou seja, se forem tiradas medidas em intervalos regulares (mais de 60 mil vezes por segundo, a fim de capturar as altas frequências). Cada amostra pode ser codificada por um número que descreve o sinal sonoro no momento da medida. Qualquer sequência sonora ou musical pode ser, portanto, representável por uma lista de números.” (LÉVY, 1999:52).

Quando falamos em digitalização da música temos que levar em consideração a trajetória do $\mathrm{CD}$, que já trazia uma qualidade digital de áudio, até o MP3 que permitiu a ampla circulação de música na internet colocando em risco o CD físico. Temos que levar em conta também, a forma de produção da música propriamente dita. Novos programas de gravação digital de áudio $^{82}$ facilitaram muito a captação, a edição e a mixagem do material sonoro. Os equipamentos digitais de gravação se tornaram menores, mais simples e baratos ampliando o acesso dos músicos em geral ao disco. O próprio Lévy reflete sobre o caso da música na cibercultura e prenuncia o cenário que pudemos observar no nosso campo:

\begin{abstract}
"Assim como o fizeram em sua época a notação e a gravação, a digitalização instaura uma nova pragmática da criação e da audição musicais. Observei acima que o estúdio de gravação havia se tornado o principal instrumento, ou meta instrumento, da música contemporânea. Ora, um dos primeiros efeitos da digitalização foi o de colocar o estúdio ao alcance dos orçamentos individuais de qualquer músico." (LÉVY, Ibidem:143).
\end{abstract}

análise mais profunda que não teremos fôlego e nem espaço para realizar aqui. "Tanto a relação entre o virtual e o atual são reais. O virtual não para de se atualizar, assim como o atual não para de se virtualizar." (Pedro Lolli, comunicação pessoal). Esse comentário me alertou para para o perigo de tratar o virtual como oposto ao real.

${ }^{82}$ Os programas mais utilizados nos estúdios onde realizei trabalho de campo eram o Logic e o ProTools. Esses programas apresentam interfaces cada vez mais "amigáveis" para o usuário. Para uma discussão sobre as "interfaces amigáveis" cf Kim (2005). Ele demonstra como o desenvolvimento dos primeiros videogames foi fundamental para que os computadores se popularizassem, para que os códigos textuais de programação fossem substituídos por ícones gráficos de fácil manuseio. 
Podemos, partindo dessas considerações, pensar no disco como uma reunião de músicas gravadas que podem ser disponibilizadas de diversas maneiras: Vinil, CDs, Wave ${ }^{83}$ e/ou MP3. Os discos virtuais disponibilizados na internet estão virtualmente em qualquer ponto do ciberespaço e são atualizados a cada clique de download ou de play de um internauta. São descrições numéricas da massa sonora que jovens músicos captam com cada vez mais qualidade em seus estúdios e que podem se materializar de múltiplas formas em todo ciberespaço. Os sons digitalizados entram nesse oceano de informações que circulam instantaneamente pelo ciberespaço, essa velocidade e fluidez de circulação é uma característica marcante para os produtores de música de nossa época.

Dia 22 de maio, no Sesc Pinheiros em São Paulo, assisti a um show que celebrava o lançamento de uma plataforma digital de música, o Bagagem $^{84}$, criado por músicos para divulgarem, compartilharem e distribuírem música pela internet. Foi um importante evento que durou 4 dias com mesas de discussão, oficinas e shows onde a temática das novas tecnologias comunicacionais e musicais deu o tom. Kiko Dinucci participou do show final com seu trio, Metá-Metá, que havia acabado de lançar o disco virtual gratuitamente na internet com o apoio do pessoal que criou o Bagagem. Numa rápida entrevista por telefone antes do show, Kiko me afirmara:

"É fantástico botar o disco na internet de graça. Nos primeiros dias, 2.700 pessoas baixaram o Bagagem e provavelmente baixaram meu disco... Não me interessa vender disco, me interessa as pessoas cantando minhas músicas no show."

Felipe Julian da banda Axial e um dos criadores da plataforma, no final do show explicou:

"A cultura é para ser compartilhada, nós queremos compartilhar música e o Bagagem foi uma forma que encontramos de compartilhar."

\footnotetext{
${ }^{83}$ Wave é, ao lado do MP3, um outro tipo de formato de arquivo digital de áudio. Os arquivos em Wave são uma pouco mais pesados do que o MP3, ou seja, ocupam mais espaço nas memórias de computador e demoram mais para serem baixados ou compartilhados, justamente por apresentarem uma qualidade sonora maior.

${ }^{84}$ Trata-se de um software novo para baixar e compartilhar música na internet criado por músicos paulistanos, em especial, Felipe Julian da banda Axial.
} 
Interessante essa fala porque revela uma noção otimista e amplamente divulgada sobre os benefícios do mundo online; a visão de que a internet é o espaço privilegiado para compartilhamento de informações e de bens culturais. O discurso de Kiko vai ao encontro dessa visão otimista - para o artista é bom compartilhar a música porque em troca ele aumenta seu público. No caso desses conteúdos musicais, torna-se mais importante compartilhar do que vender. O dinheiro vem de outras formas, Felipe Julian por exemplo, dá aulas de produção musical. Kiko, compartilhando seus discos, ganha popularidade e consegue fechar mais contratos de show. Esse compartilhamento de conteúdos digitais pode ser visto como uma troca, ao menos no caso da música. O compositor troca seu disco virtual pelo reconhecimento de seu trabalho. Disponibilizar o disco na internet gratuitamente, no caso do Metá-Metá, gerou uma resposta dos ouvintes. Quando o disco físico foi lançado seis meses depois no Sesc Pompéia, o show estava lotado e o público já sabia cantar todas as músicas. A música é a dádiva trocada; o compositor doa essa dádiva em forma disco e a recebe de volta com o público lotando e cantando nas performances ao vivo. Com esse feedback ele se vê motivado a gravar o próximo disco, reiniciando um ciclo produtivo de novas composições. Numa entrevista publicada no livro Cultura Digital.br, Eduardo Viveiros de Castro fala sobre uma grande diferença entre a forma como os ocidentais e os indígenas da América lidam com as transações em geral. Ele comenta, em relação à troca de objetos, que:

“[...] o problema deles não é o objeto, o que eles querem é a relação. Uma vez a relação se mantendo, o objeto cumpriu sua função. Essa é a ideia da relação como algo interminável: a dádiva. Toda dádiva é interminável, é uma relação interminável. Toda dádiva produz uma dívida, e essa relação da dádiva com a dívida é uma relação propriamente interminável." (SAVAZONI; COHN, 2009:88).

No caso dos discos disponibilizados gratuitamente na internet os músicos esperam construir uma relação com seu público, algumas vezes até mesmo construir um público que ainda não existe. $\mathrm{O}$ disco importa na medida em que consolida essa relação entre artista e público fechando as pontas do triângulo autor-obra-público já mencionado por Cândido ([1965] 2006). A digitalização da música fornece aos artistas como Kiko Dinucci uma forma de estabelecerem e manterem relação com um público amplo de ouvintes. Essa relação é marcada pela facilidade de comunicação, a grande revolução é a realização dessa comunicação de conteúdos sem intermediários. 
Tatá Aeroplano também é totalmente a favor da disponibilização gratuita de seu disco na internet. Ele conta, inclusive, que sua saída do selo PHONOBASE, que havia lançado os dois últimos discos do Cérebro Eletrônico, se deu em parte devido ao fato de Juliano Polimeno, dono do selo, ser contra a disponibilização gratuita. Juliano Polimeno acabou fechando oficialmente a PHONOBASE em 2012, e passou a trabalhar na plataforma "ONErpm" especializada no comércio digital de música. Ele se mostra um fervoroso propagandista da ideia de que os músicos devem vender suas músicas online e de que o download gratuito prejudica o artista. Entretanto, em 2011 numa entrevista que me concedeu, seu discurso caiu em contradição com essa postura. Ele menciona na entrevista uma pesquisa nos Estados Unidos que mostrava quantos downloads pagos um artista precisaria ter para ganhar um salário mínimo americano que na época estava em torno de 1.200 dólares.

"Nos EUA, o salário mínimo americano é 1.200 dólares, os caras fizeram um estudo nessas várias formatações de música de quanto o artista precisava vender ou tocar para atingir esses 1.200 dólares por mês. Se ele vende um disco diretamente no show por 15 dólares, ele tem que vender uns 150 discos por mês. Eles mostram essa história do "spotfy", por exemplo, como funciona o pagamento para o artista. O artista só recebe se você, enquanto público, toca ele. Num catálogo de 5 milhões de músicas, se o cara não dá uma busca no Rodrigo Campos e dá um play nele, o artista não recebe. O artista só recebe quando o público aperta o play... e aí você tem que ter 4 milhões de plays pra chegar nos 1.200 dólares por mês.” (Entrevista com Juliano Polimeno, dia 17/05/2011).

Na sequência da entrevista, Juliano Polimeno me confidenciava que a renda dos artistas da PHONOBASE vinha através de shows. Ele se dizia em crise justamente pela empresa, cujo foco inicial era buscar iniciativas novas na conexão entre público e artistas através da internet, ter se tornado mais uma empresa de venda de shows. Até aquele momento, a internet não havia possibilitado que a PHONOBASE se sustentasse com vendas de fonogramas online. Tatá Aeroplano lançou seu disco solo fora da PHONOBASE, o selo se tornara um intermediário perfeitamente dispensável na medida em que o artista fortalecia sua autonomia em grande parte devido ao alcance de seu disco disponibilizado gratuitamente na internet e na sua crescente formação de público através dessa divulgação online.

\footnotetext{
${ }^{85}$ Para conhecer melhor esta empresa de venda de música online baste entrar em: https://onerpm.com/.
} 


\subsection{Sociedade em rede e comunicação}

Num artigo de 2002, The Anthropology of Online, Samuel M. Wilson e Leighton C. Peterson fazem uma breve e interessante revisão do que a antropologia havia produzido, até então, no que diz respeito às novas tecnologias de comunicação emergentes, à internet e ao mundo virtual do ciberespaço. Sendo um fenômeno recente, era de se esperar que não houvessem grandes estudos e teorias antropológicas desse mundo online que crescia (e cresce) acentuadamente no início desse nosso século XXI. "A conclusão geral é de que as tecnologias constituintes da internet, e todos os textos e meios de comunicação que existem em seu interior são, em si mesmos, produtos culturais." (WILSON e PETERSON, 2002:449). Sendo assim, a antropologia seria uma disciplina importante para se avançar na compreensão da internet e das "comunidades online". As comunidades online seriam grupos baseados na internet ${ }^{86}$.

Segundo a rápida revisão das discussões teóricas que estes autores fazem no artigo, existiam, ao final do século $\mathrm{XX}$, duas visões gerais sobre as transformações que a internet promovia, uma otimista e uma pessimista. Para os otimistas, as novas práticas comunicacionais que se formavam online aumentariam o poder político dos cidadãos. A internet seria a democracia perfeita dos pós-modernos, onde todos podem divulgar suas ideias, tanto grupos e instituições quanto indivíduos. Essa visão caminha em concordância ao que a maioria dos artistas do meio musical que estudei afirmam. Todos consideram a internet uma coisa boa e que auxilia seus trabalhos. Pela visão pessimista, a internet promoveria uma aumento da alienação, do isolamento e de comportamentos antissociais no mundo pós-moderno (WILSON; PETERSON, 2002 e CASTELLS, 2005). Sem falar que os Estados aumentariam seu controle sobre as práticas comunicacionais online. No caso da música, as grandes companhias fonográficas entraram numa crise sem precedentes em todo mundo revelando uma outra faceta das influências da internet.

Uma mescla das duas visões é interessante para se avaliar como a internet afeta as práticas comunicacionais, os comportamentos humanos e as possibilidades de cada usuário em se beneficiar ou não de suas potencialidades intrínsecas, ou seja, reconhecer que tudo está em

\footnotetext{
${ }^{86}$ Lévy fala em comunidades virtuais para se referir às comunidades online. "Comunidade virtual é um grupo de pessoas se correspondendo mutuamente por meio de computadores interconectados." (LÉVY, 1999:27).
} 
aberto no ciberespaço, nada é absoluto, o caráter positivo ou não de seus usos vai variar de acordo com cada situação. Outra questão importante no estudo das comunidades online é a rapidez das transformações. Wilson e Peterson (2002) falam na efemeridade desse campo. Tudo muda muito rápido - tecnologias, interfaces, softwares, aplicativos, laptops etc. Entretanto, eles localizam alguns elementos que persistiriam mesmo com as transformações rápidas em curso. Eles falam em categorias de comunicação para se pensar nas interações online.

\begin{abstract}
"Independentemente de mídias particulares, interfaces, ou aplicações - que vão continuar mudando nos próximos anos - categorias gerais de comunicação vão persistir, incluindo uma-pessoa-para-uma (como numa mensagem de e-mail), uma-para-muitas (como na publicação de uma página na Web) e muitas-para-muitas (participando de um fórum de discussão). Essas categorias de comunicação requerem que prestemos atenção na natureza das práticas comunicativas e nas interações online. As tecnologias de comunicação que fazem uso da infraestrutura da internet compartilham algumas características especiais. Desse modo, elas oferecem possibilidades e restrições especiais a práticas comunicativas e interações sociais e fornecem um contexto para formas de comunicação emergentes." (WILSON; PETERSON, 2002:453)
\end{abstract}

Os estudos em comunicação são mais numerosos quando se trata de internet, cibercultura, ciberespaço e as novas tecnologias envolvidas. A internet e a digitalização da informação operam grandes transformações técnicas e sociais, e talvez a maior dessa transformações seja, justamente, no modo como nos comunicamos uns com os outros. Comunicação à distância, chats de discussão, e-mails, sites são algumas das novas experiências comunicacionais que a internet trouxe. "Essa comunicação, mais do que permitir aos indivíduos comunicar-se, amplificou a capacidade de conexão, permitindo que redes fossem criadas ou expressas nesses espaços: as redes sociais mediadas pelo computador." (RECUERO, 2010:16). Nessas redes, dois elementos são fundamentais: atores (pessoas, instituições, grupos) e conexões (laços sociais estabelecidos entre esses atores). Segundo Raquel Recuero (2010), são esses os dois termos mais utilizados na área da comunicação para o estudo das redes sociais na internet. Os atores são representados graficamente por nós e os as conexões por arestas que conectam os nós. Diversos nós e arestas compõem um grafo.

No estudo das redes sociais, podemos formar diferentes tipos de grafos conforme o grau de conexão e número de atores envolvidos. Um ator pode ser um blog, um site ou um perfil de Facebook. Ainda existe a possibilidade de uma dessas ferramentas representar um grupo de atores. Recuero (Ibidem) cita alguns autores que discutem como os atores trabalham uma 
construção de si na internet através dessas ferramentas online. Os artistas que se apropriam dessas ferramentas para divulgação de seus discos, também efetivam uma construção de imagens públicas de si mesmos.

"Essas apropriações funcionam como uma presença do "eu" no ciberespaço, um espaço privado e, ao mesmo tempo, público. Essa individualização dessa expressão, de alguém "que fala" através desse espaço é que permite que as redes sociais sejam expressas na internet." (RECUERO, 2010:27).

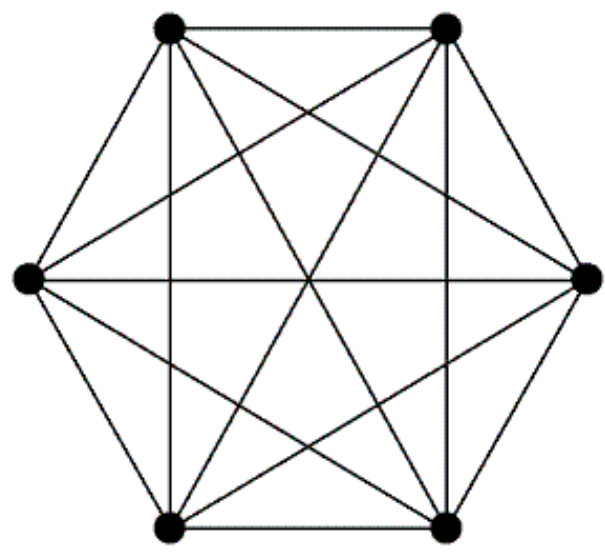

Representação de um grafo onde os pontos são os nós (atores), e as linhas são as arestas (conexões)

As conexões entre artistas e seu público, por exemplo, podem ser pensadas como laços sociais que se fortalecem e/ou se estabelecem no ciberespaço a partir dessas ferramentas comunicacionais. Esses laços sociais são mantidos e estabelecidos a cada interação entre artista e outro ator da rede. Um exemplo são os espaços para comentários que o Youtube possui. $\mathrm{O}$ artista que abre um canal no Youtube para postar seus clipes e vídeos verá com o tempo uma série de comentários sendo feitos abaixo de cada vídeo. Ele pode responder individualmente a cada comentário. Em sua página no Facebook, o artista pode estabelecer diversos tipos de interação online com seu público. Um exemplo interessante são os comentários de fãs na página do Facebook do Kiko Dinucci dia 17 de Dezembro de 2012, um dia depois do lançamento do 2o disco do Metá- Metá, o Metal Metal:

\section{Fã 1}

"O show estava uma loucura! Eu estava com uma gripe lascada, com febre, mas não aguentei e comecei a dançar. Saí de lá muito melhor tamanha a energia vibrante e maravilhosa das intensas interpretações da Juçara, das composições e da guitarra 
enfezada do Kiko, do baixo louco do Marcelo, da bateria maravilhosa do Sérgio, da percussão divina do Samba Sam, e mais que tudo pelo doido maluco e maravilhoso Thiago com os sopros. Ele estava que era puro brilho!!! Aliás todos!!!

Vocês me deram um presente de fim de ano!!!

Vocês são meus Beatles, meus Stones!!! Fã absoluta!!!”

\section{Fã 2}

“Chegando do show maravilhoso hoje do Metal Metal Metá Metá

que bom poder estar lá

coisa mais genial que o mundo precisa ouvir...dançar...agradecer

foi apenas o começo de tudo de bom que virá

parabéns meus queridos Juçara Marçal, Kiko Dinucci e todos que brilharam naquele palco do Sesc Vila Mariana, estou aplaudindo até agora!!!”

\section{Fã 3}

"E o que se diz depois de um show como esse? "obrigada?" não sei o que dizer não sei o que fazer não sei o que pensar só sei que tô sentindo uns lances muito loucos. Vocês acabaram comigo. Por hora fiquem com meu obrigada por todo este arrebate, seus cabras safados e safadas!"

\section{Fã 4}

"Metal Metal no osso no couro no dna afropunkandomblé (adorei e adotei Ivany Turibio), potência máxima da música kusturica na veia brasil total metal metalfísico catártico meio épico, saí de lá com vontade de correr subir montanha e gritar! (pro Kiko Dinucci Juçara Marçal Thiago França)"

A internet que consolida uma "sociedade em rede" (CASTELLS, 2005) permite essa interação direta entre um artista e seu público. Apenas um dia após o show, Kiko Dinucci e seus companheiros do Metá-Metá tem a possibilidade de se conectarem com os fãs que compareceram no show e que manifestam essas mensagens de apoio, agradecimento e aprovação. O disco virtual da banda pode ser facilmente baixado no site de Kiko como eu mesmo fiz no dia seguinte ao show. Situações como essa reforçam a ideia de que não vale a pena pensar em dois mundos isolados, um virtual (digital) e outro real (físico). Nesse exemplo, as interações online reforçaram as interações offline; uma não substitui a outra, elas 
se reforçam e se complementam ${ }^{87}$. Compartilho da visão de Wilson e Peterson (2002) de que "a distinção entre comunidade real e imaginada ou comunidade virtual não é útil, e a abordagem antropológica está bem situada para investigar o contínuo de comunidades, identidades e redes que existem." (WILSON e PETERSON, 2002:456-457). Indo mais longe, se a etnografia é o método tradicional de antropologia baseado desde seus primórdios na observação participante, como realizar uma etnografia de grupos que participam intensamente do ciberespaço sem imergir nesse ambiente? Para Christine Hine (2000), a etnografia virtual é a extensão da etnografia tradicional para os ambientes online onde nossos interlocutores atuam, agem, escrevem, publicam ideias e estão sujeitos a toda uma gama de experiências sociais. A própria experiência de estar conectado a uma rede social é fundamental enquanto método de pesquisa.

\begin{abstract}
"A interação face à face e a retórica de ter viajado a um campo remoto, tem ocupado um papel central na representação das descrições etnográficas como autênticas. Um meio limitado como a CMC (Comunicação Mediada por Computador) parece colocar um problema para as reivindicações da etnografia de testar o conhecimento através da experiência e da interação. A posição muda um pouco se reconhecermos como alternativa que o etnógrafo pode ser construído como necessitando ter experiências similares as dos informantes, embora sejam experiências mediadas. Conduzir uma pesquisa etnográfica através do uso da CMC abre a possibilidade de obter um entendimento reflexivo do que seja fazer parte da internet." (HINE, 2000:10).
\end{abstract}

$\mathrm{O}$ grupo sonoro investigado aqui está totalmente imerso nesse ambiente virtual da internet. $\mathrm{O}$ ponto que Hine levanta é que para uma compreensão reflexiva sobre esse grupo, o investigador deve participar também desse universo digital, desse ciberespaço ou dessa “sociedade em rede.” O sociólogo espanhol Manuel Castells (2005) trabalha com a expressão "sociedade em rede" (network society) para analisar as transformações nas práticas comunicacionais que essas novas tecnologias operam. Interessante que o autor reconhece que as redes são formas de organização social antigas. A novidade são as novas capacidades formadas a partir de redes baseadas em tecnologias microeletrônicas. Da mesma forma, o contato entre um artista e seu público é algo anterior à internet, porém as possibilidades e formas se amplificam nessa interação via redes sociais online.

"A sociedade em rede, em termos simplificados, é uma estrutura social baseada em redes operadas por tecnologias de informação e comunicação baseadas em redes digitais

\footnotetext{
${ }^{87}$ Para um crítica sobre a dicotomia online-offline que se amplifica numa crítica às dicotomias sujeitoobjeto e sociedade-técnica nos estudos antropológicos da cibercultura cf. Rifiotis (2012).
} 
e microeletrônicas de computadores que geram, processam e distribuem informação na base do conhecimento acumulado nos nós das redes." (CASTELLS, 2005:7).

Castells discute algumas importantes transformações econômicas e políticas que a interconexão global de computadores gera. Fala por exemplo, que o perfil de carreira mudou. Os empregos estáveis e duradouros estão sendo substituídos por profissões autônomas e mais dinâmicas. $\mathrm{O}$ perfil do trabalhador está mudando. O profissional da sociedade em rede deseja autonomia e liberdade abdicando muitas vezes de maior estabilidade e sucesso financeiro. Trazendo essa discussão para a área da música, observamos que os artistas estão cada vez mais autônomos em relação às gravadoras. Tatá Aeroplano afirma que "o que importa é a canção e eu não preciso mais do esquema das gravadoras.” Esse tipo de discurso nativo é o reflexo - numa esfera micro social, biográfica - das transformações econômicas que uma sociedade estruturada em redes de computadores conectados experimenta. Essa autonomia se espalha em diversas atividades profissionais promovendo o que Castells chama de "descentralização de serviços e funções" e de "trabalho auto-programável (self-programmable labor)." Essa ideia de trabalho auto-programável se enquadra adequadamente no que observamos junto aos artistas do mundo musical. Os artistas gravam seus discos autonomamente e os disponibilizam gratuitamente na internet "não para aumentar os ganhos financeiros, necessariamente, mas para obter mais liberdade, flexibilidade de tempo, ou mais oportunidades para criar.”(CASTELLS, Ibidem:10). A mídia de massa que caracterizou a sociedade industrial convive agora com uma comunicação socializada no ciberespaço. Castells traça sempre um contraponto com o que chama de sociedade industrial ao caracterizar o que seria a sociedade em rede.

Inseridos dentro desses ciberespaços e participando ativamente dessas redes sociais, Kiko Dinucci, Tatá Aeroplano e Rodrigo Campos conseguem divulgar seus discos e entrar em contato com seus fãs e com seu público. Os meios de comunicação de massa como TV e rádio não são mais as únicas formas de conectar artistas e público, apesar de seu alcance ainda ser bem maior. Veremos a seguir, através de uma etnografia virtual (uma imersão nas redes sociais onde esse grupo atua como nos sugere Hine (2000)) como eles ocupam o ciberespaço analisando os seguintes dados: suas páginas no MySpace, seus sites pessoais, suas páginas no Soundcloud e no Facebook. Procuraremos descrever a forma como seus discos chegam e atuam na rede. 


\subsection{O uso do MySpace}

Entre 2007 e 2009, o site MySpace se tornou bastante popular no Brasil, especialmente entre músicos. O MySpace é uma rede social da internet onde se pode disponibilizar no ciberespaço diversas informações como músicas, fotos, textos e vídeos. Justamente por permitir que o administrador de uma página faça uploads de músicas, o MySpace se tornou bastante popular entre músicos. Diversos artistas começaram a lançar via MySpace suas páginas contendo músicas, releases, fotos e agenda de shows. Ao entrar na rede do MySpace cada um entra numa rede de milhões de pessoas interconectadas que também possuem suas próprias páginas. Você pode convidar e/ou ser convidado a se tornar amigo de outras pessoas. O site caminhou bem até 2009, ano em que o Facebook desbancou o MySpace americano. Mesmo ainda sendo popular no Brasil em 2009 o MySpace fechou seu escritório no país ${ }^{88}$.

Entre os artistas, gradualmente o MySpace foi se tornando menos usado. Kiko Dinucci e Tatá Aeroplano ainda possuem suas páginas no MySpace mas não as divulgam nem as atualizam. Ainda assim, ao digitar o nome dos artistas no Google, por exemplo, seus endereços no MySpace aparecem entre os primeiros links da pesquisa. Rodrigo Campos não possui uma página no MySpace. Ao digitar o nome de Rodrigo Campos no Google acontece uma certa confusão, porque existe um DJ relativamente conhecido que também se chama Rodrigo Campos. Para encontrar as páginas ligadas ao Rodrigo Campos que é nosso interlocutor aqui, é necessária uma busca mais específica, aí então, encontramos os links do ciberespaço onde Rodrigo e sua música estão.

O MySpace de Kiko Dinucci ${ }^{89}$ tem um fundo num tom bege com detalhes em marrom, no canto superior esquerdo uma foto da cara de Kiko e uma série de janelas para se acessar os conteúdos da página.

\footnotetext{
${ }^{88}$ Para mais detalhes ver matéria publicada pela Folha Online dia 22/06/2009 no endereço: http://www1.folha.uol.com.br/folha/informatica/ult124u584866.shtml

${ }^{89}$ https://www.myspace.com/kikodinucci
} 


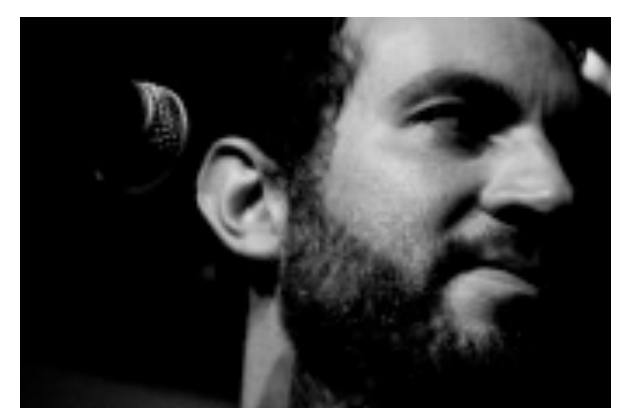

Foto de Kiko Dinucci no Myspace

Ao clicar na janela "músicas" encontramos dez composições do artistas na seguinte ordem: “Ciranda Para Janaína, Zé Pelintrowski, Depressão Periférica, São Jorge, Forró do Homem Bomba, Funeral, Dejá Vu, Beijo da Iara, Mosquitinho de Velório, Mãe da Vertigem." A única das dez faixas apresentadas na página que não foi lançada também em discos físicos é "Zé Pelintrowski." Abaixo do título de cada música, o Myspace indica quantas reproduções foram feitas, uma informação importante para o artista acompanhar seu alcance. Observando os números percebi que a ordem das músicas na página foi estabelecida pelo número de reproduções de cada música. "Ciranda Para Janaína”, em primeiro, tinha 3.419 reproduções e “Mãe da Vertigem”, em último, tinha 790 reproduções na última vez que entrei na página, dia 21/05/2013. Ao lado de cada música, existem três ícones: um sinal de mais $(+)$ para o visitante adicionar a música a uma lista de reprodução, uma seta curvada para o visitante compartilhar a música em outras redes sociais e uma seta reta para baixo escrito "buy" ao lado, que no caso de Kiko estava desativada. Estas são formas através das quais qualquer visitante da página pode interagir com as músicas do artistas. Além disso, existe uma janela que possibilita comentários, mas só de quem está inscrito no site. Kiko Dinucci possuía, até dia 21/05/2013, 1.246 amigos dentro do MySpace, ou seja, ele estava diretamente conectado a 1.246 pessoas que também possuem perfis no site. Na página, ainda encontramos as seguintes informações:

\section{"Gênero: Alternativa / Experimental}

Local Guarulhos, São Paulo, BR

Exibições de Perfil: 52859

Último Login: 06/03/2011

Membro Desde 13/07/2009

Site www.desmonta.com

Tipo de Selo Indie" 
Chama a atenção o fato de Kiko não fazer login desde Março de 2011. Fazer login significa acessar sua página e no caso de Kiko, faz aproximadamente dois anos que ele não a acessa. Outra informação importante é o número de exibições de perfil, 52.859 visitaram o MySpace de Kiko desde que ele se tornou membro em 13/07/2009.

Ao entrar no MySpace de Tatá Aeroplano, encontramos o mesmo tipo de informação. No canto superior esquerdo, uma foto do artista publicada na horizontal exatamente como segue aqui:

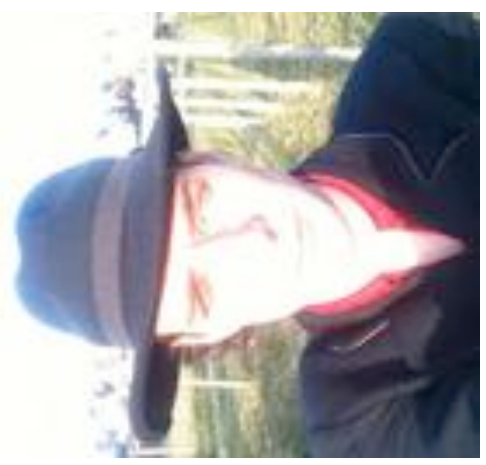

"Gênero: Alternativa / Pop / Psicodélico

Local São Paulo, São Paulo, Br

Exibições de Perfil: 52975

Último Login: 11/08/2012

Membro Desde 05/10/2007

Site

http://www.msplinks.com/MDFodHRwOi8vd3d3LnRhdGFhZXJvcGxhbm8uY29tLmJy

Selo de Gravação Voador Discos

Tipo de Selo Não-assinado"

Vemos que Tatá é membro há mais tempo que Kiko e que continuou utilizando o site por mais tempo; seu último login foi em Agosto de 2012. Um dado que me chamou a atenção imediatamente foi o número de exibições bem próximo entre os dois artistas. Tatá conta com 52.975 exibições. Entretanto, na página de Tatá no MySpace não encontramos nenhuma música. Sob um fundo branco e cinza encontramos apenas um link para download do disco, além de fotos, vídeos e comentários. Tatá utiliza o MySpace para divulgar o link do disco, ao 
invés de colocar as canções direto na página. É um outro tipo de estratégia de uso, diferente do que a maioria dos artistas que utilizam este site fazem. Observando o espaço dos comentários no MySpace de Tatá vemos que os artistas utilizam o site para se comunicarem entre si e divulgarem shows e discos. As cantoras Juliana R. e Arícia Mess postaram os seguintes comentários para Tatá:

“Tatá, querido, apareça sexta no lançamento de meu $1^{\circ}$ disco! Sexta, 19 de novembro, às 22h00 Centro Cultural Rio Verde - (11) 3469-5321 Rua Belmiro Braga, 181 - Villa Madalena, SP R\$ 15"

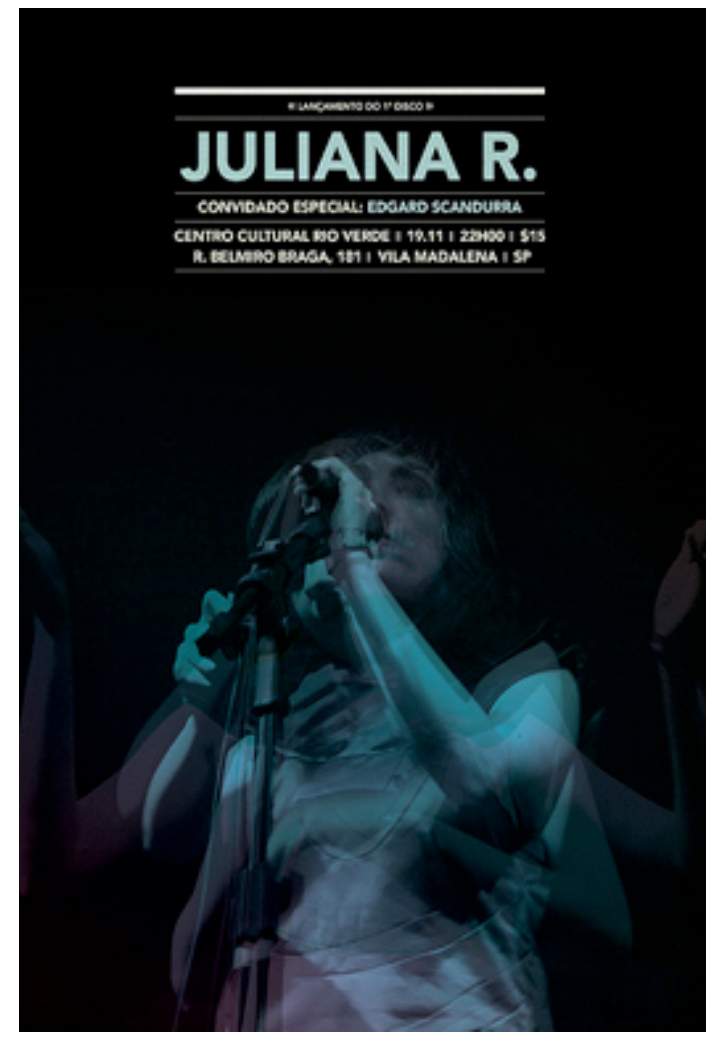

(Comentário de Juliana R. no Myspace de Tatá Aeroplano)

“Ola Tatá Aeroplano,

Convido voce para a audição virtual do meu novo CD "Onde Mora o Segredo". As músicas ficarão no ar por apenas $72 \mathrm{hs}$.

Espero sua visita www.myspace.com/ondemoraosegredo

Inicio: dia 19 de novembro, sexta-feira as 14:00 horas

Termino: dia 22 de novembro, segunda-feira as 14:00 horas

Até mais,

Arícia Mess" (Comentário de Arícia Mess no Myspace de Tatá Aeroplano) 
Apesar de manter sua página do MySpace no ar, Tatá me afirmou que hoje em dia concentra suas atividades online no seu site, complementando com o uso do Facebook e do Instagram. Me contou também que o Soundcloud, site especial para postar músicas, cortou seu link questionando a autoria de suas músicas em Abril de 2013. O episódio serviu para o artista reafirmar sua autonomia e reforçar a importância do seu site para a divulgação de sua obra. Eu perguntei se ele iria recorrer à decisão do Soundcloud e ele me respondeu:

“Eu não preciso perder tempo com isso, agora vou deixar minhas músicas só no meu site. Vai ser até melhor porque as pessoas vão lá digitar meu nome no Google e caem direto no site. Eu não preciso do Soundcloud." (Entrevista com Tatá Aeroplano, dia 24/05/2013).

Esse tipo de discurso reforça a autonomia que as ferramentas comunicacionais da sociedade em rede propiciam aos artistas. Mesmo uma grande empresa da internet como o Souncloud não é mais imprescindível para um artista como Tatá Aeroplano. Castells (2005) reconhece esse tipo de possibilidade que a sociedade em rede gera. A atuação online de Tatá Aeroplano com seu site poderia se enquadrar no que Castells chama de "comunicação de massa autodirigida."

\begin{abstract}
"Enquanto a sociedade em rede se difunde e novas tecnologias de comunicação expandem suas redes, há uma explosão de redes horizontais de comunicação, bastante independentes dos governos e das grandes mídias, que permitem a emergência do que chamo comunicação de massa auto-dirigida (self-directed mass communication). É comunicação de massa porque se difunde pela internet, portanto potencialmente atinge todo planeta. É auto-dirigida porque frequentemente é iniciada pelos próprios indivíduos ou grupos, atravessando o sistema de mídia. A explosão de blogs, vlogs, podding, streaming, e outras formas de interação, a comunicação de computador para computador criam um novo sistema de comunicação horizontal e global em rede que, pela primeira vez na história. permite às pessoas se comunicarem entre si sem passarem pelos canais forjados pelas instituições da sociedade para comunicação socializada." (CASTELLS, 2005:13).
\end{abstract}

Os artistas com seus sites, suas páginas e blogs atuam dessa forma transpassando os meios de comunicação tradicionais - TV, Rádio e até grandes sites - na divulgação de sua música.

"Isso pode acontecer agora porque a Internet $2.0^{90}$ faz com que seja mais fácil para pessoas comuns se organizarem, em vez de terem de fazer isso sob o controle de

\footnotetext{
${ }^{90}$ Segundo Don Tapscott (2010), empresário entusiasta da internet que já publicou alguns livros sobre as características das gerações mais jovens imersas no mundo digital, a internet 2.0 é baseada na
} 
organizações hierárquicas e muitas vezes autoritárias. Em vez de serem apenas pequenas engrenagens em uma máquina grande e impessoal, essas pessoas agora podem descobrir o poder para se tornarem entidades autônomas." (TAPSCOTT, 2010: 54, grifo meu).

Esse caso peculiar de Tatá Aeroplano com o Soundcloud revela ainda um momento posterior ao que esses autores observam, um momento em que algumas empresas da própria internet se tornam grandes corporações hierarquizadas, mas que podem ser dispensadas quando um ator individual é capaz de utilizar estrategicamente seu site para atingir seus objetivos.

\subsection{O uso do Soundcloud}

Rodrigo Campos não chegou a ter uma página sua no MySpace e também não possui um site individual como Kiko Dinucci e Tatá Aeroplano. Sua atuação online se baseia no Facebook e no Soundcloud. A tradução literal de Soundcloud para o português seria algo como "Nuvem Sonora". A expressão nuvem é bastante utilizada como metáfora do ciberespaço e da circulação vertiginosa de informações que nele acontece. Tanto as nuvens quanto o ciberespaço são dinâmicos, suas formas estão em constante mutação. O Soundcloud é uma plataforma online para publicação de arquivos de áudio. Foi fundado na Alemanha em 2007 por Alexander Ljung e Eric Wahlforrs para que músicos pudessem discutir e publicar suas composições antes de um lançamento oficial. Com o tempo passou a ser apropriada, pelos internautas em geral, para publicação de músicas.

Rodrigo Campos possui um perfil no Soundcloud onde estão as composições de seus dois discos, São Mateus Não é Um Lugar Assim Tão Longe e Bahia Fantástica. Um diferencial do Soundcloud é que ele apresenta os espectros de áudio de cada música em widgets $^{91}$ onde também existem botões e janelas onde o internauta que visita a página pode compartilhar cada composição. Cada widget pode ser embutido em outras páginas, ou seja, se o artista tem um site ele pode embutir o widget de cada canção que publicou no Soundcloud no seu site. Assim como o Myspace, o Soundcloud informa o número de reproduções que cada música teve. Rodrigo teve 6.281 reproduções da canção "Cinco Doces” do Bahia Fantástica (a faixa com maior número) e 367 reproduções da canção "Fim da Cidade" do disco São Mateus Não é Um

interatividade enquanto a internet primitiva era baseada no acesso à conteúdos. "A internet atual se baseia em algo chamado XML. Mais do que um padrão de linguagem para apresentar conteúdo, tratase de um padrão de programabilidade - chame-a de "internet programável"." (TAPSCOTT, 2010:29).

${ }^{91}$ Widgets são componentes de interfaces que incluem botões, ícones, janelas etc. 
Lugar Assim Tão Longe (faixa com o menor número). A maioria das faixas publicadas já teve mais de 1.000 reproduções o que revela uma boa popularidade da página de Rodrigo Campos. Ele tinha, até a data da nossa última consulta dia 04 de Junho de 2013, 708 seguidores (followers) e seguia 230 perfis do site.

O fato de permitir que cada widget publicado seja compartilhado e embutido em outros sites, faz com que o Soundcloud seja bastante utilizado pelos artistas, pelas pessoas que os admiram e que trabalham com eles. Antes de lançar o Bahia Fantástica no dia 31 de Maio de 2012, diversas pessoas divulgavam o disco pelo Soundcloud no Facebook. Dessa forma, o disco devidamente digitalizado se espalha na rede antes do lançamento físico acontecer. Qualquer um pode se tornar divulgador do disco Bahia Fantástica se entrar o Soundcloud e compartilhar o widget do disco.

Até dia 04 de Junho de 2013, Kiko Dinucci havia publicado 33 faixas no seu Soundcloud, sendo que a faixa com mais reproduções era "Luzia, Rainha do Baianá - Alessandra Leão Remix", com 1.951, e a faixa "João Carranca" era a que aparecia com menos, 279 reproduções. Kiko estava com 1.026 seguidores e seguindo 87. As faixas misturavam o repertório dos diversos discos que lançou com seus parceiros ao longo do tempo.

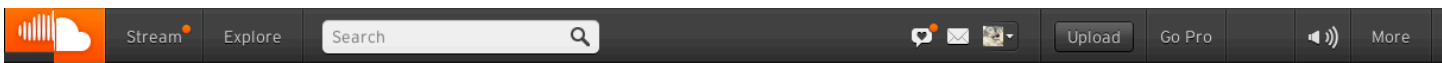

Rodrigo Campos - Bahia Fantástica

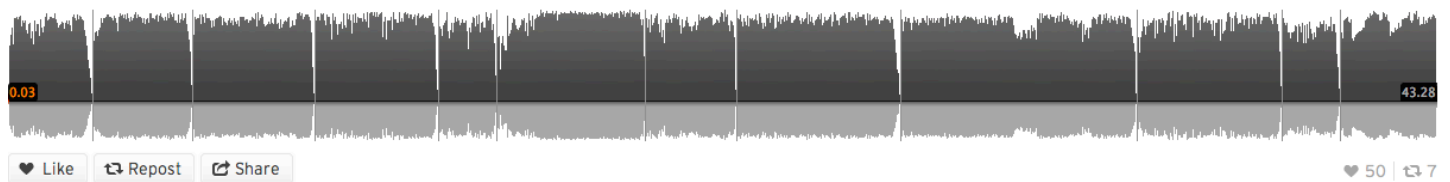

Imagem do widget inicial do Soundcloud de Rodrigo Campos. Esse espectro cinza é o espectro sonoro do disco Bahia Fantástica. Essa é uma das formas que os discos podem assumir num ambiente digital.

Nestes últimos 6 meses, Kiko Dinucci está bastante focado no lançamento do $2^{\circ}$ disco do Metá-Metá, o Metal Metal, e no $2^{\circ}$ disco do Passo Torto, o Passo Elétrico. O Soundcloud do Metá- Metá tem algumas músicas do primeiro disco e cada uma delas tem uma média bastante superior à média do Soundcloud que leva o nome de Kiko Dinucci. A faixa "Oba Iná”, por exemplo, estava, até dia 04 de Junho de 2013, com 6.375 reproduções, um número bastante próximo ao da música mais executada da página de Rodrigo Campos. Kiko Dinucci e 
Rodrigo Campos ainda possuem juntos o Soundcloud do Passo Torto onde publicaram as 12 músicas de seu primeiro disco.

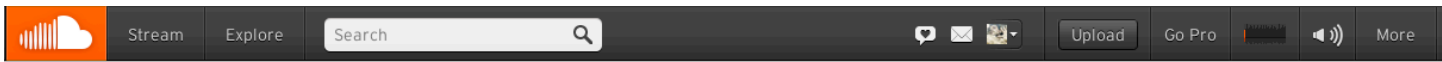

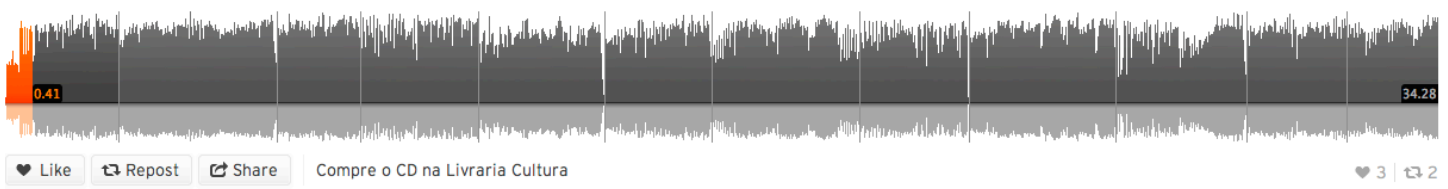

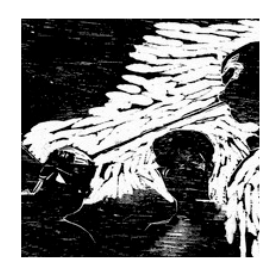

Released by:
vo Mania I I Dhr

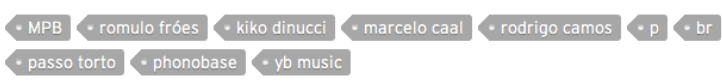

Passo Torto é a união dos compositores Romulo Fróes, Rodrigo Campos, Kiko Dinucci e do baixista e produtor Marcelo Cabral. Com referências distintas, Romulo, Rodrigo e Kiko, partem do samba, elemento em comum nos trabalhos dos três, para experimentar novas possibilidades à música brasileira.

This set contains 12 sounds, total time: 34.28

Imagem do Soundcloud do Passo Torto. Podemos observar aqui, abaixo do espectro sonoro, a capa do disco e algumas informações sobre a banda.

Entre esses músicos e artistas o Soundcloud basicamente é um espaço onde podem disponibilizar suas músicas para que qualquer um possa ouvir, compartilhar, curtir e divulgar. Conforme vão gravando músicas novas fazem o upload no site e divulgam através das redes sociais. Em cada widget, abaixo de cada espectrograma, o internauta encontra um ícone de compartilhamento onde automaticamente aparecem as opções de redes sociais na seguinte ordem: Facebook, Twitter, Tumblr e Pinterest ${ }^{92}$. Para poder interagir com as músicas online basta que o internauta seja cadastrado nessas redes. Através desse compartilhamento online cada disco digitalizado pode se espalhar pelo ciberespaço amplificando sua agência e fazendo com que o nome de cada artista circule mais.

\subsection{O uso do Facebook}

"Enquanto a internet começava e se transformar em uma plataforma para contribuição e colaboração, Mark Zuckerberg entrou para Universidade Harvard... Zuckerberg lançou o Facebook do seu dormitório na faculdade. Ele se mudou para a Califórnia naquele verão, pretendendo voltar a Harvard para se formar em ciência da computação. Em vez

${ }^{92}$ O Tumblr é chamado de plataforma de blogging, ou seja, é um site que oferece aos usuários a possibilidade de criarem blogs de forma simples e rápida. O Pinterest é uma rede social de compartilhamento de fotos. Nenhum dos dois foi citado pelos músicos e artistas com os quais conversei. 
disso, abandonou o curso e se tornou o executivo-chefe em tempo integral do Facebook, uma rede social arquetípica para amigos." (TAPSCOTT, 2010:71).

O criador do Facebook, Mark Zuckerberg, se tornou um dos nomes mais famosos e importantes da internet atual. Sua história já virou até um filme, “A Rede Social”, lançado em 2011, contando como o jovem estudante de Harvard criou o site que se tornaria a maior rede social do planeta com 1,1 bilhão de pessoas ${ }^{93}$. Não é mera coincidência o fato de ser a plataforma digital mais utilizada pelos artistas que são nossos interlocutores aqui. O Facebook é a única plataforma digital da qual todos os três participam ativamente (já que Tatá está fora do Soundcloud e Rodrigo fora do MySpace). Entre 2011 e 2012, posso afirmar que foram poucas as semanas em que Kiko, Tatá e Rodrigo não postaram nada do Facebook. A popularidade do site no mundo se reflete da mesma forma no meio artístico. Como já mencionei anteriormente existe até uma configuração do Facebook que permite a criação de uma página de artista. O Facebook é a rede onde artistas divulgam discos e shows de lançamento, além de compartilharem variados tipos de informação (filmes, notícias de jornal, opiniões políticas, desenhos etc.). Os discos virtuais amplificam seu alcance e, logicamente, sua agência em redes sociais como o Facebook. Os fãs interagem diretamente com os artistas (se estiverem conectados na mesma hora, interagem em tempo real). Autor-obra-público estão conectados tendo como intermediários os computadores, os servidores da internet e o Facebook.

Nesses últimos dois anos, para falar só do universo musical, essa rede social foi palco de alguns casos curiosos. Um desses casos foi o de Tom Zé que lançou, dia 22 de Abril de 2013, um disco chamado Tribunal do Feicebuqui respondendo às criticas que havia recebido dos fãs, através do próprio Facebook, por causa de sua participação numa campanha televisiva da Coca Cola ${ }^{94}$. Por coincidência, ele convidou Kiko Dinucci e Tatá Aeroplano, entre outros jovens artistas, para participarem do disco tocando, cantando e compondo. Copiei algumas publicações que encontrei no mural de notícias do Facebook no dia do lançamento. Para esclarecer o leitor sobre as pessoas e textos que aparecem nesses posts vale colocar o

\footnotetext{
93 Dados relativos ao Facebook Extraídos do site: http://olhardigital.uol.com.br/jovem/digital news/noticias/facebook-tem-751-milhoes-de-usuarios-emplataformas-moveis, dia 14/05/2013 às 11:43 hrs.

${ }^{94}$ Tom Zé nem aparecia na propaganda, somente sua voz foi utilizada. Ele atuou como o locutor de uma propaganda de TV da Coca Cola que foi bastante veiculada no início de 2013. Para os fãs do cantor foi extremamente fácil reconhecer sua voz. Estes mesmos fãs se sentiram traídos de alguma forma pelo fato do artista realizar um trabalho para a Coca Cola.
} 
seguinte: nesse dia, entrei no mural de notícias do Facebook e vi que Sil Ramalhete, produtora de shows que trabalha com Tatá Aeroplano e com a banda Trupe Chá de Boldo, havia postado o primeiro trecho que copiei. Em seguida fui até a página de Marcelo Segreto, outro jovem artista que foi convidado por Tom Zé para o disco, e copiei os posts dos amigos do artista, Acauam Oliveira e Thiago Ricarte, além do post do próprio Marcelo Segreto sobre o lançamento.

Vimos no capítulo anterior, a partir da teoria da agência elaborada por Gell (1998), como os discos agem, como eles fazem eventos acontecerem e como transformam a vida das pessoas envolvidas. Nesse caso do Tom Zé respondendo aos fãs através de um disco, poderíamos pensar no artista como agente primário, no disco como agente secundário e no público do Facebook como recipiente da agência. O disco age restabelecendo a imagem pública do artista após uma sucessão de críticas de seus fãs no ciberespaço.

$\left[\right.$ Tom Zé Agente $1^{\circ} \rightarrow$ Disco Agente $2^{\circ}$ ] $\rightarrow$ Público no Facebook Paciente

Entretanto, nem todos do público são meros pacientes da agência do disco. Muitos apoiam a iniciativa de Tom Zé e utilizam o disco virtual de tal forma que se tornam (co)agentes, ou seja, aqueles que compartilham o link do disco e manifestam sua opinião em favor do artista também estão, de certa forma, agindo sobre o resto do público que recebe essas publicações via Facebook. Esse é o caso de Sil Ramalhete, de Thiago Ricarte e Acauam Oliveira. Outra agência fundamental do disco Tribunal do Feicebuqui foram as próprias composições. Tom Zé encomendou de alguns artistas da nova cena musical composições inspiradas no episódio. Marcelo Segreto, jovem líder da banda Filarmônica de Pasárgada, foi um dos compositores convidados ao lado de Emicida, O Terno, Kiko Dinucci, Tatá Aeroplano e Trupe Chá de Boldo. 
EP com 5 músicas para baixar de graça. Tom Zé, Trupe Chá de Boldo, Tatá Aeroplano, O Terno, Emicida e Filarmônica de Pasárgada.

\section{Tom Zé, Mané. Culpado.}

Maraviglia criar junto com ele e ainda poder ficar mais perto da

Filarmônica de Pasárgada, O Terno, Tatá Aeroplano e Emicida .

EP novinho com 5 músicas pra baixar inteiramente free em

www.trupechadeboldo.com

ou

www.tomze.com.br

beijo

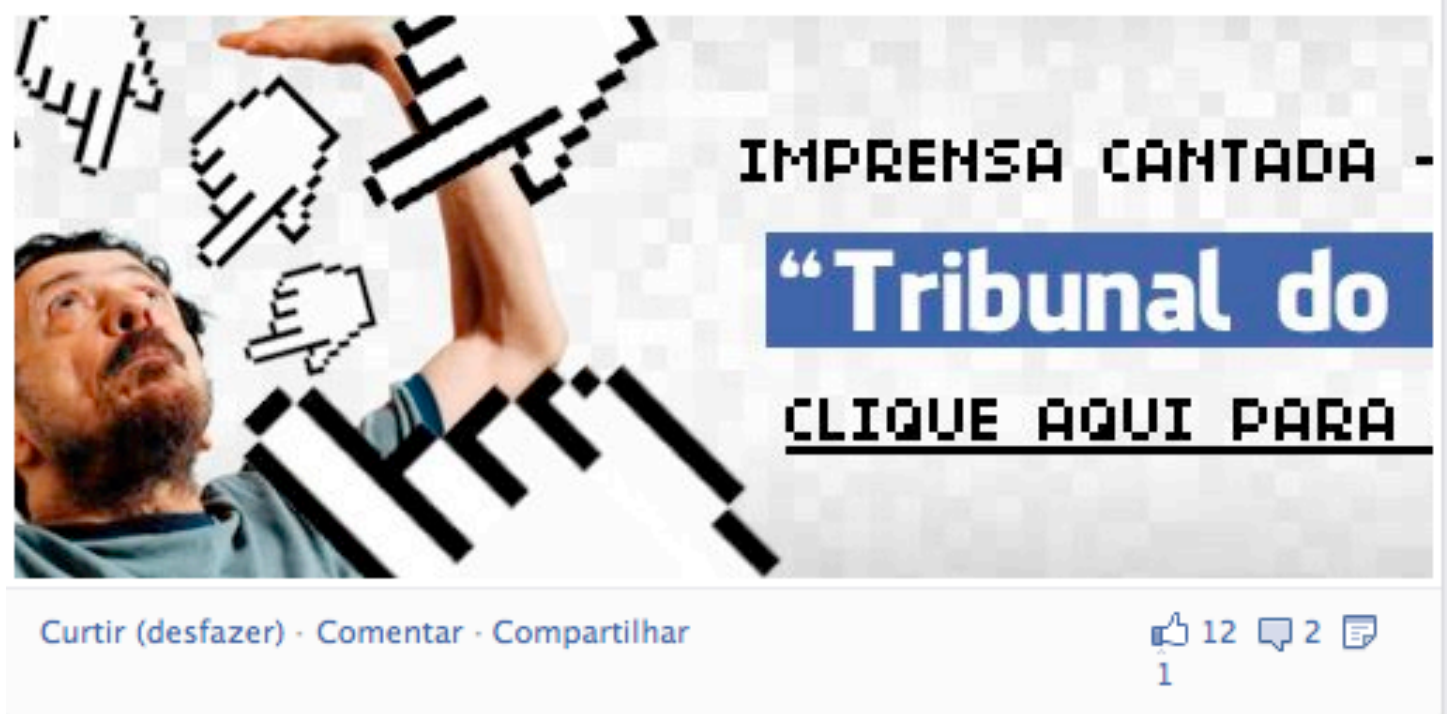

Post de Sil Ramalhete no dia do lançamento do Tribunal do Feicebuqui 
3

Marcelo Segreto compartilhou a foto de Filarmônica de Pasárgada.

22 de abril $(2)$

Para baixar o novo EP de Tom Zé com 5 músicas gravadas com Tatá Aeroplano, Trupe Chá de Boldo, Emicida, Filarmônica de Pasárgada e 0 Terno! Entre no site: http://www.tomze.com.br/

Lançamento do EP de Tom Zé, "Tribunal do Feicebuqui"! Gravado com Filarmônica de Pasárgada, Tatá Aeroplano, Trupe Chá de Boldo, 0 Terno e Emicida.

Download aqui: www.tomze.com.br

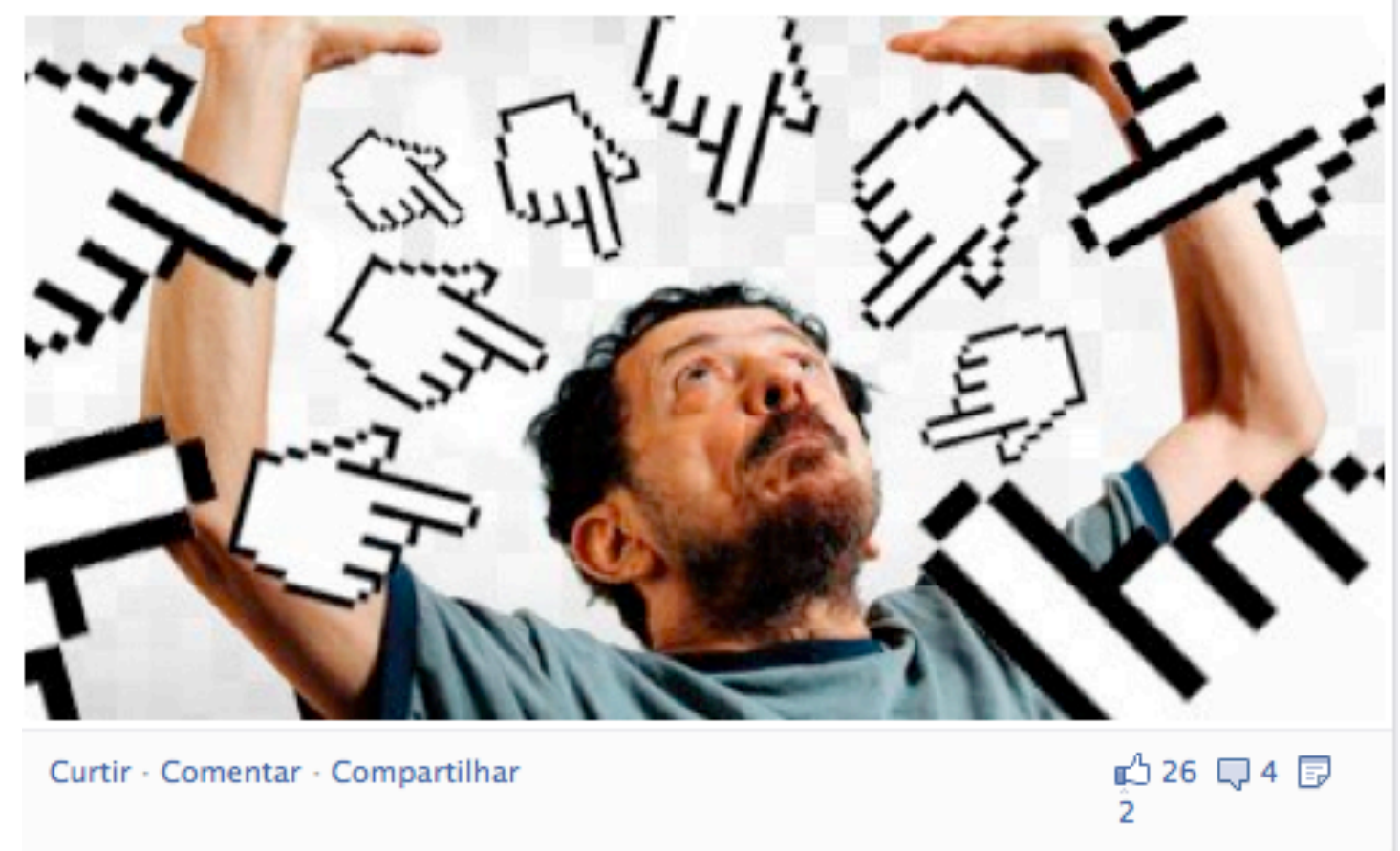

Marcelo Segreto no dia do lançamento do Tribunal do Feicebuqui

TRIBUNAL DO FEICEBUQUI

(Marcelo Segreto / Gustavo Galo / Tatá Aeroplano / Emicida)

Tom Zé mané

Baixou o tom

Baba baby

Bebe e baba

Velho babão

Tom Zé bundão

Baixou o tom 
Baba baby

Bebe e baba

Mané babão

Seu americanizado

Quer bancar Carmen Miranda

Rebentou o botão da calça

Tio Sam baixou em sampa

Vendido, vendido, vendido!

A preço de banana

Já não olha mais pro samba

Tá estudando propaganda

Que decepção

Traidor, mudou de lado

Corrompido, mentiroso

Seu sorriso engarrafado

Não ouço mais, eu não gostei do papo

Pra mim é o príncipe que virou sapo

Onde já se viu? Refrigerante!

E agora é a Madalena arrependida com conservantes

Bruxo, descobrimos seu truque

Defenda-se já No tribunal do Feicebuqui

A súplica: Que é que custava morrer de fome só pra fazer música?

Esta é a letra da primeira faixa do disco e como podemos ver ironiza as acusações que Tom Zé sofreu na rede social. Não temos tempo de entrar em detalhes musicais agora, por ora vale notar que os posts trazem o link com as músicas e uma imagem de Tom Zé segurando várias mãos com os indicadores apontados que seria uma espécie de capa. Essa é uma característica marcante dos discos disponibilizados no ciberespaço, eles são a reunião entre músicas e imagem. Os artistas fazem questão de juntar uma capa aos arquivos de MP3 que compõem um disco virtual aproximando a experiência do ouvinte o máximo possível de um disco físico. O disco de Tom Zé também tem uma forte carga política, cada detalhe é importante. A imagem da capa, por exemplo, nos remete ao um julgamento digital com as mãos inquisidoras semelhantes às mãos que aparecem num computador quando mexemos um mouse e 
semelhantes às mãos com o polegar levantado utilizadas como ícone de que alguém "curtiu" algo no Facebook.

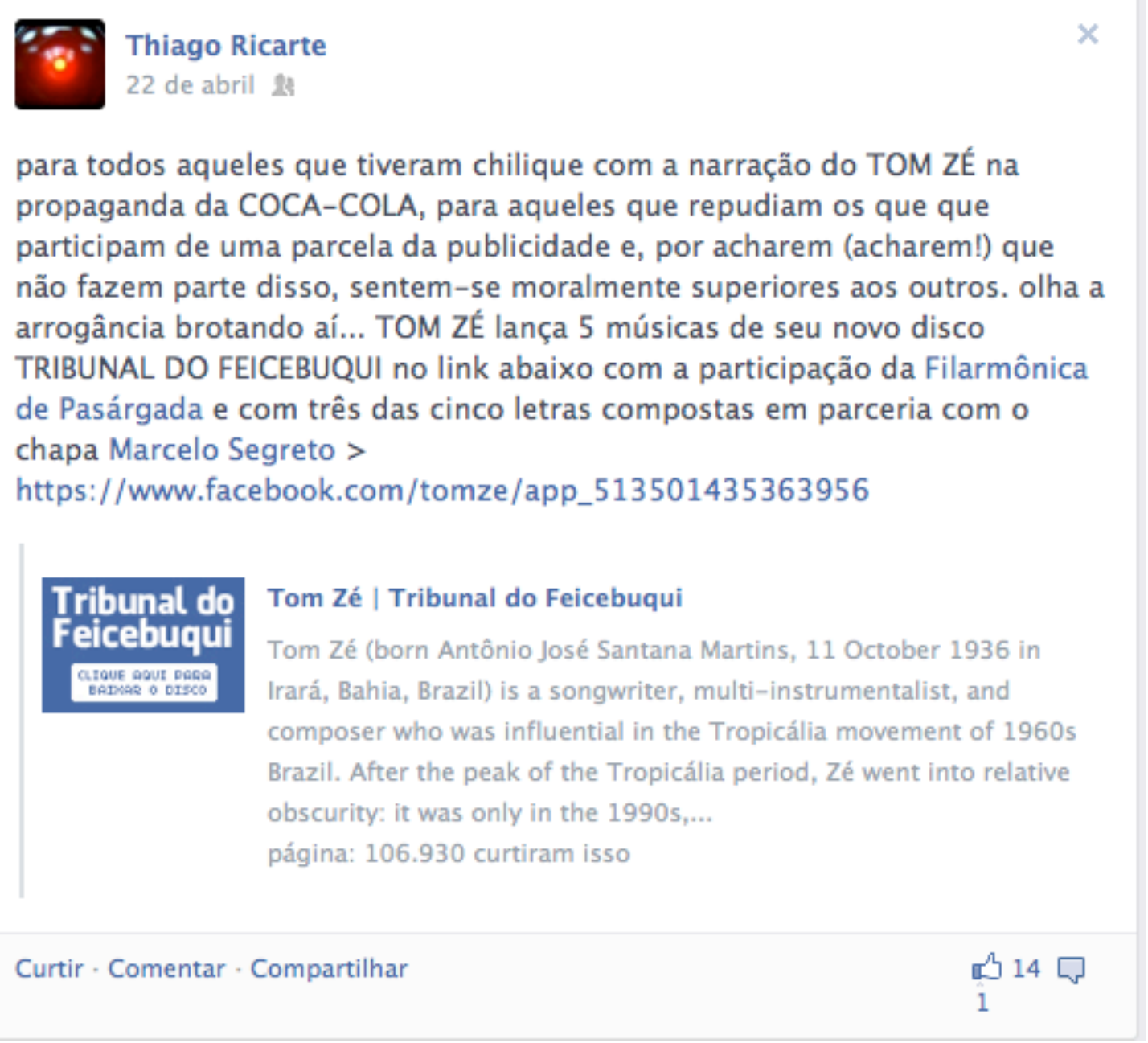

\section{Post de Thiago Ricarte no dia do lançamento do Tribunal do Feicebuqui}

O disco agindo na internet provoca reações como a de Thiago Ricarte e de Acauam de Oliveira, que se colocam como verdadeiros advogados de defesa. Ao mesmo tempo em que defende Tom Zé, este disco promove o nome de novos artistas da cena musical paulistana. Dito de outra forma, o disco ajuda no processo sempre dinâmico de construção dos artistas. O nome de Marcelo Segreto, por exemplo, circulou por locais do ciberespaço que não circularia sem o disco. O disco age na construção de Marcelo Segreto como artista.

Tribunal do Feicebuqui Agente $\rightarrow$ Marcelo Segreto Paciente 
Prévia do novo disco do Tom Zé, Tribunal do Feicebuqui, se posicionando em relação a polêmica com relação ao comercial da Coca Cola. Algumas razões para ouvir:

1)Pode baixar o EP de graça no site.

2) O som feito com a nova cena musical de São Paulo, está atualíssimo. E, ao mesmo tempo, ainda é muito Tom Zé.

3) É uma puta mostra de respeito e consideração com os fãs. Responder \ assimilar a crítica com arte.

4) É uma baita resposta: não foi o Tom Zé que fez propaganda pra coca. A coca é que fez propaganda pro Tom Zé.

5) 3 das 5 canções são em parceria com o camarada Marcelo Segreto! 0 cabra é bom, talentoso e muito inteligente, e ser reconhecido por esse monstro da MPB (e outros, como Luiz Tatit) não é pra qualquer um. Parabéns pra Filarmônica de Passárgada e pra Trupe Chá de Boldo.

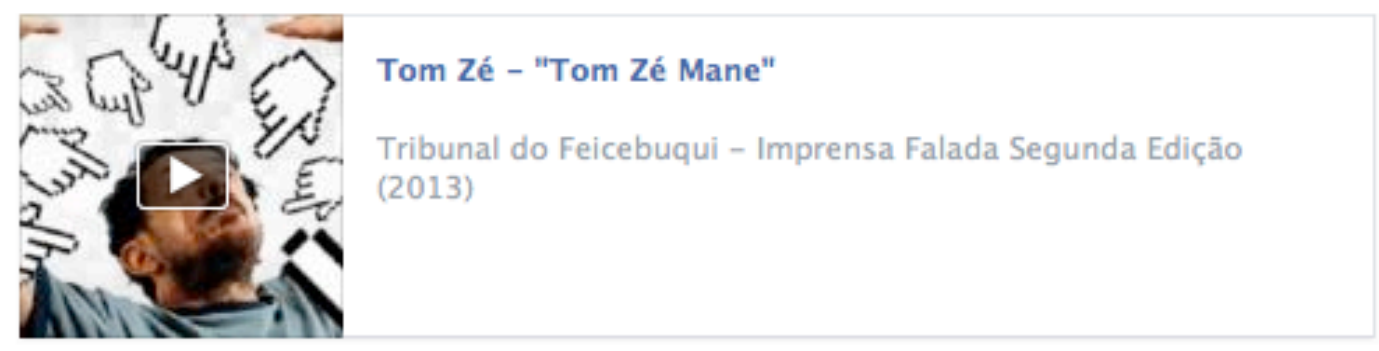

Curtir - Comentar - Compartilhar

Post de Acauam Oliveira no dia do lançamento de Tribunal do Feicebuqui

Exploramos com um certo detalhe esse caso do Tom Zé porque ele se deu todo dentro e por causa do Facebook, conectando dois dos artistas que são nossos interlocutores na pesquisa Kiko Dinucci e Tatá Aeroplano. Esse caso também representa um rico exemplo de como um disco age, mais especificamente, como um disco virtual é capaz de agir no ciberespaço através de uma rede social como o Facebook. Esses posts exemplificam bem como a rede social conecta rapidamente atores diversos envolvidos num assunto comum. O Facebook foi o sujeito de uma série de ações - propiciou um “julgamento online”, uma resposta do réu (Tom Zé) através de um disco e a divulgação dessa resposta. Vemos aqui diversas agências e agentes em jogo, o Facebook, os artistas, a Coca Cola, uma propaganda na TV, um disco virtual, amigos e simpatizantes de Tom Zé. Humanos e Não-humanos interagem e se (co)produzem mutuamente. Fica difícil determinar com clareza quem é sujeito e quem é 
objeto. Tom Zé, por exemplo, foi ora objeto de críticas, via rede social digital e ora sujeito, reunindo um coletivo de jovens artistas para produzir rapidamente um disco. $O$ disco emerge como um sujeito actante que (re)estabelece a imagem do artista perante seus fás inquisidores. Até mesmo os textos de apresentação, que aparecem juntos na pasta que contém os arquivos em MP3 com as músicas, humanizam o disco. Tom Zé provocativamente nos apresenta uma certidão de nascimento do disco. A imagem a seguir é uma fotografia da primeira página dos textos do disco.

\section{Tribunal do Feicebuqui}

\section{Certidão de nascimento}

Nasceu aos 22 dias do mês de abril, sob o signo de In-Touro-Net, o filho do coca-colismo espermatizado pelos amigos do Tom Zé.

Nome de batismo: TRIBUNAL DO FEICEBUQUI

Padrinhos: Daniel Maia, Emicida, Filarmônica de Pasárgada, Tatá Aeroplano, O Terno

e Trupe Chá de Boldo.

Paternidade: Marcus Preto

Parteira: Neusa Martins

Assistente: Tania Lopes

Vale citar rapidamente outro caso envolvendo membros dessa comunidade de músicos que aconteceu dentro do Facebook. Trata-se da rejeição ampla de alguns comentários maldosos do consagrado cantor Ed Motta sobre novos artistas da música brasileira durante o mês de maio de 2011. Ed Motta foi execrado publicamente perante uma ampla rede de pessoas que se solidarizaram com os nomes atacados ${ }^{95}$. A popularidade do cantor se viu abalada e muitos que se diziam fãs iniciaram uma campanha de repúdio público. Uma onda de solidariedade tomou conta de um grupo de artistas e de seus fãs fortalecendo seus laços sociais dentro da rede. Recuero (2009) utiliza as noções de interação, relação e laço sociais para analisar as conexões entre atores nas redes sociais. A interação seria a matéria prima básica que formaria, ao longo do tempo, relações e laços mais profundos entre os atores. "O laço é a efetiva conexão entre os atores que estão envolvidos nas interações. Ele é resultado, deste modo, de sedimentação

\footnotetext{
${ }^{95}$ Dentre os mais atacados por Ed Motta estavam Tulipa Ruiz e Rômulo Fróes. Tapscott (2010) fala no perigo que é se expor totalmente no Facebook. Segundo o autor, os usuários, especialmente os mais jovens, estão se acostumando a publicar tudo sobre suas vidas. O maior perigo do Facebook seria justamente a perda da privacidade. Ed Motta tornou pública uma opinião pessoal que acabou o constrangendo perante grande número de pessoas. As fronteiras entre público e privado estão perigosamente borradas.
} 
das relações estabelecidas entre agentes.”(RECUERO, 2009:38). Os artistas interagem bastante com seu público via Facebook, casos como este que envolveu Ed Motta mobilizaram tanto os atores, que muitas interações simples (como um post elogiando um disco ou divulgando um show) se aprofundaram podendo estabelecer relações mais duradouras. $\mathrm{O}$ mesmo pode ser dito para o caso do Tribunal do Feicebuqui. Esses casos nos levam a reconhecer a importância do Facebook na sociedade online.

Em suas páginas, os artistas constroem no Facebook uma imagem pública de si mesmos disponibilizando diversas informações como fotos, agenda de shows, vídeos que curtiram, comentários de fãs e, é claro, os links que direcionam seus seguidores aos seus discos e músicas digitalizados. A seguir alguns exemplos dessa atuação divulgando o lançamento de discos:

\section{"Rodrigo Campos}

Outubro de 2012

Lembrando que estaremos vendendo o vinil do Bahia Fantástica, em primeira mão, no lançamento, dia 10 (flyer). Mas quem não puder ir, ou não quiser, mas quer comprar o vinil, já pode encomendar aqui:http://www.gomagringa.com/" (Rodrigo Campos divulgando o lançamento do Vinil e o site de vendas)

\section{"Kiko Dinucci}

Dezembro de 2012

Tem gente se abraçando, gente rindo, gente chorando, gente bebendo, gente transando, usando droga, gritando feliz ano novo.

Existe gente que não bate bem do juízo e lança mais DOIS discos na primeira hora de 2013.

Boa viagem!

\section{DUAS SESSÕES (2013) | thiago frança}

thiagofrancaoficial.blogspot.com.br" (Kiko Dinucci divulgando o lançamento de dois discos gravados com seu colega Thiago França)

Este último post de Kiko divulgando os discos com seu colega e parceiro Thiago França é revelador da intensidade da produção fonográfica dessa geração. Os dois iniciaram o ano de 2013 lançando dois discos que são divulgados nas primeiras horas do ano novo através do 
Facebook. Seguir a atuação de artistas e músicos no Facebook não revela somente dados sobre o universo artístico e musical, é também um método de captar dados importantes sobre valores, práticas, estéticas, agências e até posições políticas. Dia 26 de Junho de 2012, por exemplo, Kiko Dinucci manifestou pensamentos políticos sobre o centro e a periferia de São Paulo.

"Kiko Dinucci compartilhou um link.

26 de Junho de 2012

Ando pensando bastante ultimamente em como a 'classe média cultural' paulistana se isola cada vez mais na Zona Oeste. Não falo de Perus ou Jaraguá, falo de Perdizes/Sumaré/Pompéia/Pinheiros e principalmente da badalada Vila Madalena.

Av. Paulista virou um centro mais ou menos perto. O centro, por sua vez, virou uma periferia e só será habitada por essas pessoas quando o Kassab terminar o seu trabalho de expulsar os pobres da região.

No fim das contas, tudo que a classe média consegue fazer é imitar a favela, construindo os seus prédios desordenados e se isolando como um periférico que passa a vida toda sem ultrapassar quatro quarteirões.

São Paulo é um pouco maior que a Vila Madalena.

"Quem te prendeu? Quem te impediu? Qual foi o muro que subiu?"'

Como já mencionei antes, Kiko Dinucci também é artista plástico, tendo feito diversas capas de disco e flyers entre outras obras. Recentemente ele começou a utilizar o Facebook de forma extremamente original e criativa para divulgar rapidamente seus shows, postando uma série de desenhos feitos à mão onde convida o público. Durante dois finais de semana seguidos de maio de 2013, quando aconteceram as Viradas Culturais de São Paulo - 18 e 19 na capital, e 25 e 26 no interior do estado - Kiko Dinucci se empenhou em divulgar os shows do Metá-Metá e do Passo Torto através desses desenhos. Utilizando um IPhone ele rapidamente fotografa cada desenho e coloca no ciberespaço. O potencial de uma rede social como o Facebook na divulgação da música é redescoberto a cada novo uso por parte dos artistas. A maior parte dos desenhos postados por Kiko Dinucci tem um forte apelo sexual como o que reproduzo a seguir: 


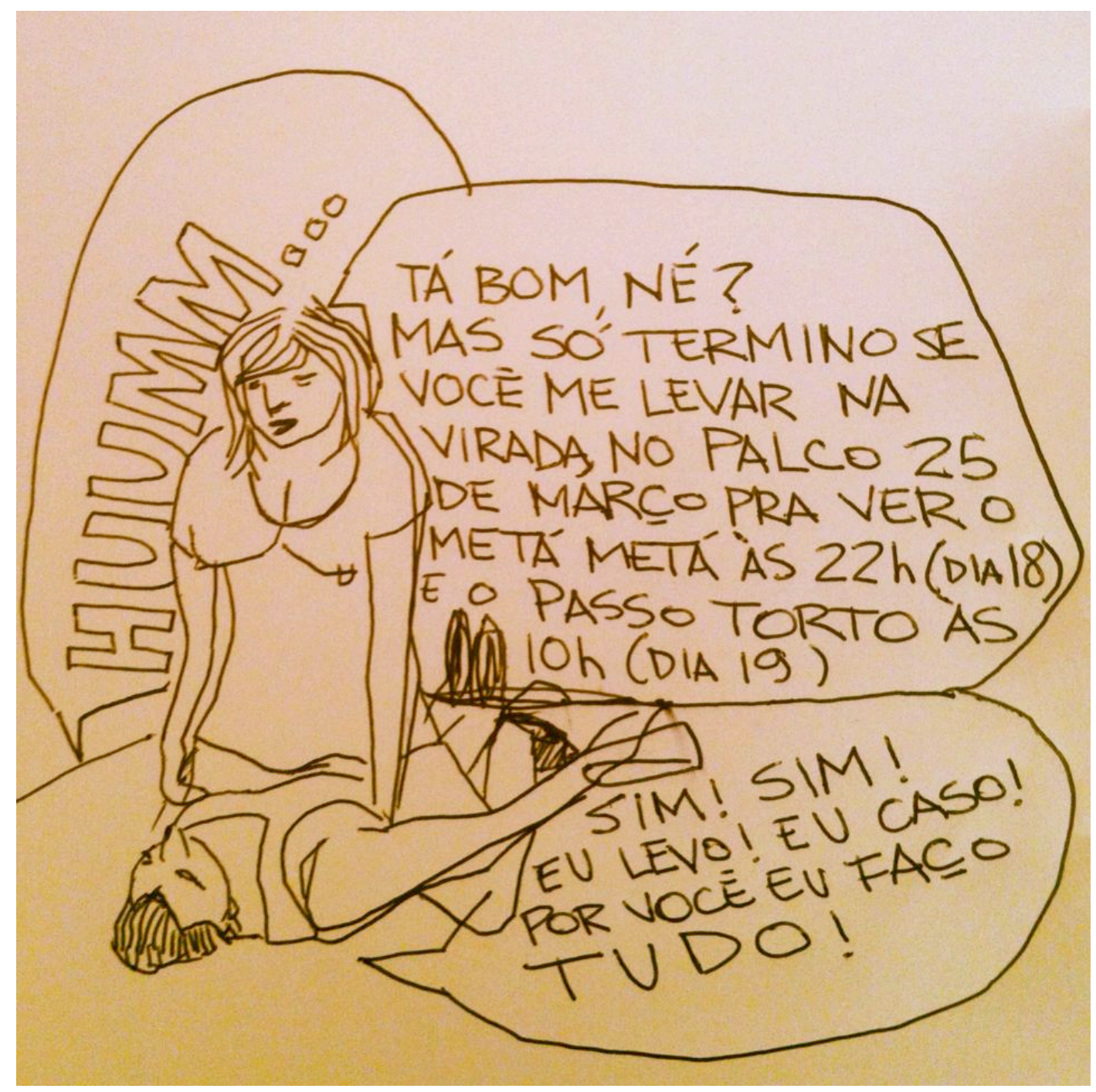

Esse tipo de propaganda rápida e divertida seria impensável sem as redes sociais da Internet. $\mathrm{O}$ artista tem liberdade e autonomia para criar formas de conexão rápidas e diretas com o público que pretende atingir. É também uma espécie de curto-circuito entre arte e público; $a$ cibercultura é caracterizada pela eliminação dos intermediários representados anteriormente pelas mídias de massa (Rádio e TV), pelas grandes agências de propaganda e pelas gravadoras.

Dia 03 de Abril de 2013 Tatá Aeroplano divulgou o show que realizaria dia 8 no Sesc Consolação pelo projeto, "Vinil é coisa do Futuro" com artistas que optaram por lançar seus trabalhos também em Vinil. 
No fim de semana agora rola no Teatro Anchieta - SESC Consolação vai rolar o projeto "Vinil: Coisa do Futuro", com artistas que optaram em lançar também o disco no formato Vinil! Sexta, dia 07, tem show do disco "Pra Viagem" da Kika Ki Ka , Sábado dia 08 o show do meu disco, e dia 09 tem Rodrigo Campos, com show do disco "Bahia Fantástica"!

Viva la bolacha!

http://www.facebook.com/events/293338734136876/?fref $=$ ts

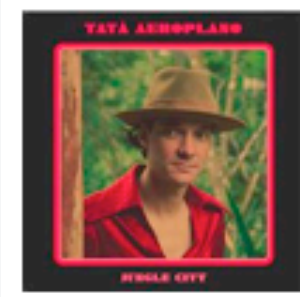

Show Tatá Aeroplano no Teatro do SESC Consolação 8 de Junho às 21:00

Teatro do SESC Consolação em São Paulo

A

Participar - Vocế foi convidado por Tatá Aeroplano e Sil Ramalhete

Curtir (desfazer) - Comentar - Compartilhar

Post de Tatá Aeroplano divulgando show

Esse post representa bem o elo que existe entre esses artistas e que corrobora a opção adotada neste trabalho por agrupá-los como um conjunto de pessoas que compartilha ideias sobre música. Mesmo tendo trabalhos musicalmente variados estes artistas compartilham ideias sobre como produzir e lançar suas músicas. O projeto do Sesc "Vinil: Coisa do Futuro" captou justamente essa conexão ao convidar artistas que estão apostando no disco de vinil. A conexão entre eles é mais profunda. Os discursos a respeito da internet, a respeito de como se comunicar com o público e de que tipo de relação estão construindo com seu público se assemelha muito entre eles.

Kiko Dinucci: “A gente se reinventou mas os produtores não se reinventaram. O mainstream é uma massa sem face, não basta o público se identificar com você, você precisa se identificar com o público. Quando eu me deparo com meu público, sei que eles gostam de coisas que eu gosto, filmes, música, cultura. Gosto de olhar pro meu público e 
deduzir que eles não saem batendo em mendigos ou gays. Creio que no esquema do maistream essa relação se perde.” (Entrevista de Kiko Dinucci, dia 04/06/2013).

Tatá Aeroplano: "Não têm mais esquema. Pra que eu vou querer um esquema, uma gravadora? Hoje em dia eu mesmo faço tudo, não preciso de intermediário, tá tudo lá, tenho controle de tudo. Pelo meu site sei todas as pessoas que baixaram meu disco." (Entrevista com Tatá Aeroplano, dia 24/03/2013).

Pelo que me informaram, pode-se afirmar que Tatá, Kiko e Rodrigo concentram suas atividades no ciberespaço no site do Facebook. Mesmo tendo perfis e páginas em outros sites (Youtube, Myspace, Soundcloud), o Facebook hoje se configura como a ferramenta digital mais utilizada para divulgação de discos e de shows. Kiko e Tatá possuem sites que realimentam tudo que divulgam via Facebook. O site é bastante valorizado, especialmente pelo Tatá, por permitir uma comunicação direta com público, com contratantes de show, com jornalistas. Tanto Tatá quanto Kiko possuem uma pasta padrão onde o contratante de show e/ou o jornalista pode baixar todas as informações necessárias sobre seus trabalhos mais recentes (releases, fotos, músicas, mapa de palco etc.). Rodrigo Campos não possui site, concentrando ainda mais suas atividades no mundo digital no Facebook.

\subsection{O uso dos sites}

Tatá Aeroplano e Kiko Dinucci, além de atuarem na internet usando as redes sociais que mencionamos anteriormente, utilizam sites pessoais para divulgarem sua obra. O ponto comum dos dois sites é o fato de seus discos estarem disponibilizados para download gratuito. No site de Kiko, como veremos na imagem abaixo, o disco Metal Metal ocupa a página de abertura deixando claro que o que mais interessa para o artista é que o visitante baixe seu último lançamento. Comparando os dois sites vemos que o site de Tatá é um pouco mais elaborado, com mais janelas, imagens e informações. Ele conseguiu centralizar diversas informações dentro do site: agenda de shows, fotos do instagram, textos, material para imprensa, àlbum para baixar e disco para comprar. O visitante não é direcionado para nenhum outro endereço quando entra em seu site. 


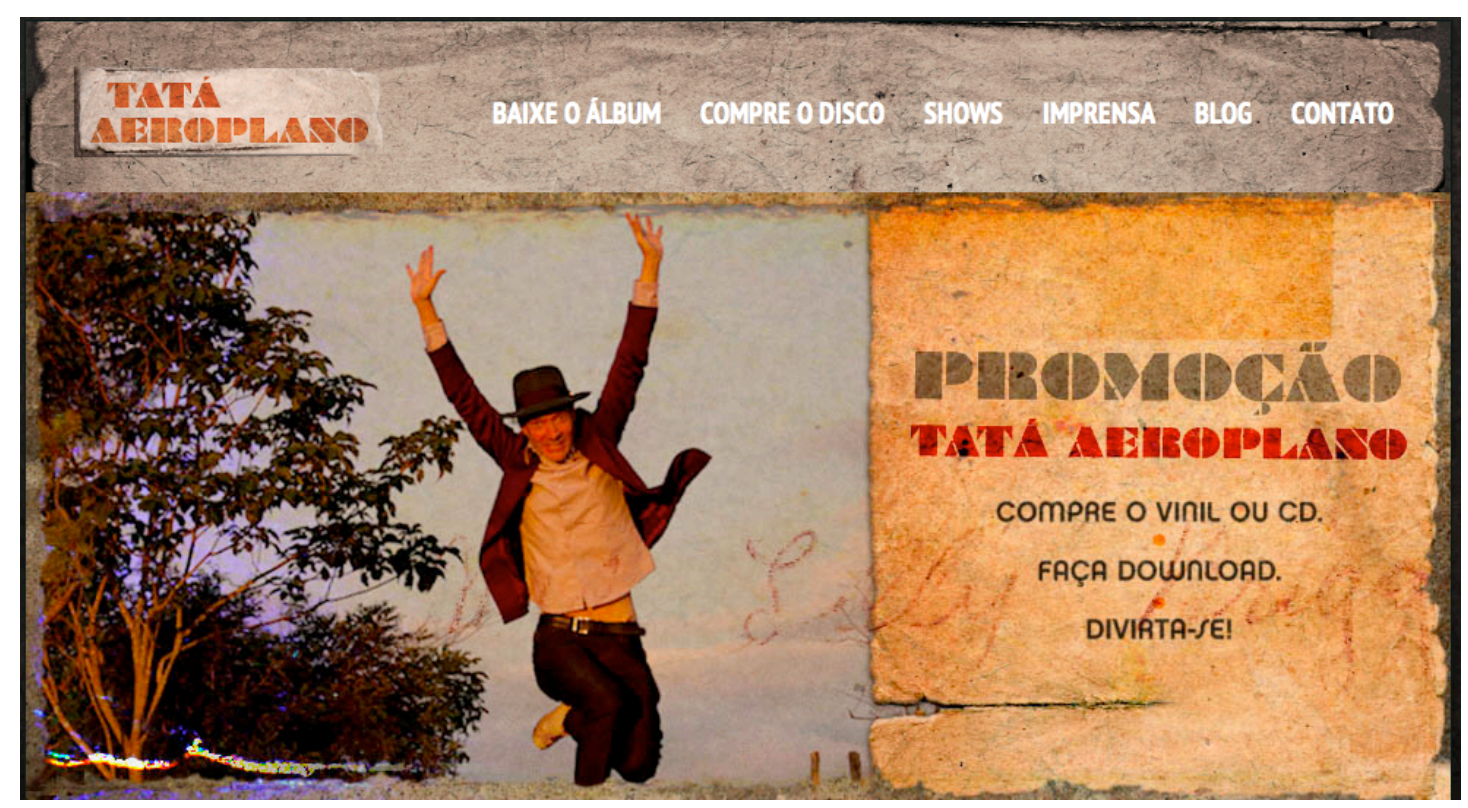

Imagem inicial do site de Tatá Aeroplano

No caso de Kiko, algumas janelas (como a de gravuras, por exemplo) levam o visitante a um outro endereço do ciberespaço (no caso das gravuras ao Flickr).

HOME | OUTROS DISCOS I GRAVURAS | EXU | O OLHO DERRAMADO

DOWNLOADEM 320 KBPS

download via MediaFire

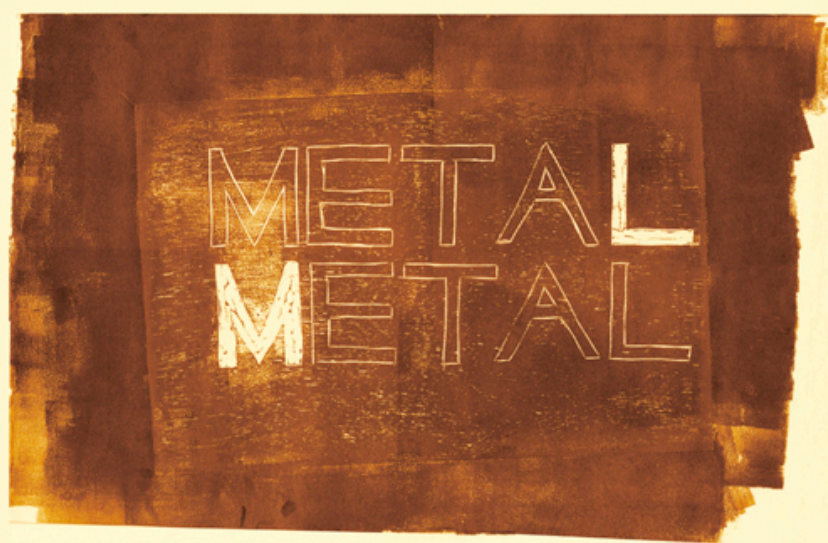

desmita

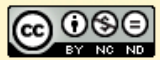

METAL KIT

contato:meta.dsm@gmail.com

Imagem inicial do site de Kiko Dinucci 
Uma diferença interessante entre os dois sites é a forma como disponibilizam o disco. Nos dois casos estão de graça, porém no site de Tatá Aeroplano, o público é obrigado e deixar informações de contato quando clica na janela "baixe o álbum." A imagem abaixo é uma foto da página que se abre quando clicamos nessa janela.

\section{BAIXE O ÁLBUM}

\section{* Campos obrigatórios}

Seu nome $\left(^{*}\right)$

Email (*)

Seu telefone (DDD+Número)

(XX) XXXX-XXXX

Deseja receber notícias sobre meu trabalho? (*)

$\square \mathrm{SIM} \square \mathrm{NÃO}$

\section{Enviar}

Dessa forma, Tatá mantém o controle sobre quantas pessoas baixaram seu disco e sobre quem baixou seu disco. "Eu sei todo mundo que baixou meu disco, eu conheço meu público, tenho e-mail de todos" ele me afirmou mais de uma vez, quando falávamos sobre seu site e sobre a internet. Kiko também já falou sobre a importância de conhecer seu público e saber quem está na plateia de seus shows. Porém, em seu site ele não tem ideia exata de quem está baixando seu disco. No caso do Metal Metal, ao clicar na imagem do disco que aparece na primeira página do site, o visitante inicia automaticamente o download de uma pasta que contém, além das músicas, um kit com release e fotos. No site de Tatá Aeroplano, essas informações estão divididas em duas janelas diferentes - uma para as músicas e outra na janela de "imprensa" com o release e fotos. De qualquer modo, em ambos os casos um contratante de shows rapidamente obtém todas as informações que necessita para fechar um show com os artistas.

Interessante notar que, apesar de se referirem nas entrevistas e conversas informais aos “discos" para baixar, no site de Tatá encontramos uma diferença entre "álbum" e "disco." Na 
imagem que copiei acima, podemos ler "Baixe o Álbum" e ao lado "Compre o Disco", o que nos leva a considerar que as músicas em arquivo digital para download gratuito constituem um álbum digital, ao passo que o disco para comprar são os discos de vinil e os CDs físicos. Esta, talvez seja um pista importante de como organizar os termos e/ou a nomenclatura que utilizamos para expressar essas obras musicais que se desdobram em formas físicas e virtuais. Vale lembrar novamente que Marcia Tosta Dias (2012) conseguiu organizar bastante a confusão reinante entre estudiosos que escrevem sobre música em relação à proliferação de termos. Em sua análise, suporte é diferente de formato, álbum é diferente de disco e de single.

"Da mesma maneira que o desenvolvimento da indústria fonográfica se fez a partir da interação entre os suportes nos quais o registro musical era feito e os aparelhos destinados à sua leitura e reprodução, tais suportes materiais definiram também um formato para as obras registradas. $\mathrm{O}$ formato, dado inicialmente pelas características físicas e técnicas do suporte, refere-se às qualidades e especificidades musicais e estéticas que o registro pode conter e alcançar. Assim, por mais que tenham sido vários os tipos de suporte que já deram corpo às gravações (cilindros, os vários tipos de discos, compactos, LPs, K7s, CDs, arquivos digitais, como o MP3, dentre outros) deles derivaram essencialmente dois tipos de formatos: o álbum e o single.” (DIAS, 2012:65)

A autora aponta para uma tendência do consumo de música digital se realizar através de faixas individuais (os singles) e não mais de álbuns completos, que seriam a reunião de um número maior de faixas e que fazem sentido quando tocadas juntas. $\mathrm{O}$ álbum seria um formato e o disco seria um suporte. Um álbum pode ser digitalizado e baixado no site de Tatá, porém os discos, tanto CDs quanto vinis seriam somente o artefato físico. Essa distinção analítica é bastante importante para nos auxiliar na observação desse universo de produção musical. No caso de músicas que somente são lançadas virtualmente parece sensato utilizar o termo álbum. Entretanto, adotamos o termo disco ao longo de toda nossa pesquisa porque assim nossos "nativos" falavam nas entrevistas e conversas. Podemos ser acusados de superestimar o disco e sobrecarregar o termo de sentidos e de agências, afinal falamos o tempo todo em como os discos agem, em como os discos constroem artistas, em como os discos são processos sociais ricos. Vale a pena correr esse risco se conseguirmos com essa pesquisa dar conta de reconfigurar o lugar social desses objetos valorizando criticamente o discurso de nossos interlocutores. Numa entrevista que concedeu a Juliano Polimeno (agora como diretor de marketing da distribuidora digital de música ONErpm), Tatá Aeroplano mistura com clareza de raciocínio os termos "disco" e "álbum." Nossa tentativa analítica de purificar os termos se enfraquece na vivacidade do discurso nativo cheio de nuances e hibridismos. A cópia da entrevista me foi fornecida por Tatá Aeroplano, depois que fiz uma 
serie de perguntas sobre números de vendas de discos. Na verdade, essa entrevista acabou não sendo publicada no site da ONErpm.

\begin{abstract}
"Nós, seres humanos de 2013 vivemos fragmentadamente já ... o filme "Holy Motors" que vi no cinema três vezes, foi até agora, a melhor maneira de explicar essa fragmentação. A música hoje pode ser ouvida de todas as maneiras ... então eu parto do seguinte principio. O principio básico. Um disco pra mim é como se fosse um livro, um filme. Por isso eu trabalho sempre o conceito do álbum. Tem galera que ainda curte o álbum, escutar o disco do começo ou fim, tem galera que gosta de uma música ... e nem escuta mais o disco, o álbum. Tem gente que só escuta música no Youtube ... tem galera que escuta no vinil ... e acho que dá para mostrar como o mercado funciona atualmente basta eu lançar esses números que talvez explique melhor.” (Entrevista realizada por Juliano Polimeno com Tatá Aeroplano para o site da ONErpm)
\end{abstract}

Os números que Tatá lança em seguida são de suas vendas e downloads. No dia em que solicitei esses dados, 10 de Junho de 2013, ele me passou o seguinte: downloads gratuitos quase 10.000 downloads; CDs prensados - 2.000 unidades - 672 peças vendidas da primeira prensa. Vinil - 250 unidades fabricadas - ainda tem 23 peças pra vender; Vendas digitais - 10 vendas do álbum digitalmente / 42 vendas de canções avulsas / 845 streamings. Kiko Dinucci também nos forneceu o número de downloads do Metal Metal pelo site, foram 26.184 downloads até dia 10 de Junho de 2013. Ele ainda fez um cálculo aproximado de quantos downloads teriam sido feitos via outros sites de música como o "Musicoteca", "Um Que Tenha" e "Hominis Canedae". Juntando tudo daria um número de quase 30 mil downloads. Os sites emergem como grande ferramenta de divulgação de obras musicais na cibercultura, colocando o artista em contato direto com seu público.

\title{
3.7. Curto-circuito comunicacional entre artistas e público
}

Nossa opção nesta pesquisa foi amplificar o alcance da palavra disco reconfigurando seus significados para abarcar tanto a ideia de formato quanto de suporte, mesmo tendo consciência da distinção proposta por Dias (2012). Nos três casos abordados, o disco físico e o disco virtual caminharam lado a lado. Nenhum dos artistas lançou somente um ou outro. Vimos ao longo de nossa etnografia que sempre um lançamento era seguido de outro. Tem sido cada vez mais comum os discos "vazarem" na internet, ou seja, as músicas são 
digitalizadas e disponibilizadas em algum nó da rede antes mesmo do disco físico começar a ser vendido. Sobre o Passo Torto, por exemplo, Rômulo Fróes publicou um parágrafo sobre o vazamento do disco no Facebook.

"O site ainda estava sendo desenhado, assim como toda a arte do disco novo do Passo Torto, pelo grande Julio Dui! Ele ainda não está pronto e estávamos testando o link para o download. Mas a internet não tem tempo para testes e vazou espetacularmente o disco novo! Que bom que ele tenha despertado esse interesse! Então desde ontem está lançado oficialmente o Passo Elétrico! Muito orgulhoso por mais esse trampo ao lado dos parceiros Kiko Dinucci, Marcelo Cabral e Rodrigo Campos! Vai lá!” (Postagem de Rômulo Fróes no facebook, dia 21 de maio de 2013).

Uma vez na rede, um disco começa a se espalhar através de aliados virtuosos como blogs, aliados que muitas vezes o artista nem pode imaginar. Esses aliados amplificam e espalham a agência desses objetos/sujeitos musicais através da "sociedade em rede" (CASTELLS, 2005). Essa sociedade, como bem nota Rômulo Fróes, é veloz, "não têm tempo para testes." O disco virtual no ciberespaço possibilita essa rápida circulação da informação musical digitalizada. Até mesmo a expressão "vazar" nos revela o quanto o virtual é líquido e efêmero. As metáforas aquáticas e gasosas são amplamente utilizadas para se pensar a cibercultura. Lévy fala o tempo todo no oceano informacional que caracteriza o universo digital. $\mathrm{O}$ disco virtual vaza porque ele pode se atualizar em qualquer um dos nós da rede através de diversos tipos de conexão.

A cibercultura pode ser pensada como essa nova maneira de lidar com a comunicação mediada pelos computadores e com o oceano de informações que circula no ciberespaço. No ciberespaço tudo está em constante mutação, tudo carrega uma certa dose de efemeridade. As novas tecnologias de uso diário também se desenvolvem rapidamente. A cada ano as grandes empresas do ramo, como a Apple, renovam seus produtos trazendo sempre novas características para os usuários. Gell (1999) nos fala do encantamento da tecnologia utilizando exemplos variados - desde de sociedades na melanésia até suas experiências pessoais em exposições ocidentais - esse encantamento é exacerbado na sociedade em rede. Qual pessoa adulta que tenha nascido no século XX não se maravilhou na primeira vez que mexeu num telefone celular, ou num Laptop? O encantamento da tecnologia é o sentimento que experimentamos quando nos deparamos com um objeto e não conseguimos sequer 
imaginar como ele foi produzido. Para Gell, todos os tipos de objeto, inclusive as obras de arte, são vistos como resultados de processos técnicos.

"Eu considero as várias artes - pintura, escultura, música, poesia, ficção, e assim por diante - como componentes de um vasto e frequentemente irreconhecível sistema técnico, essencial para a reprodução das sociedades humanas, o qual eu chamarei de tecnologia do encantamento." (GELL, 1999:43).

Como já colocamos especialmente ao longo do segundo capítulo, a antropologia não deveria olhar para a arte buscando julgamentos ou avaliações estéticas. O que Gell propõe é que seria mais profícuo pensarmos na arte como um sistema técnico de encantamento, e no encantamento como um termo abrangente que expressa a "aquiescência" geral de indivíduos inseridos em "redes de intencionalidades" das quais dependem qualquer sociedade.

"O encantamento da tecnologia é o poder que processos técnicos tem de lançar um feitiço sobre nós de modo que vejamos o mundo real de uma forma encantada. Arte, como um tipo separado de atividade técnica, só leva mais longe através de uma espécie de involução, o encantamento que é imanente a todos os tipos de atividade técnica." (GELL, Ibidem:43).

Na comunicação mediada por computadores, estamos imersos num mundo tecnológico que nos encanta a cada novo uso por parte das comunidades virtuais. Os discos virtuais "lançam um feitiço" sobre os ciberouvintes que podem divagar a respeito das dificuldades técnicas por trás da produção e disponibilização daquele conjunto específico de músicas. O artista é um técnico e vice versa, retomando aqui a ideia apresentada no primeiro capítulo. No nosso caso, estamos lidando com artistas-técnicos especializados da gravação de discos. Quando esses discos são digitalizados e disponibilizados na internet produzem um curto circuito entre o artista e o público pois podem viajar pelo globo através do ciberespaço.

"A Internet permite que artistas pulem os intermediários e alcancem diretamente os fãs. Aficionados por música podem encontrar e explorar novas categorias de música com mais facilidade. Isso significa que artistas menores e regionais ou músicos de nicho (digamos um acordeonista de zydeco) podem criar bases de fãs globais e distribuídas, o que resultará em mais oportunidades de receita." (The Berkman Center for Internet \& Society at Harvard University em edição especial da Revista do Auditório, 2011:43)

Vimos que as redes sociais são formadas por dois elementos fundamentais atores (nós) e conexões (arestas). Cada interação de Tatá, Rodrigo ou Kiko na internet vai constituindo uma rede social por onde seus discos circulam e agem. Eles são atores, seus endereços eletrônicos 
são os nós onde eles se presentificam. Seus discos são os agentes musicais que os constituem enquanto artistas na medida em que circulam, que "vazam", que se espalham. Rodrigo Campos produziu o Bahia Fantástica e o Bahia Fantástica produziu Rodrigo Campos enquanto artista, ao tecer associações virtuosas e virtuais com outros atores a agentes da rede. Um blog, um jornalista, um comentário de fã sobre o disco ou sobre uma música são as reações à agência online de sua obra que vão construindo sua imagem de artista, uma imagem reconhecida por um coletivo de entidades e seres. As tecnologias digitais de gravação geraram um curto-circuito entre arte e técnica. As tecnologias digitais de comunicação geraram um curto-circuito entre artistas e público.

"Com a CMC, a comunicação "de um para muitos", oriunda das mídias convencionais, como as mídias impressas, televisivas e radiofônicas, dá espaço a comunicação "de muitos para muitos", fenômeno esse que reúne os elementos essenciais da nova sociedade da informação, tais como:

- interatividade, dando voz e poder de atuar e interferir a quem jamais teve anteriormente, favorecendo, inclusive, a dialética;

- colaboração, trazendo à tona a necessidade e a importância das intra e inter-relações sociais;

- nova organização do espaço (fluxos), que independe de aproximação física, e do tempo, que permite conexões simultâneas, viabilizando comunicação instantâneas e conversas em tempo real.” (FERRAZ, et al., 2009:19-20)

As novas tecnologias fornecem condições para um novo tipo de produção fonográfica e um novo tipo de divulgação que produzem um novo tipo de artista. "Dizer que a técnica condiciona significa dizer que abre algumas possibilidades, que algumas opções culturais ou sociais não poderiam ser pensadas a sério sem sua presença.” (LÉVY, 1999:26). A autonomia e verticalização do trabalho em diversas áreas se torna característica marcante desses músicos que vivenciaram em seu percurso as principais transformações que tentamos expor ao longo deste capítulo. De um período onde os discos eram artefatos físicos caros e para poucos, chegamos a um período em que o disco é um artefato ao alcance da maioria dos músicos e que se desdobra em suportes físicos e em arquivos digitais facilmente manipuláveis. Os músicos que gravam discos e utilizam o ciberespaço para divulgá-los estão consolidando novas práticas criativas e comunicacionais que encontram eco na forma como o trabalho em geral está se consolidando na sociedade em rede. As hierarquias verticais estão sendo suplantadas pelo cooperativismo horizontal. O fazer musical contemporâneo de grupos que trabalham com a produção de discos não fica de fora dessas profundas transformações. 


\section{CONSIDERAÇÕES FINAIS}

Esta narrativa buscou conectar discos de vinil, CDs, pendrives, músicos, fazeres musicais, público, estúdios, computadores, softwares, notícias de jornal, internet, instrumentos musicais, microfones, pré-amplificadores, relações de amizade, relações de família, cibercultura, leis de incentivo à cultura, espaços de show entre outras coisas para descrever da melhor maneira possível um determinado universo musical. Identificamos dois curtoscircuitos fundamentais desse universo - um entre arte e técnica e outro entre artistas e público - e uma reconfiguração do disco como sujeito/objeto musical.

Vimos no primeiro capítulo, como um disco é construído através de dinâmicas coletivas de arranjo num contexto de proliferação de estúdios de pequeno e de médio porte na cidade de São Paulo. Essas dinâmicas coletivas de arranjo são caracterizadas por dois tipos de discurso - verbal e não-verbal - e por uma tradição musical que pode ser chamada de oral-aural (aprendizado e memorização musical dos arranjos feitos de ouvido, escutar como uma atitude fundamental na hora de iniciar a produção de uma canção). A partir do barateamento das tecnologias de gravação de áudio, e do desenvolvimento de interfaces gráficas de computador fáceis de serem operadas por não-especialistas, o fazer musical de um grupo sonoro se transforma trazendo à tona um novo perfil de músico - o músico que é um mediador eficaz entre arte e técnica, chamado também de produtor musical. As fronteiras entre instrumentistas, intérpretes, compositores, técnicos de estúdio são aqui mais fluidas, todos se deixam contaminar um pouco pela atividade do outro. Ao final de uma gravação todos são um pouco artistas, todos são um pouco técnicos, todos gravaram e foram gravados pelo disco. $\mathrm{O}$ disco troca propriedades com cada envolvido, deixa marcas, ensina. Vimos como a produção fonográfica desses jovens artistas se caracteriza por um curto-circuito entre arte e técnica que desemboca numa enorme quantidade de discos produzidos nos últimos anos.

No segundo capítulo, pudemos acompanhar como esses discos já gravados começam a agir na construção dos artistas. Reconfiguramos o lugar social dos discos detalhando as redes de relações e interações que envolvem artistas e público, sendo que todos os termos dessa rede assumem posições dinâmicas, trocando propriedades entre si e atuando um sobre o outro. Vimos, para lembrar um exemplo, como Rodrigo Campos se torna outra categoria de músico aos olhos do público (incluindo aqui sua família) e aos olhos de si mesmo, uma transformação 
causada pelo seu primeiro disco São Mateus Não É um Lugar Assim Tão Longe e por todos os agentes causais que trocam propriedades com essa obra. As notícias de jornais reconhecendo o valor artístico do disco foram fundamentais para mudar a visão que o pai Isac tinha da carreira do filho. A partir do momento em que o disco é elogiado num jornal de grande circulação, uma série de transformações virtuosas acontece em termos de reconhecimento público de Rodrigo Campos. Tentamos demonstrar através desses exemplos etnográficos que o disco é uma engrenagem fundamental desse maquinário social de construção de artistas no mundo da música popular - vimos que eles são fundamentais para a constituição de pessoas artístico-musicais construindo a autoconsciência sobre sua própria obra. Ao mesmo tempo que individualizam a obra de um compositor eles a coletivizam, ou seja, tornam a pessoa distribuível na forma disco. Essa forma não se transformou mesmo com o curto-circuito entre arte e técnica; a forma álbum é perpetuada por essa geração de artistas.

Realizamos uma experimentação musical-sociológica com conceitos de Gell criados para o mundo das artes plásticas. O disco emergiu como indexe, os compositores como artistas e o público como recipiente. Os artistas causam e são causados pelos discos; eles fazem os discos e os discos os fazem na medida em que circulam e são reconhecidos coletivamente. Esse reconhecimento coletivo é essencial para um indivíduo passar para a categoria de artista, não adianta o comunicante da obra dizer "eu sou um artista", ele tem que ser reconhecido enquanto tal. Como indica Antônio Cândido ([1965] 2006), a feitura de uma obra de arte está ligada a sua repercussão junto ao público. Poderíamos dizer também que a feitura do artista enquanto tal está diretamente ligada a essa repercussão de sua obra. Uma das medidas da repercussão da obra de um artista no caso da música é o "Prêmio da Música Brasileira", maior e mais importante premiação da música brasileira com edições anuais. O nome de Rodrigo Campos figurava na última edição desse prêmio dentre nomes consagrados da nossa música como Moraes Moreira, Cauby Peixoto e Elba Ramalho. Rodrigo Campos ganhou em Junho de 2013 com seu Bahia Fantástica o prêmio na categoria "revelação." O disco "revela" o artista.

"Como se vê, não convém separar a repercussão da obra da sua feitura, pois, sociologicamente ao menos, ela só está acabada no momento em que repercute e atua, porque, sociologicamente, a arte é um sistema simbólico de comunicação inter-humana, e como tal interessa ao sociólogo. Ora, todo processo de comunicação pressupõe um comunicante, no caso o artista; um comunicado, ou seja, a obra; um comunicando, que é o público a que se dirige; graças a isso define-se o quarto elemento do processo, isto é, o seu efeito." (CÂNDIDO, [1965] 2006: 31). 
No terceiro capítulo, realizamos uma breve discussão sobre como estudiosos da cibercultura, da sociedade em rede e das redes sociais estão analisando as novas realidades sócio-técnicas enfatizando sua influência nas práticas comunicativas. Castells (2005) sugere duas ideias que parecem se encaixar adequadamente ao que encontramos entre músicos - o "trabalho autoprogramável" e a "comunicação de massa auto-dirigida." Essa série de dois prefixos "auto" nessas expressões não é gratuita; revela a enorme autonomia que essas novas tecnologias geram em diversas esferas da vida e áreas de trabalho, transformando diversas profissões e empresas. Acompanhamos como os discos e artistas atuam no ciberespaço e como se dão as interações entre autor-obra-público num ambiente online, e o como se gera o quarto elemento do processo - o efeito. A internet e as redes sociais possibilitaram uma comunicação direta entre artistas e público caracterizando o segundo curto-circuito observado, o curto-circuito comunicacional entre artistas e público.

O caso do Tribunal do Feicebuqui evidenciou esse curto-circuito e exemplificou muito bem a agência de não-humanos. Tom Zé se vê criticado pelos fãs respondendo rápida e diretamente aos mesmos através de um disco disponibilizado digitalmente. Coincidentemente, o consagrado compositor convidou dois de nossos interlocutores aqui, Kiko Dinucci e Tatá Aeroplano, para participarem dessa resposta em forma de disco. O disco, a internet, o público, o Facebook são todos sujeitos de ações nessa história. Os usos e discursos supervalorizam o ciberespaço como local privilegiado de divulgação dos trabalhos artísticos. Entretanto, não basta ter um disco e disponibilizá-lo na internet para se ter imediatamente reconhecimento de público e passar a uma nova categoria de artista. Apesar de focalizar a reconfiguração do disco enquanto obra de arte mostrando que ele é um agente fundamental, ele sozinho não faz nada, não explica nada. O reconhecimento dos jornalistas em matérias de grandes jornais e revistas ainda é fundamental. Se a televisão também reconhecer o valor de um disco e de um artista, melhor ainda. Grandes veículos de comunicação ainda são muito importantes, mesmo que o discurso nativo não enfatize isso. Poderíamos citar um centena de discos produzidos nesses últimos anos que provavelmente não agenciaram grandes transformações na vida das pessoas que os produziram. Um disco que não ganha reconhecimento público não grava um artista. É como um artigo científico que não é aceito por seus pares, que não consegue arregimentar aliados, trazendo mais uma vez aqui a discussão de Latour (2000). Nesta etnografia, a Folha de São Paulo, o Estado de São Paulo, a Veja São Paulo e seus respectivos sites na internet são aliados virtuosos, são agentes causais fundamentais. Tanto é que muitos 
artistas gastam uma quantia considerável com a chamada assessoria de imprensa para que seus discos e nomes circulem pela comunidade de jornalistas que são formadores de opinião. Os releases utilizados para apresentar um trabalho a um possível contratante de shows como o SESC, trazem as matérias de jornal e revista onde o artista foi citado como uma forma de atestar sua qualidade.

Em conversas informais com produtores de shows (os responsáveis pela venda dos shows desses artistas) fui informado que sair em uma matéria de jornal é fundamental para os programadores dos SESCs avaliarem os artistas, por exemplo. Os três nomes que reunimos nessa dissertação souberam, entre outras coisas, conectar seus discos aos agentes midiáticos certos, ou seja, souberam transformar os discos em agentes eficazes para promoção de seus nomes junto aos meios de comunicação da mídia impressa de São Paulo. Não é só o disco que age, mas sem o disco fica praticamente impossivel agir nessa rede generativa de artistas novos e que movimenta a cena musical autônoma de São Paulo. Essa ideia de que sem o disco a ação generativa de artistas se torna inexistente ou ineficaz nos ajuda a finalmente responder à nossa pergunta: por que eles ainda gravam discos? Os artistas gravam os discos porque os discos gravam os artistas. Por que os discos gravam os artistas? Porque eles são agentes causais fundamentais que ao trocarem propriedades com outros agentes (jornalistas, internet, familiares, ouvintes, músicos etc.) tornam possível que compositores como Tatá, Rodrigo e Kiko perpetuem sua arte, amplifiquem seu público e divulguem seus nomes. Eles (os discos) são pessoas-artístico-musicais, são processos criativos, são toda rede de associações tecida dentro dos estúdios entre humanos e não-humanos, são cartões de visita, são vitrine, são um conjunto de canções que individualiza a obra de um compositor, são a pessoa desse compositor se distribuindo e se multiplicando através do ciberespaço, e são, ainda, em alguma fase de sua trajetória social, mercadorias.

\section{Nota sobre a ideia de música independente}

A partir de todas estas transformações que observamos no mundo da música popular -e que já são percebidas por diversos estudiosos, especialmente da área da comunicação - observamos em todo país, o fortalecimento das chamadas cenas independentes de música. A ideia de independente está fortemente ligada a essa fase recente em que as grandes indústrias fonográficas perdem poder econômico, em que pequenos selos ganham espaço, novos estúdios viabilizam a produção de discos de pequenas bandas e jovens compositores. 
Entretanto, como aponta Dias (2008), os independentes não são novidade. Ela cita uma primeira gravação de Carmen Miranda em 1929, no pequeno selo Brunswick, como um possível marco da música independente no Brasil. Segue discutindo as experiências da Vanguarda Paulista nos anos 80, as experiências de Pena Schmidt nos anos 90 com o selo Tinitus, e um pouco da história de Luís Calanca dono da Baratos e Afins. Tudo o que apontamos ao longo de nossa pesquisa sobre como os discos se tornaram peças chaves no fazer musical contemporâneo - a partir de um curto-circuito entre arte e técnica e outro entre artista e público - está de certa forma ligado ao que se costuma chamar de música independente, ou indie.

O que une essa massa de novos músicos é acima de tudo um acesso facilitado a um conjunto de mediadores que antes eram monopólio de grandes conglomerados. Eles (os músicos de hoje) produzem os mais variados estilos e gêneros musicais, porém todos conseguem viabilizar seus discos de forma independente. Mas vale deixar claro que esse independente é em relação às grandes companhias como Sony, Warner ou Universal Music. Esse independente não é um independente total e absoluto. Ninguém é totalmente independente de ninguém. Acabamos de colocar alguns parágrafos acima que um disco sozinho não faz nada. Os independentes dependem de muitas coisas, entre elas, dependem dos outros independentes. Dependem, por exemplo, dos organizadores de festivais independentes, dependem da internet, dependem dos donos de pequenos e médios estúdios, dependem de editais públicos de incentivo à cultura, dependem de sites de financiamento coletivo, dependem de jornalistas e formadores de opinião, dependem de curadores e programadores de casas de show ${ }^{96}$. Conforme o século XXI avança e o século XX fica mais distante (com suas conjunturas sociais, técnicas e econômicas específicas), menos sentido fará essa ideia de independente atrelada a uma realidade que vemos totalmente transformada. O termo autônomo me parece ser mais adequado para expressar a situação dessa nova geração de músicos que produz num mundo onde as grandes indústrias (que ainda existem e ainda lançam grandes hits no mercado) convivem com esse universo formado por uma classe média de músicos autônomos ${ }^{97}$.

\footnotetext{
${ }^{96}$ Concordo com o próprio Luís Calanca, citado por Dias (2008), que afirmou não gostar do termo independente.

97 "Música Alternativa" é outra expressão comum nesse meio. Me parece melhor do que independente para descrever aspectos do grupo sonoro que estudamos. Tatá Aeroplano, Kiko Dinucci, Rodrigo Campos e muitos outros são criadores de estratégias alternativas para se viver de música.
} 
Alguns jornalistas e críticos musicais falam em "Nova MPB" ou "Neo MPB" para tentar classificar essa nova geração do mundo musical. Porém, a variedade de estilos e gêneros musicais que eles gravam em seus discos e tocam em seus shows é tão ampla que uma classificação estilística perde o sentido. O jeito que fazem música, a maneira de produção de discos, a forma como criam arranjos coletivamente são socialmente mais significativos e unem diversos estilos e gêneros diferentes. O próprio Kiko Dinucci é capaz de fazer um show acústico que remeta diretamente ao samba paulista, e em seguida fazer um show eletrificado e pesado muito mais ligado ao punk rock do que ao samba. Rodrigo Campos gravou um $1^{\circ}$ disco calcado no samba, onde predominavam instrumentos acústicos, para lançar em seguida um álbum totalmente diferente, tanto nos arranjos e na instrumentação, quanto no estilo de composição. O que os une de alguma forma é a autonomia com a qual criam suas obras de arte musicais. Esses artistas autônomos já passaram pelo underground, já tocaram em festivais sem ganhar cachês, fizeram e/ou fazem parte do que é considerado um mercado de música independente, mas não se limitam a ele. Já fazem parte de uma espécie de classe média da música - não são artistas do mainstream, mas já superaram os limites da cena independente. Eles não estão dentro, porém não estão totalmente nas "bordas do mainstream" (HERSHMANN, 2011).

\begin{abstract}
"Artistas pequenos, a nova classe media da música, estão usando plataformas de rede social como alavanca para alcançar uma base de fãs global. Por meio de ferramentas de distribuição faça-você-mesmo, artistas podem eliminar os intermediários e distribuir música diretamente para os fãs, ganhando mais em royalties do que ganhariam sob os tradicionais contratos assinados com grandes gravadoras e editoras durante o auge do compact disc. Alguns artistas até angariam fundos diretamente com os fãs para bancar a produção de música inédita." ("The Berkman Center for Internet \& Society at Harvard University” In: Repensando Música. MACHADO; NOLASCO, 2011:12).
\end{abstract}

Como me disse Juliano Polimeno, dono do extinto selo PHONOBASE, responsável pelo lançamento de dois discos do Cérebro Eletrônico: "Se alguém me pergunta se é Indie ou Major eu falo Major, precisa parar com esse negócio de Indie senão a gente vai ser sempre pequeno!" Indie é o termo em inglês, abreviado, para independente. Major é o termo em inglês para grande gravadora. Sites como o MySpace.com, permitem que o artista classifique seu trabalho como Indie ou Major. Juliano Polimeno recomenda que o artista sempre se identifique como Major.

A cantora Tulipa Ruiz é um exemplo emblemático de artista autônomo que transcendeu o 
underground sem estar ligada a nenhuma grande gravadora. Ela lançou seu primeiro disco, Efêmera, em 2010, alcançando rapidamente sucesso de crítica e de público. Em 2011, foi aprovada no edital da empresa "Natura" que patrocina anualmente a gravação de discos e a circulação de shows, através do qual gravou seu $2^{\circ}$ disco, Tudo Tanto. Em 2012, uma de suas músicas, Só Sei Dançar Com Você, entrou em uma novela da rede Globo. Faz sentido falar que Tulipa Ruiz é uma artista independente? Ela não é totalmente independente; permanece autônoma, mas aceita de bom grado o apoio de empresas, a divulgação na TV e qualquer parceria que a beneficie na divulgação de seu trabalho. Num certo sentido, ela 'depende' dessas parcerias para criar sua música com uma estrutura cada vez melhor. Porém, ela possui autonomia artística sobre seus discos. O produtor dos dois discos é seu irmão Gustavo Ruiz. Seu pai, Luiz Chagas, toca guitarra na banda. Trata-se de uma banda familiar que alcançou um sucesso maior do que muitos artistas ligados à gravadoras. Assim como Kiko Dinucci, Tulipa Ruiz é artista plástica. A capa de Efêmera foi desenhada por ela. A distribuição desse 1o. disco em lojas foi feita pela própria Tulipa, fato que poucos de seus novos fãs conhecem. Semanalmente, ela contabilizava os discos vendidos, os pedidos novos e organizava pessoalmente a distribuição. Tatá Aeroplano, amigo de Tulipa Ruiz de longa data, me passou essa informação numa conversa a respeito de como os artistas precisam se responsabilizar sobre todas as etapas de seu trabalho. Tatá e Tulipa são grandes amigos.

Tatá Aeroplano muitas vezes passa o dia no computador trabalhando na divulgação de seu novo disco. Enviando e-mails, pesquisando editais, ouvindo novos artistas, atualizando seu site, escrevendo projetos etc. Isso faz parte de seu fazer musical tanto quanto tocar seu violão e cantar. Somente dessa forma, ele pode se tornar um artista com autonomia criativa; um artista que canta suas próprias composições, divulgando a maneira como enxerga sua sociedade, a maneira como experimenta suas relações, expressando suas vivências e experiências afetivas com o mundo.

\section{Desafios À Vista}

Chegamos às linhas finais desta dissertação com uma sensação de que aconteceram muitas transformações positivas para essa camada média de músicos. Entretanto, mesmo com todos pontos positivos levantados a partir desta etnografia, os membros desse grupo sonoro de artistas do disco enfrentam instabilidades financeiras e desafios cotidianos que tornam o viver de música autoral uma batalha constante. Eles não têm garantia alguma de quanto dinheiro 
ganharão a cada mês. São trabalhadores autônomos que vão se desdobrando em múltiplas atividades e funções para viabilizarem suas vidas, para tentarem se manter sempre com alguma fonte de renda e para continuarem criando. Kiko Dinucci e Rodrigo Campos eventualmente realizam trabalhos como músicos que acompanham outros artistas. Tatá Aeroplano trabalha como DJ e faz trilhas para cinema. Os shows ao vivo são fundamentais sendo que os SESCs são os melhores locais em São Paulo em termos de infraestrutura técnica e de cachês. Entretanto, não existe espaço suficiente para todo mundo que tem disco tocar ao vivo. Muitos artistas encontram grandes dificuldades para lançarem os discos que gravaram com tanto cuidado e dedicação. Existem mais discos do que lugares para tocar. Mesmo o show de um disco premiado como o Bahia Fantástica encontrou dificuldades para circular nesse primeiro ano desde o lançamento oficial. Maurício Tagliari, um dos donos da YB music, gravadora que lançou Bahia Fantástica afirma que essa geração de músicos enfrenta grandes dificuldades:

"O mais gritante para mim é que o cidadão pode ser um grande músico, compositor e cantor. Ele sai nos jornais, é comentado por um certo círculo, mas não consegue passar na peneira se não chegar nos velhos meios (TV globo, rádio jabazeira etc). Não há casas médias para se ver shows, só bares e mega casas, então, ou se é muito popular (sertanejo universitário?) e ganha muita grana ou você rala tocando para meia dúzia por merreca. Não está fácil para ninguém. O problema hoje é de distribuição.” (Entrevista com Mauricio Tagliari, dia 20/03/2013).

Essa fala de Mauricio Tagliari é, de certa forma, uma ducha de água fria em todo otimismo que emanou dos discursos dos nossos interlocutores. Mesmo com a internet, Tagliari levanta a ideia de que sem os meios tradicionais de divulgação (TV e Rádio) esses artistas não conseguirão ultrapassar certos limites. Como já afirmei antes, estamos diante de dois pesos e duas medidas. O mainstream ainda existe e está distante de nossos três interlocutores principais. Ao menos, eles seguem produzindo discos de qualidade e que se tornam peças fundamentais em suas carreiras. Um dos desafios é como amplificar ainda mais o alcance dessa criação musical intensa que apesar de encontrar nas redes sociais na internet um forte aliado, ainda encontra dificuldades para se sustentar financeiramente. $\mathrm{O}$ curto-circuito entre arte e técnica promoveu uma avalanche de lançamentos de discos nos últimos anos. Porém, somente alguns vão conseguir fechar o ciclo produtivo lançando seus discos ao vivo em shows bem remunerados. Creio que muitos músicos que se aventuram no lançamento de discos de composições próprias vão ficar somente no primeiro lançamento. Um grande desafio dessa geração será lidar com essa super oferta de discos num momento em que as 
principais fontes de renda são os shows ao vivo. Nós acabamos contando nessa dissertação, a história de pessoas que estão conseguindo se manter no mercado médio da música. São casos de discos que encontraram uma boa reverberação pública transformando essas pessoas em artistas, transformando esses músicos em outra categoria de músicos. Seria necessário outra pesquisa, outra etnografia para contar a história dos inúmeros casos de jovens compositores que lançam discos e não conseguem se estruturar como artistas. Casos em que muitas vezes somente o primeiro disco é lançado e por não ser absorvido por nenhum público morre na praia. 


\section{GLOSSÁRIO:}

base - Costuma-se chamar de base de uma música a massa sonora formada por bateria, baixo e algum instrumento harmônico como guitarra e/ou piano. As bases são gravadas ao vivo sempre que possível.

cabeça - Início de cada compasso.

hit - Um música com forte apelo comercial que alcança sucesso de público. Um música que cai no gosto popular.

home studio - Estúdio caseiro composto por equipamentos mais baratos e simples que podem ser colocados e instalados dentro de uma sala ou quarto.

intro - Introdução de um arranjo musical e/ou de uma canção.

mainstream - A tradução literal do inglês seria algo do tipo "corrente principal". No caso da música designa o primeiro escalão de artistas com sucesso comercial.

menorizar - Tornar um acorde menor.

pé duro - Acorde maior sem sétimas e nonas, somente tríade básica.

picotado elou picadinho - Notas tocadas separadas, som interrompido entre uma e outra.

resetar - Reiniciar um computador ou um software.

recado - Pronto para gravar, canais ativos para iniciar a gravação.

riffs - Pequeno trecho melódico que se repete numa música servindo de base.

take - uma sessão de gravação de um ou mais instrumentos ao vivo. Por exemplo, o baterista que acabou de gravar uma música e gostou da sua performance pode solicitar ao técnico de gravação; "Guarda esse take que ficou bom!"

talo - Volume sonoro intenso. 


\section{REFERÊNCIAS BIBLIOGRÁFICAS:}

- ALMADA, Carlos. Arranjo. Campinas, SP: Editora da Unicamp, 2010.

- APPADURAI, Arjun. “Introdução: Mercadorias e a Política de Valor” in A Vida Social das Coisas: as mercadorias sob uma perspectiva cultural. Niterói: Editora da Universidade Federal Fluminense, 2008.

- BENJAMIN, Walter. “A Capacidade Mimética.” In: Humanismo e Comunicação de Massa. Rio de Janeiro: Tempo Brasileiro: 1970.

. “A Obra de Arte na Época de suas Técnicas de Reprodução.”

In: Os Pensadores - Benjamin, Adorno, Horkheimer e Habermas. São Paulo: Abril Cultural, 1980.

- BLACKING, John. "Música, Cultura e Experiência." In: Cadernos de Campo, v16, n16, São Paulo, 2007.

- CÂNDIDO, Antônio. Literatura e Sociedade. Rio de Janeiro: 2006.

- CAMPOS, Luís Melo. “Modos de Relação com a Música”. In: Sociologia, Problemas e Práticas, n.o 53, 2007, pp. 91-115.

- CASTEllS, Manuel e CARDOSO, Gustavo, eds. The Network Society: From Knowledge to Polic.y. Washington, DC: Johns Hopkins Center for Transatlantic Relations, 2005.

- CEZAR, Lilian Sagio. "Filme Etnográfico por David MacDougall” in Cadernos de Campo, v16, n16, São Paulo, 2007.

- CHAGAS, Jeferson e PEREIRA de SÁ, Simone. "Discografias: Mediações Musicais em uma Discoteca Coletiva." In: Dez Anos a Mil: Mídia e Música Popular Massiva em Tempos de Internet. Janotti Jr, Jeder Silveira; Lima, Tatiana Rodrigues; Pires, Victor de Almeida Nobre (orgs.) - Porto Alegre: Simplíssimo, 2011. 
- CIRINO, Giovanni. Narrativas Musicais - performance e experiência na música popular instrumental brasileira. São Paulo: Editora Annablume, Fapesp, 2009.

- DENORA, Tia. Music in Action: Selected essays in sonic ecology. Inglaterra: Ashgate: 2011.

- DIAS, Marcia Tosta. "Indústria Fonográfica - a Reinvenção de um Negócio.” In Economia da Arte e da Cultura. Bolaño, Golin e Brittos (orgs.). São Paulo: Itaú Cultural, 2010.

- Os Donos da Voz - indústria fonográfica brasileira e mundialização da cultura. São Paulo: Boitempo, 2008.

."Quando O Todo Era Mais Do Que A Soma Das Partes: Álbuns, Singles e os Rumos da Música Gravada." In Revista Observatório Itaú Cultural, no 13 (set 2012). São Paulo: Itaú Cultural: 2012.

- DOMINGUES, Diana. “Introdução: Humanização das tecnologias pela arte” in A Arte no Século XXI - A Humanização das Tecnologias. Diana Domingues (org.) São Paulo: Editora UNESP, 1997.

- EVANS-PRITCHARD, E. E. Os Nuer. São Paulo: Perspectiva, 1978.

- FELD, Steven. Sound and Sentiment: Birds, Weeping, Poetics, and Song in Kaluli expression. Pennsylvania: University of Pennsylvania Press, 1982.

."Sound structure as social structure". In Ethnomusicology, 28 (3),

1984.

- FERRAZ, Daniel, PELEGRINELLI, Denise, MATOS, Ecivaldo de Souza, HADDAD, Julio Cesar Mansur, MARTINS, Marta Terezinha Motta Campos, LA CORTE DOS SANTOS, Raquel, FARIA, Renata Prieto, MEDEIROS, Ricardo e MENDES, Tatiana Visnevski. Etnografia Virtual: Uma Tendência Para Pesquisa em Ambientes Virtuais de 
Aprendizagem e Prática. São Paulo: http://ccvap.futuro.usp.br/TMP UPLOAD/files/tcsecs1250008784833 nusp2511675.pdf, 2009.

- FERREIRA, Pedro Peixoto. Música Eletrônica e Xamanismo: técnicas contemporâneas do êxtase. Tese de doutorado em ciências sociais apresentada ao departamento de sociologia do Instituto de Filosofia e Ciiencias Humanas da Universidade Estadual de Campinas, IFCH/UNICAMP, Campinas - SP, 2006.

- GARCIA, Walter. Bim Bom: a contradição sem conflitos de João Gilberto. São Paulo: Paz e Terra, 1999.

- FINNEGAM, Ruth. "Senderos en la Vida Urbana." In: Las Culturas Musicales lecturas de etnomusicologia. Cruces, Francisco (org). Pgs. 437-474. Madrid: Editorial Trotta, 2008.

- GEERTZ, Clifford. “Art as a cultural system.” In: Local Knowledge - further essays in interpretative anthropology. New York: Basic Books, 1983.

- GELL, Alfred. Art and Agency: An Anthropological Theory. New York: Oxford University Press Inc., 1998.

. "The Thecnology of Enchantment and The Enchantment of Thecnology”. In The Art of Anthropology: Essays and Diagrams by Alfred Gell. London: Athlone, 1999.

. "Strathernograms, or, The Semiotics of Mixed Metaphors" In The Art of Anthropology: Essays and Diagrams by Alfred Gell. London: Athlone, 1999.

- HERSCHMANN, Micael. Nas Bordas e Fora do Mainstream Musical - novas tendências da música independente no início do século XXI. São Paulo: Estação das Letras e Cores, 2011. . Indústria da Música em Transição. São Paulo: Estação das Letras e Cores, 2010. 
- HIKIJI, Rose Satiko Gitirana. A Música e o Risco. São Paulo: EDUSP, 2006.

- HINE, Christine. Virtual Ethnography. Londres: SAGE Publications, 2000.

- KIM, Joon Ho. "Cibernética, Ciborgues e Ciberespaço: notas sobre as origens da cibernética e sua reinvenção cultural." In: Horizontes Antropológicos, ano 10, no. 21, Porto Alegre: 2004.

- Imagens da Cibercultura: As figurações do Ciberespaço e do ciborgue no cinema. Tese de Mestrado apresentada ao Programa de Pós-Graduação em Antropologia Social da USP. São Paulo: 2005.

- LATOUR, Bruno. "Give Me a Laboratory and I will Raise the World", in: K. KnorrCetina y M. Mulkay (eds.), Science Observed: Perspectives on the Social Study of Science, Londres: Sage, 1983, pp. 141-170.

. Ciência em Ação - como seguir cientistas e engenheiros sociedade afora. São Paulo: Editora UNESP, 2000. . A esperanca de Pandora: ensaios sobre a realidade dos estudos cientificos. Bauru - SP : EDUSC, 2001. . Reflexão Sobre o Culto Moderno dos Deuses Fe(i)tiches. Bauru - SP:

EDUSC, 2002. . Jamais Fomos Modernos. São Paulo: Editora 34, 2009.

- LÉVY, Pierre. Cibercultura. São Paulo: Editora 34, 1999.

- LIMA, Mariana Mont'Alverne Barreto. “O Específico Mercado Brasileiro de Música Gravada e a Nova Economia Mundial." In: Digitalização e Sociedade. 2o Encontro da ULEPICC (União Latina de Economia Política da Informação, da Comunicação e da Cultura). Bauru: 13 a 15 de Agosto de 2008. 
- LOMAX, Alan. “Estrutura de la cancion y estrutura social.” In: Las Culturas Musicales - lecturas de etnomusicologia. Cruces, Francisco (org). Pgs. 297-330. Madrid: Editorial Trotta, 2008.

- MACHADO, Cacá e NOLASCO, Juliana (orgs). Repensando Música. Edição especial da Revista Auditório. São Paulo: Livre Conteúdo e Cultura, 2011.

- MAGNANI, José Guilherme C.; TORRES, Lilian de Lucca (orgs.). Na Metrópole: Textos de Antropologia Urbana. São Paulo: EDUSP; FAPESP, 2008.

- MARRAS, Stélio. Recintos e evolução: capitulos de antropologia da ciência e da modernidade. Tese de doutoramento apresentada ao Departamento de Antropologia FFLCH/USP. São Paulo, 2009.

- MAUSS, Marcel. "Uma categoria do espírito humano: a noção de pessoa, a de "Eu”. In: Sociologia e Antropologia. São Paulo, Cosac\&Naify, 2005. . "As técnicas do corpo". In: Sociologia e Antropologia. São Paulo,

Cosac\&Naify, 2005.

- MERRIAM, Alan P. The Anthropology of Music. New York: Northwestern University Press, 1964.

- MIDANI, André. Música, Ídolos e Poder - do vinil ao download. Rio de Janeiro: Editora Nova Fronteira, 2008.

- MORELLI, Rita C. L. Indústria Fonográfica - Um Estudo Antropológico. Campinas SP : Editora Unicamp, 2009.

- NAVES, Santuza Cambraia. Canção Popular no Brasil. Rio de Janeiro: Civilização Brasileira, 2010.

- NETTL, Bruno. The Study of Ethnomusicology: twenty nine Issues and Concepts. Urbana and Chicago: University of Illinois Press, 1983. 
“Introduction: An Art Neglected in Scholarship" In: In The Course Of

Performance - studies in the world of musical improvisation. Chicago: Chigaco University Press, 1998.

- PERPÉTUO, Irineu e SILVEIRA, Sérgio Amadeu (orgs). O futuro da música depois da morte do CD. São Paulo: Momento Editorial, 2009.

- PIEDADE, Acácio Tadeu de Camargo. “A etnografia da música segundo Anthony Seeger: clareza epistemológica e integração das pesprspectivas musicológicas.” In: Cadernos de Campo. Vol 17. São Paulo: USP, Jan-Dez 2008, p. 233-236.

- OLIVEIRA PINTO, Tiago de. "Som e Música: Questões de uma Antropologia Sonora”. Revista de Antropologia, São Paulo: USP, v. 44, no 1, 2001.

- PRANDI, Reginaldo. Mitologia dos Orixás. São Paulo: Companhia das Letras, 2001.

- RECUERO, Raquel. Redes Sociais na Internet. Porto Alegre: Sulina, 2010.

- RIFIOTIS, Theophilus. "Desafios Contemporâneos para a Antropologia no Ciberespaço - o lugar da técnica.” In: Civitas. Porto Alegre: vol 12, no 3, pgs. 566-578, set-dez 2012.

- SAVAZONI, Rodrigo e COHN, Sérgio. Cultura Digital.br. Rio de Janeiro: Beco do Azougue, 2009.

- SEEGER, Anthony. "Etnografia da Música.” In: Cadernos de Campo, v17, n17, São Paulo, 2008. .Why Suyá Sing - A Musical Anthropology of an Amazonian People. Cambridge: Cambridge University Press, 2004.

- SHERMAN, Tom. “MACHINE R US...” In A Arte no Século XXI: A Humanização das Tecnologias. São Paulo: Editora UNESP, 1997.

- SCHOUTEN, André-Kees de Moraes e CIRINO, Giovanni. "Relendo Walter Benjamin: etnografia da música e inconsciente auditivo.” In: Cadernos de Campo, v13, n13, São Paulo, 2005. 
- TAPSCOTT, Don. A Hora da Geração Digital: como os jovens que cresceram usando a internet estão mudando tudo, das empresas aos governos. Rio de Janeiro: Agir Negócios, 2010.

- TARDE, Gabriel. "Monadologia e Sociologia" in Monadologia e sociologia e outros ensaios. São Paulo: Cosac Naify. ([1880] 2006).

- TATIT, Luiz. O Século da Canção. Ateliê Editorial, 2004. . O Cancionista - composição de canções no Brasil. São Paulo, EDUSP, 2002

- TAUSSIG, Michael. Mimesis and Alterity - A Particular History of the Senses. New York: Routledge, 1993.

- TINHORÃO, José Ramos. História Social da Música Popular Brasileira. São Paulo: Ed. 34, 1998. . As Origens da Canção Urbana. São Paulo: Ed. 34, 2011.

- ULHÔA, Martha Tupinambá de. "Nova História, Velhos Sons: Notas Para Ouvir e Pensar a Música Brasileira Popular. In: Debates v.1, n.1, Rio de Janeirop, 1997. -VIVEIROS DE CASTRO, Eduardo. "Floresta de Cristal: notas sobre a ontologia dos espíritos amazônicos.” in Cadernos de Campo v15 n14/15, São Paulo, 2006.

- WILSON, Samuel M. e PETERSON Leighton C. "The Anthropology of Online Communities" in Annual Reviews In Advance. Austin, Texas: 2002. 31: 449-67.

- WISNIK, José Miguel. O Som e o Sentido. São Paulo: Companhia das Letras, 2005. 


\section{REFERÊNCIAS FONOGRÁFICAS:}

\section{Banda Cérebro Eletrônico:}

- Onda Híbrida Ressonante, Reco Head, 2004.

- Pareço Moderno, Phonobase, 2008.

- Deus e o Diabo no Liquidificador, Phonobase, 2010.

\section{Tatá Aeroplano (disco solo):}

- Tatá Aeroplano, Independente, 2012.

\section{Rodrigo Campos (discos solo):}

- São Mateus Não É um Lugar Assim Tão Longe, Ambulante discos, 2009.

- Bahia Fantástica, YB, 2012.

\section{Kiko Dinucci (com suas parcerias):}

- Padê, Independente, 2007.

- Kiko Dinucci e o Bando Afromacarrônico - pastiche Nagô, Desmonta, 2008.

- Duo Moviola - O Retrato do Artista Quando Pede, Desmonta, 2008.

- Na Boca dos Outros, Desmonta, 2010.

- Metá-Metá, Desmonta, 2011.

- Metal-Metal, Desmonta, 2012.

\section{Passo Torto:}

- Passo Torto, YB, 2011.

- Passo Elétrico, YB, 2013. 
